\title{
WestVirginiaUniversity
}

THE RESEARCH REPOSITORY @ WVU

Graduate Theses, Dissertations, and Problem Reports

2014

\section{Economic and Monetary Union: An Unexplored Case of Federalism}

Alessandro Cagossi

West Virginia University

Follow this and additional works at: https://researchrepository.wvu.edu/etd

\section{Recommended Citation}

Cagossi, Alessandro, "Economic and Monetary Union: An Unexplored Case of Federalism" (2014).

Graduate Theses, Dissertations, and Problem Reports. 591.

https://researchrepository.wvu.edu/etd/591

This Dissertation is protected by copyright and/or related rights. It has been brought to you by the The Research Repository @ WVU with permission from the rights-holder(s). You are free to use this Dissertation in any way that is permitted by the copyright and related rights legislation that applies to your use. For other uses you must obtain permission from the rights-holder(s) directly, unless additional rights are indicated by a Creative Commons license in the record and/ or on the work itself. This Dissertation has been accepted for inclusion in WVU Graduate Theses, Dissertations, and Problem Reports collection by an authorized administrator of The Research Repository @ WVU.

For more information, please contact researchrepository@mail.wvu.edu. 


\title{
Economic and Monetary Union: an Unexplored Case of Federalism
}

\author{
by \\ Alessandro Cagossi \\ Dissertation Submitted to the College of Arts and Sciences \\ at West Virginia University \\ in Partial Fulfillment of the Requirements \\ for the Degree of \\ Doctor of Philosophy \\ in \\ Political Science
}

\author{
Donley T. Studlar, Ph.D. Chair \\ Robert Blobaum, Ph.D. \\ Robert D. Duval, PhD. \\ Joe D. Hagan, Ph.D. \\ Karleen A. West, Ph.D.
}
Department of Political Science
Morgantown, West Virginia
2014

Keywords: European Union, Economic and Monetary Union, Federalism

Copyright 2014 Alessandro Cagossi 


\begin{abstract}
This dissertation is intended to shows how federalism can be a useful theoretical tool to conceptualize the overall evolution of Economic and Monetary Union (EMU) from its inception to the current attempts (as of April 2014) to tackle the financial crisis that has affected the Eurozone since 2010. The topic is important because no detailed studies are yet available using a federalist focus on EMU. This research, therefore, is aimed to fill a gap in the literature currently approaching economic and monetary integration.

The dissertation draws on the assumptions found in the current mainstream literature on European integration. In this regard, monetary union has been already analyzed from different theoretical perspectives, such as neo-functionalism, Multi-Level Governance, Europeanization, intergovernmentalism, and domestic politics theory. Such theories sometimes conflict with each other and sometimes partially overlap, but all have some weaknesses. On the contrary, I believe that applying federalism to EMU encompasses other contending approaches in one theoretical focus, providing a parsimonious, structural, and multilayered explanation able to elucidate the overall EMU evolution.

Analyzing "how" EMU has been politically developed, EMU policies have been implemented, and EMU polity has changed over the decades, my main hypothesis is that the incremental writing of the "rules of the game" has been made possible by the European Council through horizontal federalism ("the method"). Horizontal federalism has almost always strengthened EC/EU institutions and targeted the vertical centralization of economic and monetary affairs ("the outcome"). As such, horizontal and vertical federalism elicited an incremental and steady federalization of EMU ("the process") that is lasting from the 1950 s to nowadays.

Concerning the methodology, in order to demonstrate the validity of my hypothesis, I utilize two interconnected qualitative methods: process tracing is the basis of the narration of the empirical process pertaining to the EMU, while structured focused comparison will allow me to compare the various integration theories identified above, including federalism, using EMU as the case study. These methods follow primary research consisting of a collection of original data, analysis of official documents and original reports on EMU, and unstructured interviews were conducted with technocrats, scholars, diplomats, and policy-makers.
\end{abstract}




\section{Table of Contents}

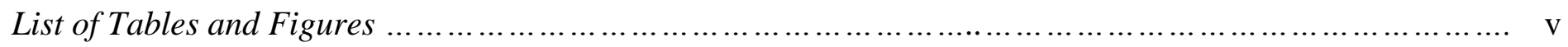

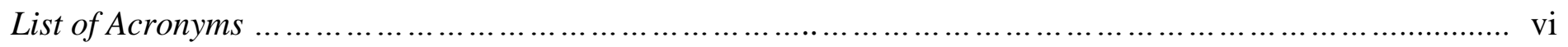

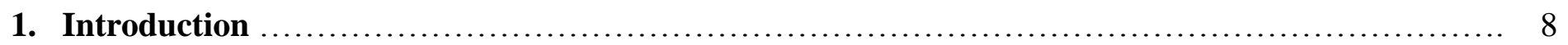

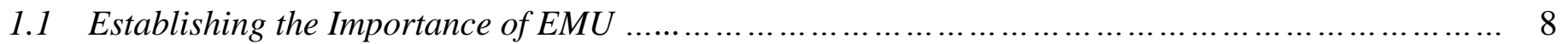

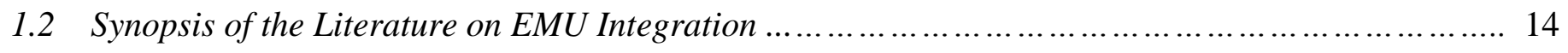

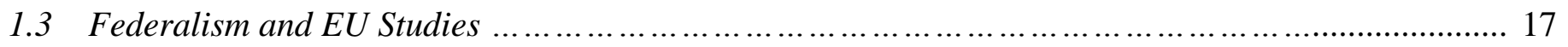

1.4 Research Questions, Hypotheses and Methods .................................................. 22

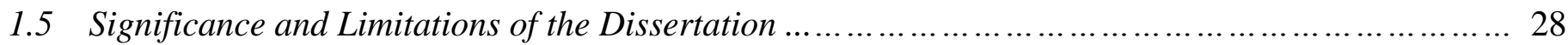

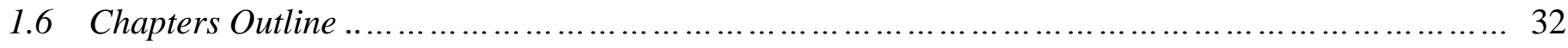

2. Methodological Note: Process Tracing and Structured Focused Comparison .................... 35

2.1 The Deductive Nature of the Research Design ................................................... 35

2.2 The Evolution of EMU through Process Tracing ................................................. 37

2.3 The Structured Focused Comparison and Data Collection .......................................... 40

3. Defining Federalism and its Application to EU Studies.................................... 43

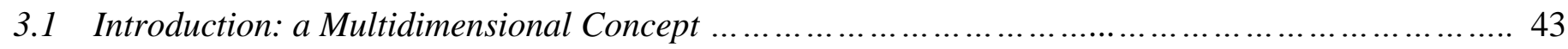

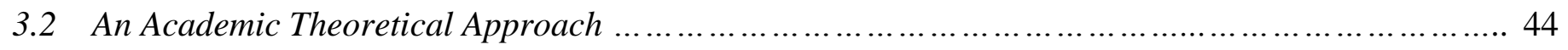

3.3 A Normative Political Concept ............................................................. 50

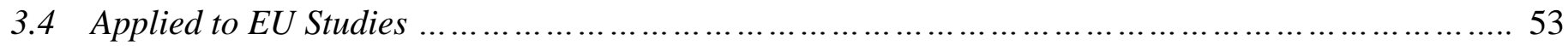

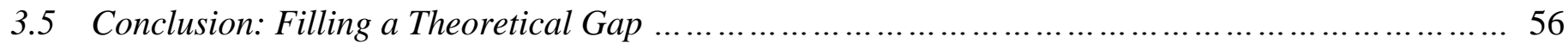

4. The Evolution of Economic and Monetary Integration in Four Stages .........................58

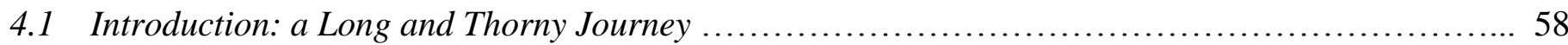

4.2 The Onset of Economic Integration and the First Experiments of Monetary Coordination (1950s-1968) 61

4.3 The Steps towards an Economic Union and a Single Currency (1969 to 1999) ..................... 85

4.4 Monetary Unification in Practice since 1999 .............................................. 113

4.5 Tackling the EMU Crisis since 2008: Euro Survival under Threat ............................ 125

4.6 Conclusion: More Crises? More Integration ....................................................................... 145 
5. Explaining Economic and Monetary Union: Various Approaches ............................ 147

5.1 Introduction: Supranational, State-Centric and Mixed Paradigms .............................. 147

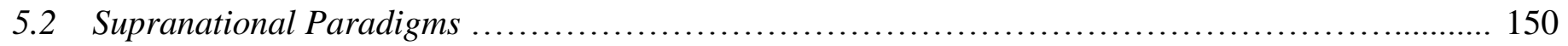

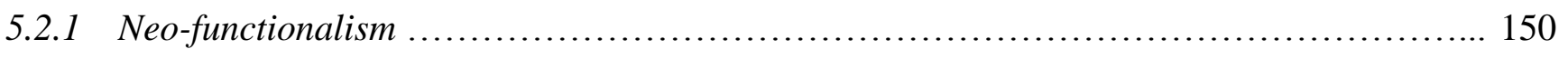

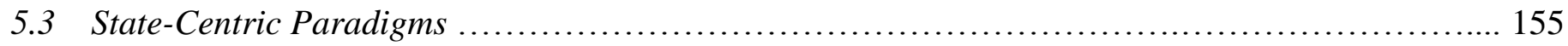

$5.3 .1 \quad$ Intergovernmentalism .......................................................... 155

5.3.2 Domestic Politics Theory ................................................. 162

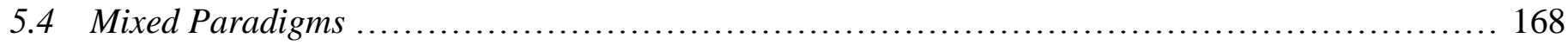

5.4 .1 Europeanization ............................................................. 168

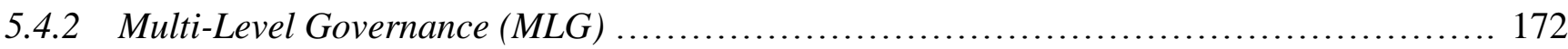

5.5 Conclusion: why Mixed Paradigms Work Better to Explain EMU ............................ 177

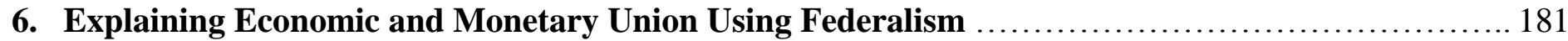

6.1 Conceptualizing Federalism and Testing it to EMU Policy, Policy and Politics ....................... 181

6.2 The Incremental Federalization of Economic and Monetary Affairs from the 1950s to 1968 ...... 188

6.3 Towards a Single Currency: Federalization of Monetary Issues (1969-1998) ................... 194

6.4 The Achievement of Monetary Union: Federalism in Action since 1999 ......................... 201

6.5 Tackling the EMU Crisis since 2008 Targeting Federalist Solutions ........................... 206

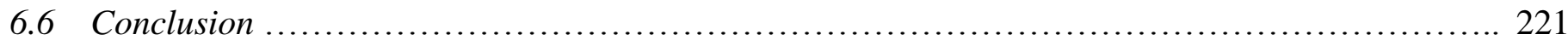

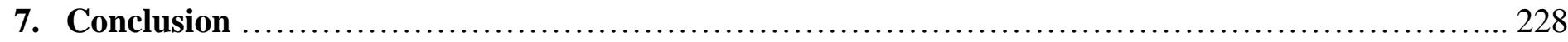

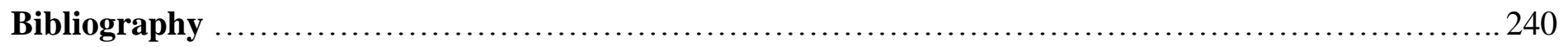

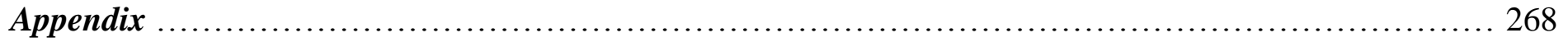




\section{List of Tables}

Table 1 - Real GDP growth rate (volume) - Percentage change on previous year.

Table 2 - Overview on EFSM AND EFSF loan disbursements

Table 3 - Classification of mainstream theories in three broad paradigms.

Table 4 - Explanatory leverage of three paradigms on EMU polity, policy and politics (at - supranational and domestic levels) in historical perspective.

Table 5 - Predictions of European integration theories on EMU polity, policy and politics.

Table 6 - Explaining EMU using a federalist structure (1950s-1968).

Table 7 - Explaining EMU using a federalist structure (1969-1998).

Table 8 - Explaining EMU using a federalist structure since 1999.

Table 9 - Explaining EMU using a federalist structure since 2009.

Table 10 - Explaining EMU using a federalist structure.

\section{List of Figures}

Figure 1 - The "Snake in the Tunnel".

Figure 2 - The "Cooperation Procedure". 


\section{List of Acronyms}

\begin{tabular}{|c|c|c|}
\hline $\mathbf{A E F}$ & - & Action Européenne Fédéraliste \\
\hline BoP & - & Balances of Payments Assistance \\
\hline CACs & - & Collective Action Clauses \\
\hline CAP & - & Common Agricultural Policy \\
\hline CFSP & - & Common Foreign and Security Policy \\
\hline CRIS & - & Financial, Economic and Social Crisis Committee \\
\hline CRU & - & Composite Reserve Unit \\
\hline EA17 & - & Euroarea with 17 members (since 2011) \\
\hline EBA & - & European Banking Authority \\
\hline EC & - & European Community \\
\hline ECB & - & European Central Bank \\
\hline ECBS & - & European Central Bank System \\
\hline EcoFin & - & Economic and Financial Council \\
\hline ECSC & - & European Coal and Steel Community \\
\hline ECU & - & European Currency Unit \\
\hline EDA & - & European Debt Agency \\
\hline EDC & - & European Defence Community \\
\hline EDP & - & Excessive Deficit Procedure \\
\hline EEC & - & European Economic Communities \\
\hline EFC & - & Economic and Financial Committee \\
\hline EFSF & - & European Financial Stability Facility \\
\hline EFSM & - & European Financial Stabilisation Mechanism \\
\hline EFTA & - & European Free Trade Association \\
\hline EIP & - & Excessive Imbalance Procedure \\
\hline EMA & - & European Monetary Agreement \\
\hline EMCF & - & European Monetary Co-operation Fund \\
\hline EMS & - & European Monetary System \\
\hline EMU & - & Economic and Monetary Union \\
\hline EP & - & European Parliament \\
\hline EPP & - & Euro Plus Pact \\
\hline EPU & - & European Payments Union \\
\hline ERM & - & Exchange Rate Mechanism \\
\hline ERM II & - & Exchange Rate Mechanism II \\
\hline ERP & - & European Recovery Program \\
\hline ESCB & - & European System of Central Banks \\
\hline ESM & - & European Stability Mechanism \\
\hline $\mathbf{E U}$ & - & European Union \\
\hline EU27 & - & European Union with 27 members (since 2007) \\
\hline EURATOM & - & European Atomic Energy Community \\
\hline
\end{tabular}




\begin{tabular}{|c|c|c|}
\hline G-10 & - & Group of Ten \\
\hline GDP & - & Gross Domestic Product \\
\hline IMF & - & International Monetary Fund \\
\hline JHA & - & Justice and Home affairs \\
\hline $\mathbf{L I}$ & - & Liberal Intergovernmentalism \\
\hline MFE & - & Mouvement Fédéraliste Européen \\
\hline MIP & - & Macroeconomic Imbalance Procedure \\
\hline MLG & - & Multi-Level Governance \\
\hline MTO & - & Medium Term Objective \\
\hline NMS & - & $\begin{array}{l}\text { New Member-States from Central Europe (Czech Republic, Hungary, Poland, } \\
\text { Slovakia, and Slovenia), Eastern Europe (Estonia, Latvia, Lithuania, and } \\
\text { Romania), and Southern Europe (Cyprus and Malta) }\end{array}$ \\
\hline OEEC & - & Organization for European Economic Cooperation \\
\hline OMS & - & Old Member States \\
\hline OMT & - & Outright Monetary Transactions \\
\hline QMV & - & Qualified Majority Voting \\
\hline RQMV & - & Reverse Qualified Majority Voting \\
\hline SCP & - & Stability and Convergence Program \\
\hline SEA & - & Single European Act \\
\hline SGP & - & Stability and Growth Pact \\
\hline SMP & - & Securities Market Program \\
\hline SRM & - & Single Resolution Mechanism \\
\hline SSM & - & Single Supervisory Mechanism \\
\hline TEC & - & Treaty establishing the European Community \\
\hline TEEC & - & Treaty establishing the European Economic Community \\
\hline TEU & - & Treaty establishing the European Union \\
\hline TFEU & - & Treaty on the Functioning of the European Union \\
\hline TSCG & - & Treaty on Stability, Coordination and Governance \\
\hline UEF & - & Union of European Federalists \\
\hline
\end{tabular}




\section{Introduction}

\subsection{Establishing the Importance of EMU}

The Economic and Monetary Union (EMU) represents one of the most integrated policies in the European Union (EU). EMU is composed of two terms: Economic and Monetary Union. In the EU case, the monetary union is (i) the adoption of a single currency (the euro), (ii) a single monetary authority - the European Central bank (ECB), and (iii) a single monetary policy across the euroarea (Verdun 2010: 325-326). As Ungerer (1997) and Verdun (2010) observed, EMU represents a substantial compromise between the economic and monetarist approaches, which were debated since the 1960s up to 1992 during the negotiations of the Treaty Establishing the European Union (TEU), also known as the Maastricht Treaty. Since an economic coordination was scheduled before introducing the single currency (and not the other way around, as theorized by monetarists), the economic and monetary unions were grouped under the same umbrella, ideally representing two sides of the same coin. Procedurally, while the single market has been reached mainly by the removal of barriers among EU members ("negative integration"), monetary integration could only take place with an incremental construction of institutions, policies, common rules, laws and standards to be shared among EU members ("positive integration").

Without doubts the circulation of euro coins and banknotes is the most tangible symbol of a unified and unifying Europe. The euro is the legal tender in 18 of the 28 members of the European Union ${ }^{1}$. The members outside the Eurozone (and Bosnia and

\footnotetext{
${ }^{1}$ Member states of the Eurozone as of 2014 are Austria, Belgium, Cyprus, Estonia, Finland, France, Germany, Greece, Ireland, Italy, Latvia, Luxembourg, Malta, the Netherlands, Portugal, Slovakia, Slovenia, and Spain.
} 
Herzegovina, currently a potential candidate to the EU membership), have pegged the value of their domestic currencies to the euro, and ultimately all of them are expected to adopt it, except for the legal opt out of Denmark and the United Kingdom, and a de facto tolerated opt-out of Sweden. Within the eurozone members, the euro is used by 331 million people (European Central Bank 2014a). With the inclusion of Montenegro and Kosovo that adopted the euro unilaterally, and four microstates allowed minting a very limited amount of euro (Andorra, Monaco, San Marino, and Vatican City), a total of about 334 million people use the euro in Europe. In 2013, the EU-28 GDP was the largest economy in the world, while the GDP of the Eurozone was second to the US (Eurostat 2014).

Worldwide, about 182 million people in Africa use currencies pegged to the euro (European Commission 2013a), since before the introduction of the euro they were pegged to the Deutsche Mark, the French franc, and the Portuguese escudo. The international use of euro has dramatically extended since its inception in 1999, challenging the US dollar as one of the world main currencies. As such, in 2013 the euro was the second largest reserve currency and the second most traded currency in the world after the US dollar (Boesler 2013). In 2013, with $€ 951$ billion in circulation, the euro has the highest value of circulating cash (bills and coins) in the world, followed by the US dollar (European Central Bank 2014b; Federal Reserve Bank 2014). This means that the euro has become widely used as an asset in foreign-exchanges reserves, even though the ECB did not deliberately promoted any international use of the euro and the US dollar is still the most popular reserve currency (Atkins 2006).

Looking at the second component of EMU, an economic union is defined as the coordination of macroeconomic policies among countries. More specifically, in the EU 
context the Economic Union corresponds to the four convergence criteria (also known as the "Maastricht criteria"), as delineated in 1992 concerning (i) inflation rates, (ii) government finance, (iii) long-term interest rates, and (iv) exchange rates. Members have to fulfill these in order to be admitted and to participate in the monetary union. Secondly, since 1997 the Stability and Growth Pact (SGP) agreement has been ensuring that members continue to observe the convergence criteria once they have adopted the euro. Taken together with the Free Trade Area, the Customs Union, and the Single Market, the economic union is the last of the four stages delineating the overall EU economic integration. To the single market, the economic union adds common competition, structural and regional policies, and macroeconomic policy coordination, including binding rules for budgetary policies and oversight on fiscal policies (Committee for the Study of Economic and Monetary Union 1989: 16).

In EMU, while the monetary union has been already fully accomplished, the economic union is still an ongoing project. Since 2009 the EU dealt with the rampant economic and financial turmoil that has hit the eurozone hard, precipitating rumors for a generalized default of several troubled Eurozone members such as Portugal, Greece, Italy, Ireland and Spain. As such, the existence of the euro was at stake too. However, the economic downturn represented an extraordinary opportunity to push for the achievement of a fully-fledged economic union. Hence, since 2010 European governments and the EU institutions have reached consensus on (i) the creation of rescue funds managed by the European Financial Stability Facility, the European Financial Stabilisation Mechanism, and the European Stability Mechanism, charged with disbursing loans for economies in difficulty, (ii) the "six-pack" reforms targeting a more stringent enhancement of 
macroeconomic, budgetary, and fiscal surveillance, (iii) the reinforcement of an EU fiscal governance framework comprised of the fiscal elements included in the "Six-pack", the Treaty on Stability, Coordination and Governance (TSCG) and the "two packs", (iv) the unprecedented purchase by the ECB of government bonds refinancing sovereign debts (through the Securities Market Program and the Outright Monetary Transactions program), (v) the Euro Plus Pact based on the Enhanced Co-operation procedure, according to which several members can decide on a voluntary basis to advance integration in a specific policy area, and (vi) a banking union introducing a single rulebook, common deposit protection and a single bank resolution mechanism covering all banks in the euro area.

From its inception in 1999 regulated by the Maastricht Treaty (1992), the EMU framework has been orchestrated through the "Community Method" that applies to policies where the EU has an exclusive competence, and balances powers of EU institutions with those of domestic governments and the European Council. This balance of power between EU and members' institutions in EMU is being regulated by the "Cooperation Method", which is characterized by the European Council setting policy targets and macro-directions, the Commission monopoly of the right of initiative, generalized use of qualified majority voting in the European Council, an active role for the European Parliament, and an interpretation of EU law by the Court of Justice (Cini and Pérez-Solórzano Borragán 2010). The original EMU polity, policy and politics remained relatively untouched by the treaties following Maastricht - the Treaty of Amsterdam (1999), the Treaty of Nice (2003), and the Treaty of Lisbon (2010) ${ }^{2}$.

\footnotetext{
2 After the Amsterdam Treaty (1999), EMU has been the only EU policy still regulated by the "Cooperation Method", while the Co-decision method became predominant in EU policy making.
} 
From a legal perspective, treaties regulating EMU have been rarely written from scratch, but have been almost always modified or amended following a cumulative logic. Before the Maastricht Treaty (1992) the basis of the economic union could be traced back to the Treaty establishing the European Economic Community (Treaty of Rome) of 1957, which represented the very beginning of the European integration enterprise. The legal roots of monetary union are more recent, lying in the experience acquired in the framework of the European Monetary System (EMS) established in 1979. Later, the Single European Act (SEA) in 1986 identified the creation of a common currency as a goal of the European Community.

As such, EMU as we know it now was not created in a vacuum, but was preceded by early pioneering and "utopian" discussions concerning the idea of a common currency took place in the 1950s and the 1960s, in a context dominated by domestic sovereignty. However, the European Payments Union (EPU) created in 1950 and a customs union achieved in 1968 showed some progress on the integration of economic and monetary affairs. A customs union consisted of the elimination of tariff barriers. From a monetary perspective, countries with a trade deficit were allowed to transfer their liabilities to the EPU, which worked as a credit line which had to be ultimately settled in US dollars and gold. Essentially, the EPU provided a sort of multilateral umbrella to prevent market distortions, promote intra-European trade, and cope with the structural inconvertibility of currencies with the only exception of the US dollar. The EPU worked until 1958, when it was replaced by the European Monetary Agreement (EMA), a multilateral settlement which restored the external convertibility of members' currencies in the framework of the Bretton Woods system. 
Such progress became more tangible in the 1970s from any standpoint. Material steps were taken towards monetary unification after the full achievement of a customs union. Monetary unification was a theme that gained momentum after the collapse of the Bretton Woods Agreements in 1971. As such, the Werner Report unsuccessfully targeted a monetary union in 1980 but represented a fundamental source of inspiration for the later evolution of EMU. The "Snake in the Tunnel" was a technical solution adopted since 1972 by EEC members aimed at keeping the flotation of European currencies against each other under control. And finally the European Monetary System (EMS) in 1979 represented the prerequisite to move forward and seek an economic and monetary union. The EMS and its centerpiece, the Exchange Rate Mechanism (ERM), were an arrangement set to stabilize European currencies and European economies after the collapse of Bretton Woods.

In 1986 the Single European Act (SEA), intended as a legal amendment of the Treaty of Rome, codified a number of major economic preconditions for fair competition and long-term stability within the internal market. The most important one was the complete liberalization of people, goods, services and capital movements in the EC, the so called "single market" that would be achieved in 1992. On monetary issues, it incorporated the development of the European Currency Unit and mentioned that monetary union should be a reachable goal of the EC, although SEA did not plan how and when this could be achieved (Hix 2005). This integrationist trajectory finally culminated with the Maastricht Treaty in 1992, laying down the three steps to achieve EMU in 1999. The introduction of the euro coins and bills in the financial markets since 1999 and the real circulation in the Euroarea since 2002 represented the real game changer, featuring a complete shift of monetary sovereignty toward the European Central Bank that complemented the already existing single market. 


\subsection{Synopsis of the Literature on EMU Integration}

This dissertation draws on the assumptions found in the current mainstream literature on European integration that is the process of economic, legal, political, and socio-cultural integration of the European countries within the European Coal and Steel Community (ECSC) since 1952, the European Economic Community since 1957, and the European Union since 1992. From a theoretical perspective, European integration (not only limited to economic and monetary affairs) has been explained by various mainstream theories. At the beginning, the main source inspiring my research design is a book edited by Amy Verdun in 2002 titled The Euro: European Integration Theory and Economic and Monetary Union. The book analyzed EMU from different theoretical perspectives, such as neo-functionalism and intergovernmentalism (Verdun 2002; Wolf 2002), Multi-Level Governance (Loedel 2002), Europeanization (Dyson 2002), and domestic politics (van Esch 2002).

In 2002, Verdun concluded that "[intergovernmental and neo-functional] theories need to be merged in order for us to obtain a better picture of the actors involved in the European integration process" (Verdun 2002: 15). Based on the case of the EMU, Verdun observed that by taking together the two theories - supranational (neofunctionalist) and state centric (intergovernmental) -, the whole picture of the EMU can be portrayed. Also, departing from a game theory standpoint, Wolf (2002) concludes that the amalgamation of the two approaches will result in a better understanding of the monetary union. Other authors like Buonanno and Nugent (2013) believe that neither intergovernmentalism nor neo-functionalism, used in combination or complementarily, can provide a satisfactory explanation of EMU. They consider 
federalism as a distinct theory equipped with its own concepts and, as such, able to provide a better interpretation when it comes to the process of integration, not necessarily limited to EMU.

More research has refined the correlation of European integration theories and EMU. Other important sources complementing the study of EMU from an integration perspective are Moravcsik (1998), who wrote a chapter delineating EMU as a case of liberal intergovernmentalism, and Pinder (1998), who provided an early analysis of EMU using federalism. More recently, Dandashly and Verdun (2009a, 2009b) worked on the domestic politics behind the decision to adopt or reject the euro from new member states from Central and Eastern Europe. This limited but very important aspect of EMU calls for an apparent resurgence of state-centric factors affecting EMU.

The inception of the financial crisis that has affected the Eurozone was recently analyzed through the lenses of integration theory, showing that the debate is still vibrant and controversial. As a result, a new wave of integration studies has updated the existing literature. On the one hand, several scholars such as Puetter (2009), Moravcsik (2012, 2013), and Glencross (2013) revived intergovernmentalism reaffirming the centrality of the European Council as a prominent player, acting as a de facto "presidential" actor (Kunstein and Wessels 2013). Taking a more critical stance, Fabbrini (2013a, 2013b) observed that "the extremely complex system of economic governance set up for answering the euro crisis has been defined and implemented on the basis of the intergovernmental constitution of the EU [but] the intergovernmental approach faced a structural difficulty in solving basic dilemmas of collective action" Fabbrini (2013a:1008). Similarly, Kunstein and Wessels (2013) noted that the attempt to centralize EMU policy has been complemented by the uneven application of EU rules in some members, causing differentiated forms of integration. Concerning other state centric approaches, analyses where 
produced looking at the domestic responses to the financial crisis in the cases of Southern Europe (Pagoulatos and Quaglia 2013) and the Baltic states (Vilpišauskas and Kuokštis 2013). On the other hand, a parallel process of empowerment EU institutions in the decisional process with the Treaty of Lisbon (assessing a more decisive role to the European Parliament) and centralization of EMU at the expenses of domestic sovereignties has produced papers reviving the neo-functionalist approach (Niemann and Ioannou 2013; Spendzharova, 2013).

Other studies look at EMU from a two-level game perspective. Jabko (2013) argues that the divided sovereignty of the EMU as a byproduct of the conflict in the Maastricht Treaty between domestic and supranational sovereignty. Another recent analysis mixing intergovernmentalism and supranationalism was provided by Radaelli, Dunlop and Kamkhaji (2013) when arguing that the solutions adopted to tackle the crisis since 2010 used both approaches. Finally, Snaith (2011) identified several relevant indicators of multi-level statehood showing that that EMU architecture can be classified as multi-level governance.

From the very beginning of my research on EMU, my main critique has been that most integration theories already adopted to explain EMU are one-dimensional in explaining just a few, limited aspects of EMU. In fact, despite the richness of every theoretical insight, no one has been able to offer a comprehensive account of EMU. In this way, from a politico/institutional perspective I assume that intergovernmentalism, Europeanization, domestic factors, and MultiLevel Governance theories, taken alone, are insufficient to explain past dynamics and future evolution of EMU. The need to merge the neofunctionalist and intergovernmental approaches, as invoked by Verdun, and the threefold concept of Europeanization (bottom-up, top-down and horizontal), are examples of multidimensional explanations highlighting that each theory has explanatory flaws. Furthermore, several theories partially overlap, and all have some weaknesses 
which will be addressed in my research. The limits of these theories will be carefully delineated in the literature review chapter.

\subsection{Federalism and $E U$ Studies}

Federalism is a multifaceted term. The first broad understanding of federalism is a value-neutral academic theory and a practice denoting a division of power between two relatively independent levels of political authority in a country, aimed to produce policy. On the one hand, the meaning of "relatively independent" is that each level has "some activities on which it makes final decisions" (Riker 1975:101). On the other hand, on several issues the two levels come to a compromise. A central government is responsible for the entire country, and sub-central governments are held accountable for the governance of specific jurisdictions in the country, with each performing a role in the policy process (Auer 2005; Obinger, Leibfried and Castles 2005; Siaroff 2005). As a practice, federalism was firstly seen in the United States, but has been also adopted in other 26 countries including (but not limited to) Australia, Brazil, Canada, Germany, Mexico, and Switzerland. Concerning the European Union, there is debate whether it is unique, a loose confederation, or moving towards a fullyfledged federation.

Usually a federation is established through a constitution and is based upon the judiciary power to resolve jurisdictional disputes (Watts 1998). Constitutional federalism denotes a constitution defining the constituent units of the federation, detailing the distribution of power between the latter and the central unit, and providing for a conflict resolution scheme between the two levels (Auer 2005). In contrast, less reliance on litigation 
and judicial interpretation denotes Discretionary Federalism (Kelemen 2004) since written laws work as a general framework permitting a certain degree of flexibility in application by the lower-level jurisdiction, usually that of constituent units.

Analytically, there are various subsets of federalism. Vertical federalism denotes the allocation of power between the central government and the constituent units. Whereas this allocation of power can occur in various ways, generally in a federal system there is a balance of competencies between the two levels (Buonanno and Nugent 2013). Horizontal federalism (Zimmerman 2011) focuses on the relationships between constituent units with minimal involvement at the central level. In a federation, it comprises various mechanisms to solve interstate disputes and develop interstate cooperation. In a full-fledged federation, there is a balance of power between the centralized government and the constituent units, thus equalizing horizontal and vertical federalism. In a confederation, horizontal federalism predominates over vertical federalism, since the institutions at the central level heavily depend on the decisions taken by the constituents units (Watts 1998).

There are various subset of federalism. Dual federalism or "Layer cake federalism" was introduced by Grodzins (1966) to define a system in which the powers of the government hierarchy are clearly spelled out and kept separated. Cooperative federalism or "marble cake federalism" defined by Grodzins and Elazar (1984) occurs when cooperative partnerships between federal and state governments are put into place. Symmetric Federalism takes place where there is no distinction between constituent states. Asymmetrical federalism occurs when several constituent units possess different powers, like more autonomy or specific rights than other constituent units, although they have an identical constitutional status (Watts 1999; Brown 2005). An extreme case of an asymmetric federation has been 
defined as Federacy by Stepan (1999), which represents a midway between unitary and federal states.

Federalism is a concept that applied to various policies. As suggested by Musgrave (1959) and Oates (1972), Fiscal Federalism lays out a framework for the assignment of proper fiscal instruments at the various levels of government in line with the functions they are constitutionally authorized to carry out. From an economic perspective, Viner (1950), Tinbergen (1954), Meade (1955), and Balassa (1961) identified a stage-based integration model whose path, logic and goal resembles a form of Economic Federalism, including the creation of a free trade area, a customs union, common market, economic union, monetary and fiscal union, and political union.

Secondly, federalism as a political concept has normative and ideological implications, since political advocates of federalism (or "supranationalists" in Europe) generally want a balance of power between two layers of government. In the case of the US, during the critical confederal years 1781-1789, the powers of the central government were very limited if compared to the excessive governmental authority of the individual states. However, the powers of the individual states were limited if compared to the major European countries that colonized North America. In order to provide the American states a single voice, a bottom-up shift of power took place to empower the confederal government in foreign relations capacity, diplomacy and trade vis-à-vis the Britain, France and Spain. Furthermore, the consolidation of powers of federal government including the printing of money and levying of taxes was a measure to tackle massive public debts and a fiscal crisis incurred during the Revolutionary War in the 1780s (Morison and Commager 1962: 269 272). Similarly, federalists in EU politics claim for more centralization of powers at the EU 
level, given the former history of absolute sovereignty by individual European countries. The most prominent European federalist movements after World War II admired US institutions and attempted to emulate dimensions of it (Spinelli and Rossi 1944; Congress of Europe 1948). They were succeeded by later supporters including an epistemic community of technocrats and civil servants that made the evolution towards the European Union possible.

It is nearly impossible to convey the dynamic of any federal system without comparing it to the United States, the first and foremost historical example of federalism. Looking more specifically at Europe, this comparison makes particular sense for at least two reasons: the first one is that the US has always represented a federalist model for European integration. Furthermore, from an international relations perspective, the US got involved in European affairs after WWII pushing for a European integration project to ensure reconstruction, peace and prosperity in countries devastated by years of war. Hence, the US exercised an idealistic but also pragmatic influence for Europeans.

Especially since the 1990s, the division of competencies between the EU and its member states in a multilevel political system has represented an ideal case for scholars to apply the concepts of federalism (cf. King 1982; Rhodes and Mazey 1995; Watts 1998, McKay 1999; Weiler 1999; Fabbrini 2005; Burgess 2006: 226-245; Menon and Schain 2006; Dosenrode 2007; Leonardi and Nanetti 2007: 288-304). These authors share the idea that the organization of the EU is based upon the existence of a voluntary union with a central authority created by its member states. Under this theory, institutions promoting the EU interests and prerogatives such as the European Commission, the Parliament and the Courts constitute this centralized sphere, whose predominance is counterbalanced by institutions defending member-states' interests, through the intergovernmental method. Taken together, 
the decision-making shared between these two types of institutions denotes what an empirical federation is.

The EU can be also seen as an archetype of confederation. According to Forsyth (1981) and Burgess (2000), the main confederal institutions of the EU are the intergovernmental conferences of the European Council, composed of the governments of the various member states. In addition, from a policy perspective, depicting the EU as a confederation is still persuasive for policies still mostly managed at the domestic level, such as foreign policy and taxation. The political reverberation of this situation is that members still want to retain an almost exclusive sovereignty on several sensitive policies, where the EU has little or no legislative power and no power of judicial review.

Finally, the EU can be seen as an example of on-going federalizing system. There are few doubts that the EC started as a loose international organization in the 1950s. However, as noted by Fabbrini (2002: 6) "the EU has since then gradually reduced its original intergovernmental configuration to acquire more the features of a supranational organization, without acquiring nevertheless the features of a full blown federation". On the one side, confederalism was necessary at an early stage to make the integration possible without threatening the sovereignty of members. On the other side, federalism allowed a centralized execution of several policies fully integrated at the supranational level, like the monetary union. Others suggest that the EU is a case of "emerging federalism" (Macmahon 1962), federalization (Trechsel 2005), would-be federation (Bendnar, Ferejonh and Garrett 1997) and "federal integration model" as suggested by Buonanno and Nugent (2013). 


\subsection{Research Questions, Hypotheses and Methods}

Given its inherent nature, EMU is a topic that can be approached from extremely different analytical angles, in terms of historic evolution, monetary policy, legal standpoint, neo-liberal project, macroeconomic modelling, institutional building, and political negotiations, among others. These fields are inherently interconnected among themselves but at the same time maintain a peculiar insight at looking at the EMU with distinctive theories and methods. All provide a better understanding of EMU, but it is imperative to clarify the direction that I will adopt in the writing of this dissertation.

I look at EMU as a polity - or a multilevel structure or framework - in which EU and domestic initiatives - broadly defined as politics - determine the EMU policy. I define polity as the legal venue where powers, authority and sovereignty are allocated. Politics are the arenas where the actors (mainly the EEC/EU and its members) bargain to gain authority or power over EMU or negotiate to find acceptable compromises that satisfy all parts. Policy is how the monetary and economic game is actually delivered. My definition was inspired by

John W. Kingdon's model on agenda setting. Kingdon (1984) provided a framework to analyse the process of public policy making. This model is based on the inclusion of the participants inside and outside governments, i.e. polity. The decision making process starts with the emergence of a problem, the identification of several policy alternatives that could solve the problem, and the political bargain necessary to build consensus on a solution. In addition, my conceptualization of federalist theory including polity, policy and politics was inspired by Simona Piattoni (2010) who tested these three mainstream concepts on MultiLevel Governance theory. 
A number of studies examine the negotiations that occurred during the institutional framing of the monetary integration, therefore paying particular attention to EMU polity and policy as a "politically driven project" (Hosli 2005:15). Dyson emphasizes "the causes and political motives of actors and deeper political developments" leading to the creation of EMU (Dyson, 2002b: 22). This assumption is reiterated by Tsoukalis (1977), Jones (2002), and Hix (2005). These scholars legitimize the purpose to study monetary union from a policy, political and institutional perspective, following the assumption that it is no less important than other approaches. From the very beginning, hence, it is legitimate to look at EMU as an example of policy evolved through political entrepreneurship and polity reconfiguration.

This dissertation lies at the crossroads of three different subfields of political science: comparative politics, international relations, and political theory. These three subfields are taken into account in various degrees, since all of them provide an hypothesis that I will test in the dissertation. The first and most important aim of this dissertation is to analyze "how" EMU has been politically developed, how policies have been implemented, and how the polity has changed over the decades. In this regard, I am looking at the various mainstream theories attempting to explain EMU: neo-functionalism, Europeanization, Multi-Level Governance, intergovernmentalism, and domestic politics. The comparison of these approaches clearly places this dissertation in the comparative politics field. Further, since what is being compared is meta-theoretical, a considerable degree of political theory is manifest as well. Finally, these integration theories are based on the two-level game developed by international relations. 
Regarding the "how" the economic and monetary integration has been crafted over the years, in its polity, policy and political configurations, this dissertation contribution lies in the adoption of a under-utilized theory - federalism - to explain the overall evolution of the Economic and Monetary Union from its origins up to the recent economic and financial crisis. From this standpoint, this dissertation provides an updating to the existing federalist studies already available on EMU and a reconceptualization of federalism applied to EMU. As such, my first hypothesis is that federalism is the mechanism through which EMU has been arranged and operates. The alternative hypothesis is that EMU is better explained by another mainstream theory (neo-functionalism, Europeanization, Multi-Level Governance, intergovernmentalism, or domestic politics) or a combination of them. Concerning this hypothesis, my dissertation represents a replica of Tsoukalis (1977), whose research design before the building of the European Monetary System (EMS) provided a detailed historical overview of economic and monetary integration from its origins to the 1970s, with the aim of testing three theories: federalism, neo-functionalism and intergovernmentalism.

Tsoukalis (1977: 170) concluded that "the history of EMS has shown that the Community has gradually evolved towards a more intergovernmental type of organization. Therefore it would be erroneous to base a strategy for economic and political integration mainly on the supranational institutions". At that time, Tsoukalis had to exclude both neofunctionalism (because of some empirical evidence playing against it), and federalism (since EMU was not in practice yet), but his conclusion compromising intergovernmental and supranational pressures seems in line with Verdun (2002) and Wolf (2002) emphasis on the opportunity to adopt mixed approaches. 
The second hypothesis is still deducted by the mainstream integration theories that inevitably rely upon the "two-level game" assumptions found in international relations (Waltz 1959; Gourevitch 1978; Putnam 1988). In this regard, I will consider in great detail the multi-level structure where EMU integration dynamics has taken place, emphasizing the importance of both domestic and supranational factors. As such, I will categorize the mainstream theories identified above within three families: (i) state-centric paradigms (intergovernmentalism and domestic politics) emphasize the predominant role of domestic governments over EC/EU institutions; (ii) supranational paradigms (neo-functionalism) envision a decisive role of the EC/EU over domestic governments, and (iii) mixed paradigms (federalism, Europeanization, and Multi-Level Governance) combine state-centric and supranational approaches, assuming that there is a balance of power between the EU and its member states. My hypothesis is that, given the current status of EMU integration, mixed paradigms have a higher explanatory leverage than the state-centric and supranational paradigms.

In extreme synthesis, I challenge the leverage of intergovernmentalism to explain EMU, especially since its execution is completely managed by EU institutions. As well, domestic politics are only able to explain certain limited aspects of EMU. On the other hand, a pure supranational approach such as neo-functionalism is incorrectly dismissive of the constituent units of the EU, i.e. the member states. I believe that mixed approaches provide a better understanding of EMU. As such, I do not challenge the leverage of Europeanization and Multi-Level Governance, but I believe that federalism is a better fit since it is a theory developed before EU and EMU integration and not after it, such as Europeanization and 
Multi-Level Governance, developed in the 1990s to capture the "inevitable" progress in the European integration and the "point of no return" of EMU.

International relations also shed light on the causes of the existence of EMU ("why") an aspect that is not secondary to the abovementioned "how" EMU has been politically developed. This has to do with the third hypothesis of my dissertation. Concerning the motives triggering the successful push for further integration (the "why") I adopt and extend the finding of Künhardt (2013) when arguing that crises affecting the survivability of economic integration should be seen as engines of progress throughout the history of European integration. For Künhhardt, crises have frequently destabilized the existing status quo instigating the need for a reaction, which often was finalized to strengthen European integration. The alternative hypothesis is that any major crisis erupting in the international system undermines European integration, causing a return to state-centric sovereignty or intergovernmentalism. With specific reference to EMU, the most extreme consequence would be the collapse of the monetary union together with serious risks for the survivability of the EU.

Building on this dialectic logic of challenge and response, von Hagen (2013) identifies two waves of economic and monetary integration. The first one is the creation of the European Economic Community in 1957 and the Customs Union fully achieved at the end of the 1960s as a response to World War II and the subsequent Cold War. The second trend occurred in 1979 with the launch of the European Monetary System as an arrangement to stabilize European currencies after the collapse of Bretton Woods in 1971, which brought about a decade of widespread monetary instability in Europe. I assume that other three waves can be identified thereafter. The third one consists of the attainment of the Single Market in 
1992 as a direct response to the rising competitiveness of the Japanese economy and the Asian Tigers (Hong Kong, Singapore, South Korea, and Taiwan) in the 1980s. The fourth one, as already noted by von Hagen (2013) and Kühnhardt (2009), is represented by the achievement of a monetary union as a direct consequence of the end of the Cold War in 1991 that caused fears in Europe towards a too powerful Germany after its unification. Finally, I believe that the fifth wave is taking place since 2009. The current attempt to seek a fiscal and banking union, together with the enhancement of macroeconomic and budgetary surveillance and the rescue funds mutualizing the risks of a sovereign default, represents an integrationist reaction to tackle the severe economic downturn and financial turmoil that recently hit hard the Eurozone.

Concerning the methodology, in order to demonstrate the validity of my hypothesis, I utilize two interconnected qualitative methods: process tracing and structured focused comparison. Process-tracing is a qualitative method, useful for comparative research designs. According to Aminzade (1993: 108), process tracing provides "theoretically explicit narratives that carefully trace and compare the sequences of events constituting the process under investigation $[\ldots]$. By comparing sequences, we can determine whether there are typical sequences across cases". For George and McKeown (1985), process tracing works by identifying all of the observable implications of a theory. Once extracted, these implications are tested empirically, often through the method of interviews, primary and secondary searches, and other forms of data analysis. According to George and McKeown (1985: 35), this method allows "investigat[ing] and explain[ing] the decision process by which various initial conditions are translated into outcomes". For both process tracing method and federalist theory, particularly relevant are the issues of timing and incrementalism. 
The structured focused comparison developed by George and Smoke (1974), George (1979) and George and Bennett (2005), complements the abovementioned process tracing. In 1979 George invented the term "structured, focused comparison" to refer to a qualitative method to be adopted in small-N research. The method is "focused because it deals selectively with only certain aspects of the historical case" (George, 1979, 61). In my case, the case narratives and comparisons of my research design are centered on the conceptualization of policy, polity and politics, across four different integration waves. In my research design, the general question is whether or not federalism can provide a satisfactory explanation of the overall history of European monetary integration. In more detail, I use EMU as the case study to test various integration theories, including federalism.

\subsection{Significance and Limitations of the Study}

With reference to European monetary unification, two kinds of brief sui generis sources adopting a federalist focus are available. The first one widely reported by news and incidentally by scholars, refers to EMU as a kind of "common sense" federalism, since the circulation of euro across Eurozone members can be considered one of the most visible examples of a "federalizing EU". However, surprisingly enough the possibility to analyze the EMU as a case of institutional federalism seems not to be investigated in-depth by mainstream literature dealing extensively with the topic of EMU and European integration.

This first contribution of this dissertation lies in the adoption of a under-utilized theory - federalism - to explain the overall evolution of the Economic and Monetary Union (EMU) from its origins up to the recent economic and financial crisis. This research, 
therefore, is aimed to fill a gap in the literature currently approaching monetary union. The departure point of this enterprise, hence, is not a personal bias for the federalist theory, but the unprejudiced assumption that a federalist explanation of EMU is possible and desirable to advance knowledge on European integration theories.

My intention is to show that federalism has the power to explain the overall complexity of the EMU project in its implementation and execution from its beginning to current troubles. I believe, in fact, that applying federalism to EMU encompasses other contending approaches in one theoretical focus, providing a parsimonious, structural, and multilayered explanation able to elucidate the overall EMU evolution. This conclusion does not necessarily envision the EU as a full-fledged federation in any given policy area (like the US) now or in the near future, thus the results of this dissertation cannot be generalized to other policy areas without a further investigation. Therefore, I do not attempt to generalize findings outside this specific policy, since the EU still has limited executive powers in many policy areas that make it appear to be a loose international organization. Nevertheless, the execution of economic and monetary union is an exclusive competence of the EU that can be explained using federal theory.

As far as the historic evolution of EMU is concerned, even if the main focus of this dissertation is not to compare the evolution of monetary and economic policies in the EC/EU and elsewhere, it is nearly impossible to convey the federal dynamic of EMU without comparing it to historical examples of federalism, especially the United States. This comparison makes particular sense for at least two reasons: the first one is that the US has represented a federalist model for European integration not only in the past but also now. In fact, the current federalist solutions proposed to tackle the financial crisis affecting several 
European Countries and the Eurozone since 2010 resemble the consolidation of powers of federal government that occurred in the 1780 s to face a fiscal crisis associated with servicing debt incurred during the Revolutionary War. Furthermore, from an international relations perspective, the US got involved in European affairs after WWII pushing for a European integration project to ensure reconstruction, peace and prosperity in countries devastated by years of war. Hence, the US hence exercised an idealistic but also pragmatic influence, including the possibility of achieving an economic and monetary unification in Europe.

The risk of using such a broad approach in attempting to explain the overall EMU development adopting a single theory - federalism -, has some implicit risks and caveats. I am aware that it is almost impossible in the writing of a dissertation to take into account all the political, policy and polity ramifications of EMU. However, the empirical chapter will offer a broad overview on what I see as the major federalist elements of EMU. Secondly, the idea that any institutional and political evolution that has taken place in EMU can be explained by a theory is an ambitious goal that could generate a vague overstretching concept and a sort of "theoretical reductionism" in order to force the theory to fit the empirical facts, or "empirical reductionism" when facts are forced to fit the theory. Another problem is the possible existence of "micro-events" that could temporarily falsify the macro-theory and generate problems of internal validity, defined as the approximate truth about inferences regarding cause-effect or causal relationships (Trochim 2005). One example is the failure of the Werner Plan in 1971 (event one) which elicited a temporary return to domestic politics in the first half of the 1970s (event two). However, that failure ultimately triggered further integration in the second half of the 1970s with the creation of the European Monetary System (event three). If the causal analysis is delimited to events one and two, it might 
contradict federalism, but the inclusion of event three finally rescues it. The label "microevents" should not be confused with "minor events". Actually, often they represented major events, suck us the collapse of the Werner Plan. Thus, "micro" refers to the temporal length of the event (usually months or years), which is "micro" if compared to the overall duration of EMU integration process, lasting for seven decades.

From a normative perspective, another problem is that federalism has been criticized as being a deterministic approach since it considers human enterprises as finalized towards a permanent goal (in this case the irreversibility of the monetary union). According to these assessments, federalism would be less than scientific, but merely descriptive, at its best. In this regard, to support my hypothesis I assume that federalism has the merit to highlight the dynamic and constitutive epistemological development of EMU. This does not mean that the overall EU might be necessarily federal, but I believe that the overall evolution of the European monetary integration can be seen as an incremental process. Whether irreversible or not, is too early to call, but, for instance, I argue that the current attempts to deal with the economic and financial crisis suggest federalist solutions, as I will clarify in chapter 6. It indicates that since EMU rules have been constantly revised to optimize its functioning, the dissolution of the euro itself seems not to be a feasible option, even in bad times. However, at least theoretically, the European Council in charge of providing macro directions and targets to the Commission could decide to dismiss EMU itself. 


\subsection{Chapters Outline}

The dissertation is outlined as follows. The second chapter outlines a succinct clarification about the deductive nature of the research design (section 2.1) and the methodology that I will adopt in the rest of the dissertation. Section 2.2 deals with the method of process tracing that will allow me to elucidate the narration of the overall history of economic and monetary integration, while section 2.3 illustrates the structured focused comparison that is the basis for the comparison of the various mainstream theories already available in explaining EMU. The final section mentions how I collected data.

In the third chapter I provide a general discussion of the various historical understandings of federalism (section 3.1) in its various configurations: as a value-neutral academic theory (section 3.2); a normative and ideological political concept adopted in European politics (section 3.3); and an empirical practice originally realized in the United States that has been used by scholars of European studies as a model applicable to analyze the integration path occurred in the European Economic Community and in the European Union (section 3.4). Finally, this chapter will outline why it is important to apply federalism to EMU. Despite the existence of earlier analyses interpreting EMU as a case of federalism, recent investigations did not consider applying federalism to the latest events occurred in EMU, therefore opening a theoretical gap.

In the fourth chapter, I delineate an historical overview of the process pertaining to economic and monetary issues, outlining the role of EU institutions and EU member states in setting monetary policy, and highlighting the pivotal acts that contributed to the framing of monetary union. The aim of this historic chapter is to highlight the interplay between domestic and supranational factors in shaping EMU from the very beginning, a pivotal aspect that I will 
take into account in my empirical chapter dedicated to applying federalism to EMU. The chapter is divided into four sections, each reflecting a different phase of EMU history: the onset of economic integration and the first experiments of monetary coordination (1950s-1968); the steps toward a real common currency from 1979 to 1998; monetary unification in practice since 1999; and Euro survival under threat amidst economic and financial turmoil since 2010. The conclusion of this empirical chapter is that at any given time crises potentially causing the failure of the EEC/EU worked instead as an engine to trigger more integration.

The fifth chapter consists of the literature review that takes into account mainstream theories found in the current literature on European Union integration. In explaining EMU, such theories sometimes conflict with each other and sometimes partially overlap, but all have some weaknesses that will be examined in this chapter. More specifically, EMU has already been analyzed by neo-functionalism, intergovernmentalism, Multi-Level Governance, Europeanization, and theories focused on Domestic Politics. My purpose is to test the explanatory powers of these theories against one another using monetary union as a prominent policy case. Some scholars adopted a supranational paradigm envisioning a decisive role of the ECC/EU towards promoting further investigation. In this regard, I assume that the only supranational approach is neo-functionalism. Two other theories (intergovernmentalism and domestic politics) can be classified as state-centric since they emphasized the predominant role of domestic factors, broadly defined. Finally, I claim that federalism, Europeanization, and Multi-Level Governance belong to the mixed paradigm, which by definition merges both approaches. In my opinion, in the case of EMU mixed approaches provide a higher explanatory leverage than others. 
In the sixth chapter I delineate my specific analysis of how federalism applies to EMU. I make a prima facie use of the typical concepts provided by federalism - such as federalization, and vertical and horizontal federalism -, and then I apply them to three aspects of EMU (polity, policy and politics) across four different historical stages. I explain the rise of integration in economic and monetary affairs from the 1950s to 1999 in terms of federalization. Since 1999, a federalist system can be identified by the execution of EMU at the EU level (explained in terms of vertical federalism) and by the ongoing power of the Council (explained in terms of horizontal federalism) to set changes in EMU. Finally, the current "neo-federalizing" negotiations (horizontal federalism) targeting centralized solutions (vertical federalism) to face the ongoing financial crisis affecting the Eurozone can be explained using a federalist theory too. 


\section{Methodological Note: Process Tracing and Structured Focused Comparison}

Before the presentation of federalism (chapter 3), the overall evolution of economic and monetary integration (chapter 4), the main traditional theories on European integration (chapter 5), and my application of federalism to EMU (chapter 6), I believe it is necessary to provide a succinct clarification about the deductive nature of the research design (in the following section) and the methodology that I will adopt in the rest of the dissertation. Section 2.2 deals with the method of process tracing that will allow me to elucidate the narration of the overall history of economic and monetary integration, while section 2.3 illustrates the structured focused comparison that is the basis for the comparison of the various mainstream theories already available in explaining EMU. Section 2.3 also mentions how I collected data.

\subsection{The Deductive Nature of the Research Design}

The most important question represents the real starting point of this dissertation -- which theory can provide a better explanation of the overall history of European monetary integration? The research question highlights that this dissertation adopts a deductive research strategy, based on theory, through which the empirical case of EMU will be analyzed. Departing from the traditional theories formulated on European integration, I use EMU as a case to test them, introducing federalism too. In framing my research design, I was mainly inspired by two sources.

The first one is The Politics and Economics of European Monetary Integration by Loukas Tsoukalis (1977). Before the building of the European Monetary System (EMS), 
Tsoukalis provided a detailed historical overview of economic and monetary integration from its origins to the early 1970s, with the aim of testing three theories: federalism, neofunctionalism and intergovernmental cooperation in European affairs. Given the abrupt failure of the Werner Plan, Tsoulakis in 1977 concluded that the EEC integration project on economic and monetary issues witnessed a resurgence of intergovernmentalism. Based on what happened thereafter, this view needs to be questioned. In the long run federalism may be "overtaking" other approaches.

Another source inspiring my research design is a book edited by Amy Verdun in 2002 titled The Euro: European Integration Theory and Economic and Monetary Union. Every chapter of the book was aimed to analyze EMU from different theoretical perspectives, such as neo-functionalism and intergovernmentalism (Verdun, 2002; Wolf 2002), Multi-Level Governance (Loedel 2002), Europeanization (Dyson 2002), and domestic politics (van Esch 2002). The general conclusion of the book is that "theories need to be merged in order for us to obtain a better picture of the actors involved in the European integration process" (Verdun 2002: 15). Furthermore, based on the case of the EMU Verdun observed that by taking together the two theories - supranational (neo-functionalist) and state centric (intergovernmental) -, the whole picture of the EMU can be portrayed. Similarly, departing from a game theory standpoint, Wolf (2002) concluded that the amalgamation of the two approaches will result in a better understanding of the monetary union. I believe that federalism provides an explanatory answer to the need of theoretical eclecticism identified by Verdun (2002) and Wolf (2002). From this point of view, in my opinion federalism "overlaps" supranational and intergovernmental theories, explaining the EMU. 


\subsection{The Evolution of EMU through Process Tracing}

In order to demonstrate the appropriateness of my hypothesis, I utilize two interrelated qualitative methods: process tracing and structured focused comparison. Process tracing is the basis of the narration of the empirical process pertaining to the EMU that I will develop in chapter 4. Process-tracing is a qualitative method, useful for comparative research designs, which has been deemed appropriate to develop case studies in political science (Ruback 2010). I believe there are affinities between the method of process tracing and federalist theory. For both, in fact, particularly relevant are the issues of timing, sequencing, incrementalism, fluctuation between inertia and impulse toward integration, experimentation, interaction effects, and the relevance of key events.

This method has been recently revitalized by Collier (2010, 2011) and Falleti (2006). According to Aminzade (1993: 108), process tracing provides "theoretically explicit narratives that carefully trace and compare the sequences of events constituting the process under investigation $[\ldots]$ by comparing sequences, we can determine whether there are typical sequences across cases". For George and McKeown (1985), process tracing works by identifying all of the observable implications of a theory. Once extracted, these implications are tested empirically, often through the method of interviews, primary and secondary searches, and other forms of data analysis. According to George and McKeown (1985: 35), this method allows "investigat[ing] and explain[ing] the decision process by which various initial conditions are translated into outcomes".

Translated in methodological terms, the research design proposed by Tsoukalis that I have reassessed in this dissertation resembles the method of "systematic process analysis" 
offered by Hall (2003). With reference to the process under investigation, this method starts by elucidating the various theories that explain the causal factors and how they operate. In my case, I will identify the traditional theories explaining European integration. The second step will consist of deriving from each theory the causal patterns that should be observed if the theory is valid.

The most important merit of using "historical narratives" (Büthe 2002) is that it allows the contextualization of the different stages of a given process, such as - in my case - economic and monetary integration in Europe since WWII. Hence, this approach provides a better understanding than studies that take into consideration only specific periods of a given process. Subsequently, process tracing removes any doubt of a possible bias in case selection, since the time span under investigation coincides with the overall duration of the process being investigated.

Furthermore, in line with Bates et al. (1998: 11), I try to "seek to understand the actors" preferences, their perceptions, their evaluation of alternatives, the information they possess, the expectations they form, the strategies they adopt, and the constraints that limit their actions". Similarly, George and McKeown (1985: 35) argue that "[t]he process-tracing approach attempts to uncover what stimuli the actors attend to; the decision process that makes use of these stimuli to arrive at decisions; the actual behavior that then occurs; the effect of various institutional arrangements on attention, processing, and behavior; and the effect of other variables of interest on attention, processing, and behavior". In my research design, the actors being studied are $\mathrm{ECC} / \mathrm{EU}$ member states' governments and $\mathrm{ECC} / \mathrm{EU}$ institutions.

There are not only advantages but also limitations that come with the adoption of process tracing. The risk of using such broad research in attempting to explain the overall EMU 
development adopting a single theory - federalism -, has some implicit risks and caveats. First, it is almost impossible in the writing of a dissertation to take into account all the political, policy and polity ramifications of EMU, but the empirical chapter will offer a broad overview on what I see as the major federalist elements of EMU. Secondly, the idea that any institutional and political evolution that has taken place in EMU can be explained by a theory is an ambitious goal that could generate a vague overstretching concept and a sort of "theoretical reductionism" in order to force the theory to fit the empirical facts, or "empirical reductionism" where facts are forced to fit the theory.

Another problem is the possible existence of "micro-events" that could temporarily falsify the macro-theory and generate problems of internal validity, defined as the approximate truth about inferences regarding cause-effect or causal relationships (Trochim 2005). The label "micro-events" should not be confused with "minor events". Actually, they often represent major events. Thus, "micro" refers to the temporal length of the event (usually months or years) which is "micro" if compared to the overall duration of EMU integration process which has been going on for seven decades.

One example of micro-event is the failure of the Werner Plan in 1971 (event one) which elicited a temporary return to domestic politics in the first half of the 1970s (event two). However, that failure ultimately triggered further integration in the second half of the 1970s with the creation of the European Monetary System (event three). If the causal analysis is narrowed to events one and two, it might contradict federalism, but the inclusion of event three finally rescues it. Another example is the Snake, which limited fluctuations between different European currencies, de facto pegging all of them to one another. If taken singularly, the Snake could be analyzed as an example of variable-geometry policy granting a certain degree of flexibility and 
thus rescuing domestic executives from excessive centralization of monetary policy (see Moravscik 1998: 320; Kölliker 2006). However, if the Snake is put into a larger context, it was the first step of a centralizing trajectory interlocking monetary policy of EEC members. In fact, the Snake initiated in 1972 to limit fluctuations among European currencies against the US dollar, which 1979 allowed the creation of the EMS in, a system controlling EEC member's currency realignments and de facto working over ten years as a quasi fixed-rate system (Kenen 1995). This ultimately permitted the achievement of an irreversible locking of European currencies in 1999, and obtaining the single currency in 2002.

\subsection{The Structured Focused Comparison and Data Collection}

Chapter 5 introducing the mainstream theories already adopted to explain EMU is developed using a comparative perspective, identifiable with the structured focused comparison developed by George and Smoke (1974), George (1979) and George and Bennett (2005), which complements the abovementioned process tracing. In 1979 George invented the term "structured, focused comparison" to refer to a qualitative method to be adopted in small-N research. The method is "focused because it deals selectively with only certain aspects of the historical case" (George, 1979: 61). In my case, the case narratives and comparisons of my research design are centered on the conceptualization of policy, polity and politics, across four different integration waves. It is "structured because it employs general questions to guide the data collection and analysis in that historical case" (George, 1979: 62). In my research design, the general question is whether or not federalism can provide a satisfactory explanation of the overall history of 
European monetary integration. In more details, I use EMU as the case study to test various integration theories, including federalism.

Concerning the topic of this dissertation, it lies at the crossroads of three different subfields of political science: comparative politics, as I have already said, but also international relations, and political theory. These three subfields are taken into account in various degrees. The first and most important aim is to analyze "how" EMU has been politically developed, how policies have been implemented, and how the polity has changed over the decades. In this regard, the comparison of the various theories attempting to explain EMU (and the inclusion of federalism) places this dissertation in the comparative politics field. In fact, I assume that federalism is the mechanism through which EMU operates. Further, since what is being compared is meta-theoretical, a considerable degree of political theory is manifest as well. If we accept that the theories developed to explain European integration belong to the subset of political theory, then this dissertation can be considered an example of comparative political theory. Finally, given that integration theories inevitably rely upon the assumptions found in international relations, I consider in great detail the multi-level structure where integration dynamics take place, especially when I will define in chapter 5 three families of theories: statecentric, mixed and supranational. At the same time, international relations shed light on the causes of the existence of EMU ("why”).

As for research technique I adopted to collect data, the preliminary stages of my conceptual design initiated with a broad secondary research to determine what was known already on the correlation between EMU and integration theories. Secondary sources I scrutinized include scientific literature, newspaper, magazine and journal content. I noted that the literature already written on EMU from a theoretical perspective can be divided in "three 
waves": early theorizations up to the 1980s; a second wave from the 1990s examining the progress towards EMU and its achievements since 2002; and contemporary studies taking into account the reverberations of the current crisis on EMU integration.

After I had gained some insight into the issue, there followed primary research consisting of a collection of original data. I accomplished it through the analysis of official documents and original reports produced on EMU over the years by EEC/EU institutions, European governments, and think-tanks advising and researching on economic and monetary integration. Further, additional unstructured interviews were conducted with technocrats, scholars, diplomats, and policy-makers with a high degree of knowledge on EMU (see appendix for the list of people interviewed). 


\section{Defining Federalism and its Application to EU studies}

\subsection{Introduction: a Multidimensional Concept}

Federalism is a multifaceted term. In an influential work on federalism, Duchacek (1987) observed that there is no particularly acceptable, wide-embracing theory of federalism. For Watts (1998:120), a federal political system is a genus to which different empirical species belong. Similarly, Studlar (2010) argues that there is no generally understood and comparative terminology in discussing federalism, even among leading theorists in the field, due to the different institutional and policy configurations among federations. Further, Burgess (2006) observes that depending on historical backgrounds, federalism can be defined in many ways, even contradicting one another.

This chapter is intended to provide a general discussion of the various historical understandings of federalism, before my specific analysis of how federalism applies to EMU in chapter 6 . The first broad understanding of federalism is a value-neutral academic theory, as I will delineate in the next section; secondly, it represents a normative and ideological political concept adopted in European politics (section 3.3); and finally federalism can be considered an empirical practice originally realized in the United States that has been used by

scholars of European studies as a model applicable to analyze the integration path occurred in the European Economic Community and in the European Union (section 3.4). 


\subsection{An Academic Theoretical Approach}

From a theoretical perspective, I include federalism in the realm of mixed paradigms, since it takes into account both domestic and supranational factors. This assumption is not consolidated in the debate and should not be taken for granted. For instance, some authors such as O’Neill (1997) understood federalism as a supranational approach. However, since I define federalism (see chapter 6) as an institutional and legal polity in which EU and domestic inputs (broadly defined as politics) dialectically determine the rules of the EMU game, EMU institutions, and EMU policy, I believe it should be considered a mixed paradigm.

This assumption is legitimized by the fact that the first broad and approximate definition of federalism both as a theory and as a practice generally denotes the existence of two independent levels of political authority in a country, aimed to produce policy. A central government is responsible for the entire country, and sub-central governments are held accountable for the governance of specific jurisdictions in the country, with each performing a role in the policy process. A legal or constitutional system is established, together with the judiciary power to resolve jurisdictional disputes. For Auer (2005: 419), federalism consists of "a specific combination of self-rule (autonomy), of limited rule (superposition) and of shared rule (participation), implying the coexistence of two independent levels of government acting simultaneously on the citizens". For Watts (1998: 121) a federation is a constitutional, vertical allocation of authority, since it combines "constituent units and a general government, each possessing power delegated to it by the people through a constitution, each empowered to deal directly with the citizens in the exercise of a significant portion of its legislative, administrative, and taxing powers, and each directly elected by its citizens". 
Additionally, Obinger, Leibfried and Castles (2005: 8-9) have given five broad views that purport to explain variations of federalism. These are (1) a set of institutional arrangements and decision rules at central government level for incorporating territorially based interests; these arrangements vary in the degree to which they provide veto powers to subordinate branches of government; (2) a set of territorially based actors with ideas and interests who vary greatly in number and heterogeneity; (3) a set of jurisdictional arrangements for allocating policy responsibilities between different levels of government; this refers to both policy-making and policy implementation; (4) a set of inter-governmental fiscal transfer arrangements; (5) a set of informal arrangements - both vertical and horizontal - between governments.

Similarly, Siaroff (2005:162-163) argues that a comprehensive definition of federalism should encompass the following; (1) two autonomous levels of government - central (federal) and regional - with each being directly elected and accountable; (2) a formal division of authority specifying the powers and sources of revenue held by each level of government, as well as the level which holds the residual powers; (3) a written constitution which, among other things, sets out the respective powers of each level of government and which can only be changed with some difficulty; (4) a supreme court to arbitrate between the central and regional governments when there are disputes over whether one level of government may act in a certain way; (5) a bicameral legislature in which the lower house represents the people as a whole but the upper house represents the regions or the people in each region.

Analytically, there are various subsets of federalism. Vertical federalism denotes the allocation of power between the central government and the constituent units. Whereas this allocation of power can occur in various ways, generally in a federal system there is a balance of competences between the two levels (Buonanno and Nugent 2013). From this standpoint, I argue 
that MLG can be seen as a broader view of federalism, as a general theory and as a specific approach utilized to explain the EU. This assumption makes sense since federal systems have been already extensively depicted as multi-layered systems. In this regard, McKay (2001) observes that once the EU was defined as a multi-level system by Hooghe and Marks (2001), it followed that it could be compared to federal systems. A similar consideration has been made by Börzel and and Risse (2000) and Nicolaidis and Howse (2001). Kelemen (2004) argued that MLG initially was developed to explain policy developments in the EU, which increasingly has been viewed as a federal or quasi-federal system.

Horizontal federalism (Zimmerman 2011) focuses on the relationships between constituent units with minimal involvement at the central level. In the US, the aspect of horizontal federalism (or confederation) is not very prominent and is executed primarily by the National Governors Association and the National Conference of State Legislatures. Horizontal federalism is usually associated with the concept of Confederation. According to Watts (1998:121), in a confederation "the institutions of shared rule are dependent on the constituent governments, being [the institutions of shared rule] composed of delegates from the constituent governments". The historical model of confederalism as proposed by Forsyth (1981) closely resembles intergovernmentalism because states decided to associate voluntarily, given the common interest in building larger polities and markets. It derives that the European Council can be reinterpreted as fitting the model of a confederal international executive. Unlike in the US, thus, the EU intergovernmental negotiations resembling horizontal federalism or confederation are very important. For O’Neall (1996), a confederation may be considered as a peculiar type of intergovernmental arrangement, in which domestic sovereignty remains intact despite the setting of a common institutional framework. Warleigh (1998) argued that confederalism complements 
intergovernmentalism, by acknowledging the institutionalized character of the European Community. Confederalism as a way to promote institutional federalization has been extensively analyzed by Elazar (1987). Also, for Tsoukalis (1977) the confederal phase is characterized by the progressive loss of sovereignty at the domestic level in favor of the emerging central authority encapsulated in the federal structure. Other than intergovernmentalism, I argue that another concept introduced in EU studies which closely resembles confederalism is bottom-up Europeanization, which is defined as the member-states' development of institutions and governance at the EU level (Olsen 2002).

Dual federalism or "Layer cake federalism" was introduced by Grodzins (1966) to define a system in which the powers of the government hierarchy are clearly spelled out and kept separated. Ideally, the central government deals with broad domestic issues and foreign policy, while states deal with local issues, with little or no interference between the two arenas. Cooperative federalism or "marble cake federalism" defined by Grodzins and Elazar (1984) occurs when cooperative partnerships between federal and state governments are put into place. As a result, in various degrees the layers of government are mixed together.

Symmetric Federalism takes place where there is no distinction between constituent states. Asymmetrical federalism occurs when several constituent units possess different powers, like more autonomy or specific rights than other constituent units, although they have an identical constitutional status (Watts 1999; Brown 2005). This model is adopted to prevent social discontent or political unrest when several constituent units belonging to a federation are recognized to be different from the others, due to a cultural, ethnic, or linguistic difference. An extreme case of an asymmetric federation has been defined as Federacy by Stepan (1999), which represents a midway between unitary and federal states. 
Constitutional federalism denotes a constitution defining the constituent units of the federation, detailing the distribution of power between the latter and the central unit, and providing for a conflict resolution scheme between the two levels (Auer 2005). The mutual obligations among constituent units as co-equals, also known as comity or legal reciprocity, is one of the provisions that comes with being part of a federation (Buonanno and Nugent 2013). In contrast, less reliance on litigation and judicial interpretation denotes discretionary federalism (Kelemen 2004) since written laws work as a general framework permitting a certain degree of flexibility in application by the lower-level jurisdiction, usually that of constituent units.

As suggested by Musgrave (1959) and Oates (1972), Fiscal Federalism lays out a framework for the assignment of proper fiscal instruments at the various levels of government in line with the functions they are constitutionally authorized to carry out. Since the central government should have the responsibility for macroeconomic control of the federal economy together with monetary policy and control over exchange-rates of the federal currency - it derives that the central government should be entitled to a certain degree of fiscal prerogatives, to be shared with constituent units.

From an economic perspective, Viner (1950), Tinbergen (1954), Meade (1955), and Balassa (1961) identified a stage-based integration model whose path, logic and goal resembles a form of Economic Federalism. The first step is the creation of a free trade area made possible by the removal of internal tariffs, followed by a customs union (common external tariff), common market (free flow of capital, labor and services), economic union (harmonization of social, economic and sectorial policies), monetary and fiscal union (single currency and harmonized tax code), and political union (a federal state with an internal and external security apparatus). 
A plethora of comparative studies (cf. Elazar 1987; Burgess and Gagnon 1993; Hueglin 1995; Burgess 2006; Hueglin and Fenna 2006; Menon and Schain 2006; Pagano and Leonardi 2007), argue that federalism is an institutional arrangement searching for a common decisionmaking framework designed to ensure unity by allowing a certain degree of decentralized subcentral distinctiveness. This variation among constituent units has attracted the attention of several scholars. Compound Federalism defines the US (Ostrom, 1987; Brzinski, 1999) and the EU (Fabbrini 2002) as a union of States constituted by units of different demographic size, political history and geographical interests, and as such is necessarily characterized by different views on its constitutional identity. For Ostrom (1987: 106), a Compound Republic is "a polity constituted by concurrent and overlapping units of government" or better is "a system of government with multiple centers of authority reflecting opposite and rival interests (...) accountable to enforceable rules of constitutional law" (Ibidem: 21). This classical definition closely resembles a generic federal political system.

In this way, compound federalism is able to explain the multifaceted domestic preferences of EU members, encapsulating them in a federalist structure. Concerning the frictions between the EU and its member-states highlighted by state-centric theorists, Tsoukalis (1977) and Majone (2004) already emphasized that in a federalist structure, both in the setting of the rules and in the execution of the policy, a sort of antagonistic relationship emerges between the federation and the various jurisdictions taking part of it. From this point of view, the existence of tensions in the embryonic prefederal phase, as well as in a consolidated fully federal system, are not to be seen as something unexpected or exceptional. This is because the transfer of sovereignty from a domestic to a supranational context is always a contentious process, since countries try to safeguard their sovereignty, while the federation is conversely trying to extend its authority as much as possible. This is a more sophisticated explanation than those offered by state-centric paradigms. 


\subsection{A Normative Political Concept}

Federalism as a political concept has normative and ideological implications, since political advocates of federalism (in the EU often called "supranationalists") generally want a balance of power between two layers of government. As a political movement and political philosophy, the meaning of federalism varies considerably. Historically, being a "federalist" in the US and Australia meant to advocate for the creation of a stronger central government. In the case of the US, during the critical years 1781-1789, this bottom-up dynamic was necessary to increase the powers of the central government that were very limited if compared to the excessive governmental authority of the individual states. Similarly, federalists in EU politics are those calling for more centralization of powers at the EU level, given the former history of absolute sovereignty by individual European countries. Whereas in Italy, post-WWII Germany, and Spain after the restoration of democracy, federal movements have requested and achieved top-down decentralization of former centralized systems, defined as the transfer of powers from a too powerful central government to local authorities (such as provinces, regions, or districts). In both cases, the final result is a balance of power between two layers of government.

Federalists and neofunctionalists expressed their enthusiasm about promoting further integration beyond domestic boundaries. As such, federalist supporters and politicians were pushing for a federated Europe with as much as possible evolution of powers towards the communitarian institutions. Dyson (1994) noted that after WWII support for European integration came from a new generation of politicians who had directly experienced the horrors of two world wars fought on European soil. With the sole exception of Paul-Henry Spaak, Belgian prime minister (1948-51) and foreign minister (1948-51, 1954-7, and 1961-6), they were 
Christian Democrats, such as Konrad Adenauer (German Chancellor 1949-63), Robert Schuman (French Prime Minister 1947-8 and Foreign Minister 1948-52), and Alcide De Gasperi (Italian Prime Minister 1945-53). As noted by Dyson "federalist politicians were far from able to use their will indiscriminately $[\ldots]$ but they represented a new climate of ideas that was to prove a potent new factor" (Dyson 1994: 59).

The most prominent federalist movements after World War II admired US institutions and attempted to emulate dimensions of it. The "Ventotene Manifesto for a Free and United Europe", written by Altiero Spinelli and Ernesto Rossi while serving in a penitentiary as political prisoners during WWII, was a theoretical pamphlet discussing the economic and political unification of Europe from a federalist perspective and by a federal constitution (Spinelli and Rossi 1944). In the aftermath of WWII, the Union of European Federalists (UEF) met for the first time in 1946 near Zurich in Switzerland moved by the belief that only a European Federation based on the idea of unity in diversity could preserve peace in the continent. Another important document produced in that period was the Resolution of the Congress of Europe in 1948 (also known as the Hague Congress) which was a short political program calling for the creation of "an economic and political union in order to assure security and social progress" (Congress of Europe 1948).

Some of these federalist supporters, such as Jacques Monnet and Robert Schuman, theorized an incremental and steady transfer of sovereignty towards the EEC, while another school of thought, led by Spinelli, argued for a "big bang" solution with immediate and allembracing empowerment of communitarian institutions via constitutional reform (Spinelli and Rossi 1944). Monnet was a very proactive supporter of a federated approach to the extent that in 1955 he resigned as President of the High Authority of ECSC after France had refused to ratify 
the European Defence Community (EDC), thus certifying the impossibility of having any kind of integration in defense, at least in the short term. After the failure of EDC, in 1955, Monnet founded the Action Committee for the United States of Europe in order to revive the federalist approach as a rationale for European integration. Both visions were represented within the UEF, but in 1956 it split in two distinct organizations: the "Mouvement Fédéraliste Européen" (MFE), bringing together advocates of the constitutional approach, and the "Action Européenne Fédéraliste" (AEF) formed from those supporting a gradual approach. After the achievement of the customs union, in 1973 the two organizations reunited and the UEF was reestablished. The result of federalists' activism was the successful campaign for the direct election of the European Parliament. Still today, federalism is debated in media, academic, and political circles. The UEF and other organizations are advocating for a Federal Europe through the organization of seminars, think tank and various events aimed at make the public opinion aware about the advantages of pursuing more integration.

The first generation of federalists has been succeeded by later supporters that made the evolution towards the European Union possible. For instance, political leaders such as Roy Jenkins and Jacques Delors, acting as presidents of the European Commission respectively in the 1970s and in the 1980s, represented a major force in the integration process, as I will elucidate in details in chapter 4. In doing this, they were supported by an epistemic community of technocrats and civil servants supporting the idea of a federal Europe from ideological and philosophical perspectives. A well-known definition provided by Delors and developed by scholars in a more theoretical fashion is the EU as a "Federation of Sovereign States" upon principles borrowed from the Articles of Confederation of the US (Nicolaidis 2006). This oxymoronic definition of 
the EU is intended to identify the interlocking relationship between domestic factors and supranational impulses.

\subsection{Applied to EU Studies}

Federalism is a theory and a normative framework, as well as an empirical artifact, since in the world there are 26 officially existing federations distributed across all six continents. These include advanced industrialized countries and developing countries, democracies and authoritarian states. This being said, it is nearly impossible to convey the dynamic of any federal system without comparing it to the United States, the first and foremost historical example of federalism.

Looking more specifically at Europe, this comparison makes particular sense for at least two reasons: the first one is that the US has represented a federalist model for European integration not only in the past but also now, not only in good but also in bad times, as I will explain later. Furthermore, from an international relations perspective, the US got involved in European affairs after WWII pushing for a European integration project to ensure reconstruction, peace and prosperity in countries devastated by years of war. Hence, the US hence exercised an

idealistic but also pragmatic influence for Europeans. As I will explain in detail later, the U.S. Marshall Plan (1947-1951), officially the European Recovery Program (ERP), required European countries to cooperate in order to get the financial aid that they needed to rebuild their economies.

The division of competences between the EU and its member states in a multilevel political system has represented an ideal case for scholars to apply the concepts of federalism, 
confederalism, or federalization. As such, those investigating federalism from a comparative perspective do not see the need to define the EU as an exceptional system. They contest the idea that the institutional structure of the EU is unique, as supporters of Europeanization theory claim (Dyson 2000a, 2000b, 2002, 2007a, 2007b, 2008). In this regard, scholars have used federalism as a comparative concept in order to describe the features of the EU in comparison to existing federations, in particular with the U.S. and Switzerland (Cappelletti, Seccombe, and Weiler 1986; Sbragia 1992; McKay 2001; Nicola1dis and Howse 2002; Börzel and Hosli 2003; Fabbrini 2005; Trechsel 2005; Menon and Schain 2006).

Especially since the 1990s, a number of researchers (cf. King 1982, Rhodes and Mazey 1995; Watts 1998; McKay 1999; Weiler 1999; Fabbrini 2005; Burgess 2006: 226-245; Menon and Schain 2006; Dosenrode 2007; Leonardi and Nanetti 2007: 288-304) have envisioned the EU as a form of federalism. These authors share the idea that the organization of the EU is based upon the existence of a voluntary union with a central authority created by its member states. Under this theory, institutions promoting the EU interests and prerogatives such as the European Commission, the Parliament and the Courts constitute this centralized sphere, whose predominance is counterbalanced by institutions defending member-states' interests, through the intergovernmental (or confederal) method. Taken together, the decision-making shared between these two types of institutions denotes what an empirical federation is.

The EU can also be seen as an archetype of confederation. According to Forsyth (1981) and Burgess (2000), the main confederal institutions of the EU are the non-frequent intergovernmental conferences of the European Council, composed of the governments of the various member states. In addition, from a policy perspective, depicting the EU as a confederation is still persuasive for policies still mostly managed at the domestic level, such as 
foreign policy and taxation. The political reverberation of this situation is that members still want to retain an almost exclusive sovereignty on several sensitive policies, where the EU has little or no legislative power and no power of judicial review.

As noted by Fabbrini (2002), the European Union is certainly the most advanced experiment of supranational integration in the contemporary world but whether it is a federation or a confederation is controversial because in the EU it is not possible to draw a clear distinction between the two theories, since both appear to be present in the EU case, even if the boundaries between the two are not pristine. There are few doubts that the EC started as an international organization in the 1950s. However, as noted by Fabbrini (2002: 6) "the EU has since then gradually reduced its original intergovernmental configuration to acquire more the features of a supranational organization, without acquiring nevertheless the features of a full blown federation". In synthesis, the coexistence of both confederal and federal genes is compatible and able to correct the limits of both models. On the one side, confederalism was necessary at an early stage to make the integration possible without threatening the sovereignty of members. On the other side, federalism allowed a centralized execution of policies integrated at the supranational level, like economic and monetary integration. Not surprisingly, this trajectory is similar to what happened in the United States. With specific reference to the EU, others suggest that a full shift form a confederation to a federation is detected by the longitudinal concept of "emerging federalism" (Macmahon 1962), federalization (Trechsel 2005), would-be federation (Bendnar, Ferejonh and Garrett 1997) and "federal integration model" as suggested by Buonanno and Nugent (2013), merging the economic federalist theory as suggested by Balassa (1961) with a political perspective. 
Some other scholars have highlighted that the EU is a type of regulatory federal organization that dictates the actions of its members in several policy areas (Sbragia, 1992; Majone 1996; Castles, 1998; Cowles et al. 2001). According to Sbragia (1992), the rising power of the EU in the economic policymaking process of its members makes the EU a quasi-federal system since economic centralization is balanced with regional diversity in other policies. For Kelemen (2004), in environmental policy, within a federal framework, the EU acts as a regulatory polity that ensures that members comply with its environmental directives. Kelemen (2004) further notes that similarly to other federal systems, such as Canada, Germany, and the United States, in the EU most of policy decision is done by the EU Commission, while member states are principally responsible for policy implementation. Auer (2005) argued that from a legal standpoint, the EU meets every condition to be considered as a multinational federal type construction.

\subsection{Conclusion: Filling a Theoretical Gap}

With reference to European monetary unification, two kinds of brief sui generis sources adopting a federalist focus are available. The first one widely reported in the media and incidentally by scholars, refers to EMU as a kind of "common sense" federalism, since the circulation of euro across Eurozone members can be considered one of the most visible examples of a federalizing EU. For Burgess (2006:80), "the drive toward the Economic and Monetary Union (EMU) is unquestionably a political imperative and constitutes yet another incremental step on the road towards a federal Europe. According to Fabbrini (2005:119), "the Euro exerted further pressure on the EU to become a supranational polity, rather than, or 
more than, an international organization". The second kind of sources examines a little bit more extensively the correlation between EMU and federalism from very diverse angles, especially from a historical perspective (Crawford 1996: 338 - 365; Pinder 1998: 142-181; Burgess 2000; McNamara 2003: 253 - 269) or referring to the European Central Bank (Jabko 2006: 275-291). However, despite these observations, surprisingly enough the possibility to analyze the EMU as a case of institutional federalism seems not to be investigated in-depth by mainstream literature dealing extensively with the topic of EMU and European integration (Verdun 2002; Dyson 2000a, 2000b, 2002, 2007a, 2007b, 2008).

Attention towards federalism is on the rise again in media, academic, and political circles after years of relative obscurity. Several press reports and editorials calling for a revived vision towards the "United States of Europe" appeared in the press (Urdank 2012), legitimizing the plausibility of the federalist approach, especially when applied to EMU. A conference organized in March 2012 by the Centre for European Policy Studies (CEPS) hosted academics and policy-makers who discussed the euro and economic governance from a federalist standpoint. From a scholarly perspective, Nugent and Buonanno (2013) recently released a specific chapter on EMU interpreted as a case of "federal integration model" merging the economic federalist theory as suggested by Balassa (1961) and a political perspective. Habermas (2013) as well made a specific reference to the current institutional reforms as an attempt to transform the system of European governance into one of "executive federalism". For Habermas this drive towards federalism is a mistake, because the postnational EU should evolve toward a cosmopolitan community. Translated to IR terminology, Habermas seems to take a constructivist stance, similarly to theorists of Europeanization who saw the EU as a regime with its own "exceptional" nature, and therefore in need of having 
specific theories to explain it (Dyson 2000a, 2000b, 2002, 2007a, 2007b, 2008). The rest of the dissertation aims to fill this theoretical gap.

\section{The Evolution of Economic and Monetary Integration in Four Stages}

\subsection{Introduction: a long Journey}

Since the goal of this dissertation is to explain the overall evolution of the EMU using federalism and to compare it to other explanations, a chapter dedicated to the complex narration of the process pertaining to economic and monetary issues is unavoidable. This historical chapter highlights long-term facts and processes functional to my federalist approach (presented in chapter 6), is the organization of the overall history of EMU in four phases:

(i) The onset of economic integration and the first experiments of monetary coordination (1950s-1968)

(ii) The steps towards a real common currency from 1979 to 1998;

(iii) Monetary unification in practice since 1999;

(iv) Euro survival under threat amidst economic and financial turmoil since 2010.

EMU is the last step on a long path toward EU economic and monetary integration. As such, while the theoretical interpretations of the EMU are still debated, the facts related to the evolution of the EMU since the 1960s have been well known by scholars up to recent years, at least until the ongoing financial and economic crisis which is unpredictably reshaping EMU. 
However, the aim of this chapter is to highlight several historical facts such as interplay from the very beginning between domestic and supranational factors in shaping EMU, an aspect often ignored by previous studies. I believe, in fact, that this interplay - sometimes neglected by authors while formulating their theories on integration -, is essential to explain EMU. In other words, when it comes to evaluating integration theories, I argue that mixed paradigms such as federalism, taking equally into account the role of both the EEC/EU institutions and the domestic politics of EEC/EU members, provide a better understanding of EMU. This is why this chapter is relatively rich and detailed, even if exclusively descriptive and historically-oriented. However, it provides the foundations on which the rest of the dissertation is laid.

Secondary sources dealing with the historic evolution of the monetary integration are variegated and written at different times (Tsoukalis 1977; Kruse 1980; Louis 1990; Ungerer 1997; Lieberman 1992; Cobham and Zis 1999). More recently, authors have dedicated specific chapters depicting, in various degrees, a concise introduction to the broad historical evolution of the monetary integration (Dinan 2005; Hosli 2005; Van Oudenaren 2005; Verdun 2010; Hix 2005; Hix and Høyland 2011). Some other pieces illustrating the evolution of monetary integration are more theoretically oriented: Moravcsik (1998) argues that the overall EMU project is a case of intergovernmentalism in action, whereas Pinder (1998) opts for a sort of confederal view, and Dyson (2000, 2002a, 2002b) applies Europeanization approach. The analyses provided by the latter group of authors represent the focal point of this dissertation, hence they will be discussed more in chapter 5 dedicated to the review of the theories explaining the evolution of EMU.

Generally, primary sources are important as well. Official legal documents are regularly published in the Official Journal of the European Communities and are available online on the 
World Wide Web. However, early documents which did not achieve legal status were published in the "Compendium of Community Monetary Texts" published by the Monetary Committee of the EEC/EC for the first time in 1979 and updated in 1989 and 1994, and in "Texts concerning the European Monetary System" published in 1979 and updated in 1985 by the Committee of Governors of the Central Banks of the European Communities and by the European Monetary Co-operation fund.

Obviously, most of these sources will constitute not only the basics for this historical overview but most importantly the pillars of the following literature review and will be reviewed in detail in order to highlight my explanation based on federalist theory. Several pieces cover the overall trajectory of the EMU up to the 2000s, and the latest editions already provide accounts and analyses related to the current turmoil affecting the eurozone and the overall EU (Hix and Høyland 2011). Other studies pay attention to more limited issues, looking at the evolution in a particular time span (Dyson 1994), highlighting history-making decisions (Dyson and Featherstone 1999) or considering the role of specific actors such as countries or leaders' attitudes (Verdun 1998).

A growing strand of literature (Talani 2009; Hogson 2011) analyzes the causes and the consequences of the crisis, reorienting the current debate towards the survivability of the Euro itself. However, no detailed studies are yet available using an integrationist focus on the proposed solutions to tackle the crisis of the eurozone. In this regard, I will attempt to explain these solutions - Fiscal Compound, Stability Mechanism, and Budgetary Discipline Enforcement - as prototypically federalist. Further, concerning these contemporary issues, I will take into account press and media coverage. In fact, especially for the Financial Times, the Economist, and the New York Times, the economic and financial turmoil that hit hard 
several EU members proved to be an interesting topic which was (and still is) followed closely on daily or weekly basis.

\subsection{The Onset of Economic Integration and the First Experiments of Monetary Coordination (1950s-1968)}

At the very beginning, the integration of economic and monetary policies was disjointed. On one hand, in the aftermath of World War II, economic integration (together with security) was the very first rationale of European integration for the six founding members (von Hagen 2013). In this regard, the establishment of the European Economic Community in 1957 by the Treaty of Rome represented the embryonic act which initiated the long, political and legal path towards economic integration, to be fully achieved in future with the potential economic union. Another area on which the political energy was diffusedly spent by both EEC institutions and ECC member states was the realization of a Common Agricultural Policy (CAP). On the other hand, progress towards monetary integration in the 1950s and in the 1960s was much more limited, but several achievements and principles elaborated at that time would constitute the basis for the remarkable evolution towards a common currency that has taken place since the 1970s.

There were several reasons limiting any successful discussion concerning the idea (not to mention the execution) of a common currency. First of all, the Bretton Woods agreements signed in 1944 provided the international framework centered around the US dollar as the undisputed monetary standard that took over the role that gold had played under the gold standard. The system was designed to stabilize the relative value of the currencies of prominent Western countries against each other and did not create any urgency to push for a pan-European monetary 
integration (Louis 1990). In order to accomplish this task, members of the IMF were required to establish a parity of their national currencies in terms of the reserve currency (a "peg") which was the US dollar. They also had to maintain exchange rates within a limited fluctuation (a "band") agreed to be plus or minus 1\% of parity. As observed by Bordo (1993), Bretton Woods evolved into a de facto fixed exchange rate regime. In order to minimize their own currency fluctuations and to keep the exchange rates within the agreed band, countries intervened in their foreign exchange markets by buying or selling US dollars. Ultimately, Bretton Woods established a system of payments based on the US dollar, itself convertible into gold. The design of the Bretton Woods System was that countries could only enforce gold convertibility on the US dollar (Mulhearn and Vane 2008). Furthermore, as noted by Tsoukalis (2003), domestic currencies for European countries represented a sensitive national symbol, and finally, the monetary policy was considered an unquestionable tool necessary to adjust the domestic economy.

In the earlier stages, hence, the US constituted one of the factors promoting European integration. As noted by Tsoukalis (1977) an important external factor - which Dyson (1994) appraises as "structural" - encouraging economic integration in Europe and finalizing security and peace in the continent was the role played by the United States in the Old Continent, achieving the status of an economic superpower after WWII. The role of the US in post-WWII is exemplified by the Marshall Plan (1947-1951) that required European countries to cooperate in order to get the financial aid they needed to rebuild their economies.

Hitchcock (2010) argued that the impact of the plan extended much further than the narrow scope of financial aid. Strategically, the integration of Western Europe was seen as functional in order to build a solid bloc opposing the Communist domination in Eastern Europe. 
Similarly, the US supported the idea to avoid at any cost the isolation of West Germany and, as such, include it in the integration project. From an economic perspective, Hogan (1989) argued that the Marshall Plan helped the economic reconstruction of Europe. However, for Hogan the main intention of US strategists in the long run was to shape Western Europe into a capitalist and integrated economy such as the US.

It is not a case that concurrently with the demise of the Marshall Plan, European countries initiated their own integration pattern with the Treaty of Paris (formally the Treaty establishing the European Coal and Steel Community) signed in 1951 and effective since 1952. The Treaty of Paris between France, Italy, West Germany, and the three Benelux countries (Belgium, Luxembourg, and the Netherlands), established the European Coal and Steel Community (ECSC) with the aim of sharing the production of two crucial resources that previously had been central to WWII.

From this standpoint, the US's role in Europe sheds light on the causes of the existence of economic integration ("why"). However, given the theoretical influence that US federalism and the federalization process exerted on many European politicians and intellectuals (as I have already highlighted in chapter 3), the US's interventionism and appeal in Europe after WWII explains also "how" an economic and monetary union has been engineered. Not surprisingly, in fact, the US Federal Reserve system constituted an inspirational model to develop a European common currency, since the integration processes in the US and Europe have shown striking similarities (Fabbrini 2005) despite obvious and inevitable differences (Dyson 1994: 31).

In 1957, the Treaty establishing the European Economic Community (TEEC, also known as the "Treaty of Rome") adopted a progressive approach towards economic coordination of the policies of individual members, to ultimately achieve a customs union by the end of the 1960s 
and a common market in the 1970s ${ }^{3}$. Also, the European Atomic Energy Community (Euratom) was founded in 1957 alongside the European Economic Community (EEC). The EEC and Euroatom basically replicated the same institutional architecture as seen in the European Coal and Steel Community (ECSC), already established since 1952. As a result, each community had its own institutions: (i) the supranational High Authority, a quasi-executive body representing the ECSC interests, promoting further integration, and empowered to be the sole initiator of legislation, (ii) the intergovernmental Council of Ministers representing members' interests which had to decide (mainly by unanimity) on the High Authority's bills and set ECSC goals (achieved by the High Authority), (iii) the Common Assembly, an appointed, not elected, body having mere consultation power, and (iv) the Court of Justice, sharing competences with domestic courts on ECSC issues. Further, even if the three treaties kept unanimity as the conventional voting procedure in the Council of Ministers, especially for the most important decisions such as Treaty amendments or overall policy directions, they paved the way to the Qualified Majority Voting (QMV) in certain restricted areas and under certain conditions on a proposal of the Commission and after the Assembly was consulted ${ }^{4}$. In 1966 the Merger Treaty (or Brussels Treaty) combined the executive bodies of the ECSC, Euratom, and EEC into a single institutional structure, even though the three communities were kept separate. The Merger

3 The Treaty of Rome has been amended four times, with the aim to expand the domains of economic integration and target monetary union. The First revision took place in 1986, when it was incorporated in the Single European Act (SEA). A second revision occurred in 1992, encapsulated in the Treaty Establishing the European Union (TEU), the third one in 1997 (Amsterdam Treaty) and the fourth one in 2000 (Treaty of Nice).

4 The Qualified Majority Voting weighted system (i) assigned votes in proportion to the population size of members, and (ii) required 2/3 of the votes to pass. As of it application, the Treaty Establishing the EEC laid out the detailed timing of policy decisions concerning economic integration. If no unanimity on these decisions was reached at the end of the last possible stage, in order to avoid stalemate the QMV was allowed in certain restricted areas of the Common Market, the prohibition of any economic discrimination based on nationality, duty reductions targeting the customs union, extraordinary authorizations for a member to apply tariff or quotas for troubled economic sectors, conditions of employment for employees and officials of the EEC. 
Treaty renamed the High Authority as the European Commission and further extended QMV procedure. (Van Oudernaren 2005).

The Treaty of Rome was somewhat ambivalent on economic and monetary issues, mostly working as a general framework introducing provisions to be elaborated more in details at a later time (Tsoukalis 1977; Ungerer 1997). On the one side, following a constitutional logic, at the very beginning in its most important section called the "Principles" (Articles $1-8$ ), the treaty clearly highlighted the progressive convergence of the economic policies of its members, the establishing of a common market, the provisions to pursue these two goals, and the division of powers among institutions. Also, the second part of the Treaty, clearly identified as "Foundations of the Community", identified several economic (and integrationist) principles such as the free movements of goods, the customs union, the elimination of quantitative restrictions, and the extension of trade in agricultural products. On the other hand, economic, monetary and exchange rate policies were encapsulated in Part Three ("Policy of the Community"), Title II ("Economic Policy"), and Chapters 1 (“Conjunctural Policy) and 2 ("Balance of Payments") ${ }^{5}$. Only seven of the 240 articles of the treaty (Articles 103-109) dealt explicitly with these issues. Given the subsequent (and more recent) development of monetary integration, it is worthwhile to briefly outline the most important monetary provisions already contained in the original Treaty of Rome:

- Article 103 declared that "Member States shall regard their conjunctural policies as a matter of common concern". Ungerer (1997) noted that "conjunctural policies" was a term translated from the German "Konjunktur-politik" and from the French "politique de

\footnotetext{
5 Balance of payments accounts are an accounting record of all monetary transactions between a country and the rest of the world (Sloman 2004:555-559). The policies included in the Treaty of Rome were competition, economic policy, commercial policy, social policy, and development policy through the European Investment Bank.
} 
conjuncture". It could mean short-term economic policies as well as broader monetary policies. In real terms, the obligation of consultation was weak, not to mention coordination, hence the domestic economic policies of the six members remained almost untouched and the Council generally released recommendations or resolutions such as, for instance, the recommendation in 1964 to reestablish internal and external equilibrium to deal with inflationary pressures (Official Journal of European Communities 1964: 1029-31). In 1960, the Council agreed to set up a Short-Term Economic Policy Committee to help the Commission to oversee the application of Art. 103.

- Article 104 stated that each member had to pursue the economic policy needed to ensure the equilibrium of its overall balance of payments and to maintain confidence in its currency, while taking care to ensure a high level of employment and a stable level of prices. This meant the pursuit of internal and external monetary stability, a difficult task that could be achieved only by manipulating the exchange rate. This, however, was considered detrimental for the maintenance of a common customs or common market (Ungerer 1997).

- Article 105 affirmed that to promote coordination in the monetary field for the functioning of the common market, a Monetary Committee was set up. This committee was composed by two representatives for each member (usually one from the economic ministers and one from the central bank) and two representatives for the Commission. According to the Rules approved by the Council on 18 March 1958, the main purpose of the Monetary Committee, which was supposed to work independently from domestic politics, was to keep under review the monetary situation of members, to give advice and 
provide opinions to the Council and the Commission. It was not, however, vested of any substantial power. Only over the years, the Committee acquired an important policy role. Following a Council of Ministers decision of May 8, 1964, the Committee was granted advisory powers not only for intra-EEC monetary issues but also for international monetary policies of the EEC.

- Article 106 declared members' readiness to undertake the liberalization of payments connected with intra-Community trade, a principle aimed at removing the restrictions of the movement of capital between members, which had been already promoted in 1950 outside the ECC framework through the European Payments Union (EPU). When in 1958 the full convertibility of all EEC currencies was restored, this article became somewhat redundant even though it worked as a safety net in case of economic difficulties of one of the EEC members (Ungerer 1997).

- Article 107 asserted that exchange rates were considered "a matter of common concern". As such, if a member changed its rate of exchange seriously distorting competition, the Commission could, after consulting the Monetary Committee, authorize other members to take the necessary measures to counterbalance the consequences of such alteration. The aim of this article was to limit the extent of competitive devaluations, a monetary strategy sometimes used by governments aimed at devaluating a currency to restore competitiveness for exports and inherently granting an advantage over other countries (Ungerer 1997). 
- $\quad$ Articles 108 and 109 determined that when a member had difficulties concerning its balance of payments, possibly jeopardizing the functioning of the common market, the Commission should immediately investigate the position of the member and recommend measures to be implemented. These articles set out procedures involving a complex interplay among the supranational Commission, the Council representing the members, and the advisory Monetary Committee. In the most severe cases the Commission could, after consulting the Monetary Committee, recommend to the Council the concession of mutual assistance (ranging from the temporary allowance of protective measures to the granting of credits by other members), which had to be decided by qualified majority. This article was enacted in 1968 at the behest of France experiencing a political crisis in May 1968 with economic repercussions, causing the eventual resignation of President De Gaulle (Ungerer 1997).

A brief analysis of these articles shows that they did not mention any explicit statement for a single currency or central bank (McNamara 2003). Rather, the Treaty of Rome paid more attention to pave the way for a common market, despite escape clauses for members experiencing economic troubles, and introduced the idea of solidarity in the form of ad hoc mutual assistance. However, it would be a serious error to dismiss the importance of the Treaty of Rome in both economic and monetary realms, since some of its provisions show affinities with subsequent developments (Ungerer 1997) and the actual course of monetary integration. In this regard, Padoa-Schioppa (1990: 9) noted that the Treaty of Rome had from the very beginning an indisputable legal status aimed at transforming economic rules in its members, even though the author had to admit that "in practice, coordination never went very much beyond polite ritualistic consultation" (Padoa-Schioppa 1990: 18). The problem of the discrepancy 
between written rules and real practices would represent a problem not limited to the early integration stages, as contemporary troubles show.

In such a framework characterized by the predominance of the US dollar and by the fear of any loss of domestic monetary sovereignty, Mulhearn and Vane (2008) observe that the only possible option promoting a certain degree of monetary cooperation was the European Payments Union (EPU) created by the OEEC in 1950, as it is reflected in Article 106 of the Treaty of Rome. Mulhearn and Vane describe EPU as a system that allowed countries with a trade deficit to transfer their liabilities to the EPU, which worked as a credit line which had to be ultimately settled in US dollars and gold. Simultaneously, economies in trade surplus received partial settlements in US dollar or gold. The EPU avoided the impulse to enact trade restrictions or barriers, which were discouraged by the economic boom and legally banned by several bilateral agreements convened between European countries after World War II. Essentially, the EPU provided a sort of multilateral umbrella to prevent market distortions, promote intra-European trade, and cope with the structural inconvertibility of currencies, with the only exception of the US dollar. Braga De Macedo and Eichengreen (2001) observe that EPU worked until 1958, when it was replaced by the European Monetary Agreement (EMA) a multilateral settlement which restored the external convertibility of members' currencies in the framework of the Bretton Woods system. According to Braga De Macedo and Eichengreen (2001), the EPU provided a model for the ERM code of peer-reviewed monitoring and for the coordination of stabilityoriented policy in EMU, since the EPU was a mechanism

"to exert peer pressure not unlike the one that is at the heart of the multilateral surveillance procedures of the Exchange Rate Mechanism (ERM) of the European Monetary System (EMS). Insofar as Europe's monetary union 
(EMU) is a descendent of the EMS, it can be said that the lessons of the EPU continue to be practiced today" (Braga De Macedo and Eichengreen 2001:1).

Concerning the legal system of hypothetical sanctions (Article 107), Pinder (1998) observed that the Community had few instruments to oversee violations, and procedures to investigate possible infringements were not pursued, since governments preferred to keep as much economic sovereignty as they could. Not surprisingly, the economic reports in the late 1950s of the first Commission lead by Walter Hallstein (who held two separate mandates from 1958 to 1967) did not really engage in the discussion of monetary issues, but mainly focused on the economic situation of the Community and its members. Robert Triffin (1958:1), an American monetary expert and one of the first architects of monetary integration, described the limited monetary dimension of the EEC Treaty as "a Hamlet in which the role of the Prince of Denmark is almost totally ignored". The Commission, in fact, had many more responsibilities and power to enact commercial and competition policies than it had in macroeconomic and monetary issues (Maes, 2006).

The writing of Article 107 was deeply affected by the Belgian delegation which, inspired by the Benelux customs union, successfully pushed for having the exchange rate among members' currencies considered as "a matter of common concern" and as such included in the area of competence of the Community (Van Tichelen, 1981: 340). The formula was certainly ambiguous, but it showed that from the very beginning decisions made in the Council were not only an exclusive matter for France and Germany and that a pooling of sovereignty was enacted in monetary affairs from the very beginning, even though mildly.

In order to solve the matter of mutual assistance, including the possible granting of credits (Articles 108 and 109), a European Reserve Fund (ERF) which would have given the 
EEC the status of a European Reserve Union, was proposed in 1958 by a proactive Hallstein Commission, in which the Frenchman Robert Marjolin was appointed as responsible for Economic and Financial Affairs and the German Leonhard Gleske was appointed as Director of Monetary Matters. As Maes (2006) made it clear, Marjolin, in collaboration with Triffin, one of the most influential economic advisors and collaborators of the federalist scholar and diplomat Jean Monnet, drew up a proposal for the ERF which could be constituted by pooling $10 \%$ of the international reserves of members' central banks. The ERF would provide loans to assist countries with balance of payments difficulties and also to support economic growth. Such a mechanism, based on a collective stance and put together following the EPU regime, was supposed efficiently to prevent currency speculation. Also, it made the role of the Commission more prominent in various ways: it gave a key role to the Commission in the macroeconomic and monetary area; and institutionally, a member of the Commission would be on the Executive Board of the ERF, together with the central bankers. At the end the proposal was not enacted, because in 1958 countries participating in the EPU restored the external convertibility of their currencies. However, the idea to promote financial solidarity among ECC/EU members would become a recurring theme on various occasions: during the discussion of the Barre Memorandum (Maes 2006), during the later proposals to reform the system of economic governance in the EU (Deroose, Hodson and Kuhlmann 2004), and during the economic and financial crisis affecting the eurozone since 2009.

The activism of the Commission (especially the commissioner responsible for Economic and Financial Affairs, Robert Marjolin), which wanted to find its way to expand their role in European integration, is reflected in the Commission's Action Programme for the Second Stage of the EEC (1962). Following the general framework provided by the Treaty of Rome, this 
memorandum was a very detailed document of ninety pages pushing towards the achievement of a full customs union (which was intended to be the first stage to be achieved in the period 19621965), a common market (second stage to be achieved in 1967) and a monetary union (third stage). The memorandum was exaggeratedly optimistic since in reality the customs union would be fully achieved in 1968, not to mention the common market and the monetary union, which would be established much later. Differently from the ERF which was an eminent monetary plan and as such very specific on the was intricacies of monetary policy, Maes (2006) observed that the Commission's memorandum did not include the ERS as a project, because the Commission pushed for the creation of the common market and a monetary union was seen as a logical and inevitable consequence of the common market.

On this issue, Andrews (2002) and Maes (2006) noted that the Commission pushed to interpret the Treaty of Rome in the most extensive way, and to press onwards to a fast achievement of an economic, monetary, and political union. The Memorandum took a functionalist stance, arguing that monetary policy was essential and inevitable to shield the customs union and the common market from financial turbulences provoked by exchange rate fluctuations, ambitiously arguing that fixed rates of exchange between members' currencies could become a target of the third stage of the common market (1966-1969). Further, the threestage approach introduced in the Memorandum, even if unrealized at that time, would become the conventional planning method followed at the end of the 1960 s by the Werner Report and later in the 1990s to achieve EMU. Nonetheless, the chapter drafted by the Commission on economic policy comprised both German and French preferences on various issues, showing that pursuing an economic union would not necessarily be conflicting with domestic preferences (Ungerer 1997). 
The memorandum proclaimed that an economic union would require fixed exchange rates between members. In addition, audaciously "interfering" with the sensitive issue of sovereignty, it openly invoked fewer domestic interventions in economic issues. In the words of the Commission (1962: 6):

\begin{abstract}
"[It] must be remembered that an economic order based on freedom can only exist in the world of today at the price of constant State intervention in economic life. Such intervention takes a twofold form: in the first place, the State sets up a framework of controls covering every branch of the economy as well as every adjacent field; secondly, it is constantly altering the factors called into play, through the innumerable adjustments involved in its day-to-day economic activity: in short, by pursuing a "policy" in the proper sense of the term.
\end{abstract}

The Commission also proposed the creation of a council of Central Bank governors, joint meetings of finance ministers to have coordinating discussions of monetary issues, and consultations on the execution of monetary policy. Furthermore, the memorandum called for the setting up of a more comprehensive institutional framework to facilitate economic cooperation through the establishment of additional committees, and asked for a formalization of procedures aimed at providing mutual financial assistance should a member experience economic troubles. After the establishment of the monetary union, the Commission believed that "[t]he Council of the Governors of the Banks would become the central organ of a federal type banking system" (Commission of the European Economic Community 1962: 67). Following Maes (2006), it is crucial to highlight that the Commission participated, as an observer, to the meetings of the Committee of Governors. This gave the Commission a closer look at the technical functioning of the central bankers. Most importantly, Jacques Delors serving as the Commissioner responsible 
for monetary matters participated in these meetings. It was in such an environment that Delors developed the belief that central bankers had to be central actors in the setting up of a monetary union. This assumption would be reiterated by Delors when he was successfully proposing the establishment of the European Monetary Institute in his well-known Delors Report, released in 1989 when he was serving as the President of the Commission (Committee for the Study of Economic and Monetary Union 1989).

Obviously, the ambitious pressures of the Commission pushing for a shift from a mere consultation to a substantial cooperation and finally to binding common policies and the concessions granted on paper by the Council were ambiguously opposed by the six members, this causing a de facto deadlock (Ungerer 1997). Especially in monetary integration, no tangible action was taken. Not surprisingly, the majority of policymakers and governments of the EEC members, afraid of losing sovereignty, did not welcome favorably the measures proposed in the Memorandum, challenging them from many perspectives. More generally, as opposed to the Commission, they tended to interpret the provisions included in the Treaty of Rome rather narrowly. On the other hand, all the Governors of the central banks asked their legal services whether the Council and the Commission had the right to interfere with the central banks' established regulations and directives and could eventually impose binding decisions (La Politique Monétaire dans le cadre du Marché Commun 1962). When their legal services confirmed this, the governors reacted, favoring further integration in monetary issues (Maes 2006).

However, the Council agreed to give some credit to the Commission, especially on the economic side, deciding for the creation of several committees, such as the Committee of Governors of the Central Banks, the Budgetary Policy Committee, and the Medium-Term 
Economic Policy Committee. Also, other domestic actors such as the Governors of central banks favored the deepening of monetary cooperation, suggesting that a Council of Central Bank Governors should be created and that supranational monetary issues should be discussed first at the domestic level (Maes 2006). Conversely, concessions on monetary issues were more limited but the establishment of the Committee of Governors by Commission proposal in 1964 to handle a temporary balance of payment crisis in France and Italy, confirmed that the Council recognized the Commission as an actor legally empowered to take action in monetary issues. Additionally, the Memorandum reiterated the necessity to enact a provision already included in the Treaty of Rome but yet largely ignored -- the practice of consultation to discuss monetary problems among the EEC members, which the Council agreed to extend further to international monetary issues.

Among the ECC institutions, the Commission was not alone in pushing for further integration, since Tsoukalis (1977) emphasized the role of the European Parliament (EP) and the Monetary Committee in the development of monetary integration. For Tsoukalis, any initiative proposed by the Commission to bring about some progress in monetary cooperation was supported by the EP, inherently because in those days it was mainly composed by proEuropeans. That had to do with two facts. Firstly, the so called "permissive consensus" (Inglehart (1971), the generalized belief by the public at the early stages of European integration that the EEC was a good thing was reflected in the composition of the EP. Secondly, since the EP was an unelected powerless European arena representing the EEC but harmless for domestic governments, by definition it was filled by enthusiasts that received training to work in European issues and could establish an epistemic community at the EEC level (Kreppel 2002).

Other than these ideological reasons, in 1959 the Van Campen report released by the Economic And Financial Commission of the EP called for an institutional development for the 
management of monetary policy similar to the Federal Reserve System in the United States, following the assumption that a larger currency area would have paid dividends and generate gains for its participants (Louis 1990). Another initiative, deemed "bold and naïve at the same time" by Ungerer (1997: 88), was the proposal drafted in 1966 by the EP (the so called "Dichgans report") for a quick harmonization of short-term economic, fiscal and budgetary policies of the six members in order to render the maneuvering of monetary policy irrelevant and any sort of exchange rate fluctuation useless. Even if unrealistic, this proposal moved in the same direction of that already seen in the Commission Action Program, since both were mainly focused on moving sovereignty from the EEC members to the EEC institutions. Of course the power of the EP was very limited, but at least it was able to act on the debate over monetary issues and basically broke new ground towards "revolutionary" ideas that would be implemented later. The Monetary Committee pushed for a step forward, the centralization of monetary decisions and stricter coordination of economic policies. A report of the Monetary Committee issued in the early 1960s, almost replicating the one released from the economic and financial Commission of the EP, not surprisingly was adopted unanimously by the EP, even if this voting constituted only non-mandatory advice to initiate any bill. The commission itself would be inspired by such a report in defining its Action Programme for the Second Stage of the EEC (Tsoukalis 1977).

On a theoretical level, the emerging balance between European and domestic institutions, as outlined above, constituted a reasonable compromise between supranationalists and intergovernmentalists (Rosamond 2000). Theoretically, supranationalists were mainly represented by federalists and neofunctionalists, who expressed their enthusiasm about promoting further integration beyond domestic boundaries. On the other hand, 
intergovernmentalists considered the ECC as an intergovernmental organization to coordinate several restricted policies with minimal pooling of sovereignty, and were hostile to any further advancement towards a supranational system.

This conflict also reverberated in politics, since federalist scholars and politicians were pushing for a federated Europe with as much as possible evolution of powers towards the communitarian institutions. Dyson (1994) noted that support for European integration came from a new generation of politicians who had directly experienced the horrors of two world wars fought on European soil. With the sole exception of Paul-Henry Spaak, Belgian prime minister (1948-51) and foreign minister (1948-51, 1954-7, and 1961-6), they were Christian Democrats, such as Konrad Adenauer (German Chancellor 1949-63), Robert Schuman (French Prime Minister 1947-8 and Foreign Minister 1948-52), and Alcide De Gasperi (Italian Prime Minister 1945-53). As noted by Dyson "federalist politicians were far from able to use their will indiscriminately $[\ldots]$ but they represented a new climate of ideas that was to prove a potent new factor" (Dyson 1994: 59).

As I have already mentioned in chapter 3, the most prominent federalist movements after World War II produced very important documents such as the Resolution of the Congress of Europe in 1948 (also known as the Hague Congress) which was a short political program calling for the creation of "an economic and political union in order to assure security and social progress" (Congress of Europe 1948) ${ }^{6}$. Some of these federalist supporters, such as Jacques Monnet and Robert Schuman, theorized an incremental and steady transfer of sovereignty

\footnotetext{
6 The "Hague Congress" was organized by the International Committee of the Movements for European Unity, which brought together representatives of several pro-European organizations (European Union of Federalists, United Europe Movement, Nouvelles Équipes Internationales, European League for Economic Cooperation). Around 800 delegates attended, including politicians and statesmen, trade union leaders, businessmen and intellectuals. Among them, Harold Macmillan, Konrad Adenauer, François Mitterrand, Richard von CoudenhoveKalergi, Alexandre Marc, Altiero Spinelli, Bertrand Russell, Jacques Monnet, and Robert Schuman. President of the Congress was Winston Churchill.
} 
towards the EEC, while another school of thought, led by Spinelli, argued for a "big bang" solution with immediate and all-embracing empowerment of communitarian institutions (Spinelli and Rossi 1944). Monnet was a very proactive supporter of a federated approach to the extent that in 1955 he resigned as President of the High Authority of ECSC after France had refused to ratify the European Defence Community (EDC), thus certifying the impossibility of having any kind of integration in defence, at least in the short term. After the failure of EDC, in 1955, Monnet founded the Action Committee for the United States of Europe in order to revive the federalist approach as a rationale for European integration. Also, the "Ventotene Manifesto for a Free and United Europe", written by Altiero Spinelli and Ernesto Rossi, was a theoretical pamphlet discussing the economic and political unification of Europe from a federalist perspective and by a federal constitution (Spinelli and Rossi 1944).

Similarly, neo-functionalists such as Ernst Bernard Haas (1958) and Leon Lindberg (1963) envisioned a functional spillover across policies, following the logic according to which integration in one policy necessarily leads to integration in a neighbouring policy. From that perspective, a monetary union would be the logical and functional complement of a customs union (ultimately becoming an economic union) to minimize the risks of increased trade among countries. The distinction between neofunctionalism and federalism is somewhat subtle, since Haas (1971) suggested that neofunctionalism can be seen as the mechanism towards the attainment of federalism-in-action, while federalism has a more normative underpinning, focusing on the outcome of integration.

On the other hand, even though intergovernmentalists - both academics and politicians the French President Charles De Gaulle - generally agreed about the need to promote integration across boundaries to secure peace and economic reconstruction in Europe, they conceived the 
EEC as an intergovernmental organization firmly controlled by electorally legitimated domestic governments. Furthermore, they believed that integration should occur only in narrow policy areas. In that way, they claimed that any decision affecting the European Communities had to be achieved by consensus of all the six governments to avoid the forced enforcement of any unwanted decision on dissenting members. For intergovernmentalists, the integration was supposed to be driven by members' interests and, as such, by members' sovereignty, which could be only pooled instead of being fully transferred to the European Commission. As a consequence, they emphasized the important role of the Council of Ministers as the expression of domestic governments (Moravcsik 1998).

In political terms, both sides were able to succeed. On the one hand, the European Commission, vested with regulatory powers, represented the ECC interests, and the progressive extension of QMV granted more power to the Commission. The European Parliament, as well, represented a voice always pushing for more integration, even though its real power to influence the communitarian decision making process was very limited. Ungerer (1997) noted that the very first comprehensive report dealing with the coordination of monetary policy was released in 1962 from the Parliament's Committee for Economic and Monetary Affairs. The Van Campen report explicitly called for the creation of a common monetary institution modelled after the federal reserve system of the United States and Germany (Louis 1990). The parliament adopted the report in a resolution calling for "the step-by-step establishment of a federal organization of EC central banks in a central institution for the conduct of common monetary policy" (Ungerer 1997: 86). On the other hand, the creation of the Council of Ministers, mainly deciding by consensus, highlighted the driving role of member states in integration. The failure of the EDC mainly due to De Gaulle's reluctance to give up French sovereignty in a sensitive area like defence policy 
and De Gaulle's boycotting the Council (the so called "empty chair crisis") represents a perfect example of intergovernmentalism in action, resistant to accept forms of integration deemed as too extreme. A further victory for intergovernmentalists was represented by the institutionalization of a de facto national veto power in the "Luxembourg Compromise" (1966) stating that if a domestic interest was at stake, a unanimous vote had to be pursued even if QMV would have been formally enough, which empowered domestic governments vis-à-vis the Council of Ministers.

Other problems highlighted by Pinder (1998) and Tietmeyer (1999) were that France and Germany did not really engage in any serious discussion towards the opportunity of proposing a single currency. France signing the ECC Treaty already conceded the opening of its traditionally protected market while the German economy was regulated according to the concept of the social market economy, and in foreign policy Germany was swinging between Europeanism and Atlanticism (van Ypersele and Kœune 1985: 35). Additionally, Tsoulakis (1977) argued that France saw the need of creating an eventual fixed exchange rate among European currencies, discussed in the mid-1960s as functional to the emerging Common Agricultural Policy (CAP), while Germany believed that economic coordination was a pre-condition preceding any progress in the monetary field. Simultaneously, Italy and the Netherlands had limited interests in pushing for a monetary union or CAP, since the main target of Italy was the development of a regional policy granting development funds for its underdeveloped southern regions, and the Netherlands showed interest mostly in incomes policy (Tsoukalis 1977). Italy and the Netherlands also feared a monetary integration dominated by the Franco-German axis that began to emerge in the 1960s. Furthermore, two failed applications in the 1960s by the UK to enjoy the EEC caused Italy and the Netherlands to draw back from any proposal for further integration. Even though these two 
applications were unsuccessful, they delayed any progress in monetary integration, since the UK was seen by the Italian and Dutch governments as a potential destabilizing member given its traditional euro-skeptic stance and repulsion towards cooperation in monetary affairs (Tsoukalis 1977). As noted by Ungerer (1997), in fact, the UK favored a flexible exchange rate regime to be able to tackle speculative attacks against the sterling, which was aimed at decreasing its reserve role in the monetary system.

Furthermore, different visions of monetary policy clearly emerged at the domestic level. Two dealt with the inherent conception of monetary policy. One debate focused on whether or not economic integration should precede monetary integration. On the one hand, Germany, the Netherlands, Italy and later the UK, after its entrance into the EEC, supported the strategy of seeking coordination and compatibility in economic areas such as fiscal and wage policies and later culminating this high degree of convergence with a common monetary policy and a common currency. On the other hand, France, Belgium, Luxembourg and the EEC Commission argued that integration in monetarist affairs (i.e. the creation of a stable exchange regime and mutual credit lines) will inevitably lead to economic convergence (Ungerer 1997). Inevitably, these apparently contradictory views cross-fertilized each other and often a policy solution constituted a compromise between the two strategies (Ungerer 1997; Verdun 2010). The other conflicting vision was on the way monetary policy ought to be conducted. On one hand, in Germany, the Netherlands and in Belgium the management of monetary policy was considered a prerogative of the central bank and as such independent from political pressures, while in France, Italy and soon-to-be member the UK, governments had the power to influence monetary policy (Ungerer 1997). 
Other differentiations involved mid-range issues. According to Tsoukalis (1977), the method of economic planning followed by the Commission setting up programs and stages to reach an economic target reflected the French tradition of managing its economics through national plans. Conversely, this method was opposed by Germany, which, in the name of competition and free market, was suspicious of this particular form of state intervention in the economy and of the harmfulness of medium-term economic forecasts, preferring a progressive convergence among members as the method to reach integration (Maes 2004). As a matter of fact, as observed by Ungerer (1997), after WWII Germany underwent a liberalization of its economy beyond the requirements of EEC Treaties. Another area of disagreement was the plan of the French president De Gaulle to attack the predominance of the "hegemonic" US dollar by converting French reserves of US dollars into gold, as opposed to the German attitude to consider the Atlantic monetary cooperation strategically important. As a matter of fact, despite these sometimes apparently irreconcilable differences on the scope and breadth of the European integration emphasized by the intergovernmentalist school, the pooling of national sovereignties among six independent European countries in key industrial sectors such as coal and steel can be seen as an astounding outcome made possible from political compromises occurring among governments, under the supervision of supranational institutions.

Other major obstacles to the success of the ECC during the 1950s and 1960s came from the external environment. In this regard, I already discussed the Bretton Woods agreements regulating the international monetary regime. Another problem was the presence of competing or overlapping economic integration projects promoted by other European countries sometimes not participating in the EC as yet. The Benelux Customs Union between Belgium, the Netherlands, and Luxemburg was established in 1948, much earlier than the EEC, and became an economic 
union in 1960. Furthermore, in 1957 the European Free Trade Association (EFTA) originated from the competitive reaction of the UK to the creation of the EEC. In 1960 with EFTA the UK brought together several countries (Austria, Denmark, Norway, Portugal, Sweden, and Switzerland) with the aim of establishing a progressive elimination of customs duties among members. Finally, the Organization for European Economic Cooperation (OEEC) was created to oversee the disbursement of the Marshall Plan for the reconstruction of Europe after World War II and continued as a research and advisory agency. More broadly, as I will clarify later, the presence of major obstacles threatening the survivability of the economic (and later monetary) integration project at any given time was a recurring feature until recently.

In front of a promising economic integration, the feasibility of any common currency was restricted to wishful thinking of several visionary pioneers. The two main federalist documents introduced above (the Resolution of The Hague Congress and the Ventotene Manifesto), written in the aftermath of World War II, did not explicitly call for monetary unification. It was after the Treaty of Rome that federalists took action to outline a European monetary system. Dissatisfied with the limited leverage of the EPU and the vague provisions of the treaty towards monetary issues, the former first president of the ECSC High Authority and fervent federalist Jean Monnet lobbied for a united Europe and asked the architect of the EPU Robert Triffin and the economist Pierre Uri to develop an outline for a European monetary system. Triffin's proposal for the first stage of the EEC (1957-1961) ambitiously (but unsuccessfully at that time) envisaged a single European currency and a European monetary authority (Maes 2006).

At first sight, the first discussions on the development of a possible common currency involving the EC member states were a mere esoteric theoretical exercise, for various reasons: disagreements concerning the nature of the EEC and even more skepticism towards 
the opportunity to promote monetary integration, the continuing payment surpluses of the EEC members in the early 1960s which cooled down any urgency towards the achievement of a pan-European monetary project (see Cooper 1968: 81-94), and the Bretton Woods agreements which regulated the international monetary system since from 1945 . However, Tsoukalis (1977) and Ungerer (1997) identify two factors which in neo-functional terms were expected to support further monetary integration. The first was the creation in 1965 of the system of common agricultural prices within the CAP, which was supposed to function properly eventually with a correlated regime of fixed exchange rates among the EEC members' currencies. The other factor mentioned by Ungerer (1997) is that all the six member states in the 1960s had a stable and progressive economic development, the so called "economic boom", which gave them a common platform upon which to build a panEuropean economic project. These two factors paralleled the Bretton Woods agreements explicitly supporting the doctrine of a stable exchange regime in the international monetary system and the need to create solid bases for a customs union and ultimately a common market with stable exchange rates (Ungerer 1997). As a result, the debate between the first option (internal flexibility of the EEC monetary system along with the external rigidity), and the second one (internal rigidity and external flexibility), moved towards the latter option (Johnson 1973; Ungerer 1997), in line with Article 107 of the Treaty of Rome, which had already discouraged competitive devaluations via flexible exchange rates regime. Competitive devaluations were a monetary tool providing sure benefits for the country enacting it, while at the same time causing havoc in the international economy, not to mention in a customs union or a soon-to-be common market such as the EEC. As a matter of fact, the move towards a permanently stable intra-EEC exchange regime not only constituted 
a precursor of a common currency, but was also considered in EEC circles as a sort of "de facto" monetary union (Cooper 1972).

\subsection{The Steps towards an Economic Union and a Single Currency (1969 to 1999)}

While the plan discussed in the early 1960s were "quickly lost in the mists of time" (Barnes and Barnes 1995: 123), denoting a period that Tsoukalis (1997:12) has acutely defined as the "prehistory of EMU", the very first political moves on a possible common currency involving the EEC member states are contained in several crucial macroeconomic policy documents of the period under consideration: the Barre Report, the Werner Report, the European Monetary System, the Single European Act, the Delors Report and the Maastricht Treaty.

As a general premise, a survey of the international monetary system at the start of the 1970s is unavoidable. Since the end of WWII and during the 1960s the United States suffered a protracted balance of payments deficit resulting from the aid granted to the recovery of the European economies after the massive destruction occurred during WWII, the rise of military expenditures with the wars in Korea and Vietnam, and the outflow of private capital. The persistence of this deficit over time (Ungerer 1997), the assessment that the US was deemed as unwilling to take action to stabilize the international system (Tsoukalis 1977), and the circulation of huge amounts of US dollars in the monetary international system (Barnes and Barnes 1995), tended to erode trust in the US dollar as a stable currency able to work as an anchor in the Bretton Woods system. As a consequence, in the late 1960s the US dollar was not perceived as a stabilizing currency holding the international system together, and producing generalized scepticism towards the sustainability of the Bretton Woods agreements. As observed by 
McNamara (2003), the Bretton Woods framework was perceived as unstable, especially by France. As well, Barnes and Barnes (1995) noted that the UK, soon to be member, was supporting the decline of the Bretton Woods system of fixed exchange, since it suffered massive speculative attacks on sterling, caused by the progressive liberalization of capital movements.

As a consequence, there were discussions concerning a reform of the system (Tsoukalis 1977; Ungerer 1997). Virtually any existing economic organization - such as the IMF, the Group of Ten (G-10) composed by the biggest economies in the world, the EEC, and domestic governments - was taking part of this discussion. The debate focused on the overall framework of the system and how the two traditional sources of liquidity, the US dollar and gold, could be complemented or replaced (Ungerer 1997). Other issues under discussion were how to tackle the emergence of imbalances of payments through the creation of an international adjustment process and how exchange rates should relate among currencies.

Several solutions were proposed but abandoned, such as the return to the gold standard and the creation of a new international reserve currency denominated Composite Reserve Unit (CRU). The exit strategy from Bretton Woods aimed to avoid shocks as occurred after the collapse of the Gold Standard. The strategy was drafted by the G-10 in the so called Smithsonian Agreement which was supposed to be a temporary regime allowing an adjustable peg system targeted to achieve currency realignment. As a matter of fact, it was reluctantly replaced with a regime of floating exchange rates (Tsoukalis 1977). By the mid-1970s, all the major currencies were floating, meaning that exchange rates ceased to be the prime tool used by government to enact monetary policy.

Within the EEC framework, the risks of uncoordinated domestic economic policies in the 1960s, rising tension in an emerging common market featuring internal turbulences (such as 
those occurred in Italy and France), and instability in the international monetary system showed that the improvement of cooperation in economic and monetary issues became a necessity (Ungerer 1997). These threats were increased by the fact that in 1968, after the end of the scheduled transition period, the EEC became a customs union. The need to strengthen coordination in such environment became an important raison d'être to work on further integration in both economic and monetary affairs. All these external and internal tensions brought about a further "politicization of monetary issues" (Tsoukalis 1977: 63). As such, it is only by the 1970s that European political leaders began seriously to discuss the feasibility of a single currency.

In terms of domestic politics, Tsoukalis (1977) observes that the election of George Pompidou in 1969 reversed the position of France, traditionally hostile to any form of supranationalism under de Gaulle, who retired to private life. De facto, this opened options for negotiations that were impossible during the Gaullist era. In such environment the rise of the Franco-German axis, backed by Belgium and Luxembourg on monetary issues, constituted an important engine to propel further integration (see Loedel 1995; Hendrix and Morgan 2001: 5787), even if it ignited the fear in Italy and the Netherlands of a possible Franco-German domination (Tsoukalis 1977).

As always, following the conventional institutional procedure of the EEC, in 1968 the Commission took the initiative, moved by the desire to build a European response to the crisis of the international monetary system, and by the awareness that little progress had been made towards economic and monetary integration, despite repeated formal and solemn commitments to further advancement. Raymond Barre succeeded Marjolin in 1967 as the Commissioner for Economic and Financial Affairs, and in that capacity in February 1968, forwarded to the Council 
the first Barre Report (sometimes referred as the "Barre Plan"). According to Maes (2004), the Barre Report was showing the sublimation of the Commission activism, but inherently was recommending the same measures already proposed in the past that failed to trigger any action. The "Memorandum on Community Action in the Monetary Sphere" was a confidential and short monetarist manifesto generically reiterating old commitments already set out in the 1962 Commission's Action Programme for the Second Stage of the EEC, such as (i) prior consultation and mutual consent before any adjustment of exchange rates, (ii) a collective stance in the international monetary system and institutions, (iii) the introduction of a system of mutual assistance, and (iv) the establishment of an European unit of account (Maes 2004). Innovatively, the Barre Report mentioned for the first time the concept of a "European monetary identity" in order to tackle the cultural notion of the currency as a national symbol but, to please French positions, it did not mention the opportunity to set up new supranational institutions to this end (de Lattre 1999). The Barre Report was criticized by Germany and the Netherlands, opposed to any advancement towards monetary union without a sustainable economic convergence, at that time limited to the customs union and the CAP. Thus, the report reignited the debate between economic and monetarist approaches (Szász 1999:11).

The Commission and Barre needed to pay attention to these observations and, in February 1969, they forwarded to the Council and to the Committee of the Governors a more prudent but thicker "Barre Memorandum" properly balancing economic and monetary measures in order to seek a satisfying compromise between the two parts (Commission of the EEC 1969). According to Maes (2004) the 1969 memorandum was even more modest that the 1962 Action Programme. In this regard, it highlighted the interdependence already achieved in economic terms, but emphasized the need to progress further to go beyond the "mere juxtaposition of 
independent national policies" (Ungerer 1997: 89). In addition, to find a midway between supranationalists and intergovernmentalists, Tsoukalis (1977) noted that the Commission cautiously decided to shift from the previous "utopian" stance unrealistically pushing for quick progress towards the achievement of monetary union to a more pragmatic and realistic strategy. Language as well was more cautious, shifting from the emphasis on "integration" to the adoption of terms such as "coordination" and "cooperation". Finally, in the preamble of the memorandum, the Commission decided to emphasize that the ECC was "an original and complex entity, consisting of both national and Community elements" (Commission of the EEC 1969: 5). In real terms, the memorandum called for (i) convergence of medium-term economic policy, (ii) coordination of short term economic policy, and (iii) a community mechanism for monetary cooperation, composed of short term monetary support and medium-term financial assistance, while the proposal to establish a European unit of account contained in the first Barre Report was abandoned.

The Committee of the Governors that received the Barre Memorandum believed that further economic and political integration was needed to progress towards a monetary union, even if individual opinions were slightly differentiated. For the governor of the National Bank of Belgium, Baron Ansiaux, "monetary cooperation can be justified more on political than on economic grounds" (quoted in Maes 2004:21). Conversely, other governors believed that the coordination of economic policies was the most important issue.

After the Barre Report had been forwarded to the Council, European leaders met at the Hague Summit of December 1969 to put together a plan to create a European Monetary Union. These talks were concurrent to the first discussions on enlargement involving the United Kingdom, Ireland, Denmark, and Norway which, with the exception of the latter, ultimately 
joined the EEC in 1973. Especially the prospective of the UK joining the EC represented a contentious point, with Italy and the Netherlands supporting its entrance to avoid a FrancoGerman domination in European affairs, while France, Belgium and Luxembourg were more reluctant, favouring a policy of deepening before progressing on enlargement (Tsoukalis 1977).

The prime minister of Luxembourg, Pierre Werner, in 1970 was appointed as the leader of a study group which finalized its findings in the so called Werner Report. There is consensus that the Werner report was the turning point of monetary integration in Europe (Tsoukalis 1977; Kruse 1980; Moravskic 1998). As such, many historical narratives covering EMU start with the Warner Report (Kenen 1995; Coffey 2000; Mulhearn and Vane 2008) dismissing the earlier evolution I depicted above. But earlier events were important, since they planted the seeds on which further evolution could grow.

The final and ambitious goal of the Werner Plan would be the irreversible convertibility of EC currencies, the permanent locking of exchange rates and, possibly, a single currency. To achieve this, the report called for a closer coordination of economic policy, with interest rates and management of reserves decided at the EEC level as well as coordination of domestic budgetary policies. Not surprisingly, the Werner Report represented a source of inspiration for later evolution of EMU, both in terms of strategy and contents.

The results of the Werner Plan were published in a joint document ascribed to both the Council and the Commission, openly reflecting the fact that it represented a compromise between the two institutions. As always the Commission had to reach a breakthrough between monetarists (France) and economists (Germany), using the strategy of "parallelism" (Kruse 1980) in which progress in intensifying the coordination of economic policy parallels a greater cooperation in monetary issues at the Community level. 
The Werner Plan expressed the EEC members' political will to establish in 1980 an economic and monetary union in which "goods and services, people and capital will circulate freely" (Council and Commission 1980: 9). The Plan was set out in three stages. The first stage, supposed to last three years, was aimed at narrowing fluctuations among EEC currencies, creating a fund to provide credit for troubled countries, and improving the coordination of economic policies in the light of EEC guidelines. The second stage forecast the putting into practice of fixed exchange rates and the setting up of "a centre of decision for economic policy and a Community system for the central banks which could be based on organisms of the type of the Federal Reserve System in the United States" (Council and Commission 1970:13), which today can be seen as a forerunner of the European Central Bank. The third step of the Werner Plan did not contain detailed provisions, but obviously was represented by the attainment of a common currency.

While the idea of a federalization of monetary affairs was accepted by Germany, the recommendation was too strong for the French government that wanted to emphasize the balance of power between supranational and domestic powers in order to confirm its support for a cohesive and effective EEC (Kruse 1980). In any case, as clearly stated in the Werner Report, all members had to accept the idea that a redistribution of sovereignty would be inevitable, should they want to engage in an economic and monetary union, since it "demands the creation or the transformation of a certain number of Community organs to which powers until then exercised by the national authorities will have to be transferred [...]. Economic and monetary union thus appears as a leaven for the development of political union, which in the long run it cannot do without", (Council and Commission 1970:12). 
The first stage of the Werner Plan took place in a very dramatic environment represented by the collapse of the Bretton Woods agreements in 1971 and the rise of oil prices in 1972. At that time, the EEC was still seeking to follow the doctrine of exchange rate stability but at the same time leaving some flexibility for EEC members to decide their own policies (Ungerer 1997). Urged by the first stage of the Werner Plan to reduce the magnitude of intra-currency fluctuations, in 1972 EEC members set up their own exchange rate mechanism using a technical solution called the "Snake in the Tunnel" (see Kruse 1980:111174; Kölliker 2006:153-162).

As shown in figure 1, the Smithsonian agreement set narrow bands of fluctuation $( \pm 2.25 \%)$ for currencies to move relative to their central rate against the US dollar. This provided a tunnel in which European currencies could trade. The Snake worked as an area of monetary stability until 1973, when the US dollar had been set free to float as a response of a major crisis following the collapse of Bretton Woods and the oil crisis. As a result, only Germany, the Benelux countries and Denmark were able to keep their currencies within the narrow bands while on various occasions from 1972 to 1974 the UK, Italy, and France had to withdraw from the Snake (and eventually return) because of speculative attacks causing uncontrolled fluctuations of their currencies. Despite these serious shortfalls, and the fact that the Snake became a sort of "de facto Deutsche mark zone" (Van Oudenaren 2005: 201), according to Verdun (2010) the Snake worked moderately well in the 1970s, even if it was clear that an advancement in monetary cooperation by reducing fluctuations was inevitably incompatible with domestic autonomy in economic policymaking (Kruse 1980). As well, mere consultation or limited coordination on economic issues proved to be detrimental for 
the interests of the EEC members and for the survivability of the communitarian project (Tsoukalis 1977).

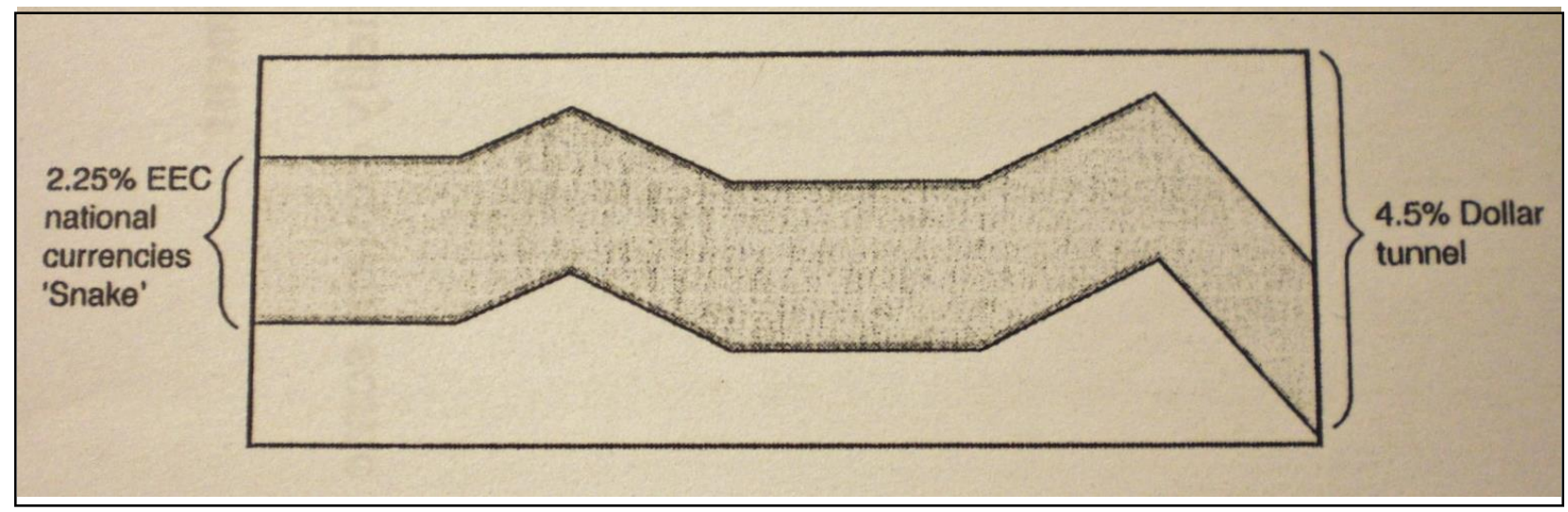

Fig. 1 - The "Snake in the Tunnel" (adapted from Coffey 2001).

On the monetary side, in 1973 a provision that had been already suggested in the Werner Plan and in the Barre Report was established by a proposal of the Commission. The European Monetary Co-operation Fund (EMCF), which replaced the European Payments Union, consisted of a pool of financial resources available for all members having financial difficulties (Kruse 1980; Mulhearn and Vane 2008). Such a mechanism, able to mobilize collective financial resources in case of need, was aimed at facilitating the alignment of exchange rates and improving the operation of the Snake and coordination among central banks. It ultimately targeted the irrevocable locking needed to create a monetary union. Other targets were to simplify the method of debt settlements and to improve the EEC credit mechanism (Tsoukalis 1977). Italy was the first country to ask for monetary support in 1974, followed by Ireland in 1976. The political authority in charge of the EMCF was the Committee of Governors of Central Banks, which was required to work in agreement with the Council, by a proposal of the Commission. Again, during the negotiations, Tsoukalis (1977) reported that several countries 
opposed the pooling of reserves, notably Germany and the Netherlands, fearing a distorted usage of funds not to facilitate economic convergence - as they were supposed to - but to finance deficits. On the other side, Italy wanted an EMCF granted with maximum powers, favoring an EEC responsible for open interventions in the exchange market and an extension of the credit system. France supported the creation of the EMCF to improve the monetary authority of the EEC. Finally a compromise was reached, with the creation of the EMCF with limited powers.

From an economic standpoint, Mulhearn and Vane (2008) noted that during the first stage members a showed uneven level of commitment to harmonizing their macroeconomics, and tended to aggravate the situation by using uncoordinated forms of monetary policies. This happened because the coordination of economic policies was based on the institutional setting already in place in the 1960s, without further innovation (Tsoukalis 1977). As such, despite a formal and full implementation of the EEC guidelines and procedures, it must be said that the existing provisions targeting the coordination of economic policies were extremely vague. For example, the required Community medium-terms programmes represented a mere exercise of putting together national forecasts. This loose framework allowed governments to formally commit themselves to EEC rules without feeling bound by any decision taken by the Council. As a result, Tsoukalis (1977) assumed that from 1969 to 1973 monetary unification via positive integration represented a central issue in the political debate, while on the economic side not much was improved after the achievement of the customs union through negative integration in the form of elimination of tariff barriers at the end of the 1960s.

After the realization of the first stage that - according to most scholars -, yielded modest results, in a few years the Werner Plan fell into disarray, and the attempts to enhance economic and monetary integration lost momentum. There are various and concurrent reasons behind the 
failure of the plan, depending more on the widespread emergency created by international turmoil than on EEC members' ideological opposition to further integration. The most important motivation, as evidenced by Tsoulakis (1977), is that the Werner Plan was designed in 1970 on the basis of the Bretton Woods system, which collapsed shortly thereafter, undermining the premises on which it had been founded. Furthermore, the oil crisis produced divergent responses among EEC members. In fact, pressing economic problems such as high inflation, the rise of unemployment rates, a shortage of oil supply, balance of payments deficits, and stagnant economies after years of economic boom, inevitably elicited fast and uncoordinated responses by EEC members detrimental to long-term strategies, as required by the Werner Plan. In this case, ideology had little to no importance in the resurgence of domestic politics, mainly led by economic emergency. In such a situation, it was clear that targeting a monetary union in 1980 was not a feasible goal.

The mid-1970s were pervaded by the attempts to recover from the state of disarray and crisis. Not surprisingly, Germany, France and the Netherlands opposed any advancement (Tsoukalis 1977). Given this scenario, the Commission only could try to preserve what it had already been achieved, working to reintegrate the various currencies within the Snake boundaries and suggesting a further narrowing of exchange margins. To this end, in 1975 a report by Leo Tindemans (prime minister of Belgium) backed by the Commission to the European Council, proposed the institutionalization of the existence of two groups of members in the EEC: those participating in the Snake and those outside it. This proposal, which now would be considered as resurgence of intergovernmentalism through differentiated integration, was never implemented.

What is surprising, however, is that despite Germany's recurrent complaints on the lack of progress in economic integration, and protracted evidence that governments had no intention 
to give up the control of economic policy for the sake of stabilizing exchange rates, the second half of the 1970s saw the re-launch of integration, initiated with monetary issues under the aegis of the so called "new monetarism" (Tsoukalis 1977:165; Mulhearn and Vane 2008:162). In 1975 the Commission proposed the creation of a parallel currency, named Europa, emphasizing that it would have been primarily used as a reserve currency, and possibly as a private asset (Tsoukalis 1977). The obvious reverberation of this proposal was the transfer of power from the domestic to the supranational level, and the possible creation of common institutions as a recipient of this power. Because of the potential speculative risks associated with such idea and the reluctance of governments to lose sovereignty over monetary and fiscal policies, the plan did not succeed.

The "paradoxical" attempt to preserve sovereignty, put into practice by governments opposing further integration, collided with two facts. The first was the increased economic interdependence among the economies of the EEC members. Secondly, they had to prove being able to avoid widespread instability when challenged by external shocks and avert what occurred at the beginning of the decade. From this perspective, as noted by von Hagen (2013), a second integrationist trend culminated in 1979 with the launch of the European Monetary System (EMS) and its centerpiece, the Exchange Rate Mechanism (ERM), as an arrangement to stabilize European currencies and European economies after the collapse of Bretton Woods in 1971.

The revival of monetary integration came from the leaders of France and Germany (Ludlow 1982; Moravscik 1998) backed by the European Commission President, Roy Jenkins, and by an agreement between the central bankers of the EEC members (Ungerer 1997:148; Padoa Schioppa 2000). For different reasons, Chancellor Helmut Schmidt and President Valéry Giscard D'Estaing agreed on pursuing a closer monetary cooperation leading to a "zone of monetary stability" in Europe (European Council 1978) by establishing the EMS, supposed to 
replace the Snake (Moravcsik 1998). Roy Jenkins, diverging from the conventional Community method, in a series of speeches given in 1977 put forward a plan developed by Schmidt and Giscard D'Estaing to overcome currency instability.

According to Moravcsik (1998: 298), this was the "first overt act of German political leadership in the history of European integration", even though he ultimately assesses any progress in integration as a result of interstate bargaining, reflecting the power and interests of large EEC/EU members, rather than the "desires of supranational entrepreneurs" (Moravscik 1998:313). It is true that the Council of Ministers was intended as a "directorate" from larger countries such as the UK, France and Germany, but smaller countries (within which Moravscik disputably includes Italy) preferred a supranational management lead by the Commission. Obviously, on this point a compromise was needed. As a matter of fact, the supranational fervor included further integration at the EEC level, the first direct election in 1979 of the European Parliament, and the extended use of Qualified Majority Vote in the European Council. This fervor was compensated by the creation of the European Council, a top level intergovernmental summit featuring the meeting of chief executives, formalized in the period between 1974 and 1988. The European Council allowed domestic chief executives to get deeply involved in all the major decisions affecting European affairs.

On this fact, there are two opposing interpretations. Moravscik (1998) saw the extension of QMV as an increase of the power of intergovernmentalism since countries leading EMU (i.e. Germany and France) could get what they wanted without the requirement of unanimity. It would be enough for them to build a coalition large enough to meet QMV requirements. On the other side, a more traditional interpretation understands the extension of QMV as a victory for supranationalism, since proposals for further integration do not require unanimity anymore and 
stalemate in the decision-making such as the Empty Chair Crisis is not going to occur anymore. Based on De Gaulle's opposition to extend QMV in the 1960s, the latter interpretation seems more appropriate.

Another matter of contention is on the inherent nature of the EMS. On the one side, Moravscik (1998) and Szász (1999) observe that the Bundesbank insisted on providing changes in the setting up of EMS, often against the political positions of the German government. As such, they concluded that the EMS is a reverberation of Bundesbank preferences. On the other side, for other authors such as Gros and Thygesen (1992) and Fratianni and von Hagen (1992), the EMS was deliberately designed as a framework assessing rules to achieve policy coordination among EEC members, and not as a system centered on the Deutsche mark.

The EMS included the European Exchange Rate Mechanism (ERM), a system designed to reduce exchange rate variability and achieve monetary stability in Europe against the turbulence of the global currency market (European Council 1978). In effect, EMS was a system of controlling EEC member's currency realignments, since each had a fixed rate against an artificial currency named European Currency Unit (ECU), whose value was set every five years by a weighted basket of members' currencies. Governments had to assure that these rates fluctuated not more than the narrow band of 2.25 percent, while Italy was granted an exceptional band of 6 percent. In addition, France, Italy and Belgium were able to expand the financing of balance of payments already set in the Snake. The United Kingdom negotiated to enter the EMS in 1990 upon inevitable concessions, showing that EMS was not just a German enterprise serving German interests. For Gros and Thygesen (1999) the EMS could be considered as a geographically expanded version of the Snake, while for Padoa Schioppa (2000) it resembled a kind of local Bretton Woods scheme. For Szász (1999:62), “there are striking similarities 
between events of 1969, leading to the adoption of EMU as a common objective, and those in 1978, leading to the establishment of EMS". All three positions confirm the plausibility of using issues of timing and sorting out in the progress towards integration, modeled after what has been already put into practice in previous experiments.

According to Van Oudenaren (2005) and Padoa Schioppa (2000), EMS worked reasonably well over the 1980s, because it saved free trade inside the EEC during hard times, it pointed to macroeconomic convergence among EEC members, and it prevented the EEC from being heavily affected by the ups and downs of the US dollar. Other significant improvements are noted by Padoa Schioppa (2000). Firstly, currency realignments were decided by collective decision. Secondly, realignments were accompanied by change at the various domestic levels aimed to bring national economies closer among themselves. Similarly, Ungerer (1979) noted that EEC members agreed to set up common policy targets to drive domestic policy actions, which represented a considerable step forward if compared to the vague provisions included in the Treaty of Rome. One example mentioned by Van Oudenaren (2005) is France under President Mitterrand, who tried to keep its currency closely aligned with the German Mark and reversed French protectionism in place since 1968 in favor of economic liberalization, renouncing to enact a socialist agenda that would have paid electoral dividends. Thirdly, Padoa Schioppa (2000) observed ECU growth in private markets as a means of doing business, showing that economic agents legitimized its potential as a possible currency of the EEC. Fourth, EEC members realized that it was better to establish a parallel regional currency in which they had some decisional power, rather than pegging their currencies to the dollar or the yen. This parallelism in which the domestic level and supranational dimension coexisted was a successful compromise allowing progress in monetary integration without replacing domestic currencies. 
Most of these improvements were finally enforced by governments after decades of formal support but de facto inertia towards fulfilling ECC obligations. After being ravaged by major international shocks over the 1970s, they realized the importance of concomitant policy obligations, ultimately enacting macroeconomic convergence and monetary stabilization, as repeatedly suggested by the Commission over two decades. In this case, the issues of timing and sequencing and experimenting appeared to be particularly relevant. For example, the EMS worked as a precursor of the introduction of the Euro, since from 1999 the EU members' currencies were "irrevocably fixed" against each other and against the euro (Padoa Schioppa 2000). Furthermore, as noted by Ungerer (1979) the emphasis on the need to seek convergence of economic policies framed by the EMS and its realization by members in the 1980s would constitute the rationale for the Delors Report of 1989 and the Maastricht Treaty of 1992.

The early 1980s saw the initial phase of EMS in action, featuring trial and orientation (Ungerer 1997). The second phase of the development of EMS took place from 1983 to 1987, which consolidated earlier results due to the extension of its mechanism to improve the attractiveness of ECU (the so-called Palermo package in 1985) followed by the pursuit of stability-oriented policies, increased macroeconomic convergence, and little realignment of central rates. From this standpoint, Ungerer (1997) noted that the participation in EMS exerted a disciplinary effect on EEC members and enhanced the credibility of policy "imposed" by the EEC. In such environment, capital liberalization and economic convergence were on the rise again in early 1980s, after a decade of progress in monetary integration but stagnation in regard to economic integration (see Kruse 1980:174-200). Incentivized by the real attempts made by EEC members to pursue a higher degree of macroeconomic convergence and by German and Dutch pressures for progress in economic integration, in 1985 the President of the Commission, 
Jacques Delors, proposed a white paper on completing the internal market by the end of 1992 (Commission 1985). The Council convened an intergovernmental meeting that worked out the Single European Act (SEA), adopted in 1986 and ratified by all members in 1987, intended as a legal amendment of the Treaty of Rome, and significantly expanding the domains of economic integration. The Single Act codified a number of major economic preconditions for fair competition and long-term stability within the internal market. The most visible one was the complete liberalization of people, goods, services and capital movements, with the removal of physical, technical and fiscal barriers. This made it easier for the harmonization by the mutual recognition of domestic norms and regulations. From an institutional perspective, it expanded the use of QMV and gave the European Parliament a role in the legislative process. On monetary issues, it introduced a new article (Article 102a) into the EEC Treaty concerning EMU and cooperation among member states in this field, with special reference to the EMS and the development of the European Currency Unit, which were incorporated in the Treaty and thus legitimized as acquis communataire. The SEA also mentioned that monetary union should be a reachable goal of the European Community. Despite the fact that SEA did not plan how and when this could be achieved (Hix 2005). The SEA represented the awareness of the need to progress towards an economic and monetary union. This occurred despite the resistance and the skepticism of the majority of the members (Louis 1990).

The third phase of EMS, simultaneous to the ratification of SEA, lasted from 1987 to 1990 and featured a Basle/Nyborg agreement by the Governors Committee (1987) that further strengthened the EMS, by improving the power of surveillance of domestic monetary inconsistencies. As a result, significant steps were made in achieving low inflation and stabilization of exchange rates of EEC members' currencies. However, Louis (1990) noted that 
after ten years of the establishment of EMS, the supposed institutional setting was not enacted yet. Further, countries with weak currencies such as Italy feared the problem of asymmetry, since they believed that the burden of keeping the EMS efficient was on them. Another problem raised by the EEC committees was whether a single market required the realization of a common currency (Ungerer 1997).

Finally the Single Market was achieved in 1992. From an international perspective it can be seen as a direct response to the rising competitiveness of the Japanese economy and the Asian Tigers (Hong Kong, Singapore, South Korea, and Taiwan) in the 1980s. After a decade of progress in monetary integration in the 1970s, then, in the early 1980s the competition of Asian economies worked as a stimulus to revitalize economic integration in the EEC. As such the SEA in 1986 set the timeline for the realization of a single market, a core objective since the Treaty of Rome (1957) but achieved only in 1992 (Dinan 2007). According to Ohmae (1990, 1995) a single economy in Western Europe was functional to build one of the three key economic macroregions in a globalizing economy (the other two being Japan and the US). As a result, trade between Japan and Western Europe dramatically consolidated with advantages for both parties. In 1980 Western Europe exported to Japan only 7.4 percent of its total export, a digit that rose to 16 percent in 1988 and 18 percent in 1990. Japan exported to Western European economies 16.6 percent of its total export in 1980, 21 percent in 1988, and 22 percent in 1990. Japanese Foreign Direct Investments in the EEC rose from 11 percent in 1980 to 21 percent in 1989 (Dobson et. al. 2001).

A number of studies (Moravscik 1998; Gros and Thygesen 1998; Dyson and Featherstone 1999; Szász 1999; Kolliker 2006) examined the negotiations that occurred during the end of the 1980s featuring supportive, reluctant, and ambiguous members' positions on the opportunity of 
achieving a single currency. Specifically, the domestic political reactions and subsequent bargaining in the European debate shows that the setting of a common monetary policy was not an easy task. According to Kölliker (2006), at the end of the 1980s there were three countries strongly supportive of monetary integration: France, Italy and Belgium. For France, a common currency represented a way to bypass the domination of the Bundesbank and the Deutsche Mark in monetary affairs. Basically, the establishment of a European currency was the "price" Germany had to pay for its reunification.

France could also count on the support of other members such as Italy, who were not particularly enthusiastic about the idea of a "Bundesbank-cloned" monetary regime. In conclusion, the pressure from France and other members was able to dilute the predominance of Germany in monetary policy-making. For Jones (2002), the EMU provided a change in the Franco-German relationship, notwithstanding difficult negotiations during and after the EMU implementation. According to Van Oudenaren (2005), the Maastricht treaty reflects French preferences about timing and German preferences about the conditions. France also took advantage of the German call to collaborate toward a monetary union, because otherwise, for German Chancellor Helmut Kohl an EMU without France would not make sense (Dyson 2002). According to Dyson (2002), another reason explaining France's resistance to opposing Germany's predominance is that in the EMU, the "goodness to fit" worked well in France too. In this sense, Howarth (2002) noted that French governments tended to interpret the EMU as an extension of French state activity at the EU level together with the defense of its domestic monetary interests. Italy had to deal with the possibility to postpone its entrance into the EMU, due to lack of prerequisites. However, especially in the case of Italy, the Euro was intended as an "external tie" and to work as a tool to promote 
some urgent domestic reforms, allowing Italy to respect the timing scheduled (Dyson and Featherstone 1996, 1999).

Conversely, Germany, the Netherlands, Luxembourg, Spain, Greece, Portugal and Ireland expressed considerable reservations, while the United Kingdom and Denmark were openly hostile to monetary unification ${ }^{7}$. Austria, Finland and Sweden, not members yet and as such not taking part of the negotiations, had strong reservations too. As noted by Kölliker (2006), differences coming from the smaller economies such as the Netherlands, Luxembourg, and Ireland were smothered using compensation such as side payments, package deals, or issue linkage. In addition, several of the technical reservations coming from reluctant members were included in the final draft of the treaty. For example, Germany obtained the new European Central Bank (ECB) being institutionally designed to be independent from political interference (winning over French resistance that preferred a politically controlled management of monetary policy), and having price stability as its main task. Furthermore, the headquarters of the ECB was decided to be in Frankfurt, and Germansponsored Wim Duisenberg would be its first president. Last but not least, Germany wanted the implementation of a stability pact to be respected by all members, in line with its traditional approach focused on economic integration. However, Kölliker notes that Greece, Portugal, Austria and Finland did not receive satisfactory compensation but still decided to enjoy EMU. Furthermore, since Austria and Finland entered the EU in 1995, they had to accept EMU in full, as it had been decided before their entrance. Greece represented an ambivalent case. After an initial decision to opt out from the EMU, Greece decided to adopt

\footnotetext{
${ }^{7}$ Greece joined the EEC in 1981 and the EMS in 1998, Spain and Portugal joined the EEC in 1986, but Spain accessed the EMS in 1989 and Portugal in 1992.
} 
the Euro. As a result, in 1999 the Greek currency took part of ERM II, and Greece has been part of the Eurozone since 2001.

The reluctant UK government contested the political desirability of the EMU, followed by Denmark. As a result, a derogation status has been granted for the countries that wanted to opt out from the EMU, following the principle according to which participation in the EMU cannot be imposed on any member of the time. At the same time, Szász (1999) noted that British obstructionism towards monetary integration could not veto any progress. Sweden, a member since 1995, has also deliberately chosen to stay out of the mechanism, thus maintaining its currency. Sweden is expected to participate in ERM II in order to meet the convergence criteria required to adopt the Euro (Swedish Parliament 2009), but its exceptional status has been tolerated by EU institutions.

A new debate among European policymakers toward the opportunity of monetary integration started in 1988. This debate, ignited by the president of the Commission Jacques Delors, showed how policies could be affected, if not initiated, by political leaders who strongly followed their political beliefs and personal expertise (Dyson and Featherstone 1999). In this regard, for Szász (1999), Delors represented a major force in the integration process. Additionally, Dyson and Featherstone (1999) highlighted the importance of successful political entrepreneurship and institutions at the supranational level, downplaying the role of domestic interests and challenging the idea that Germany was able to upload its model to the EU. Similarly, according to Verdun (1998) the features of the technical committees - such as the Monetary Committee and the Committee of Central Bank Governors - involved in the EMU creation match the definition of "epistemic community" proposed by Haas (1992: 3) as follows: 
"An epistemic community is a network of professionals from a variety of disciplines and backgrounds, they have (1) a shared set of normative and principled beliefs, which provide a value-based rationale for the social action of community members; (2) shared causal beliefs, which are derived from their analysis of practices leading or contributing to a central set of problems in their domain and which then serve as the basis for elucidating the multiple linkages between possible policy actions and desired outcomes; (3) shared notions of validity -- that is, intersubjective, internally defined criteria for weighing and validating knowledge in the domain of their expertise; and (4) a common policy enterprise -- that is, a set of common practices".

As such, the role of the Delors Committee in propelling EMU was essential. Finally, David Cameron (1995) has examined the role of monetary experts, concluding that the process leading to EMU should be seen as both supranational and intergovernmental. For Szász (1999) Delors had the merit of understanding the importance of a unanimous report agreed by all parties in order to create political momentum for EMU, and he successfully negotiated to make it happen. Only Moravscik (1998:341) tended to dismiss the role of Delors, which was derogated to "that of a secretariat". Accordingly, the committees were instructed by member states, which in protecting their interests acted regardless of what the Delors Report recommended.

After the major domestic differences were resolved, in June 1988 the European Council confirmed the objective of the progressive realization of EMU. It mandated a committee chaired by Delors to study and propose concrete stages leading to this union. Not surprisingly, Delors was appointed as a chair of the technical Committee for the Study of 
Economic and Monetary Union, whose report, usually referred to the "Delors Report", constituted the core of the Maastricht Treaty.

For von Hagen (2013) and Kühnhardt (2009) the targeting of a monetary union in the 1990s was a direct consequence of the end of the Cold War that caused fears in Europe about a too powerful Germany after its unification in 1990. Additionally, another problem was whether post-unification Germany would stay committed to European integration or turn its attention on domestic issues, i.e. rebuilding Germany as a country, a nation and an economy. It is true that the German government under Chancellor Helmut Kohl during the 1990s remained committed to European integration (Szabo 1992; Zelikow and Rice 1995), but in early 1990s these tensions were resolved with the project of sharing a currency complementing the single market.

Once the monetary union became a real target, Dyson (1994) noted that three options were on the table concerning how to achieve it and how to set the transition period. The first option, not really taken into account seriously, was proposed by the UK in order to avoid a single currency. This model forecasted an open competition among currencies, meaning that members had little incentive to enact deviant policies but conversely had political incentive to converge their monetary policies, thus creating a de facto monetary union. The second option, proposed by France, was the enforcement of a parallel currency, possibly the already existing ECU, circulating alongside domestic currencies. In such way, domestic currencies had to compete with the parallel currency. The third option, presumably devised by technocrats, was the most ambitious one, envisioning the evolution of EMS into a single currency. Needless to say, the third option ultimately prevailed. 
As already stated by the Werner Report, the Delors Report reaffirmed three unavoidable conditions for a monetary union: (i) the total convertibility of currencies, (ii) the complete capitalization of capital flows and integration of financial markets, and (iii) irrevocable locking of exchange rates. The plan of achieving a Single Market by 1992 fulfilled the first two conditions, but the third one was debated. The Delors Report clearly stated that any further advancement in getting EMU was made possible by the EMS, "that has served as a focal point for improved monetary policy coordination and has provided the basis for multilateral surveillance within the Community" (Committee for the Study of Economic and Monetary Union 1989:8). The Delors Report also praised the progresses recently made with the SEA, even if "an economic and monetary union implies far more than the single market programme" (Committee for the Study of Economic and Monetary Union 1989:12). From these observations, it is evident that EMU represented an incremental step after the Werner Report, the EMS and SEA.

The Delors Report stated the principle of parallelism between economic and monetary union, "being two integrated parts of a single whole". On the one side, economic union, taken together with the Free Trade Area, the Customs Union, and the Single Market, the economic union would be the last of the four stages delineating the overall EU economic integration. To the single market, the economic union would add common competition, structural and regional policies, and macroeconomic policy coordination, including binding rules for budgetary policies and oversight on fiscal policies (Committee for the Study of Economic and Monetary Union 1989:16). On the other side, the monetary union would be constituted by (i) the adoption of a single currency (the euro), (ii) a single monetary authority - the European Central bank (ECB) -, (iii) and a single monetary policy across the euroarea 
(Verdun 2010: 325-326). In this regard, the most prominent and visible policy target of the Delors Committee was to create a common currency.

The most evident institutional development of the Delors Committee was to create a common currency and the ECB at the heart of the European System of Central Banks (ESCB). Concerning institutional development, with the Report recommended that "the responsibility for the single monetary policy would have to be vested in a new institution, in which centralized and collective decisions would be taken" (Committee for the Study of Economic and Monetary Union 1989:21). As for the ESCB in charge of the monetary policymaking of the Community, the Report suggested that it "should be organized in a federal form" (Committee for the Study of Economic and Monetary Union 1989:21). Furthermore, the Exchange Rate Mechanism II (ERM II) replaced the ERM in 1999. The function of ERM II is to avoid excessive exchange rate fluctuations or misalignments between the euro and other EU currencies. After a central rate between the euro and the country's currency is established, the domestic currency is then allowed to fluctuate \pm 15 percent above or below this central rate ${ }^{8}$. The General Council of the ECB is in charge of monitoring the proper functioning of ERM II that mainly serves two purposes. The first one is to avoid the disruption of economic stability within the single market. Secondly, to assist non-Euroarea countries prepare themselves to join the euro. In fact, a country has to participate in ERM II without severe tensions for at least two years to become a candidate for the adoption of the euro (European Commission 2013b).

\footnotetext{
${ }^{8}$ The Estonian Kroon, Lithuanian Litas, and Slovenian Tolar were included in the ERM II in 2004; the Cypriot pound, the Latvian lats and the Maltese lira on 2005; the Slovak koruna on 2005; the Bulgarian lev in 2007; Romania plans to join ERM II in 2014.
} 
The economic, monetary and institutional targets were intended to be achieved adopting an incremental strategy based on a three-stage approach, as the Werner Plan did in the past. The plan represented a blueprint for further work on EMU, and was approved in the 1989 by the European Council held in Madrid. The Council decided that the first stage was to initiate in 1990 within the existing institutional framework, featuring complete freedom for capital transactions, increased cooperation between central banks, free use of the ECU, mandatory participation in ERM for all EEC currencies, and improvement of economic convergence. In this respect, the first step was aimed at facilitating the goal of the single market, as already stated in SEA. It is particular interesting to note that the Committee of the Governors of the Central Banks in 1990 wrote a draft for the ESCB and the ECB, which, with few changes, would become the statute later in the decade.

In 1993, a third amendment of the Treaty or Rome took place, following several intergovernmental conferences and reports from the Committees of Central Bank Governors and the Monetary Committee. The Treaty on the European Union (TEU), also known as the Maastricht Treaty, established the European Union (EU), together with the second stage of the EMU (Ungerer 1997; Van Oudenaren 2005). What was known as the EEC was renamed the European Community (EC) and became one of the three EU pillars ${ }^{9}$. Technically, Maastricht provided some convergence criteria (also known as the "Maastricht criteria") for EU member states to enter the third stage of the EMU and adopt the Euro ${ }^{10}$. Four underlying

\footnotetext{
9 The other two pillars were the Common Foreign and Security Policy (CFSP) and the Justice and Home affairs (JHA).

${ }^{10}$ The four main criteria are based on Article 121(1) of the European Community Treaty. The purpose of setting the criteria is to maintain the price stability within the EU even with the inclusion of new member states. The member who wants to adopt the euro need to meet certain criteria which include inflation rate (no more than 1.5 percentage points higher than the 3 best-performing member states of the EU); government finance (the ratio of the annual government deficit to gross domestic product (GDP) must not exceed 3\% at the end of the preceding fiscal year); government debt (the ratio of gross government debt to GDP must not exceed $60 \%$ at the end of the
} 
principles drive the EMU. First, subsidiary defines the balance of power in the union, according to the Treaty on European Union (1992, Art. G.5). Second is the principle of parallelism between economic union and monetary union, which can be seen on the whole as a principle emphasizing the "economic convergence" process as already declared by the Treaty Establishing the European Community (TEC) in $1957^{11}$. Third, the principle of cohesion was aimed at reducing developmental inequalities between richer and poorer regions within member states ${ }^{12}$. Finally, the principle of irreversible progressivity, that is, the three scheduled steps, emanates from the first stage of the EMU that started in 1990, with the full liberalization of capital movements among members.

The second stage began in 1994 and was characterized by the creation of the European Monetary Institute (EMI) as the institution in charge of the technical preparations for EMU. The EMI was directed by a president decided by the Council and by the governors of the central banks. As such, the EMI took over the tasks of the Committee of Central Bank Governors and replaced the EMCF. The EMI functioned as a consultative body formulating non-binding opinions and recommendations to governments and the Council of Ministers (Ungerer 1997). Furthermore, members were urged to further align their monetary and fiscal policies (Van Oudenaren 2005).

In 1995 the German government proposed a "Stability and Growth Pact" (SGP) which was deemed as controversial at that time by the French government that wanted to keep a monetarist design of EMU (Hix and Høyland 2011). The intent of the stability pact

preceding fiscal year; exchange rate (applicant countries should have joined the exchange-rate mechanism (ERM II) under the European Monetary System (EMS) for 2 consecutive years; long-term interest rates (the nominal long-term interest rate must not be more than 2 percentage points higher than the 3 best-performing member states.

${ }^{11}$ Title II (arts $\left.102-109\right)$, Part Three of the EEC.

${ }^{12}$ Art 130A TEC, para. 2. 
was to fill a loophole in the Maastricht treaty, which defined the macroeconomic convergence criteria to access EMU but did not specify the discipline that would apply, after entrance into the eurozone (Pond 1999). The rationale behind the SGP was that the surveillance and the harmonization of budgetary policies would have prevented the outbreak of financial instability from any member of the Eurozone, precluding the contagion to the Euroarea. Furthermore, this pact was aimed at avoiding members manipulating statistics or promoting austerity just to enter into the club and then lapse back. In order to assure that the integration process would be irreversible, Germany contended that violators should be forced to pay fines. In 1997 the SGP was approved, with some inevitable changes after the negotiations: fines for budget deficits over three percent would not be automatic but subject to decisions by the Council of Ministers, and the debt criterion was loosened (Savage 2005). As a result, the Eurozone members had to comply with their deficit and debt requirements of 3 and 60 per cent of GDP. This pact, together with the convergence criteria, became one of the major economic components of EMU. The basis of the SGP were to be found in the assumption that it would be difficult to manage monetary policy at the supranational level while at the same time domestic governments had discretion on fiscal policy.

The last stage was initiated in 1999 and consisted of the creation of the European Central Bank (ECB) and the replacement of ERM by ERM II, in which currencies were allowed to float within a range of $\pm 15 \%$ with respect to a central rate against the Euro. With the third step, members decided to set an irrevocable fixing of conversion rates, in order to delegate irrevocably their monetary policy to the ECB. The euro was introduced in the financial markets, and the Stability and Growth Pact entered into force. The Commission and the EMI reported to the Council about the progress of members in fulfilling their obligations 
to meet the convergence criteria and hence their eligibility to take part of the eurosystem. The ECB and the ESCB were established and their leading figures were appointed.

\subsection{Monetary Unification in Practice from 1999}

The third step initiated with the real game changer - the EMU in action for the financial markets since 1999 and the real circulation of the euro coins and bills since 2002. This section focuses on the narration of the first decade in which EMU was operating. From a legal perspective, treaties regulating EMU have been rarely written from scratch, but have been almost always modified or amended following a cumulative logic, which represents another aspect of gradual federalization. The original EMU polity, policy and politics laid down in the Maastricht Treaty (1992) remained relatively untouched by the Treaty of Amsterdam (1999), the Treaty of Nice (2003). Ultimately, since 2010 the rules governing EMU have been encapsulated in the Title VIII of the Treaty on the Functioning of the European Union (TFEU) also known as the Lisbon Treaty, which amended the Maastricht Treaty and the Treaty establishing the European Community (TEC), both ratified in 1992. The recent initiatives aimed at strengthening the economic side of EMU as a response to the economic downturn will be elucidated in the following section.

From the inception of the euro up to the Lisbon Treaty, the EMU framework was regulated through the "Community Method" delineated by the Maastricht Treaty (1992), as opposed to the "Intergovernmental Method" adopted for the Common Foreign and Security Policy (CFSP) and the Justice and Home affairs (JHA). The Community Method applied to policies where the EU had an exclusive competence, and balanced powers of EU institutions 
with those of domestic governments and the European Council. The Commission had monopoly of legislative initiation, since Maastricht decisions in the Council were taken by QMV, the European Parliament played an important legislative role, and the Court of Justice was entitled of providing a uniform interpretation of EU law. In contrast, in the intergovernmental method, domestic institutions predominate over supranational institutions in policies where members still hold a great deal of sovereignty resulting in loose cooperation at the supranational level. The right of initiative was shared between the Commission and the EU members, the Council decided unanimously, the European Parliament had a mere advisory role, and the Court of Justice power was very limited (European Union 2011).

A second institutional aspect is represented by the balance of power between EU and members' institutions with specific reference to policymaking. In this regard, EMU was regulated by the "Cooperation Method", which was characterized by the European Council setting policy targets and macro-directions, the Commission monopoly of the right of initiative, generalized use of qualified majority voting in the European Council, an active role for the European Parliament, and an interpretation of EU law by the Court of Justice (Cini and Pérez-Solórzano Borragán 2010).

The "Cooperation Procedure" (Article 252 of the TEU) is visualized in figure 2 European Union $(2010)^{13}$. Agenda setting was the first step of the legislative process. It involved the Council (setting macro directions and targets) and the Commission, who had exclusive right to initiate legislation. The first reading involved the participation of the European Parliament (EP) that could propose amendments. If this was the case, the Commission could incorporate or reject these amendments. Finally, the Council, acting by a Qualified Majority Voting (QMV) adopted a common position $(\mathrm{CP})$ confirming or amending the proposal from the Commission. The second reading involved again the EP that was informed by the Council on the reasons leading to the CP. This

\footnotetext{
${ }^{13}$ The other two procedures were Consultation and the Co-decision. The Maastricht Treaty laid down which policies were subject to which procedure.
} 
communication also reported the EP why the Commission had rejected the EP amendments during the first reading. If, within three months of such communication, the European Parliament approved the $\mathrm{CP}$ or did not take action, the CP became EU law.

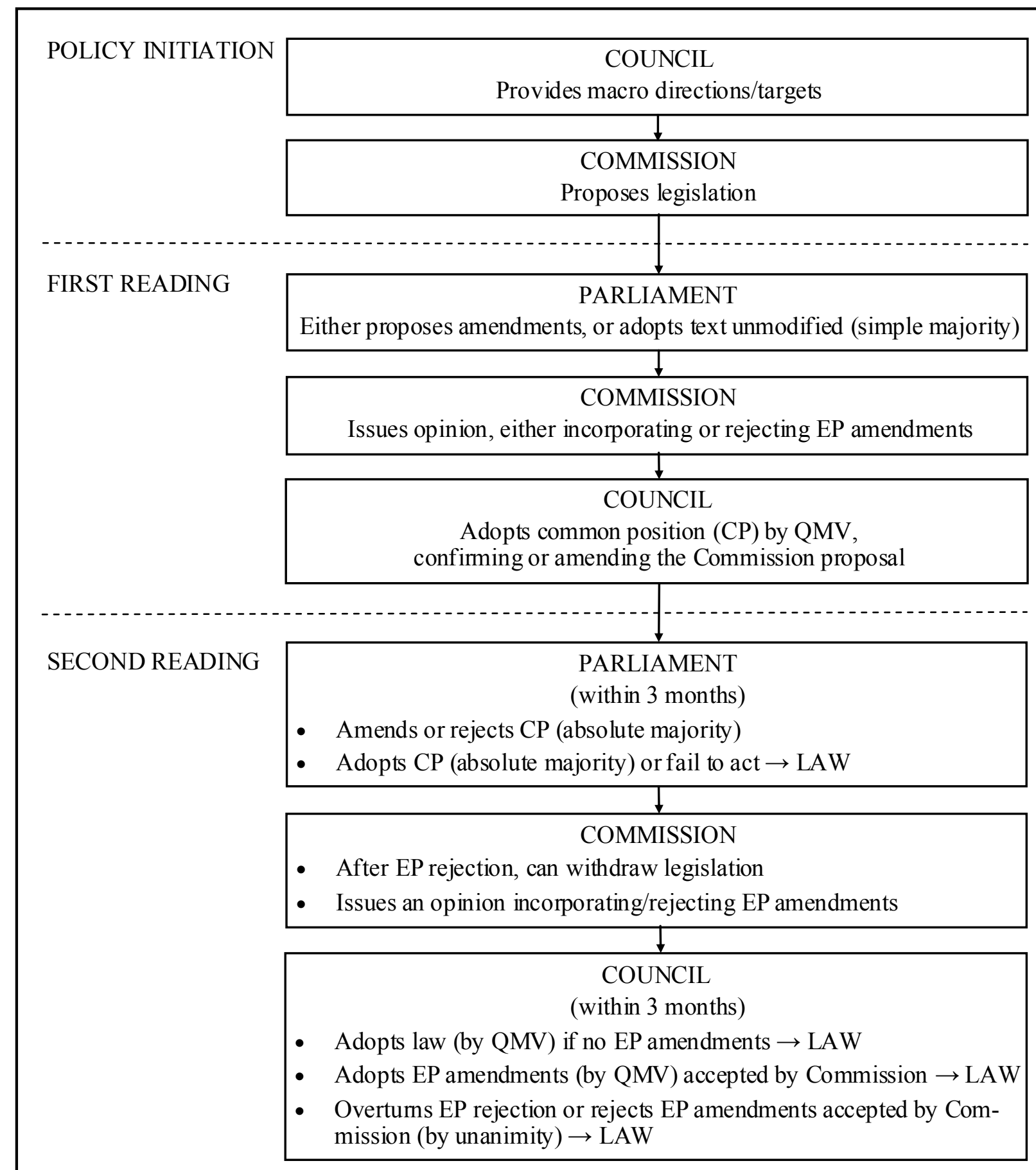

Fig. 2 - The "Cooperation Procedure" (adapted from Hix 2005). 
If the EP rejected the CP by absolute majority of its component members, the Commission could withdraw legislation or pass it to the Council that could overrule the EP by unanimity to get the $\mathrm{CP}$ transformed in EU law. If the EP amended the CP, the Commission could issue an opinion incorporating or rejecting the EP amendments that had to be approved by the Council by QMV in order to become EU law. This procedure empowered a supranational and an intergovernmental agency to set the agenda (respectively the Commission and the Council) and to approve legislation (respectively the European parliament and the Council).

Since 1992, after the Maastricht Treaty was signed, the Cooperation Procedure has been largely replaced in various policies by the "Co-decision procedure" that gives equal weight to the European Council and the European Parliament as co-legislators. The Lisbon Treaty in 2009 set forth the Co-decision Procedure as the "Ordinary Legislative Procedure" and extended it to almost any policy area in the EU. However, in EMU this procedure was only applied to several limited aspects ${ }^{14}$. The previous Cooperation Procedure in place in EMU has been repealed by the Lisbon treaty and mainly replaced by the "Consultation Procedure" that severely curbed the power of the EP in the EMU legislation. The main reason is the pressure of the French government since 2003 (Andenæs and Usher 2003) that intensified after French voters rejected the European Constitution in a referendum held in 2005. It is true that the Lisbon treaty salvaged all the major provisions already written in the proposed Constitution, but this was a significant change intensifying the democratic deficit and showing a resurgence of intergovernmentalism. In the Consultation Procedure, in fact, the power of the European Parliament is limited to mere consultation or information that can be ignored by the Commission and, ultimately, the Council

\footnotetext{
${ }^{14}$ The OLP applies under Article 121(6) TFEU on the procedural aspects of the multilateral surveillance procedure, Article 129(3) TFEU, for amending certain provisions of the European System of Central Banks (ESCB) and the European Central Bank (ECB) Statute, and Article 133 TFEU regarding the currency law (Meunier 2013).
} 
is the sole legislator. In setting the agenda there is still a balance between a supranational and intergovernmental institution, but ultimately only the Council has legislative powers.

The Lisbon Treaty also repealed the previous "three pillars system", replaced by a precise threefold classification concerning the division of competences between the EU and its members. EMU is one of the few policies on which EU institutions have "exclusive competence", the others being the customs union; the establishing of the competition rules necessary for the functioning of the internal market; the common commercial policy; and the conservation of marine biological resources under the common fisheries policy. With the only exclusion of the latter, all the others clearly have to do with economic issues. Exclusive competence means that “the EU alone is able to legislate and adopt binding acts in these fields. The Member States' role is therefore limited to applying these acts, unless the Union authorises them to adopt certain acts themselves" (Article 3 of the TFEU). Internal market is a policy where EU members can "share competences" with the EU "only in so far as the EU has not exercised, or has decided not to exercise, its own competence" (Article 4 of the TFEU) ${ }^{15}$. This second category comprises all the policies that were meant to be kept at an intergovernmental level, such as freedom, security, justice and judicial cooperation in criminal matters (formerly known as "Common Foreign and Security Policy"). Finally, none of the policies related to EMU are included in the "supporting competences" subset where "the EU can only intervene to support, coordinate or complement the action of Member States. Consequently, it has no legislative power in these fields and may not

\footnotetext{
${ }^{15}$ Shared competence applies also to social policy, for the aspects defined in this Treaty; economic, social and territorial cohesion; agriculture and fisheries, excluding the conservation of marine biological resources; environment; consumer protection; transport; trans-European networks; energy, area of freedom, security and justice; common safety concerns in public health matters.
} 
interfere in the exercise of these competences reserved for Member States" (Article 6 of the TFEU $)^{16}$.

The first ten years of EMU have seen a resurgence of intergovernmentalism in in the economic field with the relaxation of the SGP from 2002 to 2004 and the revival of domestic politics in the monetary field after the enlargement process that was not followed by the adoption of the euro from new members. Looking at the first aspect, the rationale behind the SGP was the surveillance and the harmonization of budgetary policies to prevent the outbreak of financial instability from any member of the Eurozone. However, from 2002 to 2004, the European Commission found that France, Germany, Greece and Portugal persistently violated the SGP. This critical situation was reported to the Council of Ministers that ultimately decided not to impose sanctions on France and Germany (Savage 2007). Portugal in 2002 and Greece in 2005 were fined, but sanctions were never put into practice after the European Court of Justice declared that decision unlawful. To add insult to injury, under the pressure of France and Germany, in 2005 the EU Council and the EcoFin relaxed the SGP rules. The criteria were maintained unaltered, but other parameters were introduced to "excuse" possible infringements (De Grauwe 2005) ${ }^{17}$. The negative effects of this reform were that the budgetary criteria lost any credibility, the goals of the Maastricht Treaty became elusive, and the Council ridiculed the European Commission, and Eurozone members could circumvent SGP requirements. Some scholars believed that the SGP was unnecessary while others believed that sound macroeconomic fundamentals are crucial for a monetary union (see Savage and Verdun 2007) but undoubtedly intergovernmentalism revived (Vila Maior 2007). The long term effect of this situation was the

\footnotetext{
${ }^{16}$ Supporting competences applies to protection and improvement of human health; industry; culture; tourism; education, vocational training, youth and sport; civil protection; and administrative cooperation.

${ }^{17}$ These parameters were the behavior of the cyclically adjusted budget; the level of debt; the duration of the slow growth period; and the possibility that the deficit is related to productivity-enhancing reforms (De Grauwe 2005).
} 
eruption of the so called "sovereign debt crisis" since 2009 that reversed the trend towards a straightening of the rules of the European economic governance (see next section).

From the monetary perspective, the real novelty was constituted by the enlargement process. In 2004, an important chapter was written with the entrance of ten New Member States (NMS) from Eastern Europe into the EU. In theory, the situation of NMS is different from the one of the old members. In fact, NMS have to accept all the provisions that come with the entrance into the European Union, which includes the mandatory adoption of the Euro. Legally, none of them have the possibility to opt-out, being obliged to join the Euro-group according to the convergence criteria ${ }^{18}$. However, negotiations between the domestic and EU levels characterize not only the early, but also the late evolution of the EMU, with the inclusion of these NMS. Specifically, they have found room for negotiation with the aim of delaying their entrance into the Eurozone. As a result, of the ten NMS, Slovenia adopted the Euro in 2007, Malta and Cyprus adopted it in 2008, Slovakia did in 2009, Estonia in 2011 and finally Latvia in 2014. The absence of big economies such as Poland, the Czech Republic and Hungary in the Euroclub is confirming that convergence is far from completely successful ${ }^{19}$. Even Romania and Bulgaria, new members as of 2007, are expected to convert to the Euro without a definite timetable ${ }^{20}$.

This skeptical attitude of NMS towards the opportunity to enter the monetary union (eventually after drastic reforms for some of them) depends on domestic factors. In such way, differences emerge between (i) the six NMS that have already adopted the euro, (ii) several economically laggard countries that cannot enter the Eurozone since they do not respect

\footnotetext{
${ }^{18}$ The EU institutions tolerated UK's, Denmark's legal and Sweden's de facto opt out from the Euro but the Commission has stated it would not be indulgent on any future members attempting the same route. Then, opting out became a procedure that the EU was obliged to ban for future new members.

${ }^{19}$ The three largest countries that joined the European Union in 2004 (Poland, the Czech Republic and Hungary) are expected to adopt the euro, but without a precise timetable.

${ }^{20}$ Bulgaria enjoyed ERM II membership in the beginning of 2007. Romania plans to join ERM II in 2014, while adoption of EMU is not scheduled at any time so far.
} 
membership criteria, and (iii) some others that are recalcitrant and unwilling to join the euro because they could enter but do not want to since they are "politically delaying" their entrance. In addition, the European Commission, when NMS entered the EU, suggested to some of them to delay their entrance into the Eurozone since they were not ready. This evidence gave the way to studies on "differentiated integration" (Dyson and Marcussen 2010). It means that despite an overarching framework targeting an "ever closer union", differentiation across and within policies implementation and among members' fulfillment of EU membership criteria is the norm.

After monetary unification has been achieved, it is important to give a closer look at the institutional setting of EMU and their functions at any level: supranational (especially the European Central Bank and the European Commission), domestic (governments, the General Council of the European Central Bank composed by the governors of the national central banks of members) and informal (the Eurogroup). The division of competence among these institutions is complicated, the balance of power between them in any given policy stage is diverse, and the function of each institution is blurred.

The European Central Bank is an independent agency or a technical body that has is provided of legal personality under the EC Treaty and has become an official EU institution since the Lisbon Treaty. The ECB mandate is to maintain price stability in the Eurozone, deemed to be unavoidable for market credibility and economic growth. As noted by Kaltenthaler (2006), the ECB structure, independence and objectives are almost a replica of the German Bundesbank, which was inspired, to a great extent, by the American Federal Reserve System of the United States. One possible explanation of the adoption of a "Bundesbank-cloned" system was to 
accommodate German requests to stick with their successful monetary model in exchange of giving up monetary sovereignty.

Supporting the economies of the EU members is a secondary objective for the ECB (Chang 2009), since the aid towards a troubled country could threaten the credibility and reputation of the ECB, especially at an earlier stage. This approach has changed since the inception of the financial crisis because the ECB has played a more political and pro-active role vis-à-vis external threats challenging the economies of several troubled countries, as I will delineate in the following section. The ECB is the sole institution in charge of delivering monetary policy independent of political pressures coming from domestic governments or EU institutions. Any reform involving the ECB system would involve unanimity by the Council and, as such, difficult to accomplish (Hix and Høyland 2011).

There are two main bodies working in the ECB: the Executive Board and the Governing Council. The structure of the ECB shows a balance of power between the Eurozone members represented by the Governing Council and the EU institutions, represented by the Board (Hosli 2005). The Executive Board of the ECB is comprised of six members including the ECB President. All of them are elected by unanimity by the European Council. The Board is in charge of implementing the monetary policy set by the Governing Council. The ECB Governing Council comprises the presidents of the central banks of the Eurozone members and the ECB Executive Board. Its function is to set the goals of monetary policy. The voting method is by simple majority, with each country representing a vote. Before the 2004 enlargement, each country had a member in the Governing Council, while a reform has created a rotation system among Eurozone members. 
Hix and Høyland (2011) mention an episode involving the Council and the Board of the ECB showing that the ECB does not necessarily serve the interests of the biggest economies. Between 2003 and 2005 the central bank governors of Germany and France asked for a monetary policy in line with their economic cycles that were growing less than those of smaller economies. However, the Governing Council backed by the Board decided to implement a monetary policy satisfying the needs of the smaller economies, thus leading France and Germany to break the SGP rules in 2002-2005 in order to deliver their domestic political economies.

The main supranational institution in EMU is the European Commission. It supervises members' compliance with the primary treaty articles (currently the Lisbon Treaty), the SGP (reformed in Treaty on Stability, Coordination and Governance since 2012), the European Stability Mechanism (ESM) since 2012, and proposes recommendations to the Council on decisions to be taken. The Commission evaluates the implementation of EMU provisions, issuing regulations that have binding legal force in every EU member or directives for specific countries, and manages the EU budget (Hix 2005). The Commission issues non-binding recommendations to the European Council and EcoFin. The Lisbon Treaty has increased the powers of the Commission, capable of issue warnings to members about inflation, deficits, budgets and lack of reforms (Chang 2009). Finally, in EMU the Commission has the exclusive right to introduce legislation.

As of 2011, the Commission is divided into twenty-one directorates-general (DGs); that directly relevant to EMU is the Economic and Financial Committee (EFC) that since the Maastricht Treaty succeeded the Monetary Committee and was provided with more powers. The EFC is composed of representatives of economics ministries, the Commission and representatives of the ECB. The EFC is set up: 
"to promote policy coordination among the Member States. It provides opinions at the request of the Council of the European Union or the European Commission. Its preparatory work for the Council includes assessments of the economic and financial situation, the coordination of economic and fiscal policies, contributions on financial market matters, exchange rate polices and relations with third countries and international institutions. This Committee also provides the framework for preparing and pursuing the dialogue between the Council and the European Central Bank" (European Union 2013).

The European Council is the main intergovernmental body of EMU. It is composed of the heads of governments of EU members, it includes the President of the European Commission and is chaired by the President of the European Council, a new position created by the Treaty of Lisbon. As said earlier, it defines the political guidelines of EMU to the Commission, in EMU acts as the sole legislator, decides to advance (or limit) integration in new EMU issues or policies, and elects the President of the ECB and the ECB Governing Board. In historical perspective the Council has been always proactive in seeking further integration instead of preventing it, as some might have expected. Since the 1990s, the Council has decided about the establishment of the Economic and Monetary Union, the European Central Bank, the European System of Central Banks (ESCB) comprising the ECB and all the central banks of the EU, the Stability and Growth Pact, the adoption of the euro from new member states, and the reform of the Maastricht Treaty. Except for the exclusion of the Parliament in the governing procedures of EMU occurred with the Lisbon Treaty, all the other measures brought about a further centralization of EMU policy and polity. This trend towards centralization has been protracted since the inception of the 2008 crisis, as I will show in the next section. 
The Economic and Financial Affairs Council (EcoFin) is the main decision-making body of EMU. It is one of the oldest configurations of the Council. With reference to EMU, it is an intergovernmental body composed of the ministers of economics and finance of the EU members, each representing his/her country, both inside and outside the Eurozone. The budget ministers attend when budgetary issues are under discussion. The minister of economics from the members that holds the six-month rotating EU Presidency in the Council of Ministers chairs the EcoFin. It meets regularly, once a month (Council of the European Union 2014). EcoFin also takes part of the European Council when matters under discussion are relevant to its jurisdiction, like for example the SGP (Chang 2009). EcoFin is in charge of:

\begin{abstract}
"economic policy coordination, economic surveillance, monitoring of Member States' budgetary policy and public finances, the euro (legal, practical and international aspects), financial markets and capital movements and economic relations with third countries" (Council of the European Union 2014).
\end{abstract}

The voting method is QMV, except for fiscal issues that are decided by unanimity. When the EcoFin Council works on issues related to the euro and the monetary aspects of EMU, the representatives of the non-Eurozone still participate but do not have the right to vote. The Eurogroup is an informal institution composed of the ministers of economics and finance of the Eurozone members, usually meeting the day before the EcoFin meeting. It must be noted that in the last 15 years the EcoFin and the Eurogroup have been overshadowed by the European Council. The reason is that the most important decisions about the future of EMU are taken at the European Council level. Furthermore, given the severity of the financial turmoil that hit the EU hard since 2008, even though the Eurogroup became a formal institution of the EU in the Lisbon Treaty, it lost its momentum since it does not have any power to take decisions (Begg 2008). 


\subsection{Tackling the EMU Crisis since 2008: Euro Survival under Threat}

The first part of this section is dedicated to the description of the economic problems that took place in Europe since 2010, especially identifying its causes and highlighting the most critical cases. The second part will focus on the analysis of the political responses delivered by the EU and its members to tackle the financial turmoil, which I believe are prototypically federalist.

In 2011, the European Central Bank made it very clear why the bank debt crisis was interrelated to a sovereign debt crisis that could (perhaps fatally) destabilize the Economic and Monetary Union (EMU): since EMU is by definition characterized by a high degree of macroeconomic and financial integration among its members, a crisis erupting in one of its members can easily expand to others and put at risk the survivability of the common currency and possibly the future of the EU project (European Central Bank 2011).

While the crisis that affected the European countries, causing widespread economic recession, was initiated in 2008 by the collapse of the real estate market in the United States, the basis of the GDP contractions occurring in several European economies since 2010 was to be found exclusively in the Old Continent (Krugman 2012). In this regard, Buonanno and Nugent (2013) correctly observed that the Eurozone crisis started with a bank debt crisis and a sovereign debt crisis. In Europe, the bank crisis initiated after the international recession was caused by the collapse of the real estate market and other markets, which left the banks with a huge amount of unpaid debts, deflated values of their assets, and massive capital flight. In order to safeguard troubled banks and the overall credibility of their domestic banking systems, several eurozone governments decided to take over the massive debt. The nature of the domestic problems was different, but all of them exercised considerable pressure on the single currency. Spain and 
Ireland suffered by the meltdown of the real estate market, while Greek banks suffered capital flight, over 30\% of their deposits (Evans-Pritchard 2012). In order to cope with the massive public debt generated by bailing out banks and to reduce their budget deficits relative to GDP, troubled Eurozone countries had to enact austerity programs, i.e. spending cuts and tax increases, or a combination of the two. These bail-outs, associated with pre-existing poor governance, excessive public debt, lax fiscal management, and low GDP growth, sparked controversy and generated doubts about the security of governments to honor the refinancing of their sovereign debt. This caused interest rates to rise on government bonds and alarming rumors of possible defaults. To make things worse, troubled banks were burdened with government bonds of countries suspected of possible default (Buonanno and Nugent 2013), generating a paradoxical and potentially lethal situation for banks, countries, and the Eurozone.

Concerning the contraction experienced since 2011, Krugman (2012) noted that "Europe has had several years of experience with harsh austerity programs, and $[\ldots]$ such programs depressed economies even deeper into depression”. As well, Quiggin (2010:26) made it clear that "austerity policies, and the zombie ideas that support them, are bound to fail. Cienski (2010) confirmed that in Eastern Europe new governments had to cut spending, tighten belts and promote austerity programs in order to fix less than impressive economic performances after years of best behavior during the decade preceding their entry into the European Union in 2004. According to commentators, politicians and technocrats (such as the socialist president of France, François Hollande and the President of the ECB, Mario Draghi), fiscal austerity without growth is not enough to drag European economies out of the crisis. The assumption is that policies such as a harsh fiscal tightening, associated with increases in value added tax, cuts in government expenditure, labor market reform, and pay cuts for public sector in the most severe 
cases have a recessive impact on the economy, with loss of purchasing power and a rise in unemployment (Pignal 2010). More dramatically, Krugman (2012) argued that the alternative to fiscal austerity for countries facing financial distress would be the exit of the euro (and the return to national currencies), as happened in the 1930s when troubled countries had to exit from the gold standard. Further, following the assumption that default could be "an early recourse than a last recourse" (Beattie 2010:2), the option of letting Greece face its fatal destiny was on the table but ultimately did not go through.

Concerning the features of the economic and financial crisis, it must be noted that the turmoil affecting European countries is rather unusual, with two recession bottoms occurring in a short period of time ${ }^{21}$. This trend is clearly detectable from the analysis of the trends of real GDP volume growth rate, presented as percentage change on previous year from 2008 to 2012 (see table 1). The left chart of table 1 shows similar patterns among the GDP of the 27 EU members ${ }^{22}$. The same patterns can be observed in the aggregated chart (right chart) comparing the European Union, the Eurozone, and the US. In all cases, a clear negative trend is detectable since 2007, with 14 EU members in recession, culminating with the absolute bottom in 2009 with all of the 27 EU members in recession. The most severe cases were the three Baltic countries suffering double-digit recessions (Eurostat 2012). In the US, the financial crisis ended between late-2008 and mid-2009 (National Commission on the Causes of the Financial and Economic Crisis in the United States 2010). Not surprisingly, 2010 was a year of recovery not only for the US but also for all European economies, with the notable exception of Greece. Eastern Europe recovered as well, driven by the German economic expansion (Cienski and Bryant 2010). The following year was a year of mixed trends, with several European countries experiencing another economic

\footnotetext{
${ }^{21}$ For Shiskin (1974), a recession is denoted by "two down consecutive quarters of GDP" (Shiskin 1974:22).

${ }^{22}$ Croatia is not included in the chart because became member of the EU in 2013.
} 
downturn and others more virtuous, keeping on with the recovery path started in $2009^{23}$. According to the Eurostat data, however, from 2011 to 2013 sixteen European countries decreased their GDP growth rate, which means that they experienced another recession in a short period of time.

Aggregated data show that the trend of the average European Union (EU-27) GDP follows an almost identical pattern of the Euro-area (EA-17). As well, the US GDP highlights some similarities with the European GDPs. Table 1 shows that 2013 is expected to be the year in which all the European economies will recover, but the "usual suspects" Portugal, Ireland, Italy, Greece, and Spain - traditionally called "PIIGS" and recently renamed "Eurozone periphery" (Gros and Alcidi 2011) - are those most troubled and therefore under close scrutiny. This is because other than experiencing a protracted slowdown in economic activity and business cycle contraction, they also perform particularly poorly in terms of other macroeconomic indicators such as high unemployment rate, account deficits in the balance of payments, low investment spending, drop in household income and business profits, big trade deficits, interest rate rises of government bonds, and an increase of bankruptcies ("Europe's Single Debt Zone” 2010). Since 2009, the recession (especially in Greece, Ireland, Portugal, and Italy) has been defined as the "sovereign-debt crisis", causing fears over potential defaults that could ultimately fatally hit the Eurozone by contagion. Sovereign-debt crisis means that several European economies joining the euro have suffered protracted financial crisis and subsequent liquidity shortage, which made it difficult to refinance their government debts without the support of third parties providing rescue funds (Haidar 2012). This problem is made more severe by the fact that these countries already

\footnotetext{
${ }^{23}$ The sixteen recovering countries are Belgium, Cyprus, Czech Republic, Denmark, Finland, Germany, Greece, Italy, Luxembourg, Malta, the Netherlands, Portugal, Sweden, Slovenia, Slovakia, and the United Kingdom.
} 
had a history of week public finances, fiscal laxity, and labor rigidities ("The euro crisis grounded" 2010).

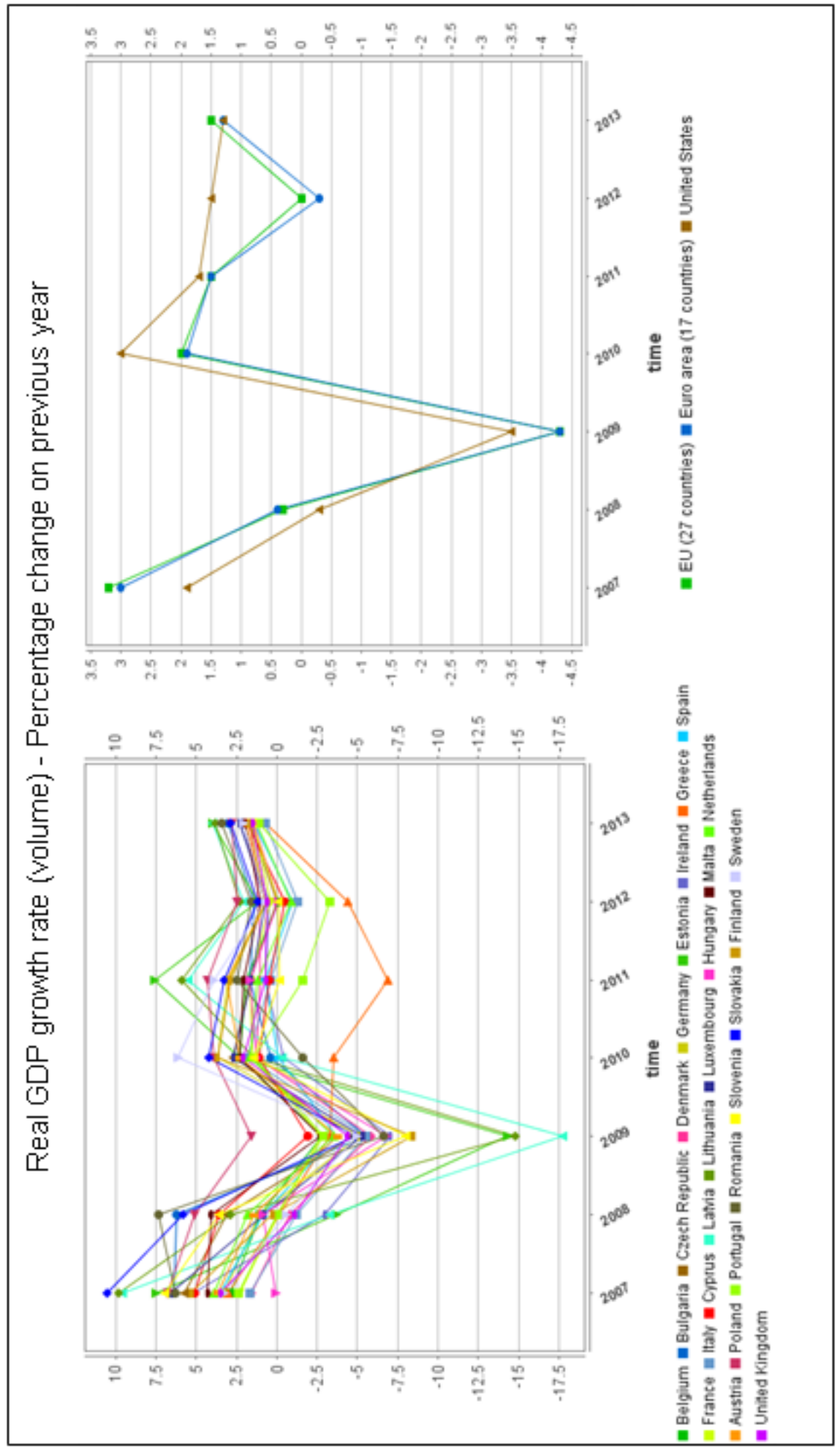

Table 1 - Real GDP growth rate (volume) - Percentage change on previous year. Source: Eurostat. 
Looking more deeply into these cases, all featured bad economic policies ("Europe's Single Debt Zone" 2010), but every country had unique problems and special difficulties. Greece is the most severe case, since it is the only country suffering protracted recession over six years, from 2008 to 2013, caused by the Greek government's unsustainable overspending and subsequent massive debt, plus poor growth. Greece was the first eurozone member to receive a bail-out in May 2010 from the EU, the euro-area Member States and the IMF to ease the dramatic deterioration of Greek financing conditions. The total volume of granted loans received up to 2014 is estimated being $€ 392$ billion, showing the seriousness of the Greek crisis. In granting these loans, the EU, the euro-area members, and the IMF asked Greece to change the structure of its economic sectors, restructure its debt, and enact austerity programs and spending cuts (Enrich and Forelle 2010).

The Irish debt crisis was not based on government over-spending, but from the debatable government move in 2008 and 2009 to guarantee the main Irish banks that were full of bad loans after the burst of the property bubble they had financed (Goff and Jenkins 2010). Even though the Irish government argued that the country did not need any loan to rescue its banking industry, in November 2010 Ireland finally agreed to obtain a $€ 85$ billion bail-out, divided into $€ 22.5$ billion came from the EFSM, $€ 22.5$ billion from the IMF, $€ 22.5$ billion from the EFSF, and $€ 17.5$ billion from the Irish Pension Reserve Fund, as well as from bilateral loans from the United Kingdom, Denmark and Sweden (Goff and Jenkins 2010). The bail-out has been utilized in three ways: $€ 50$ billion for government spending, $€ 10$ billion to recapitalize the banks, and $€ 25$ billion for banking contingencies (Jenkins 2010). The $€ 35$ granted to the Irish banking system has been deemed as "odd" by Goff and Jenkins (2010) and "the height of folly" by the Wall Street Journal ("The Real Euro Danger" 
2010). In December 2013, Ireland officially exited the EFSF financial assistance programme (European Financial Stability Mechanism 2013).

The Portuguese crisis clearly originated from a large budget deficit made by decades of governmental over-expenditure, creating an enormous public debt, overstaffed public servants, redundant and expensive external consultancies, and mismanagement of European structural and cohesion funds ("O estado a que o Estado chegou" 2011). The situation worsened due to poor growth in the last ten years and reluctance of the government to tackle the crisis in a timely manner ("A contagious Irish disease?" 2010). In the first half of 2011, Portugal became the third Euroarea country (after Ireland and Greece), to get emergency funds. In fact, Portugal requested and obtained a $€ 78$ billion bail-out package equally split among the EFSM, the EFSF, and the IMF. In exchange, the Portuguese government agreed to enact severe spending cuts, reform its health care system, initiate privatization programs, and make a dramatic cut in budget deficit.

Spain's economic troubles did not originate from the sovereign debt, since it has a comparatively low debt among advanced economies, mainly controlled internally (Krugman 2012). Further, the country's public debt relative to GDP is under control and fiscally is relatively sound ("The euro crisis spreading from Ireland to Iberia" 2010). In Spain, the crisis was generated by a lack of confidence in its ability to finance its debts (especially long term bonds), huge trade deficit, the crash of the real estate market, banks under stress, meager growth prospects, and a particularly severe increase in unemployment ("The euro crisis spreading from Ireland to Iberia" 2010; “A contagious Irish disease?” 2010). Since Spain is one of the larger eurozone economies, comparable to that of Italy, its collapse would 
originate a domino effect whose ultimately effect might be catastrophic not only for the EU but globally too.

The recovery of Spain is a clear example of how domestic politics matter. Since the Spanish government, led by Zapatero, had been hesitant in successfully tackling the crisis with late austerity measures and a modest labor-market reform, in April 2011 the prime minister called for early election, to be held six months ahead and announced that he would not run for office. This move cost him the post, basically putting to an end his political career, but it saved Spain from further turbulence since after his announcement speculators moved to Italy. The elections were won by the conservative Mariano Rajoy who in July 2012 agreed to accept a $€ 125$ billion euro in rescue loans by the International Monetary Fund and Eurozone members for its banks (Minder, Kulish, and Geitner 2012).

Italy has several structural deficiencies such as the biggest public debt in the Eurozone (more than $€ 2$ trillion in 2013) and a debt-to-GDP ratio (118\% in 2010) second only to Greece (Dinmore 2010). Italy has had decades of severe political dysfunction and fractured politics, with the addendum of loss of competitiveness and limited growth in the last ten years; the latter was insufficient to counterbalance the rise of debt (Alderman 2010). Since Italy is the third largest economy in the eurozone, fears of contagion were particularly acute. Further, the Italian Prime Minister, Silvio Berlusconi, was lacking any credibility after being involved in corruption scandals, splits within his ruling coalition, and scandals over his private life. He clearly had a great responsibility in the poor management of the Italian financial troubles, given the inability of its executive to promote emergency bills and adequate reforms to tackle the rampant economic and financial turmoil that hit Italy hard. After the Italian government experienced parliamentary deadlock in getting the 2010 
government budget approved and interest premiums on governments bonds skyrocketed, Berlusconi finally had to resign in November 2011 when the crisis in Italy reached its apex, precipitating rumors of a generalized default.

Turning to the analyses of the solutions identified to tackle the financial mess analyzed above, since 2008 several options have been debated by European governments, the EU and worldwide institutions to avoid the contagion of the Greek, Irish, Portuguese, Spanish and Italian crises abroad. Among these proposals, up to now consensus has emerged to address the future of the European Union and the euro area on (i) the creation of rescue funds (EFSM, EFSF and ESM) charged with disbursing loans for economies in difficulty, (ii) the "six-pack" reforms targeting a more stringent enhancement of macroeconomic, budgetary, and fiscal surveillance, (iii) the reinforcement of an EU fiscal governance framework comprised of the fiscal elements included in the "Six-pack", the Treaty on Stability, Coordination and Governance (TSCG) and the "two packs", (iv) the unprecedented purchase by the ECB of government bonds refinancing sovereign debts (through SMP and OMT programs), (v) the Euro Plus Pact based on the Enhanced Co-operation procedure, according to which several members can decide on a voluntary basis to advance integration in a specific policy area, and (vi) a banking union introducing a single rulebook, common deposit protection and a single bank resolution mechanism covering all banks in the euro area. Other options were discussed but not adopted, such as the issuance of Eurobonds, the creation of two distinct euro currencies, and the punishment of rules offenders through an eventual expulsion from the Eurozone.

The management and disbursement of loans (generally defined as bail-outs) aimed to provide stability for overly indebted EU and eurozone members has been made possible by 
two temporary solidarity institutions agreed simultaneously in May 2010: the European Financial Stabilisation Mechanism (EFSM), a sort of balance of payments assistance program to any EU member but assumed to be used primarily by euro-area members (European Commission 2012b); and the European Financial Stability Facility (EFSF), succeeded by a permanent European Stability Mechanism (ESM) in 2013, solely intended for eurozone members (European Commission 2012) ${ }^{24}$.

The EFSM, the EFSF (and the ESM since 2013) must be requested by the concerned member and disbursed upon macroeconomic adjustments agreed with the Commission and the ECB (European Stabilisation Actions 2012). Adding together EFSM funds ( $€ 60$ billion), EFSF funds (€440 billion), and funds from the International Monetary Fund (IMF) for euro members ( $€ 250$ billion), the total volume of this massive safety net for eurozone is $€ 750$ billion (Barber 2010a). For euro members, two other stabilization options rely upon (i) possible purchases of bonds refinancing sovereign debt by the ECB (European Stabilisation Actions, 2012), and (ii) pooled bilateral loans by eurozone members decided by intergovernmental agreement. Generally, to be recipient of these assistance channels, a troubled country has to commit itself to fundamental reforms, austerity measures, spending cuts, tax rises, pay cuts, and debt restructuring (Barber 2010a; “A contagious Irish disease?" 2010). Finally, non-eurozone members can get mutual assistance through the Balances of Payments Assistance (BoP), a mechanism already in place since $2002^{25}$. Up to date, the EFSM and the EFSF provided financial assistance to Ireland, Portugal, and Greece (table 2).

\footnotetext{
${ }^{24}$ The legal basis of EFSM and EFSF is the Council Regulation (EU) No 407/2010 of May, 112010.

${ }^{25}$ EFSM could be instituted under Article 122 of TFEU, which allows emergency funds for a member experiencing "exceptional occurrences beyond its control". The feasibility of granting mutual assistance to an EU member with economic troubles as balance of payments assistance is stated in Article 143 of TFEU (ex Article 119 TEC). The
} 


\begin{tabular}{|c|c|c|c|c|c|c|c|}
\hline \multicolumn{4}{|c|}{$\begin{array}{l}\text { EFSM: Loans for } \\
\text { Ireland and Portugal }\end{array}$} & \multicolumn{4}{|c|}{$\begin{array}{c}\text { EFSF: Loans for } \\
\text { Ireland, Portugal and Greece }\end{array}$} \\
\hline Amount & $\begin{array}{c}\text { Disbursed } \\
\text { on }\end{array}$ & $\begin{array}{l}\text { Average } \\
\text { Maturity }\end{array}$ & Beneficiary & Amount & $\begin{array}{l}\text { Disbursed } \\
\text { on }\end{array}$ & $\begin{array}{l}\text { Average } \\
\text { Maturity }\end{array}$ & Beneficiary \\
\hline$€ 15.3 \mathrm{bn}$ & 2011 & $8.8 \mathrm{yr}$ & \multirow{2}{*}{ Ireland } & $€ 7.6$ bn & 2011 & \multirow{3}{*}{$20.8 \mathrm{yr}$} & \multirow{3}{*}{ Ireland } \\
\hline$€ 6.3 \mathrm{bn}$ & 2012 & $16.6 \mathrm{yr}$ & & $€ 4.4$ bn & 2012 & & \\
\hline$€ 15.9 \mathrm{bn}$ & 2011 & $9.2 \mathrm{yr}$ & \multirow{2}{*}{ Portugal } & $€ 5.7 \mathrm{bn}$ & 2013 & & \\
\hline$€ 7.0$ bn & 2012 & $22 \mathrm{yr}$ & & $€ 6.9$ bn & 2011 & \multirow{3}{*}{$20.7 \mathrm{yr}$} & \multirow{3}{*}{ Portugal } \\
\hline & & & & $€ 11.3 \mathrm{bn}$ & 2012 & & \\
\hline & & & & $€ 5.8 \mathrm{bn}$ & 2013 & & \\
\hline & & & & $€ 108.3 \mathrm{bn}$ & 2012 & \multirow{2}{*}{$30.5 \mathrm{yr}$} & \multirow{2}{*}{ Greece } \\
\hline & & & & $€ 25.3 \mathrm{bn}$ & 2013 & & \\
\hline
\end{tabular}

Table 2 - Overview on EFSM AND EFSF loan disbursements (status: February 15, 2014).

The EFSM works as an emergency funding program for the eurozone economies in financial difficulties. EFSM was agreed in an emergency situation at a special summit of the Eurogroup (comprised of the then sixteen heads of state or government of the Eurozone) held on May 7, 2010, which according to the EU procedures, gave to the Commission the mandate "to use the full range of means available to ensure the stability of the euro area" (Statement of the Heads of State or Government of the Euro Area 2010, 2). Two days after that meeting, the European Commission made the EFSM proposal, which ultimately got approved.

EFSM is executed by the European Commission based on funds raised on the financial markets through bond emissions up to $€ 60$ billion. The Commission, then, on-lends the borrowed funds to the beneficiary country (up to date, $€ 22.5$ billion for Ireland and $€ 26$ billion for Portugal), which repays all interest and loan through the Commission, using the budget of the European Union as a collateral guarantee in case of insolvency. Essentially, the

Balance of Payments assistance was established in 2002 by Council Regulation (EC) No. 332/2002 granting of financial support up to $€ 50$ billion. Up to date, it provided $€ 15$ billion to support to Romania, Latvia and Hungary. 
EFSM replicates for the eurozone members the basic mechanics of the existing BoP for noneurozone members (European Financial Stabilisation Mechanism 2012).

The outline of the European Financial Stability Facility (EFSF), authorized to borrow up to $€ 440$ billion, was agreed in April 2010 by Council Regulation and presented at the end of November 2010 (Barber 2010a). EFSF was initially developed by Eurozone finance ministers as a contingent instrument to relieve the Greek debt (Oakley and Milne 2010), but in order to reduce the likelihood of a future crisis, from 2013 onwards EFSF has been replaced by the European Stability Mechanism (ESM), a new permanent crisis mechanism including the involvement of private creditors, intended to reinforce economic surveillance in the EU, and focusing on debt sustainability and effective enforcement measures (European Stabilisation Actions 2012). In September 2012, the German constitutional court ruled that Germany could contribute to the European Stability Mechanism.

In regard to members' preferences, Oakley and Milne (2010) and Hall, Peel and Chaffin (2010), argue that the draft of the EFSF and its evolution towards the ESM is a compromise between the French preference towards a case-by-case approach on future crises to avoid it being considered as a default mechanism and the German determination to conceive it as mechanism with clear rules to be followed by any member, should they need ESM assistance. Germany was a supporter of the inclusion of private bondholders into the mechanism, to ease its burden in helping troubled countries ("Europe's Single Debt Zone" 2010).

Urgent negotiations between Paris and Berlin took place in November 2010 under the supervision of the European Commission, which was initially supposed to present the outlines of the mechanism to the European Council but ultimately had to grant a fast track 
status for the proposal to reassure investors. According to Walker (2010) and Barber (2010a), Germany initially was skeptical about granting bail-outs for troubled eurozone members, preferring an assistance regime based on bilateral loans from other governments, but ultimately reconciled itself with the EFSM and the EFSF to prevent the collapse of the euro (a vital domestic interest for the German recovery), because it would be less expensive to lend money to countries in economic difficulty using multiple channels than propping up its banks full of distressed assets in countries eventually dropping out of the euro. However, in March 2012 the European Council agreed that the ESM funds can be loaned directly to national banks of Eurozone members, under the supervision of the ECB (Buonanno and Nugent 2013).

To become permanent, ESM requires a treaty amendment, since Art. 125 of TFEU clearly states that: "A Member State shall not be liable for or assume the commitments $[\ldots]$ of another Member State". Germany was the first country to push for a treaty amendment to legally allow ESM. In March 2011 the European Council adopted a decision to amend the Treaty by adding a new paragraph to Article 136, which contains specific provisions for euro area members. The additional paragraph, which currently is under the ratification process, affirms that: "The Member States whose currency is the euro may establish a stability mechanism to be activated if indispensable to safeguard the stability of the euro area as a whole. The granting of any required financial assistance under the mechanism will be made subject to strict conditionality".

The ECB decided to back this safety net with an unprecedented initiative to buy government bonds refinancing sovereign debts, following the Federal Reserve and the Bank 
of England which had already take this drastic step to tackle the crisis (Barber 2010a) ${ }^{26}$. Early political negotiations on this topic took place at the special summit of the eurozone leaders that eventually led to the EFSM. The summit showed two visions of the role of the ECB, by treaty law supposed to be independent from political pressures. On one side, the French president Sarkozy, backed by Berlusconi and Sócrates, respectively the Italian and Portuguese prime ministers, spoke in favor for the ECB purchases of government bonds, while the German chancellor Merkel, supported by the Dutch and Finnish premiers, underlined the absolute need not to damage the EBC reputation (and legal status) for independence (Barber 2010a).

Sharply, the then ECB president Trichet warned the leaders "Don't ask me to do anything. We will do what we ourselves judge appropriate" (Barber 2010a:9). Trichet's message was clear: if the ECB would consider the purchase of government bonds, it would be an ECB its own strategy, not a consequence of political pressures. In fact, several days after the ECB effectively launched the government bond-buying temporary program, denominated Securities Markets Program (SMP), deemed as functional to the effective achievement of price stability in the medium term (European Central Bank 2010) ${ }^{27}$. As a matter of fact, SMP so far provided $€ 214$ billion of liquidity for troubled eurozone members.

On September 2012, SMP was replaced by the permanent Outright Monetary Transactions (OMTs). The Governing Council of the ECB announced its intent to conduct OMTs in secondary markets, purchasing sovereign bonds issued by Eurozone members in

\footnotetext{
${ }^{26}$ The other two ECB's responses to the crisis, the series of interest rate reduction and the enhanced credit support, are not taken into consideration in this dissertation because they are conventional monetary measures already enacted not only in times of crisis.

${ }^{27}$ The legal basis of the Securities Markets Program is the Decision of the European Central Bank of 14 May 2010 (ECB/2010/5, 2010/281/EU).
} 
order to safeguard "an appropriate monetary policy transmission and the singleness of the monetary policy" (European Central Bank 2012b). OMT is evaluated by the ECB when a Eurozone government asks for financial aid from one of the bailout funds (EFSF/ESM). The ECB Governing Council is empowered to decide about the start, continuation and suspension of OMT "in full discretion and acting in accordance with its monetary policy mandate" (European Central Bank 2012b). Seemingly, the decision of the European Central Bank to enact OMT was not adopted unanimously, with Bundesbank president Jens Weidmann against it. Weidmann (2012), backed by German economy minister Philipp Roesler, expressed his opposition to OMT because it seemed a de facto credit line from the ECB to troubled Eurozone members, working as a deterrent to the implementation of much needed reforms.

Due to the protracted history of SGP rules violations, the so called "six-pack" reforms (2011) is a set of European legislation (five regulations and one directive) targeting a more stringent enhancement of macroeconomic, budgetary, and fiscal surveillance (Buonanno and Nugent 2013). Upon a proposal by the European Commission, the Council and the European Parliament adopted the legislative package aimed to prevent future crises in the euro area and the EU. In doing so, the Council followed the report of the Van Rompuy Group (named after the President of the European Council), while the European Parliament for the first time participated in the definition of the EU economic governance. The involvement of the EP represented a notable progress for EU democracy, especially because the previous permissive consensus has been replaced by a vibrant debate across parties supporting austerity measures or growth-oriented policies. Institutionally, between 2009 and 2011 the EP established a special Financial, Economic and Social Crisis (CRIS) committee. 
The "preventive arm" of the six-pack regulation did not change SPG parameters but was focused forwards improving the compliance with SGP and enforcing budgetary discipline in the Euro area members since the sanctions are enacted earlier and more consistently than before. The preventive arm consists of several new tools managed by the Commission, the Council and possibly the ECB, if necessary. Every year Eurozone members have to submit a SGP compliance report (officially named "Stability Programme") to the Commission (empowered for supranational review) and the Council of Ministers (providing peer-review). As well, non-Eurozone members have to submit "Convergence Programmes". This means that all $28 \mathrm{EU}$ member states (including Croatia that entered into the EU in 2013) are committed to the SGP. Based on the Stability and Convergence programmes (SCPs), the Commission proposes Medium-Term Budgetary Objectives (MTOs), calculated case by case for each member, who are obliged to identify the adjustment measures it plans to implement to achieve its MTOs. If members do not fulfill their obligations, an Alert Mechanism Report (AMR), working as an early warning system for excessive macroeconomic imbalances, is enacted by the Commission (European Commission 2011b).

The Macroeconomic Imbalance Procedure (MIP), based on AMR, has a preventive and a corrective arm. MIP is a surveillance mechanism identifying countries for which a further in-depth review is considered necessary. The Commission, voting by QMV, can submit recommendations to the member under scrutiny to take corrective action, which can be only overruled by the Council voting, also by QMV. This gradual approach is eventually followed by a corrective arm, which occurs when the Commission takes action in more serious cases and can be reversed by the Council if a qualified majority of members votes against it. The Excessive Imbalance Procedure (EIP) can be opened for a member not 
fulfilling either debt or deficit parameters; this replaces the former Excessive Deficit Procedure (EDP), which was not including sanctions for excessive debt. If an EIP procedure is opened against a country, an interest-bearing deposit in the amount of $0.2 \%$ of GDP is due. If non-compliance persists, the deposit is converted into a fine. Sanctions are also imposed to countries reporting false data (European Commission 2011b).

EMU reforms included the Euro Plus Pact (EPP), adopted by the European Council in March 2011. EU members voluntarily joining the EPP commit to enact domestic political reforms finalized to improve their fiscal strength, improve fiscal harmonization (developing a common corporate tax base), boost competitiveness, and strengthen economic governance with more stringent benchmarks than the Stability and Growth Pact, which has not been implemented thoroughly (European Council 2011a). Since it is based on the Enhanced Cooperation procedure (Article 326-334 of TFEU), several members can decide on voluntarily basis to advance integration in a specific policy area falling within countries' competence. Given such flexibility, in EPP there are three kinds of participants: (i) all the eurozone members, (ii) the big majority of non-eurozone members, and (iii) Denmark, which has a legal opt out from the euro. Currently, non-participating EU members are the United Kingdom (traditionally euro-skeptic), Sweden (to safeguard its collective-bargaining system), Hungary (to maintain sovereignty on its taxation policy), and the Czech Republic (not attracted by fiscal harmonization) (“The euro crisis grounded" 2010).

The creation of Eurobond (or Stability Bonds, E-bonds) by a pan-European agency tentatively named European Debt Agency (EDA) backed collectively by all eurozone countries, was proposed at the end of 2010 by Luxembourg and Italy's finance ministers (Juncker and Tremonti 2010). Since Germany opposed the idea, fearing that it would become 
a de facto paymaster to cover other members' profligacy, this proposal has not been enacted (Forelle and Walker 2010). EDA would finance members' debts with financial stress offering Eurozone members the possibility to switch domestic bonds for E-bonds at a discounted price. The EDA was supposed to enhance budgetary coordination within the Euro area and reinforce its financial stability, as well as finance troubled members at optimal costs, which is the typical mission of a national debt agency (Juncker and Tremonti 2010). Other commentators associate EDA with the European Investment Bank (EIB), owned by all the member states, which issues guarantee bonds to finance European infrastructures designed to improve cohesion and solidarity (Nixon 2010).

Another possible solution suggested by many analysts but not adopted because deemed as destabilizing was the creation of two different euro currencies, a sort of euro of the strong and healthy economies (possibly including Germany, Belgium, the Netherlands, Luxembourg, Finland, and Austria) and the euro of smaller or troubled economies (possibly including Italy, Spain, Greece, Slovakia, Slovenia, Cyprus and Estonia). A survey published in 2010 by the European Commission underlined a "two-speed eurozone", defined as the increasing economic gap between the recovery of core countries (geographically located in Northern Europe) and the troubles of Eurozone periphery dealing with austerity plans (Pignal 2010).

In late 2010, the European Council discussed the opportunity to apply financial penalties to rules offenders. The range of the penalties and their applicability were debated extensively. France agreed as well to support Germany in its demand for a revision of EU treaties to give a legal status to tougher rules. But to please the French government - backed by Italy and Spain -, Berlin had to back away from the request that rules infringers should 
face automatic or quasi-automatic financial penalties or, at the extreme, political sanctions such as voting restrictions, or the expulsion from the euro-club (Barber 2010c; Walker 2010; Weathcroft 2010). Since voting restriction was banned by the Lisbon Treaty, an option would be a majority vote in the Council to exclude infringers from specific votes.

The reinforced EU fiscal governance framework represented a further attempt to centralize fiscal policy at the EU level. This framework is comprised of the fiscal elements included in the "Six-pack", the Treaty on Stability, Coordination and Governance (TSCG) in the EMU (commonly referred as "Fiscal Compact"), and the "two packs" (Buonanno and Nugent 2013). Taken together, run concomitantly and in parallel, from different legal basis and addressing different recipients, all of them are tackling the fiscal mismanagement underlining the debt crisis. The six-pack (five regulations and one directive) is EU secondary law applying to all the member states and aimed at strengthening the Stability and Growth Pact (SGP). The two-pack consists of two regulations applying only to euro area members only (based on Art 136 TFEU).

The Treaty on Stability, Coordination and Governance (TSCG) in the EMU, initiated as an intergovernmental treaty, represents a stricter version of the previous Stability and Growth Pact (SGP). The TSCG was signed on March 2012 by all member states of the EU, with the exception of the Czech Republic and the United Kingdom that abstained - and entered into force on January 2013 after 16 members had ratified it (European Council 2013). Since two countries refused to sign it, at the moment it is an international treaty outside the EU legal framework. The fiscal compact establishes the mandatory introduction of a balanced budget rule and an automatically triggered correction mechanism at the national level as well as a strengthening of the automaticity of the excessive deficit procedure 
within the Stability and Growth Pact, in case a euro area country breaches the deficit criterion (European Central Bank 2012a). If the European Commission concludes that a member violated its fiscal obligations breaching deficit or debt rules, under the legal basis of the Fiscal Compact the matter will be brought to the Court of Justice of the European Union (CJEU) which has the ultimate power to impose penalty payment.

In order to tackle vulnerabilities in the banking sector, which had a negative impact on the sovereign debt crisis, and the negative feedback loops between troubled countries' budgets and some of their failing banks, in September 2012 the European Commission (2012) published a proposal for a European Banking Authority (EBA) backed by the Vice President of the European Central Bank Vítor Constâncio (2013) and the European Parliament. The Commission proposed a Single Supervisory Mechanism (SSM) for banks steered by the European Central Bank (ECB) aimed at strengthening EMU. The "banking union" covering all banks in the euro area (approximately 6,000) also includes a single rulebook, common deposit protection and a Single Resolution Mechanism (SSM ). The legal basis is found in the Treaty on the functioning of the European Union (TFEU, article 127(6)) which specifies that supervisory tasks can be conferred on the ECB. This creation of a single supervisory mechanism is targeting policy homogeneity, financial stability, and the minimization of the cost in case of bank failures. 


\subsection{Conclusion}

This historical chapter highlighted long-term facts and processes seen in the overall history of EMU. This chapter used time as central vector of change, shedding light on the causes of the existence of EMU - i.e. "why" it has been developed. This has to do with the third hypothesis of my dissertation. Concerning the motives triggering the successful push for further integration, I adopt and extend the finding of Künhardt (2013) when arguing that crises affecting the survivability of economic integration should be seen as engines of progress throughout the history of European integration. For Künhhardt, crises have frequently destabilized the existing status quo instigating the need for a reaction, which often was finalized to strengthen European integration. The alternative hypothesis is that any major crisis erupting in the international system undermines European integration, causing a return to state-centric sovereignty or intergovernmentalism, as widely reported by media. With specific reference to EMU, the most extreme consequence would be the collapse of the monetary union together with serious risks for the survivability of the EU.

Building on this dialectic logic of challenge and response, von Hagen (2013) identifies two waves of economic and monetary integration. The first one is the creation of the European Economic Community in 1957 and the Customs Union fully achieved at the end of the 1960s as a cooperative response to World War II and the subsequent Cold War. The second trend occurred in 1979 with the launch of the European Monetary System as an arrangement to stabilize European currencies after the collapse of Bretton Woods in 1971, which brought about a decade of widespread monetary instability in Europe. 
This approach throws new light on the more recent evolution of economic and monetary integration. In this regard, I assume that other three waves can be identified after the two just described above. The third one consists of the attainment of the Single Market in 1992 can be seen as a direct response to the rising competitiveness of the Japanese economy in the 1980s. the fourth one, as already noted by von Hagen (2013), is represented by the achievement of a monetary union was a direct consequence of the end of the Cold War that caused fears in Europe towards a too powerful Germany after its unification. These tensions were resolved with the project of sharing a currency complementing the single market. Finally, I believe that the fifth wave is taking place with the current attempt to seek a fiscal and banking union, together with the enhancement of macroeconomic and budgetary surveillance and the rescue funds mutualizing the risks of a sovereign default, represents an integrationist reaction to tackle the rampant economic and financial turmoil that hit hard the eurozone since 2009. Summing up, I assume that any major systemic economic, monetary, and financial crisis across seven decades since WWII has constituted a turning point in advancing further integration. It derives that this integration has been always seeking supranational solutions, in line with the nature of the challenge, despite the - sometimes obstinate - resistance of EC/EU members who were able to retain a great deal of power. The historic chapter of this dissertation will highlight this balance of power between constituents units and centralized government in economic and monetary issues, a balance that can be identified as a federalist system. 


\section{Explaining Economic and Monetary Union: Various Approaches}

\subsection{Introduction: Supranational, State-Centric and Mixed Paradigms}

As I should have made clear from the previous chapter, a common denominator adopted in this paper is that the overall history of EMU is depicted as an economic policy determined by politics (Tsoukalis 1977; Jones 2002; Dyson 2002b; Featherstone and Radaelli 2003; Dinan 2005; Hosli 2005). In this sense, this dissertation gives a great emphasis to institutional building and political negotiations occurred during the EMU integration process as a result of the preferences of both ECC/EU institutions and domestic politics. Inevitably, this dissertation broadly focuses on the integration theories available to explain the overall evolution of EU, and more specifically, on how these theories explained EMU. More specifically, EMU has already been analyzed by all the mainstream theoretical perspectives, such as neofunctionalism, intergovernmentalism, MultiLevel Governance, Europeanization, and theories focused on Domestic Politics, with a notable exception, since a fully developed investigation applying federalism to the EMU has not yet been $\operatorname{made}^{28}$.

Considering that the EU involves multiple relationships among its members, and a feedback loop between the EU and its members, the departure point for all these approaches is the IR debate introduced by Waltz (1959) who proposes a three-images view of looking at international relations behavior, mainly inspired by realist theory. The first image was the individual and human nature, the second image the nation-state, and the third image the international system, ultimately depending on the previous two. This dynamic has been

\footnotetext{
${ }^{28}$ For instance, another possible research design could be the comparison of the explanatory power on EMU of three mainstream international relations theories, such as neorealism, neoliberalism, and constructivism.
} 
challenged by Gourevitch (1978) when coining the term "second image reversed" in his neoliberal re-examination of Waltz's work, aimed to look at how international politics affect domestic structure. Finally, Putnam (1988) reconciles domestic and international imperatives simultaneously, recognizing that states define their policy preferences at home, and simultaneously bargain inter-state on the international stage. In such logic, it derives that international agreements will be successfully realized only if they result in domestic benefits.

The debate over the predominance of domestic or supranational factors in European integration has seen recent permutations, as I will make it clear in the literature review section, but earlier analyses inspired by the international relations debate can be found since the 1960s. Scholars already emphasized the integration process from different perspectives. For instance, Beloff (1974) dealt with the political crisis of the European nation-state; Ionescu (1974), Luxemburgensis (1974), and Deutsch (1974) identified the emergence of a European sovereignty; Diebolt (1962) and Bowie (1962) analyzed the rise of an emergent federalism within the EEC; and Friedrich (1962) argued that federalism was legitimized on constitutional basis. Some other scholars clearly dismissed the importance of any supranational project emphasizing the pivotal role of the nation-state (Puchala 1971). Finally, others identified interdependence as an option between sovereignty and supranational integration (Spiro 1974). The latter concept is the closest one resembling what today is the mixed paradigm studying European integration, which envisages a balance of power between the EU and its members.

This dissertation draws on the assumptions found in the mainstream literature on European integration, which I believe it can be divided in three broad paradigms, as highlighted in table 3. Following the spectrum between the EU and its member states (and vice versa) introduced above, some investigations adopt a supranational paradigm, envisioning a decisive 
role of the ECC/EU towards promoting further investigation. In this regard, I assume that the only supranational approach is neo-functionalism. Two others (intergovernmentalism and domestic politics) can be classified as state-centric since they emphasize the predominant role of the state, broadly defined. Finally, I claim that federalism, Europeanization, and Multi-Level Governance belong to the mixed paradigm, which by definition merges both approaches. Such theories sometimes conflict with each other and sometimes partially overlap, but all have some weaknesses that will be overviewed in this chapter.

\begin{tabular}{|c|c|}
\hline Paradigms & Theories \\
\hline \multirow{2}{*}{ Supranational } & Neo-functionalism \\
\hline \multirow{2}{*}{ Mixed } & Federalism \\
\cline { 2 - 2 } & Multi-Level Governance \\
\cline { 2 - 2 } & Europeanization \\
\hline \multirow{2}{*}{ State-Centric } & Intergovernmentalism \\
\cline { 2 - 2 } & Domestic Politics \\
\hline
\end{tabular}

Tab. 3 - Classification of mainstream theories in three broad paradigms.

This chapter proceeds with a literature review on the mainstream theories adopted to study European integration (Rosamond 2000; Wiener and Diez 2003; Pollack 2005). Section 5.2 of this chapter is dedicated to neo-functionalism (the only supranational approach I have identified). Section 5.3 highlights two state-centric paradigms (intergovernmentalism and domestic politics). Section 5.4 introduces two mixed approaches (Europeanization and Multi-Level Governance). Each of the following sections is divided in three parts: the first one presents the general assumptions of the theory and its recent permutations; the second one focuses on specific investigations adopting that theory to explain the EMU; and the last one reports major limits of that theory when applied at the EMU case. The conclusion will discuss why mixed theories provide a better understanding of EMU. 


\subsection{Supranational Paradigms}

\subsubsection{Neo-functionalism}

In the 1950s, neo-functionalism was the first theory trying to explain European integration, especially in the economic realm (Tsoukalis 1977). The traditional theorization proposed by Haas (1958) and Lindberg (1963) presupposed a functional spillover across economic sectors, following the cumulative logic according to which integration in one policy necessarily leads to integration in a neighboring policy. More recently, the idea of spillover has been expanded in various directions by Tranholm-Mikkelsen (1991) who elaborated the idea of political spillover

- usually an outcome of a deliberated political process when elites realize that supranational cooperation could be the best approach to solve domestic problems -, and cultivated spillover, when supranational actors promote a supranational framework. More recently, Niemann (2006:37) proposed the idea of social spillover, resulting from public opinion socialization over certain policy issues.

According to Piattoni (2010) neo-functionalism posits that the same forces that produce global interdependencies also generate (supranational) institutional solutions. As such, the "inevitable chain reaction" identified by neo-functionalists should have taken place from a customs union, to a single market, to a single currency, and finally to a single fiscal policy, as suggested by many commentators. However, this has not been the case as yet, especially referring to the reluctance of building a fiscal union, hence neo-functionalist determinism has failed to provide an adequate prediction on this matter. In fact, it cannot explain why fiscal policy is still determined domestically and economic policy has not been exclusively centralized at the EU level yet, even if this reluctance towards deeper integration in economic issues is about 
to change in the near future. In chapter 4 , in fact, I made it clear that in order to tackle the current economic and financial crisis, the EU is moving towards a fiscal compact, and a possible banking union and supranationalization of sovereign debts. However, I believe that the economic determinism of neo-functionalism (even if partially corrected by the political and cultivated spillovers add-ons discussed above), still fails to explain the peculiar political maneuvers standing behind the envisioned solutions.

Another principle introduced by Haas (1958) and Lindberg (1963) was the central role of supranational actors in promoting incremental integration, the crucial role of elites, and the nature of technocratic decision-making relatively free from political interference. In this regard, neo-functionalists emphasized the role of the High Authority, and later the European Commission, as a political broker to advance integration. These institutions, working independently from domestic interests, were supposed to represent the supranational standpoint, solving deadlocks, seeking compromises, building coalitions during existing negotiations among members' governments, and identifying new areas where integration could be extended (Tsoukalis 1977; Maes 2006). In order to persuade recalcitrant governments towards a certain solution deemed as detrimental for domestic interests, Tsoukalis (1977:25) observes that the method of "package deals" was used extensively to bridge a compromise between domestic and supranational pressures. This method consisted of providing a sort of side payment in an unrelated field for a government willing to give up its resistance against a common provision under discussion. Tsoukalis (1977) observed that given its political ramifications, economic reverberations, and monetary interests at stake, EMU ideally represented the perfect case for these kinds of deals, even though in reality it showed some limitations. 
The neo-functionalist assumption, according to which politics are relatively irrelevant in the managing of economic and monetary policies, appears controversial when applied to EMU. As I already highlighted in the introduction, many commentators stressed the inherent political nature of EMU, since political negotiations predated (and therefore made possible) integration in economic and monetary issues. It derives that federalism, emphasizing the institutional setting, the constitutional status and the political reverberations of the integration process, is better suited than neo-functionalism to explain EMU.

Another concept introduced by neo-functionalists strictly related to the role played by technocrats is the so called system of "engrenage" (Tsoukalis 1977), which represents one of the earliest theorizations shedding light on the role of non-governmental actors in the EEC decision making process. In this regard, the Commission pushes to engage as many people as possible in the Community system, such as experts, civil servants, and representatives from parties and private businesses. The venues where this exchange of views and advising took place were the committees, and in the case of EMU, the ideas discussed in the Monetary Committee established by the Treaty of Rome influenced attitudes towards integration and policy, despite several limitations restricting the success of this method (see Coombes 1970).

As a consequence of these basic assumptions, for neo-functionalists each country achieves policy maximization at the supranational level. In such a way, the perception of a common interest, taken at its most extreme, equates to considering countries' preferences as a black box between the integration process and policy spillover. This meant that domestic politics were largely ignored by neo-functionalists, an aspect that represented a major explanatory weakness of this approach which has been partially corrected later, when the original accounts provided by Haas and Lindberg were further elaborated by Schmitter (1969), Nye (1970), and 
also by Haas (1970) and Lindberg (1971) themselves. The deterministic nature of spillover has been lifted and replaced by a more discretionary appraisal, delimitating its occurrence under certain qualifications (Niemann 2006). In its more recent permutations, scholars (cf. Burley and Mattli 1993; Borzel 2006) have focused on the reasons behind integration, expanding their analyses on the role of not just supranational actors, but including societal actors and national governments as well. In doing so, they diluted the focus granted by initial analyses on the prevalence of non-state actors, and made neo-functionalism a theory that ultimately merged together the original "pure" supranational orientation with some "residual" intergovernmental features, which suggest for the inclusion of neo-functionalism within the family of mixed theories. While these latest reformulations of neo-functionalism remarkably increase its leverage, it must be noted that they are distorting its intrinsic assumptions and original meaning.

In EMU, neo-functionalist traits emerged following the assumption that using a common European currency would derive a functional advantage by reducing risks related to trading within a single market and protecting companies from the speculations associated with fluctuations in national currencies (Verdun 1999). As observed by Leonardi and Nanetti (2007:296), it derives that neo-functionalism is only able to depict the intra-policy transition (and the growing complexity) from the European Monetary System to the EMU.

I argue here that neo-functionalism is also able to depict successfully the technocratic execution of monetary policy by the European Central Bank (ECB), which is supposed to be independent of politics. However, it fails to explain why even a policy like EMU is broadly managed by a shared quota of national and supranational institutions while being exclusively executed at EU level, in several stages (such as treaty revisions and euro adoption). As said earlier, Verdun (2002) and Wolf (2002) concluded that by taking only together the 
neofunctionalist and intergovernmental approaches, in an eclectic fashion, the whole picture of the EMU can be portrayed to counter criticisms against both approaches. Finally, contrary to neofunctionalist normative assumptions, the recent rounds of enlargement (membership widening) might constitute a problem for policy deepening and spillover, since several countries such as Poland and the Czech Republic did not embrace EMU even if they potentially could (“Poland and the Euro, Augustinian Delay" 2012).

While the traditional practice of close links and cooperation among central banks fits the neo-functional approach, Tsoukalis (1977) notes that it failed to explain the eminent political nature of EEC monetary issues and the complex negotiation network among the governments of the EEC/EU members which occurred behind any decision to bring about progress in monetary integration. Further, monetary policy was considered a prerogative belonging to national sovereignty and currencies represented sensitive symbols of national pride (Müller-Peters 1998). Thirdly, the nature of exchange rates was highly political since they worked as policy instruments to redress economic cycles and tackle speculative attacks (Ungerer 1997). This lack of leverage is particularly severe for neofunctionalism, since monetary policy is a field that neofunctionalists identified as typically insulated by politics and managed by technocrats and experts. Finally, Ungerer (1997) opposed this neofunctionalist assumption, contending that there were no automatic mechanisms through which are harmonized much diversified economic and monetary policies, in contrast to the creation of a customs union, where duties, trade restrictions and external tariffs could be harmonized quantitatively in a phased way.

A final word is for the subtle distinction between neo-functionalism and federalism. The idea of Haas (1958) and Lindberg (1963) concerning a functional spillover across policies, following the logic according to which integration in one policy necessarily leads to integration 
in a neighboring policy, can been seen as close to a federal dynamic. In this regard, Haas (1971) suggested that neo-functionalism can be seen as the mechanism towards the attainment of federalism-in-action, while federalism has a more normative underpinning, focusing on the outcome of integration.

\subsection{State-Centric Approaches}

\subsubsection{Intergovernmentalism}

Since the 1960s, intergovernmentalism represented one of the mainstream general theories providing a powerful conceptual account of the European integration process. Theoretically informed by Realism, and inherently challenging neofunctionalism, the classic intergovernmental approach is centered on the vision according to which states are the main actors in EU integration, which is ultimately driven usually by conflicting domestic interests. As such, state sovereignty remains crucial and any integration process outcome is seen as a zerosum game. Prescriptively, the EU is seen as an international organization, where constituent members (the Council of Ministers until the 1970s plus the European Council thereafter, both formed by domestic governments) rather than the central authority retain decisive power. And at its very best, inter-state cooperation could be merely finalized to pooling, sharing, and delegation - but not full transfer - of sovereignty at the supranational level. It meant domestic decision makers kept the legal decision to make decisions without being subject to external restraints. In the ultimate analysis, it can be said that in integration, the independent actors are the memberstates and the EU is the dependent actor. Particularly since the 1970s the European Council, 
being essentially formed by domestic governments, is eminently willing to accommodate member states' interests as opposed to those of the EU. Further, the role of the heads of governments through the European Council is pivotal in the definition and revision of the treaties, the long-term rules under which EU policies have to be delivered.

Inspired by Realism, in the 1960s the "Power Politics" school has been one of the first ones to highlight the importance of domestic factors even when dealing with supranational integration. Aron (1964) and Hoffman (1965) assumed that the nation-state is the only important actor in the international system, and as such, international organizations are seen as the sum of nation-states' preferences. In short, there is no room in the theory for supranational institutions, whose importance is seriously dismissed as the byproduct of conventional inter-state politics. An example of this approach is represented by Rosenstiel (1964:128), according to which considering the Commission as a "federator" institution was "theoretical barbarism".

More recently, inspired by the neo-realist stream introduced by Waltz (1979), understanding some potential for order on the basis of international cooperation, Moravcsik (1998) provided a revision of this approach, famously defined as Liberal Intergovernmentalism (LI). However, the theory remains inspired by more classical realist elements when stating that there is no evidence that supranational institutions move the decisional process away from the self-interests of members. Stressing the importance of the system (in this case the EU institutions) in facilitating a positive-sum bargain, and observing that states are rational actors willing to maximize gain, it can be said that LI incorporates both neo-liberal elements also, as defined by Keohane (1989). Monetary cooperation and setting up of the European Monetary System (EMS) from 1969 to 1983 is one of the cases analyzed by Moravcsik, which is assumed to be driven by domestic national interests. He identifies three major factors driving European 
integration: (i) configuration of state preferences at the economic level, followed by (ii) interstate negotiation where relative bargaining power matters, and finalized by (iii) institutional delegation, which is made possible only when inter-state commitments achieve a level of consolidated credibility to the point of developing supranational institutions.

Hoffman himself (1995) constantly elaborated on his initial approach (Hoffman 1965) and further reappraisals aimed to illuminate the real effects of integration disclosed that the statecentric premise of intergovernmentalism moved far beyond the mere pooling of sovereignty. Pierson (1996) introduced the idea of a path dependent process of European integration which locked states to each other under the EU umbrella. Joint-decision trap (Scharpf 1988:256), "locking-in of states" (Risse-Kappen 1996:60-1), and "unintended consequences" (Wiener-Diez 2004), are all concepts that have in common a similar vision of the effects of EU integration. Despite the fact that these reappraisals do not share the same positivistic tone as those offered by neofunctionalists (which are very much integration-oriented), they all had to admit that traditional intergovernmentalism became limited in portraying a growing number of EU aspects.

Empirically, intergovernmentalism associated with EMU can be observed in various ways. In EMU, intergovernmentalism has been able to explain the idea of monetary union up to the three step convergence (Maastricht pact). In such a way, as observed by Hosli (2000), the negotiated decisions that led to the establishment of the EMU, such as institutional structure, the timing of its establishment, and the allocation of policy powers, were mainly a byproduct of EC governments' preferences. Cameron (1998) traces the emergence of new European organization structures in the monetary realms, adopting a sort of intergovernmentalist explanation bringing about Multi-Level Governance as an outcome. In fact, he argued that member-states perceived the necessity to create new institutions at the supranational level to better serve their interests. 
Idiosyncrasy is the concept used by Jones (2002:1) to define the controversies that have surrounded the creation of the EMU, because "the politics of EMU [...] varies from country to country and from one situation to the next". The author argues that divergences toward the EMU embraced the significance of the broad change instilled in the member-states and the EU, made more difficult by the coexistence of different actors, interests, institutions and time.

Immediately after the failure of the Werner Plan, Tsoukalis (1977:170) wrote that "the Community has gradually evolved towards a more intergovernmental type of organization". Despite intergovernmentalism being particularly persuasive in depicting the early evolution of economic and monetary integration, since the governments and the Council were the most empowered institutions to move integration forward (or backward), several limits need to be recognized. The main critique is that intergovernmentalism dismissed the role and significance of the European Commission as an independent entrepreneur pushing for the process of European integration (Andrews 2002; Maes 2006). This critical appraisal targets Moravskic (1998:9) when he argues that "the entrepreneurship of supranational officials [...] tends to be futile and redundant, even sometimes counterproductive". Similarly, Dyson and Featherstone (1999) downplayed the role of domestic interests while setting EMU rules, paralleled by the decisive contribution of communitarian institutions such as the EC Monetary Committee and the Committee of the Central Bank Governors.

The historical overview provided in the previous chapter provides other evidence suggesting other limits of intergovernmentalism in order to explain the role of other supranational institutions such as the various Committees of the Commission (Monetary Committee, the Committee of Governors of the Central Banks, the Budgetary Policy Committee, and the Medium-Term Economic Policy Committee) and the European Parliament. Also, the 
Governors of central banks of the six members favored the deepening of monetary cooperation. The traditional practice of close links and cooperation among central banks generated in a transnational arena had obvious supranational reverberations - the above-mentioned push for more integration in monetary affairs. Finally, the role played after WWII by the United States in European affairs -including monetary integration -, and the activism of federalist supporters have been neglected by intergovernmentalism.

Another common fact is that all EEC members were experiencing a post-WWII economic boom that helped to bypass national differences. The risks of uncoordinated domestic economic policies in the 1960s, causing rising tension in an emerging common market and associated with turbulences in the international monetary system, showed that the improvement of cooperation in economic and monetary issues became an inherent domestic interest. Furthermore, even if different visions towards monetary policy clearly emerged at the domestic level, including various issues such as the debate between monetarists and economists, and the opportunity to adopt either a fixed or flexible exchanges rate regime, these apparently contradictory views cross-fertilized each other and often a policy solution constituted a compromise between the two (Ungerer 1997; Verdun 2010).

However, since the practical execution of monetary union at the EU level in 1999 (which is highly centralized and managed by an independent institution such as the European Central Bank), it is clear that in the monetary realm the EU went far beyond a traditional international organization, which by definition has limited powers over its members. In this regard, commenting on the future evolution of economic and monetary integration, Tsoukalis (1977:173) observed that "in most cases the desired results could be achieved through some form of intergovernmental co-operation [...]. On the other hand, in the monetary field one could expect a 
Monetary Fund to play an important role starting with some pooling of reserves and gradually acquiring the powers of a European Bank". Consequently, on this matter, intergovernmentalism was experiencing a sort of theoretical black-out, given that the theory of institutional delegation advanced by Moravscik (1998) proved not to be adequate in portraying a complete shift of sovereignty in monetary policy and the reconfiguring of supranational institutions aimed at enacting such policy.

As a prescriptive approach, hence, intergovernmentalism advocates the EU as an international regime constituted by national interests and preferences, reducing or limiting a greater role for EU institutions such as, in the case of EMU, not just the Commission, but also the European Central Bank. Following this assumption, it is clear that intergovernmentalism fails to explain the institutional reconfiguration of EMU giving more powers to EU institutions, the subsequent execution of monetary policy at the EU level, and the loss of monetary sovereignty from its member-states.

Intergovernmentalism can only partially elucidate what happened since 2008 in the Council to tackle the ongoing EMU Crisis. As always, it explains the intergovernmental method adopted by the Council to modify treaties and provide innovations in the EU, and more specifically to issues related to EMU. However, it cannot explain the federalist nature of the decisions taken - the European Stability Mechanism, Securities Markets Program, the Euro Plus Pact, and the Fiscal Compound - targeting more centralization from a polity, policy and political standpoints. Other problematic aspects of intergovernmentalism are some treaty reforms aimed at crafting the entry of accession members, and current negotiations on whether the European Council should enforce the monitoring and sanctioning mechanism for members' violations of EU rules - the Stability Pact in the case of EMU. These two factors are challenging 
intergovernmentalism because they denote a further shift of sovereignty towards EU institutions, with the intent of monitoring the effective fulfillment of the EU legal obligations within domestic jurisdictions and achieving a synchronization of economic cycles among members.

For sure, intergovernmentalism can explain the shortcomings and the unwillingness of EEC/EU members to make significant progress towards the supranationalization of economic and monetary policies, despite their formal reiterated commitment over time. However, if this supposed predominance of domestic factors is encapsulated in a broader framework, it is evident that the setting up of a single market and a common currency was an arduous and time consuming process, leaving no room for any kind of shortcut. As I have made clear, there are various aspects that cannot be properly explained by intergovernmentalists, especially with reference to the EMU, where members gave up sovereignty in monetary policy, a process that goes much beyond the supposed pooling or delegation. Particularly, a possible return to pure intergovernmentalism in the execution of EMU, from a polity, policy and politics perspective, would probably mean the failure of the EMU itself.

In order to mitigate the shortcomings of intergovernmentalism, in my research design I adopt Verdun's (2002) and Wolf's (2002) standpoint when concluding that by taking the neofunctionalist and intergovernmental approaches together, in an eclectic fashion, the whole picture of the EMU can be portrayed to counter criticisms against both approaches. As I will made it clear later, it is my understanding that federalism, defined as a mixed approach equally emphasizing the importance of both domestic and supranational factors, represents a proper solution to the theoretical puzzle presented by the overall evolution of EMU. 


\subsubsection{Domestic Politics Theory}

"Euro Fatigue Takes Hold" headlined the Wall Street Journal in 2007 (Hannon 2007), just before the economic turmoil, underlining that the "[c]ommon currency offers few incentives for new EU members [and] membership into the euro zone has failed to generate a significant level of popular enthusiasm". The newspaper also reported a statement released by the International Monetary Fund arguing that "growing skepticism about benefits from euro adoption and reform fatigue [...] contributed to a weakening of political support for euro adoption". These warnings became more severe in the light of the economic and financial turmoil that has affected several European countries and the overall stability of the Eurozone since 2008.

These headlines highlight the predominant role of domestic factors in endorsing or rejecting EU inputs when it comes to playing the EU game. This approach, conventionally denominated Domestic Politics Theory, is aimed at providing in-depth case studies shedding light on important domestic factors usually underestimated by supranational neofunctionalism. Conversely, mixed approaches such as Europeanization, Multi-Level Governance and federalism take domestic arenas seriously, even if they are analyzed in a broader context including supranational pressures.

It might be argued that, while intergovernmentalism looks at the 28 domestic governments working together as European Council or Council of Ministers, domestic politics theory analyzes attitudes toward the EU by members' governments taken singularly, as units, while working in their domestic environments. A plethora of important studies (Huelshoff 1994; O’Neill 1996:54-8; Bulmer 1998; Rosamond 2000:151-5; Hix 2005), have 
highlighted the importance of domestic factors shaping EU attitudes, including regime type, institutional architecture, national elections, the change of governments, political parties' ideologies, public opinion attitudes, policy styles, interest groups, culture, symbols, political discourse, norms and rules, media coverage, administrative, legal and technical factors, and, last but not least, the economic situation.

Looking at EMU, differentiated responses to the pressures coming from monetary union call for a state-centric research project emphasizing the prominent role of domestic factors in endorsing or rejecting what has been decided at the EU level (van Esch 2002; Dandashly and Verdun 2009a, 2009b). The assumption is that policy towards the euro is decided by governments upon such factors reported above. Furthermore, very influential domestic actors usually have the last say in the states' decisions and preferences. With reference to old members, Dyson and Featherstone (1999) and Dyson (2002a) provide detailed accounts on domestic preferences of some old members, even though it is within the Europeanization framework. More recently, Dyson (2007, 2008), Dandashly and Verdun (2009a, 2009b), and Kostadinova (2009), provided in-depth case studies of new members, analyzing domestic preferences and further developments or reluctance towards EMU from an economic, political, and policy perspective. Other studies focused on new members' attitudes toward the EMU, highlight the crucial importance of domestic cost-benefit analyses (Johnson 2008), and pressures coming from public support or opposition for the Euro from eight new members (Allam and Goerres 2008).

Other studies focus on the regime type characterizing the members of the eurozone and the correlation with the EU itself. On this regard, Dyson (2002b:18-22) identifies the challenge for the governments of social democracies to face the neo-liberal pressures coming 
from the ECB towards regulation, stabilization and more efficient labor markets, wages and welfare. The way to get these goals, as proposed by the EU, is to minimize as much as possible the interventionist role of the state in the economy and promote further liberalization of products and service, two tasks which conflict with the economic beliefs typical of social democracies. Here it must be noted that Dyson presupposes a feedback loop between domestic politics and the monetary union, hence his analysis is not merely state-centric. Another aspect analyzed by Dyson (2002b) is the difficulty to manage domestic opinion towards the monetary union for both centre-right and centre-left governments, regardless of any ideological orientation. More generally, Elster, Offe and Preuss (1998) look at the institutional design occurring in post-communist societies, which is peculiar if compared to other European countries. Even if they do not focus specifically on the monetary union, they offer a critical standpoint on which to work to find possible correlations between a very specific regime reconfiguration put into practice in Central and Eastern Europe and the adoption of the eurozone.

Focusing on the prevalence of domestic factors is particularly persuasive in explaining attitudes of the 12 Old Member States (OMS) toward the adoption or rejection of the euro in the 1990s, during the negotiations of the rules of the monetary union itself. As a result of the "idiosyncrasy" (Jones 2002:167-182) already discussed in the previous section to define the heterogeneous interests and politics toward EMU from country to country, the United Kingdom and Denmark legally opted-out, and Sweden informally got an informal opt-out, which has been protracted and is not expected to end anytime soon. The concept of idiosyncrasy has been recently developed in a more sophisticated fashion with the “differentiated integration" approach (Dyson and Marcussen 2010; Kölliker 2006; Kunstein 
and Wessels 2013) that emphasizes the differences among members' fulfillment of EU membership criteria and the uneven application of EU rules in some members.

From a historical standpoint, the approach based on domestic politics is particularly persuasive in depicting the relationship between the evolution of monetary cooperation, on the one side, and two prototypical examples of domestic politics, on the other side. The first case is the decisive role of Franco-German relations and the two failed UK membership applications in the 1960s. It also explains the Gaullist inter-governmental position on European integration and the subsequent "Empty Chair Crisis" with France boycotting European institutions in 1965, de facto paralyzing any decisional process and any further attempt to push for a more federal Europe.

While it is correct to observe that very influential domestic actors usually have the last say in the states' decisions and preferences (including those related to the EU and EMU), taken alone, this approach is limited because it ignores the pressures coming from the EU. Reactions at state level (whether toward or against domestic reforming to cope with EU pressures) represent only one aspect of the two-level game between the EU and its members. To ignore or dismiss the EU level is a serious limit because the relationship between the EU and its members cannot be dismissed as a patchwork of domestic preferences.

Concerning the New Member States (NMS) that entered into the EU in 2004 and 2007, several new Central and Eastern members have abandoned their entry dates for adopting the Euro. More precisely, in 2004, with the entrance into the EU of ten new members ( 8 from Central and Eastern Europe), negotiations between the domestic and EU levels aimed at postponing their entrance into the Eurozone took place. In effect, despite the fact that adoption of the Euro was mandatory and the possibility to "opt out" was precluded, 
of the new ten members, only Slovenia adopted the Euro in 2007, followed by small members Malta and Cyprus in 2008, Slovakia in 2009, and Estonia in 2011. The absence of bigger economies such as Poland, the Czech Republic (mainly due to euroskepticism in public opinion), and Hungary in the Euroclub confirms that convergence and downloading Europeanization are far from being completely accomplished. Romania and Bulgaria, new members from 2007 but economically laggard, are even expected to convert to the Euro without a definite timetable.

More recently, the Maastricht and the Lisbon Treaties have been very precise on defining the functioning of monetary and economic union and members' obligations to cope with it. These treaties foresee the euro area as characterized by stability-oriented macroeconomic policies needed for the proper functioning of a single currency. From this standpoint, because of this legal framework, little room is granted for domestic politics and government decisions. However, both treaties leave room for lack of enforcement in the case a country should delay its entry into the Eurozone, and do not foresee any timetable for participation for each individual member since it is subordinated to the substantive requirements of participation. This could be seen as a paradoxical catch-22 situation because an indefinite schedule, due to the achievement of economic targets, is a political opportunity for members to search for delays, even if the fulfillment of economic criteria depends on political willingness or reluctance to achieve them.

While this is confirming the general assumption that EMU is a politically-driven process, it also shows that supranational institutions have had relatively weak capabilities (or willingness) to enforce their prerogatives but is still an evidence of the two-level game, especially if enforcement of rules should come to reality in future, as the solutions enacted 
since 2010 to tackle the financial crisis in Europe seem to suggest. Finally, the current economic crisis with the necessity to provide assistance to Greece, a laggard country that joined the euro in 2001 amongst various issues (cheating on the data, high deficit, and chronic tax evasion), is surely discouraging EU institutions from searching for adventurous pressures to push New Member States (NMS) to enter the eurozone. This means that since the Maastricht Treaty members' governments are not the only players having their say in EMU.

Another critique to the absolute predominance assessed to domestic politics is provided by various authors when observing that events external to EEC/EU and challenges to EMU coming from the international system constituted a main factor to seek further monetary integration. For Tsoukalis (1977) the breakdown of the Bretton Woods system in the late 1960s paved the way for the Werner Report, intended as a preparatory stage of EMU. Hence, Tsoukalis (1977) believed that the state-centric paradigm highlighted the importance of external factors, defined as the interrelation of domestic interests played outside the EEC, affecting the evolution of EMU. The merit of taking into account these factors is important because it explains why integration could progress or not as a result of international pressures. This analysis provides evidence showing that external shocks have been working as a trigger to promote more integration, rather than disintegration, in a way that I define federal. 


\subsection{Mixed paradigms}

\subsubsection{Europeanization}

This concept started emerging in the 1990s, first as a supranational approach, but later it has been redefined in a way that could be classified as an integrated approach, mixing supranational and domestic foci mutually hybridizing themselves. This approach was mainly inspired by constructivism (Wendt 1999), when arguing that the EU was a regime with its own "exceptional" nature, since it is a specific outcome of a given set of norms, beliefs, perceptions and attitudes inter-subjectively shared by its member states. For Europeanization theorists, the EU is sui generis artifact, unlike anything seen before in history. It is not a classic nation-state, nor is it just another intergovernmental organization. It is a supra-national body which needs its own theories to be explained.

Olsen (2002) provides a broad definition of Europeanization, highlighting five major features: (a) changes of EU external boundaries, (b) the development of institutions and governance at the EU level, (c) the penetration of the EU within members and local administrations, (d) the export of EU political organization and governance beyond the European territory, (e) the political project oriented to unify Europe. This typology captures bottom-up Europeanization (especially b), top-down Europeanization (especially c) and horizontal Europeanization (especially a and d). Taken together as a syncretic approach, these various definitions of Europeanization persuasively depict a logical and dialectic but not necessarily consequential process similar to federalism in which member-states first integrate themselves 
into the EU, and secondly adapt domestically to the EU inputs and possibly, if needed, show the willingness to change the EU functioning with a new bottom-up stream.

The supranational side or "Downloading" Europeanization means "to play the EU game". In the growing literature on this theory, the EU is assumed to be an autonomous actor, able to shape policies, polities and politics of its member-states, with a top-down stream as a result of the growing empowerment accorded to the EU in order to operate actively in a number of communitarian policies. The supranational side, conventionally named "top-down" Europeanization, is populated by a constellation of definitions. Featherstone and Radaelli (2003:7) define downloading Europeanization as the "domestic adaptation to the pressures emanating directly or indirectly from EU membership". Similarly, Cowles et al. (2001) address their attention to how and under what circumstances Europeanization shapes a variety of domestic structures in a number of members, given the emergence and the expansion of distinct structures of governance at the EU level. Further, Radaelli (2003) proposes a taxonomy for both theoretical and empirical purposes, underlying the differences among Europeanization, convergence, harmonization, and political integration. Bulmer and Radaelli (2004:4) define Europeanization as a process consisting of (i) construction, (ii) diffusion, and (iii) institutionalization of a plethora of formal and informal rules, procedures, policy paradigms, styles, ways of doing things, and shared belief and norms which are first consolidated at the EU level and then incorporated in the domestic environment. Cowles et al. (2001) argue that, whether or not a country addresses its institutional structure to Europe depends on the presence or absence of mediating factors. They posit five mediating factors: multiple veto points in the domestic structure, facilitating formal institutions, a country's organizational and policymaking cultures, the differential empowerment of domestic factors, and learning. Particularly successful 
has been the "goodness of fit" approach proposed by Risse, Cowles and Caporaso (2000), a situation that occurs when there is homogeneity between the domestic institutional framework and the European one, thus facilitating the implementation of EU directives.

Recently, the top-down stream of Europeanization has been considerably refined with an emerging attention on "bottom-up" Europeanization, which has been defined by Risse et al (2001:3) as "the emergence and development at the European level of distinct structures of governance, that is, of political, legal and social institutions associated with the problem solving that formalize interactions among the actors, and of policy networks specializing in the creation of authoritative European Rules”. Börzel (2002:203-206) recognizes three different attitudes of member states concerning bottom-up Europeanization. Pace-setting means that members actively push policies at the European level, reflecting minimal implementation costs once incorporated within existing arrangements. To the contrary, foot-draggers block or delay costly policies in order to prevent them altogether, or to achieve at least some compensation for high implementation costs. Finally, fence-setters mix both approaches, taking a position depending on the issue involved, as noted also by Falkner et al (2005).

Clearly, EMU can be inscribed as a case of Europeanization of public policy. In the case of monetary union, European integration was pursued with the inter-governmental bargain and, effectively managed by a supranational method by the European institutions. As noted by Major (2005), the dynamic of Europeanization (especially the "top down") applies more successfully to the policy comprised in the communitarianized first pillar. In the case of EMU, being one of the few policies on which the EU has exclusive competence, Europeanization seems to fit quite well. EMU is characterized by a gradual domestic adaptation before the entrance into the Eurozone to fulfill the criteria, but later, once in the club, members are legally subjected to strictly adapt to 
EU policy. In various studies, Dyson (2000a, 2000b, 2002, 2008) extensively underlined the fit of Europeanization as applied to EMU. For Dyson, the EMU can be understood as a process of Europeanization, with the Eurozone not only as a set of institutions that political actors manipulate, but also the arena within which the actors and their strategies are constructed. Dyson examines how EMU mechanisms affect political discourse, identities, structures, and public policies in EU members by analyzing the role of domestic policy-makers and institutions in framing domestic reactions. The main conclusion is that the EMU mostly affects the speed of domestic policy changes and reinforces the pressures for policy convergence, even though domestic institutional arrangements and changes in policy processes still show a great deal of variation. Featherstone (1999) argues that all the steps towards the EMU have been characterized by a political legitimization but for him the situation is complicated by the necessity of double levels of legitimization by different layers (the member-state and European ones) and by various actors (citizens, technocracies, and elites).

However, Europeanization applied to the EMU shows some limits. When "downloading" Europeanization is successful, EU policies enter into the domestic realm of its member-states. However, in the monetary union, as noted previously, the crucial logic of top-down Europeanization appears to be fragmented since responses from members have been differentiated (especially concerning the opportunity to adopt the euro or not), thus challenging the supposedly "all-embracing" explanatory leverage of Europeanization. This empirical complexity representing a threat to real convergence towards monetary union (as officially stated in the EMU Treaty), has significant repercussions on the explanatory power of the theory itself, which ultimately appears to be limited. In this regard, Dyson (2007a, 2007b) observes that the delay of the Euro adoption in Eastern and Central Europe limits the explanatory leverage of 
Europeanization. In fact, governments of New Member States have evolved political strategies to circumvent, even if temporarily, the required convergence towards euro adoption.

That is why terms such as differential Europeanization (Héritier and Knill 2001), paradoxical and clustered Europeanization (Dyson 2007a, 2007b), were elaborated to address this uneven impact of EU policy making on national environments, ultimately diluting the significance of the original theorization. For Dyson, Europeanization is differentiated because of different domestic responses because for new members, the EU is persuasive before their entrance, but they adopt elusive strategies once they get in. Furthermore, clustered convergence means that in the EMU, convergence in the future could be visible only in groups of countries, such as the Baltic States.

\subsubsection{Multi-Level Governance (MLG)}

Another theoretical apparatus that can be evoked to explain the evolution of the EMU is Multi-Level Governance (MLG) which originated from studies on European integration. Since the 1990s, the EU government has been defined as increasingly multileveled and interdependent. Principally, in the EU, the concept of "multi-level" has been used to denote the presence of various institutions that affect public policy in the EU member countries, while "governance" refers to the role played by non-state actors. In such an environment, MLG is defined as the intertwined policy formation processes at four levels: (1) the sub-state (the micro-regions within the states); (2) the domestic (the various member-states); (3) the supranational (the EU institutions); (4) non-state level, such as local, domestic and international Non-Governmental Organizations (NGOs). In line with MLG theory and practice, states are required to play the role of co-policymakers and/or policy implementers. On the other hand, the EU is supposed to be 
able effectively to drive policymaking, especially in areas where it is exclusively competent. Moreover, micro-regions within the state are relatively free to search for representation at the EU level, in order to gain revenue and legitimization as political actors. MLG is continuously shaped by different dynamics. In this way, trends toward decentralization of agenda-setting and devolution work well when there is symbiosis between the various levels of governance, providing the development of collaborative patterns.

The concept of "governance" defines the existence of a network of public and private actors, as well as individual and collective ones acting in politics (Marks 1993; Hooghe and Marks 2001). MLG emphasizes the capability of non-state and non-governmental actors to make pressures in the political arena relatively free from the control of official institutions. A first implication of MLG is that it challenges more traditional approaches that used to keep a clear distinction between the official public apparatus of the government and what is nongovernmental, private. The second implication is that MLG raised new theoretical and normative questions about the power and authority of states.

MLG was first used in the early 1990s by Gary Marks (1993) to capture developments in the European integration after the Single European Act (SEA) in 1988. Drawing from the policy networks approach in domestic politics, Marks (1993:392-411) defined MLG as "a system of continuous negotiation among nested governments at several territorial tiers". He further noted that within MLG "supranational, national, regional, and local governments are enmeshed in territorially overarching policy networks". For Hooghe and Marks (2001), MLG does not imply that central governments are no longer important; rather it contends that central governments are no longer the only institutions that control decision-making. Fundamentally, Multi-Level Governance implies that the making of public decisions is dispersed across multiple territorial 
levels. Further, according to Marks and Hooghe, the core argument of MLG is that "governance must operate at multiple scales in order to capture the variations in the territorial reach of policy externalities". Hooghe and Marks (2003) proposed two types of MLG. The first takes place when authority is granted to a narrow number of non-overlapping jurisdictions at a limited number of levels. In this kind of MLG, relatively stable, the structure of governance tends to bundle authority in quite large institutions. Conversely, the second type of governance is comprised of numerous overlapping jurisdictions hence it is fluid and flexible.

Looking at the EU, Marks and Hooghe propose a model in which institutions, such as international, national, regional, and local authorities, perform general-purpose functions in a Multi-Level Governance system. These institutions perform several functions, including a number of policy responsibilities. This model, then, is concerned with power sharing among actors operating at a limited number of levels. Applying the concept of MLG to EU decision making, Marks (2003) notes that in MLG, sub-state actors are important in the EU, leading to three tiers of decision making - national, supra-state, and sub-state. Other studies have also outlined some benefits of MLG. Pollack and Majone (1997) argue that multiple jurisdictions can facilitate credible policy commitments, for Weingast (1995) allow for jurisdictional competition, and for Gray $(1997,1998)$ boost innovation and experimentation.

With reference to the EMU, MLG is strongly correlated to the relationship between the European and the domestic levels, with little importance accorded to sub-state actors like local communities. This is because, before the EMU, monetary policy was in the hands of domestic governments and regulated by independent agencies such as the central banks. In this system of competences, scarce room was accorded to the local actors, such as provinces, regions, or lands. 
Consequently, with the aim to develop a common monetary policy, the EMU defined a new system of competences in which territorial actors were not involved.

Literature on the EMU grasps MLG theory to various degrees. Loedel (1999:125-144) observes that everything around the monetary union might suggest a typical case of centralized policy, constituting a counterfactual against MLG. However, Loedel argues that the ECB seeks to carefully balance supranational, national, and even local interests in its policy-making decisions, thus denoting a MLG framework that can explain the role of non-state actors and organized interests such as private banks and industries. Snaith (2011) proposes to study the 'Eurosystem' responsible for governing monetary policy within the Eurozone, framing a constructivist approach that identifies several relevant indicators of multi-level statehood to determine that EMU architecture can be classified as MLG. For Snaith, an evidence of governance is that the recipients of new powers in the EMU institutional architecture are public bodies (such as the European Commission, Council and Parliament) and non-governmental bodies (such as the European Central Bank). The result is the development of a new typology of MLG, which Snaith deems more appropriate than two-level game theories such as federalism, for instance.

Banducci, Karp, and Loedel (2003) examine MLG measured as the propensity to hand over sovereignty of the national currency to the supranational level departing from citizens' support for the euro. They discovered that citizens take into account domestic economic performance when evaluating the suitability of a common currency. In addition, recent studies found cases in which public opinion (Allam and Goerres 2008) and the public perception of the currency as a national symbol (Kaelberer 2004) played a major role in defining domestic strategies and attitudes toward EMU. These investigations seems to contradict the prediction 
stated in the 1997 by the Hans Tietmeyer, former Bundesbank President and former ECB Governing Board Member, who argued that the Euro will be a denationalized and de-politicized currency (Tietmeyer 1997). Further, von Hagen and Waller (2000) and Arnold (2001) investigated the effects caused by a common monetary policy within the diversified sub-national layer, reaching opposing conclusions. For von Hagen and Waller (2000) regional differences makes European monetary policy difficult to deliver, while for Arnold (2001), the importance of cross-country differences in monetary issues (such as the effects of interest-rate, exchange-rate, and asset price) is overestimated, especially in big economies.

Coming to the description of its limits, MLG applied to the European Union stresses the concept of shared sovereignty between intertwined polity levels (local, domestic, and the EU) and policy actors (public institutions and NGOs), whereas generally in a federal system there is a balance of competences between two levels (Buonanno and Nugent 2013). From this standpoint, I argue that MLG can be seen as a broader view of federalism, as a general theory and as a specific approach utilized to explain the EU. This assumption makes sense since federal systems have been already extensively depicted as multi-layered systems. In this regard, McKay (2001) observes that once the EU was defined as a multi-level system by Hooghe and Marks (2001), it followed that it could be compared with federal systems. A similar consideration has been made by Börzel and and Risse (2000) and Nicolaidis and Howse (2001). Kelemen (2004) argued that MLG initially was developed to explain policy developments in the EU, which increasingly has been viewed as a federal or quasi-federal system. On a theoretical level, Piattoni (2010) is cautious about the adoption of MLG as a general concept with the purpose of covering the process of EU integration, since it can become eminently descriptive and not sufficiently explanatory. This occurs because, according to Piattoni (2010:105) MLG fails "to prove that 
policy dynamics accumulate and escalate into policy transformations". Despite these shortcomings, for Piattoni (2010) MLG is a theoretical approach that has been used to explain political mobilization, policy-making and polity structuring. In chapter 6 I will adopt this approach to provide my definition of federalism and test it on EMU.

\subsection{Conclusion: Why Mixed Paradigms Work Better}

This chapter was dedicated to the presentation of the general assumptions of five mainstream integration theories and their recent permutations, their specific application to explain the EMU, and their major limits when applied to EMU. Building on this overview, in the conclusion of this chapter I discuss why mixed theories provide a better understanding of EMU than state-centric and supranational ones.

In the following table I test whether each paradigm has the leverage to explain the three features of EMU (polity, policy and politics) embedded in the supranational and the domestic levels across four different historical stages. As such, the first column on the left is based on the categorization I have made between state-centric, supranational and mixed theories. Furthermore, the table is built on two main indicators that will be the milestone of my theorization of federalism in the next chapter. The first indicator comprises the three features of EMU (polity, policy and politics) that I am investigating. The second indicator shows the two levels (the EEC/EU and its member-states) where polity, policy and politics apply. Finally, the table includes the historic evolution of EMU divided in four stages, as introduced in Chapter 4. 


\begin{tabular}{|c|c|c|c|}
\hline Paradigms & $\begin{array}{c}\text { EMU } \\
\text { Features }\end{array}$ & $\begin{array}{l}\text { Supranational and } \\
\text { Domestic Levels }\end{array}$ & $\begin{array}{c}\text { EMU - Historic Evolution } \\
\text { (1950s-up to date) }\end{array}$ \\
\hline \multirow{6}{*}{$\begin{array}{c}\text { State-Centric } \\
\text { (Intergovernmentalism, } \\
\text { Domestic Politics) }\end{array}$} & \multirow{2}{*}{ Polity } & ECC/EU & \\
\hline & & Members & $\sqrt{ }$ \\
\hline & \multirow{2}{*}{ Policy } & EEC/EU & \\
\hline & & Members & $\sqrt{ }$ \\
\hline & \multirow{2}{*}{ Politics } & EEC/EU & \\
\hline & & Members & $\sqrt{ }$ \\
\hline \multirow{6}{*}{$\begin{array}{c}\text { Mixed } \\
\text { Federalism } \\
\text { Europeanization } \\
\text { MLG }\end{array}$} & \multirow{2}{*}{ Polity } & EEC/EU & $\sqrt{ }$ \\
\hline & & Members & $\sqrt{ }$ \\
\hline & \multirow{2}{*}{ Policy } & EEC/EU & $\sqrt{ }$ \\
\hline & & Members & $\sqrt{ }$ \\
\hline & \multirow{2}{*}{ Politics } & EEC/EU & $\sqrt{ }$ \\
\hline & & Members & $\sqrt{ }$ \\
\hline \multirow{6}{*}{$\begin{array}{c}\text { Supranational } \\
\text { (Neo-functionalism) }\end{array}$} & \multirow{2}{*}{ Polity } & EEC/EU & $\sqrt{ }$ \\
\hline & & Members & \\
\hline & \multirow{2}{*}{ Policy } & EEC/EU & $\sqrt{ }$ \\
\hline & & Members & \\
\hline & \multirow{2}{*}{ Politics } & EEC/EU & $\sqrt{ }$ \\
\hline & & Members & \\
\hline
\end{tabular}

Tab. 4 - Explanatory leverage of three paradigms on EMU polity, policy and politics (at supranational and domestic levels) in historical perspective.

The second step of this conceptual framework consists of deriving from each theory the causal patterns that should be observed if the theory is valid. In the case of EMU, for state-centric approaches the prediction (area marked with a tick) is that ECC/EU members should retain a high degree of sovereignty over policies, retain power and prerogatives as institutions and play an almost exclusive role in political negotiations. For supranational approaches the opposite is true, since the expectation is that EMU institutions are prominent over governments, they establish and administer policies, and supranational technocracy should overcome domestic politics. Finally, mixed accounts take into consideration both approaches, envisioning in EMU a complex interplay and a balance of power between 
domestic and supranational levels from polity, policy and political standpoints. In the following chapter, using the same conceptual framework of table 4, I will develop in a more detailed manner the portion of the table describing the explanatory leverage of mixed theories (highlighted with a grey background), with specific reference to federalism.

Looking at the mixed approaches discussed in this chapter, I do not challenge the power of Europeanization and Multi-Level Governance in providing a parsimonious, structural, and multilayered explanation able to elucidate the overall EMU evolution, as shown in table 4. However, it must be noted that Europeanization and MLG have the great advantage of having been elaborated relatively recently, in the 1990s after the Maastricht Treaty, which formally outlined the official stages of pursuing a real monetary union. This means that concerning EMU they were able to encapsulate the "inevitability" of the monetary union already en route. Vis-à-vis all these approaches, I believe that federalism is a relatively traditional theory which is still able to maintain his explanatory leverage on EMU.

The need for a mixed approach has been legitimized by the recent permutations on integration theories, not necessarily applied to EMU. Given the real evolution of European integration, some scholars argued for the need of a theoretical compromise between approaches underlining the exclusive role of the state and those envisioning a decisive role of the EU, in order to not to lose their explanatory leverage. As it should have emerged by the literature review, a path toward the "supranationalization" of intergovernmentalism and "intergovernmentalization" of supranational approaches such as neo-functionalism can be detected. As a consequence, Wessels (1997) advocated the eclectic combination of different theories - the so called "fusion approach" - to provide a broader picture of the phenomenon under scrutiny. In line with this position, other authors such as Sandholtz and Stone Sweet 
(1998) observed that clear cut dichotomies among theories should be lifted. For them, in any case, the EU cannot be seen as single regime with a predominant theoretical account, but rather as a series of regimes for different policy areas. That is why they agree on the opportunity to merge theories, despite apparently conflicting with each other, since intergovernmental and supranational tendencies are both represented in the real world of European politics, as I already highlighted earlier in the historical chapter. Similarly, Wiener and Diez (2004:1-21) argued that integration theory is a mosaic since these approaches are sometimes complementary.

Verdun (2002) made this appraisal with specific reference to the EMU, when concluding that "[intergovernmental and neo-functional] theories need to be merged in order for us to obtain a better picture of the actors involved in the European integration process" (Verdun 2002:15). Based on the case of the EMU, Verdun observed that by taking together the two theories - supranational (neofunctionalist) and state centric (intergovernmental) -, the whole picture of the EMU can be portrayed. Also, departing from a game theory standpoint, Wolf (2002) concludes that the amalgamation of the two approaches will result in a better understanding of the monetary union. 


\section{Explaining Economic and Monetary Union Using Federalism}

\subsection{Conceptualizing Federalism and Testing it to EMU Policy, Policy and Politics}

The first and most important aim of this dissertation is to analyze "how" EMU has been politically developed, how policies have been implemented, and how the polity has changed over the decades. In this regard, I assume that federalism is the mechanism through which EMU has been orchestrated in the past and operates now (especially the monetary union) and will be crafted in the future (especially the economic union, still on its way). Of course, federalism is a multidimensional concept that needs to be carefully defined in order to achieve some leverage in explaining the process of EU integration, and more specifically EMU. In more detail, I adopt the concept of federalization, horizontal federalism and vertical federalism, through which I identify three hypotheses:

- H1: the incremental writing of the "rules of the game" has been made possible by the European Council through horizontal federalism ("the method").

- H2: horizontal federalism has almost always strengthened EC/EU institutions ("the outcome") and targeted the vertical centralization of economic and monetary affairs.

- H3: horizontal and vertical federalism elicited an incremental and steady federalization of EMU ("the process") that is lasting from the 1950s to nowadays. 
With specific reference to EMU, I will use the longitudinal concept of federalization, "emerging federalism" (Macmahon 1962) and the "federal integration approach" as suggested by Buonanno and Nugent (2013). These concepts share the attribute of using time as central vector of incremental change, shedding light on the causes of the existence of EMU. In this regard, the progressive centralization of economic policies can be labeled as "federalization in progress" defined as the achievement of the Customs Union at the end of the 1960s, the Single Market in 1992, and the Common Currency in 1999, followed by the current discussion on the "economic leftovers" bringing about a further move towards a possible fiscal, banking and debt union. This kind of stage-based integration model resembles a form of Economic Federalism, as suggested by Balassa (1961) and recently reasserted by Crowley (2006) on EMU. Building on the Balassa sequence of economic integration, Crowley argued that the later integrationist step could feature an economic, political or fiscal union, depending on whether EMU can be considered an Optimal Currency area or not.

Horizontal federalism (Zimmerman 2011) focuses on the relationships between constituent units with minimal involvement at the central level. In EMU, the European Council and to a lesser degree the EcoFin can be interpreted as the institutions performing horizontal federalism that is the method through which they have set the "rules of the game" at any given time. In this regard, the European Council and EcoFin have been almost always seeking supranational solutions delegating EU institutions to solve EMU issues, in line with the supranational nature of the challenges. As a result, domestic sovereignty has been progressively eroded by the setting of a common supranational framework despite the sometimes obstinate - resistance of EC/EU members who unsuccessfully wanted to retain a 
great deal of power in economic and monetary affairs. As such, I believe that in EMU the method of horizontal federalism targeting policy centralization as an outcome corresponds to the federalization of economic and monetary issues.

Vertical federalism denotes the allocation of power between the central government and the constituent units. Whereas this allocation of power can occur in various ways, generally in a federal system there is a balance of competences between the two levels (Buonanno and Nugent 2013). In EMU, the establishment of a "vertical federal authority" (Persson and Tabellini 1996:979) is the outcome; the central level in charge of policy delivery in monetary affairs and oversight in macroeconomic issues of the constituent units has gone much beyond the mere horizontal pooling of sovereignty and limited delegation as stated by intergovernmentalists. However, the power of the constituent units in vertical federalism should not be dismissed, since they have control of the political direction of the EU through the Council; furthermore, the governments of EU members are in charge of implementing the macroeconomic provisions of EMU and fulfill EU membership criteria at the domestic level.

Taken together, horizontal and vertical federalism define a mixed paradigm where both EU (supranational) and members (constituent units) factors are dialectically taken into account in explaining EMU. Using the analogy of Janus, the two-faced god, institutionally EMU is a federation featuring a complex interplay and a balance of power between the domestic and supranational sides. I believe that federalism is a useful descriptor of EMU, featuring a decision-making process that involves the simultaneous mobilization of domestic and supranational authorities. These different jurisdictional levels interact throughout vertical and horizontal fluxes, clearly undermining the conventional European state-centric governmental 
practices. My conceptualization follows the direction undertaken by theorists of Europeanization. In fact, the definition of Europeanization as well is comprised of several sub-definitions (i.e. bottom-up, top-down and horizontal), which taken together give to this approach a certain degree of analytical persuasiveness and explanatory leverage.

An important implication following my conceptualization is that this dissertation conceives federalism as a multilayered structure. Dyson (1994) was the first one to identify structural sources in both the internal dynamics of EC/EU and the international context affecting the evolution of monetary union in Europe. His argument is that the process establishing a fullfledged monetary union in Europe is "composed of a distinct set of interdependent bargaining relations and institutional rules of the game, embedded in a framework of structures that they have a limited, and fluctuating, capacity to influence" (Dyson 1994:x). Encapsulating Dyson's assumption in a federalist framework, the problem becomes investigating how domestic and supranational factors in a federalist structure played a role in defining the rules of the EMU game (anytime from the 1950s), in playing the EMU game (since 1999), and renegotiating the rules of EMU since 2008 to face the economic crisis.

Moving from the level of conceptualization to operationalization, I test the federalist approach as a polity - or a multilevel structure or framework - in which EU and domestic initiatives - broadly defined as politics - determine the EMU policy. This is a prima facie test of federalism. I define polity as the legal venue where powers, authority and sovereignty are allocated. This concept outlines the balance of power and the division of competences between the EU's and members' institutions governing EMU. Politics are the arenas where the actors (mainly the EEC/EU and its members) bargain to gain authority or power over EMU or negotiate 
to find acceptable compromises that satisfy all parts. Policy is how the monetary and economic policy is actually delivered.

My innovative application of federalism to EMU politics, policy and polity departs by Simona Piattoni's (2010) book titled The Theory of Multi-level Governance: Conceptual, Empirical, and Normative Challenges. Piattoni highlighted the significance of theorizing and testing multi-level governance simultaneously in politics (defined as political mobilization), policy (authoritative decision making) and polity (state restructuring) terms. The author applied this multidimensional analytical space to three levels of analysis, identified according the continuums center-periphery, state-society and domestic-international dynamics. Piattoni examined three policy areas (cohesion, environment, and higher education) in two member-states (the UK and Germany) to demonstrate the efficacy of MLG as a theoretical and empirical concept. In conclusion, Piattoni (2010: 246) argued that "multi-level governance arrangements, characterized as a loosely coupled structure, are able to secure coordination among public and private actors at different territorial and jurisdictional levels, and reduce the risk of falling into the 'joint decision trap' due to their flexibly structured nature”.

Finally table 5 compares the hypothesis I have formulated on EMU from my conceptualization of federalism with the predictions provided by other mainstream theories of European integration. As I said already above, federalism (and other mixed paradigms such as MLG and Europeanization) from a polity perspective envision a balance of powers between supranational (i.e. the ECB and the European Commission) and domestic institutions (i.e the European Council, EcoFin and domestic governments). From a policy perspective, these theories predict a vertical delegation of power that empower the centralized government to deliver EMU policy and allows the constituent units to keep the control of the macro targets of EMU and the 
domestic implementation of EMU policy. Finally, from a political perspective, not only domestic politics matter but also the role of the European institutions that acting as political entrepreneurs constantly push for more integration.

\begin{tabular}{|c|c|c|c|}
\hline Paradigms & Supranational & State-Centric & Mixed \\
\hline Theories & Neo-Functionalism & $\begin{array}{l}\text { Intergovernmentalism, } \\
\text { Domestic Politics }\end{array}$ & $\begin{array}{l}\text { Federalism, MLG, } \\
\text { Europeanization }\end{array}$ \\
\hline $\begin{array}{l}\text { EMU } \\
\text { Polity }\end{array}$ & ECB, Commission & $\begin{array}{c}\text { European Council, } \\
\text { EcoFin } \\
+ \\
\text { Domestic governments } \\
\end{array}$ & $\begin{array}{c}\text { ECB, Commission } \\
+ \\
\text { European Council, EcoFin } \\
\text { and domestic governments }\end{array}$ \\
\hline $\begin{array}{l}\text { EMU } \\
\text { Policy }\end{array}$ & $\begin{array}{l}\text { Spillover, } \\
\text { technocracy }\end{array}$ & Horizontal pooling & Vertical delegation \\
\hline $\begin{array}{l}\text { EMU } \\
\text { Politics }\end{array}$ & Irrelevant & Domestic preferences & $\begin{array}{c}\text { EU political } \\
\text { entrepreneurship + } \\
\text { Domestic preferences }\end{array}$ \\
\hline
\end{tabular}

Tab. 5 - Predictions of European integration theories on EMU polity, policy and politics.

Conversely, state-centric approaches emphasize the predominant role of domestic factors, broadly defined. From a polity perspective, in EMU the most important actors are the European Council, the EcoFin and domestic governments that predominate over supranational institutions. As such, the only option for EMU is the horizontal pooling of sovereignly among domestic governments, loose intergovernmental cooperation, and limited centralization to the central level. Theorists of liberal intergovernmentalism developed in the 1990s had to admit that traditional intergovernmentalism became limited in portraying the supranationalization of EMU. As such, for LI institutional delegation happens only when inter-state commitments achieve a level of consolidated credibility to the point of developing supranational institutions. Finally, state- 
centric approaches clearly dismiss the importance of any political pressure coming from supranational institutions, since the direction of EMU is decided by domestic politics and preferences, especially those from the most powerful EU members such as France and Germany.

Finally, neo-functionalism emphasizes the pivotal role of supranational institutions and elites in the process of promoting incremental integration in EMU. It means that for classic neofunctionalists each EU member necessarily achieves policy maximization at the supranational level. More recently, however, scholars have expanded their analyses including societal actors and national governments as well. Policy integration takes place throughout a deterministic functional spillover across economic sectors, following the cumulative logic according to which integration in one policy necessarily leads to integration in a neighboring policy. As such, the delivery of EMU policy is technocratic and the nature of EMU integration is relatively free from political interference. More recently, however, Tranholm-Mikkelsen (1991) elaborated the idea of political spillover, an outcome of a deliberated political process when domestic actors realize that supranational cooperation could be the best approach to solve domestic problems.

The assessment of my conceptualization of federalism on polity, policy and politics of EMU is the topic of the rest of the chapter. Following the four-stage periodization I already identified in the empirical chapter, the first period featuring the onset of economic integration from 1950 s to 1968 is tested in depth in the following section. The second stage from 1969 to 1998, where the federalization of monetary issues took place, is taken into consideration in section 6.3. The third stage, featuring the accomplishment of the monetary union, is tested in section 6.4. Finally, the period running from 2008 up to date, featuring federalist solutions put into practice to tackle the ongoing EMU crisis and de facto envisaging a fully-fledged economic union is developed in section 6.5. 


\subsection{The Incremental Federalization of Economic Affairs (1950s-1968)}

This section refers to the onset of economic integration that featured the initial federalization of economic affairs. As I have already discussed in chapter 4, early pioneering discussions concerning the idea of integrating Western European economies took place in the 1950s and the 1960s, promoted by several federalist supporters in Europe, such as Altiero Spinelli and Jean Monnet, and prominent politicians such as Paul-Henry Spaak, Konrad Adenauer, Robert Schuman and Alcide De Gasperi (Italian Prime Minister 1945-53). As well, an important factor was the intervention of the United States in European affairs after WWII.

Why had some moderate progress in economic integration been possible in a context indisputably controlled by EEC members' polity, policy and politics? Why the European Economic Community was able to achieve a customs union and a Balance of payments program despite the opposition of intergovernmentalist politicians such as Charles De Gaulle? As I have shown in the historic chapter, the first reason leading to supranational coordination in economic issues was a cooperative response to avoid the atrocities of World War II and to create a liberal bloc during the Cold War.

How was this supranational coordination crafted? Table 6 synthetizes my federalist structure concerning the onset of economic integration from 1950s to 1968, which I believe represents the beginning of the federalization process, especially in economic affairs. This framework envisions a complex interplay and a balance of power between domestic and supranational on three EMU attributes - polity, policy and politics. This interplays being made possible by the adoption of several subsets provided by the federalist theory - horizontal federalism is the method, vertical federalism the outcome and federalization is the process. This 
table will be repeated in the following sections exploring the relevant developments of the period under consideration.

\begin{tabular}{|c|c|c|}
\hline $\begin{array}{l}\text { EMU } \\
\text { Attributes }\end{array}$ & $\begin{array}{l}\text { Supranational } \\
\text { and Domestic } \\
\quad \text { Levels }\end{array}$ & $\begin{array}{l}\text { Onset of Economic Integration } \\
\qquad(1950 \mathrm{~s}-1968)\end{array}$ \\
\hline \multirow{2}{*}{ Polity } & ECC/EC/EU & $\begin{array}{l}\text { Treaty of Rome, creation of the High Authority/Commission; five } \\
\text { economic-related Committees and the Assembly/Parliament, mainly } \\
\text { with advisory and technocratic functions on domestic macroeconomic } \\
\text { and monetary policies. }\end{array}$ \\
\hline & Members & $\begin{array}{l}\text { Council of Ministers leading the EEC decisional process; governments' } \\
\text { sovereignty on macroeconomics and monetary policies. }\end{array}$ \\
\hline \multirow{2}{*}{ Policy } & ECC/EC/EU & $\begin{array}{l}\text { European Economic Community, Customs union, European Payments } \\
\text { Union, European Monetary Agreement. }\end{array}$ \\
\hline & Members & $\begin{array}{l}\text { Removed trade restrictions; formally committed but actually elusive on } \\
\text { macroeconomic and monetary coordination. }\end{array}$ \\
\hline \multirow{2}{*}{ Politics } & ECC/EC/EU & $\begin{array}{l}\text { The High Authority/Commission interpreted extensively the Treaty of } \\
\text { Rome, pushed for more macroeconomic coordination, and proposed } \\
\text { program towards common market and monetary union. }\end{array}$ \\
\hline & Members & $\begin{array}{l}\text { Narrow interpretation of the Treaty of Rome, diluted coordination into } \\
\text { consultation, reluctant to pool sovereignty but gradually granted } \\
\text { concessions to the EEC in economic realm. }\end{array}$ \\
\hline \multicolumn{2}{|c|}{$\begin{array}{l}\text { Federalism Applied } \\
\text { to EMU Integration }\end{array}$} & Federalization of economic affairs \\
\hline
\end{tabular}

Table 6 - Explaining EMU using a federalist structure (1950s-1968).

During the early stage of European integration (1950s-1968), the polity was dominated by domestic sovereignty that made the European Economic Community (EEC) look like a loose and unambitious international organization. The intergovernmental Council 
of Ministers representing six members' interests was clearly in charge of the whole EEC decisional process. In fact, the Council had to decide mainly by unanimity on High Authority's bills and set ECSC goals to be achieved by the High Authority. Unanimity was essential to guarantee that all the contracting parties would have their positions and interests adequately taken into account before deciding for policy centralization. As such, the decision-making process was complex and inflexible, eminently intergovernmental. On the relative lack of power of EEC institutions in the 1960s, there are few doubts that the EC started as a loose and unambitious international organization in the 1950s. In addition, Burgess (2000:262) observed that "in establishing the European Economic Community (ECC) in 1957, the basic structure resembles more an economic confederation than anything else".

On the other side, the supranational High Authority/Commission, a quasi-executive body representing the ECSC interests, was empowered to be the sole initiator of legislation and to oversee the application of the Treaty of Rome provisions. The Commission had the formal power of investigating the position of Treaty's infringers and, acting as a technocratic body, of recommending measures to be implemented. According to Walter Hallstein, first president of the EEC Commission, the High Authority was supposed to work as a federal agency independent from domestic interests (Tsoukalis 1977). It is also true that in the 1960s the Commission had many more responsibilities and power to enact commercial and competition policies than it had in macroeconomic and monetary issues (Maes 2006). However, Tsoukalis (1977) observed that for many politicians orchestrating the early economic integration, the new institutions were "the embryos of fully-fledged federal institutions" (Tsoukalis 1977:21). Other institutions than the Commission, namely Short- 
Term and Medium-Term Economic Policy Committees, the Monetary Committee, the Committee of the Governors of Central Banks and the Common Assembly/European Parliament, were set up mainly intended to work as advisory bodies but with the passing of the time they were empowered to become much more relevant than they were at the beginning.

From a policy perspective, the governments of the six members had firm control of their respective economic and monetary policies, leaving room for a limited "pooling of sovereignty", and mere consultations on macroeconomic policy. However, they largely ignored the few monetary provisions they had already agreed upon. This is because the loose supranational framework allowed governments to formally commit themselves to EEC rules without feeling bound by any decision taken by the Council of Ministers. They sometimes invoked the escape clauses when experiencing economic troubles, but more frequently because they knew that the EEC institutions were not empowered to grant sanctions. This being said, they succeeded in the removal of trade restrictions and barriers in order to achieve a customs union at the end of the 1960s. Furthermore, the European Payments Union (EPU) and the European Monetary Agreement (EMA) became effective in the 1960s, showing some progress made by domestic governments towards the federalization of economic and monetary affairs.

In this framework unquestionably controlled by EEC members but de facto quite elusive in pursuing the legal obligations and the integration objectives they formally had committed to, the Treaty of Rome represented the embryonic act which initiated the long, political and legal path towards am "ever closer union among the peoples of Europe" (Treaty establishing the European Community 1957: preamble). The first accomplishment of the 
Treaty was the achievement of the customs union at the end of the 1960s. In terms of positive integration, the Treaty clearly dictated that members should have regarded their macroeconomic policies as a matter of common concern and thus seek coordination. Furthermore, the coordination in the monetary field was clearly envisioned in the Treaty. As such, EEC members should have limited the manipulation of the exchange rate of their currencies as an instrument to control internal economic stability since an excessive flotation was considered detrimental for the achievement of a customs union or common market. In monetary affairs, the only two achievements were represented by the European Payments Union and the European Monetary Agreement. They introduced the idea of solidarity for troubled members in the form of ad hoc mutual assistance, an idea which would be developed later in the 1970s and finalized with a permanent mechanism in 2013.

A call for the appropriateness of using the concept of federalization from the very beginning of monetary and economic integration comes from Pinder (1991) when arguing that Monnet's attention to policy integration and Spinelli's approach rooted in building federal institutions legitimized by a constitution were put into practice slowly but simultaneously. For example, in the 1960s the targeting of a customs union was accompanied by the creation of new institutions such as the High Authority/Commission legitimized by a legal treaty.

In terms of domestic politics, the sovereign conception of monetary policy from each EEC member was to consider the manipulation of the exchange rate regime as a governmental prerogative suited to the specific needs of their domestic economies; as a consequence, they were reluctant to give up sovereignty in monetary affairs, despite the fact that post WWII leaders were generally favorable to integration, but under certain conditions 
and limits. In this regard, the French President De Gaulle was the most reluctant to initiate negotiations aimed at delegating more powers to the EEC. Conversely, from an economic perspective, all the six members in the 1960s had a stable and progressive economic development, which gave them a common platform upon which to build a pan-European common market. This does not mean that the Council found unanimity easily since diverging domestic preferences were debated and needed to be compromised. In this regard, the most important conflicting vision occurred between monetarists coalesced with France under the assumption that monetary integration should precede economic integration and economists siding with Germany that argued that economic coordination should be followed by monetary integration later.

On the other side, looking at the political activity of EEC institutions, tensions erupted, bringing about a subsequent need to seek a compromise between a narrow interpretation of the Treaty of Rome by EEC governments as opposed to a broader interpretation by the High Authority/Commission, the Monetary Committee, and the Parliament. The Commission openly invoked fewer domestic interventions in economic issues by ECC governments and pressed onwards to a faster achievement of an economic, monetary, and political union. As such, for Maes (2006), since the 1960s the European Commission has ascended as an actor in the process of monetary integration. The activism of the Commission culminated with the Action Programme for the Second Stage of the EEC (1962), which was pushing towards the achievement of a full customs union, a common market, and a monetary union. 


\subsection{Towards a Single Currency: Federalization of Monetary Issues (1969-1998)}

Progress towards monetary unification became more tangible in the 1970s and culminated in 1999 with the creation of the euro. Taylor (1975), Crawford (1996: 338-365), Pinder (1998:142-

181), Burgess (2000), and McNamara (2003: 253-269), depicted the evolution of the EMU as a progressive process of federalization, highlighting that all the steps pre-Maastricht were eminently "confederal". This understanding of confederalism approximates horizontal federalism as a way to get federalization. Since the 1970s, supranational actors were established and had the legitimacy to act as political entrepreneurs and the authority to push for more integration; thus federalization became a two-level game. As a consequence, I believe that federalism can explain the rising power of EC/EEC/EU institutions face-to-face governments???? (polity), the competing pressures coming from both domestic governments and European institutions (politics), and the progressive federalization of economic and monetary policies. These developments are synthetized in table 7 (next page).

Why did further integration become feasible? The collapse of the Bretton Woods system of fixed exchange in 1971 and the oil crisis in 1972 caused high inflation, a rise in unemployment rates, a shortage of the oil supply, balance of payments deficits, and stagnant economies after years of economic boom. These monetary and economic shocks initially caused the failure of the Werner Plan (except for the Snake) which was designed on the basis of the Bretton Woods system, but in the long run members' governments realized the importance of concomitant policy obligations, ultimately enacting macroeconomic convergence and monetary stabilization better to face the challenges coming from the international system. From an international perspective, the attainment of the Single Market in 1992 can be seen as a direct response to the rising 
competitiveness of the Japanese economy in the 1980s. Furthermore, the achievement of a monetary union was a direct consequence of the end of the Cold War that caused fears in Europe towards a too powerful Germany after its unification. These tensions were resolved with the project of sharing a currency complementing the single market.

\begin{tabular}{|c|c|c|}
\hline $\begin{array}{c}\text { EMU } \\
\text { Attributes }\end{array}$ & $\begin{array}{l}\text { Supranational } \\
\text { and Domestic } \\
\text { Levels }\end{array}$ & $\begin{array}{l}\text { Towards a Single Currency } \\
\qquad(1969-1998)\end{array}$ \\
\hline \multirow{2}{*}{ Polity } & $\mathbf{E C C} / \mathbf{E C} / \mathbf{E U}$ & $\begin{array}{l}\text { In the 1970s some authority moved in ECC institutions and } \\
\text { advisory/technocratic functions enhanced; QMV extended; in } 1979 \text { first } \\
\text { direct election of the European Parliament which in the 1980s acquired } \\
\text { a legislative role; in the 1990s the Commission increased his } \\
\text { monitoring powers; in } 1999 \text { the European Central Bank established. }\end{array}$ \\
\hline & Members & $\begin{array}{l}\text { Creation of the European Council setting policy targets and macro- } \\
\text { directions in EMU; creation of the EcoFin, the main decision-making } \\
\text { body of EMU }\end{array}$ \\
\hline \multirow{2}{*}{ Policy } & $\mathbf{E C C} / \mathbf{E C} / \mathbf{E U}$ & $\begin{array}{l}\text { The Barre Report, the Werner Report, the Snake in a Tunnel, European } \\
\text { Monetary System, the Single European Act, the Delors Report and the } \\
\text { Maastricht Treaty, the Single Market; Economic and Monetary Union. }\end{array}$ \\
\hline & Members & $\begin{array}{l}\text { Still elusive in the } 1970 \text { s, enacted macroeconomic coordination in the } \\
1980 \text { s, fulfilled convergence criteria in the 1990s elusive on SGP } \\
\text { requirements after joining the euro. }\end{array}$ \\
\hline \multirow{2}{*}{ Politics } & $\mathbf{E C C} / \mathbf{E C} / \mathbf{E U}$ & $\begin{array}{l}\text { The Commission acted as a political entrepreneur for integration, role } \\
\text { of the president of the Commission enhanced. }\end{array}$ \\
\hline & Members & $\begin{array}{l}\text { End of Gaullist era, politicization of monetary issues, German-French } \\
\text { axis, politically accepted redistribution of sovereignty in the } 1970 \text { s, } \\
\text { targeting macroeconomic coordination in the } 1980 \text { s and convergence in } \\
\text { the } 1990 \text { s. }\end{array}$ \\
\hline \multicolumn{2}{|c|}{$\begin{array}{l}\text { Federalism Applied } \\
\text { to EMU Integration }\end{array}$} & Federalization of monetary issues (1970s) and economic affairs (1980s) \\
\hline
\end{tabular}

Tab. 7 - Explaining EMU using a federalist structure (1969-1998). 
From a domestic polity perspective, this supranational fervor was compensated by the creation of the European Council, a top level intergovernmental summit featuring the meeting of chief executives, formalized in the period between 1974 and 1988. The European Council was intended as a "directorate" from larger countries, and allowed domestic executives to get deeply involved in all the major decisions affecting European affairs. The power of horizontal federalism was further enhanced with the establishment of EcoFin, a configuration of the Council of Ministers composed of the ministers of economics and finance of the EU members. EcoFin was the main decision-making body of EMU, in charge of economic policy coordination and economic and monetary surveillance.

Simultaneously, the polity became increasingly supranational. In the 1970s domestic sovereignty started to shift, with some authority moved into the European institutions. The use of Qualified Majority Vote was extended in two occasions, a move towards supranationalism since QMV was aimed at avoiding stalemate in horizontal federalism. The political authority in charge of the EMCF was the Committee of Governors of Central Banks, which was required to work in agreement with the Council. In 1979 the first direct election of the European Parliament took place, which in the 1980s acquired a legislative role in the decision-making process that has grown even stronger. In the 1990s the Commission increased its monitoring powers. This process culminated in the establishment of the European Central Bank, which placed the former Committee of Governors as the Governing Council of the ECB.

In terms of domestic policy, the 1970s began with the same trend observed in the 1960s, members being reluctant to harmonize their macroeconomic and monetary policies. This elusiveness, which was perpetuated due to a loose Communitarian framework that had 
remained unchanged since the 1960s, was aggravated by the monetary and economic crisis erupting at the beginning of the 1970s that produced extremely uncoordinated responses among EEC members, mainly because of economic emergency. However, the increased economic interdependence of the EEC members and the awareness of the widespread instability when challenged by external shocks brought about a change of attitudes in early 1980s. Governments realized the importance of concomitant policy obligations, ultimately enacting macroeconomic convergence and monetary stabilization, as repeatedly suggested by the Commission over two decades. As such, currency realignments were decided by collective decision, national economies became more integrated by pursuing stabilityoriented policies, and common policy targets were finally driving domestic policy actions. In the 1990s, all members met the convergence criteria required to adopt the euro. However, as I will elucidate in the following section, most of them became more elusive when it came to fulfill the requirements of the Stability and Growth Pact after their entrance into the Eurozone.

As for supranational policy, progress was evident as shown by the sequencing of several crucial documents. The Barre Report recommended the same policy provisions already proposed in the past but introduced the idea of a European monetary identity. The ambitious goal of the Werner Plan would be the irreversible convertibility of EC currencies, the permanent locking of exchange rates and, possibly, a single currency. Due to the monetary and economic shocks erupting in early 1970s, the only implementation of the Werner Plan was the "Snake in the Tunnel" (1972-1979), established with the purpose of reducing the magnitude of intra-currency fluctuations. The European Monetary Co-operation Fund (1973) consisted of a pool of financial resources available for all members having 
financial difficulties. The European Monetary System (1979) was a system designed to reduce exchange rate variability and achieve monetary stability in Europe, since each domestic currency had a fixed rate against the European Currency Unit (ECU). The Single European Act (1986) was a legal amendment of the Treaty of Rome, significantly expanding the domains of economic integration. The Single Act that proclaimed a single market and a common currency as official goals of the EC and, as such, codified a number of major economic preconditions for fair competition and long-term stability within the internal market. This integrationist trajectory finally culminated in the Delors Report (1989) which was the blueprint for the Maastricht Treaty (1992), since it reiterated the unavoidable conditions for a monetary union and proposed a three-stage approach to seek EMU, ultimately achieved in 1999.

Politically, from the 1970s the European Commission as an independent political entrepreneur pushed for the process of European integration, being able to compete with the traditionally more powerful EcoFin, the newly formed European Council and members' governments. The three-stage approach introduced in the Barre Memorandum, even if unrealized at that time, would become the conventional planning method followed at the end of the 1960s by the Werner Report and later in the 1990s to achieve EMU. As well, the various EEC Committees dealing with monetary and economic affairs played a prominent role, advising politicians from a technocratic perspective and playing a major role in setting up the Werner Plan, which was released in a joint document ascribed to both the Council and the Commission. This openly reflected the fact that it represented a political compromise between the two institutions. 
At the end of the 1970s, the first generation of federalists was succeeded by later supporters that made the evolution towards the European Union possible. As such, the revival of advancing monetary integration came from the leaders of France and Germany, but was backed by the European Commission President Roy Jenkins, and by an agreement between the central bankers of the EEC members. The ascent of Jenkins as a political actor showed that political role and the prestige of the president of the Commission was enhanced, as reaffirmed ten years later when a new debate among European policymakers toward the opportunity of a monetary integration was ignited by the president of the Commission, Jacques Delors. In doing this, they were supported by an epistemic community of technocrats and civil servants supporting the idea of a federal Europe from ideological and philosophical perspectives.

Concerning domestic politics, the election of George Pompidou in 1969 reversed the position of France, traditionally hostile to any form of supranationalism under de Gaulle, and made it possible the rise of the Franco-German axis. In the 1970s monetary issues became highly politicized. After the Werner Report all members politically had to accept the idea that a redistribution of sovereignty would be inevitable should they want to engage in an economic and monetary union. With the creation of the EMS, EEC members realized that it was better to establish a parallel regional currency in which they had some decisional power rather than pegging their currencies to those of foreign countries. In the first half of the 1980s, governments finally understood the political viability of enacting the requirements coming with EEC membership. The negotiations occurred during the second half of the 1980s concerning the feasibility of a common currency featured supportive, reluctant, and ambiguous members' positions which were mainly resolved using political compensation 
such as side payments, package deals, or issue linkage. Convergence in economic and monetary issues became a political necessity and was successfully achieved when the Maastricht Treaty delineated the single currency as a goal. Obviously, behind any political decision to promote centralization, domestic institutions and domestic leaders played a decisive strategic role, launching negotiations and keeping a firm grasp on the proceedings.

Politically, in the 1990s eleven of the 15 EU members decided to lock together their currencies, realizing that they would get deprived of two powerful tools of macroeconomic polity such as the ability to devaluate and change their interest-rate (Dyson 2000). In addition, members knew they would be subject to a tougher fiscal discipline. Most of them were also well aware that domestic reforms in welfare, wage-policy, labor-market, would be needed in order to cope with the long term impact of a single currency in internal trade and international competition (Rose 1999; Ebbingaus and Hassel 1999). It means that the birth of the euro came at a high political cost for EU members. EMU undermined each member capacity to deliver its own political economy targeting its own domestic economy, and stripped them completely from the execution of monetary policy, a crucial tool they previously had to steer their domestic economies. It means that the EU has become more proactive and has achieved more power to control the actions and inactions of Eurozone members concerning their management of fiscal, budgetary and macroeconomic policies that, as a result, have been converging and are becoming standardized. This evolution is similar to what happened to an higher degree in tobacco policy (Duina and Kurzer 2004; Studlar, Christensen and Sitasari 2011), and to a lesser degree in other policy areas such as social and labor market protection policies (Leibfield and Pierson 1995; Sbragia 1992; Castles 1998) and morality policies such as abortion, alcohol, and drugs (Kurzer 2001). 


\subsection{The Achievement of Monetary Union: Federalism in Action since 1999}

The first decade after the introduction of the euro has represented mixed results. On the one side, it has featured the accomplishment of the federalization pattern on monetary issues. As a consequence, vertical federalism was seen in the delivery of a supranational monetary policy. However, on the other side, the decade has been characterized by a step back in economic integration represented by the relaxation of SGP rules. This is a case of "non-federalizing intergovernmentalism" because it did not target centralization and, as such, cannot be explained in terms of horizontal federalism that, according to my conceptualization, strengthens EC/EU institutions. Furthermore, the decade saw a resurgence of domestic politics when new recalcitrant member states politically postponed their entrance to the Eurozone. These features are presented in table 8 and analyzed in detail in the rest of this section.

The most important supranational evolution from a polity perspective concerned the monetary affairs. The most distinctive supranational features already included in the Maastricht Treaty - the regulation of EMU through the "Community Method" - has been emphasized in the Lisbon Treaty, since monetary issues have become an "exclusive competence" of the EU. The Lisbon Treaty also formally empowers the supervisory powers of the European Commission even if the political trend at that time was to ignore the enforcement of SGP. At any given time, the European Council has had the power to change the rules of the games, keeping a fundamental prerogative in balancing the power of EU institutions supposed to "think European" in their defense of supranational interests. However, the unanimity in the European Council is required in order to change the articles of the Lisbon Treaty pertaining to the European Central Bank System and EMU. 


\begin{tabular}{|c|c|c|}
\hline $\begin{array}{c}\text { EMU } \\
\text { Attributes }\end{array}$ & $\begin{array}{l}\text { Supranational } \\
\text { and Domestic } \\
\text { Levels }\end{array}$ & Monetary Union since 1999 \\
\hline \multirow{2}{*}{ Polity } & ECC/EC/EU & $\begin{array}{l}\text { EMU regulated through the "Community Method" and "Cooperation } \\
\text { Procedure"; ECB in charge of delivering monetary policy; Commission has } \\
\text { more powers after the Lisbon Treaty; EMU as "exclusive competence of EU" } \\
\text { (Lisbon Treaty)., ECBS reform requires Council unanimity. }\end{array}$ \\
\hline & Members & $\begin{array}{l}\text { Role of the European Parliament minimized; EcoFin; informal Eurogroup; the } \\
\text { Governing Board of ECB represents domestic governments; European Council } \\
\text { appoints ECB President and Executive Board; creation of the President of the } \\
\text { European Council (Liston Treaty). }\end{array}$ \\
\hline \multirow{2}{*}{ Policy } & $\mathbf{E C C} / \mathbf{E C} / \mathbf{E U}$ & Monetary policy delivered by the EU. \\
\hline & Members & $\begin{array}{l}\text { Council did not impose sanctions on SGP infringers; Council relaxed SGP } \\
\text { rules. }\end{array}$ \\
\hline \multirow{2}{*}{ Politics } & $\mathbf{E C C} / \mathbf{E C} / \mathbf{E U}$ & Commission could not enforce SGP sanctioning mechanism. \\
\hline & Members & $\begin{array}{l}\text { Germany and France obtained forgiveness for SGP infringers; euroskeptic new } \\
\text { members politically delayed their entrance into the Eurozone. }\end{array}$ \\
\hline \multicolumn{2}{|c|}{$\begin{array}{l}\text { Federalism Applied } \\
\text { to EMU Integration }\end{array}$} & Monetary federalism in action \\
\hline
\end{tabular}

Tab. 8 - Explaining EMU using a federalist structure (since 1999).

Whether the Lisbon Treaty is a constitution is debatable, but it is sure the legal basis upon which EMU is built on, qualifies for a constitutionalization process in a federalist framework, since provisions referring to the EMU clearly specify the functions at any level: both supranational (especially the European Central Bank and the European Commission) and domestic (domestic governments, the General Council of the European Central Bank composed by the governors of the national central banks of members). According to several scholars, these 
prerogatives typically pertain to a constitution (Hueglin 2000; Weiler 1999; Holzinger and Knill 2000; Börzel and Risse 2000; Fabbrini 2008).

The execution of monetary policy is highly centralized at the ECB level, a specialized agency empowered of delivering the monetary policy supposedly independent of political pressures. According to McNamara and Meunier (2002) and Savage (2005), the transfer of monetary policy to the European Central Bank denoted that a pan-European institutional layer was fully instituted, well advanced and presumably durable.

Not surprisingly, the US Federal Reserve system constituted an inspirational model to develop a European common currency, since the integration processes in the US and Europe have shown striking similarities (Fabbrini 2005) despite obvious and inevitable differences (Dyson 1994:31). More specifically, the comparison between the European Central Bank and the Federal Reserve Bank, and the European Central Bank System and the Federal Reserve System, has left little doubt about the similarity between the two. Apel (2003), Crowley (2001), and Sheridan (1996) argued that the way they were developed, the functions they perform, how they operate, the internal institutional design, the level of independence from political power are strikingly similar.

On the other side, looking at the constituents units side the European Council decided to limit the role of the European Parliament in EMU to mere consultation as a consequence of the French rejection of the European Constitution in a referendum held in 2005. Even though the exclusion of the European Parliament, the only elected EU institution parliament, has severe implications for the EU democracy, still the Council and the Commission balance each other. The EcoFin was somewhat obscured by the predominance of the Council, but still acted as the "members' guardian" towards the coordination of economic policy and economic surveillance, 
usually safeguarding members' interests than those of the EU. The Council, the EcoFin and the informal Eurogroup meetings (EcoFin restricted to Euroarea members), represented the interests of the increasing number of Eurozone members (from 11 in 1999 to 18 in 2014) counterbalanced the power granted to the ECB in managing the monetary policy and to the Commission to oversee members' fulfillment of their EMU obligations.

The creation in the Lisbon Treaty of the President of the European Council has created an institutional problem given the coexistence with the President of the European Commission. The Lisbon Treaty clearly identifies the President of the European Council as the main representative of the EU in international politics, but the President of the European Commission still holds formal powers (European Union 2012). In the case of EMU, when an economic problem is raised by the Council, it immediately steps into the economic policy prerogatives of the Commission. As such, there are various interpretations on the functions of the two positions; some predict they will be eventually fused in one figure, while others (Hix and Roland 2007) see a dual-presidential system that could lead to "cohabitation" as seen in France between the elected President of the Republic and the appointed Prime Minister. In any case, this is another feature showing a punctuated equilibrium between supranational and state-centric institutions.

An aspect that usually is not emphasized is the vertical federalism seen in the ECB balancing the power of supranational actors (the ECB's president and the ECB's Board) and actors representing EU members (the ECB's Governing Council). Furthermore, there is room for political interpretation of the division of labor between the ECB and Ecofin (De Grauwe 2002; Hix 2005:333) since the European Council appoints ECB President and ECB Executive Board. The pressure of the public opinion and domestic governments towards the central bank governors in the ECB's Governing Council is much higher than that observed in the Board of 
Governors of the Federal Reserve System that are supposed to act mostly independently once appointed. This is because the domestic governments see the ECB Governing Council as a political opportunity that central bank governors have to push for the delivery of a monetary policy fitting the economic cycle of their respective countries (Kaltenthaler 2006). On the one side, this negatively affected the credibility of the ECB, but on the other side it shows that the ECB as well can be seen as an example of vertical federalism.

From a policy perspective, since 1999 the execution of EMU has been delegated to the European Central Bank. The most striking policy evidence of a federalist evolution has been the complete shift of monetary sovereignty to the EU that complemented the already existing Single Market. The achievement of monetary union, however, was followed by the relaxation of the SGP rules. The Council also overruled the Commission's request to impose sanctions to members infringing the SGP requirements. A clear negative repercussion of this lack of enforcement has become evident in the following years, when the existence of the euro was threatened by the sovereign debt crisis, mainly caused by the irresponsible management of macroeconomic issues by the infamous "PIIGS" (Portugal, Ireland, Italy, Greece and Spain).

From a political perspective, thus, the Commission could not politically enforce the SGP sanctioning mechanism and had to play on the defense vis-à-vis the Council. Conversely, Germany and France were politically able to change the SGP rules given that they were persistently violating them. Finally, euroskeptic new member-states politically delayed their entrance into the Eurozone. NMS do not have the opportunity to opt out and are expected to eventually participate in the euro area. However, the Treaty foresees no calendar for participation because the timetable for participation for each individual member is subordinated to the substantive requirements of participation. This could be seen as a paradoxical catch-22 situation 
because an indefinite schedule due to the achievement of economic targets is a political opportunity for members to search for delays, because the fulfillment of economic criteria depends on political willing or reluctance to achieve them.

\subsection{Tackling the EMU Crisis since 2008 Targeting Federalist Solutions}

A growing strand of literature (Talani 2009; Hodson 2011) analyzed the causes and the consequences of the crisis reorienting the current debate towards the survivability of the Euro itself. Previously, the discussion was focusing on the prospective role of the euro in the international monetary system (Masson et al. 1997; Mundell and Clesse 2000) and on the enlargement of members not taking part yet in the Eurozone (Hosli 2005). Further, the authoritative press such as the Financial Times, the New York Times, and the Economist covered very closely on a daily or weekly basis the financial troubles that threatened the survivability of the Euro, providing very valuable material for the purposes of this dissertation: in-depth reportages, detailed analyses on future scenarios, headlines revealing behind the scene political negotiations, and commentaries full of theoretical implications.

The winner of the Nobel Prize Christopher A. Sims in 2002 predicted the crisis originated because of the precarious fiscal discipline of EMU (Sims 2002). Sims exactly foresaw what would happen: massive debt, rising interest rates on governments' bonds, increasing fiscal distress, aggressive speculation and the spread of the crisis to the point of threating the euro's survivability. As noted by Buonanno and Nugent (2013), this risk increased because the EMU featured one single currency, great economic differences among EU members, and weak political integration. With reference to the current turmoil, in 2002 Dyson appropriately forecast that the 
EMU yields "a high degree of uncertainty about its future. Its operation will display randomness and indeterminacy" (Dyson 2002:17). This position was confirmed by Barber (2010a, 2010b) when arguing that EMU had tall ambitions, but flawed foundations, fiscal indiscipline, design deficiencies, disreputable data, macroeconomic weaknesses, and rules designed for political expediency. Others believed that, despite warning headlines, worrisome commentaries, hysteric reactions, and fear of disaster, financial entanglement in a single financial market such as the EMU, featuring a single currency, no barriers, and macroeconomic asymmetries, should not be surprising ("Making eurozone safe from failure" 2010). In this regard, Kudrna (2012) observed that the EU takes action only after the problems are already evident. This being said, despite great progress already achieved in federalizing European economic and monetary governance, it seemed clear that more integration was needed to avoid the collapse of the single currency and, possibly, of the overall EU project.

Torres, Verdun and Zimmermann (2006), Dyson (2008), and Verdun (2012) share the concern that the euro was not backed by a fully-fledged federalist structure and consequently lacked the required institutional framework to deal with the management of an economic crisis. Verdun (2012) noted that in the 1990s EMU's design remained asymmetric, with economic integration lagging behind monetary unification, mainly for political reasons. As a result, there were many "economic leftovers" which have been revisited since the outbreak of the crisis. Even if Verdun did not make any specific reference to federalism, she clearly suggested the necessity of deeper political and economic integration in the future.

The rampant economic and financial turmoil that hit the Eurozone hard since 2009 represented an extraordinary opportunity to address the structural problems of EMU. As noted by Arestis and Sawyer (2011) and Feldstein (2012), in fact, the crisis has not been caused by "bad" 
behavior of some member states but rather by "design faults" of EMU. In fact, in the decade following the introduction of the euro, the violation of EMU rules became the norm by EU members. This could happen because the EU institutions were not really enforced to monitor members' fulfillment of their obligations and lacked the power of sanctioning in the case of violations.

Given the contemporary nature of the events under scrutiny, no detailed studies are yet available using an integrationist focus on the proposed solutions to tackle the crisis of the eurozone. This paper, thus, is aimed to fill a gap in the literature which currently addresses EMU. Since 2008, several proposals have been debated by European governments, EU and worldwide institutions to avoid the contagion of the Greek, Irish, Portuguese, Spanish and Italian crises. Among these proposals, up to now consensus emerged to address the future of the European Union and the euro area on (i) the creation of rescue funds (EFSM, EFSF and ESM) charged with disbursing loans for economies in difficulty, (ii) the "six-pack" reforms targeting a more stringent enhancement of macroeconomic, budgetary, and fiscal surveillance, (iii) the reinforcement of EU fiscal governance framework, comprised of the fiscal elements included in the "six-pack", the Treaty on Stability, Coordination and Governance (TSCG) and the "two packs", (iv) the unprecedented purchase by the ECB of government bonds refinancing sovereign debts (through SMP and OMT programs), (v) the Euro Plus Pact based on the Enhanced Cooperation procedure, according to which several members can decide on a voluntarily basis to advance integration in a specific policy area, and (vi) a banking union, introducing a single rulebook, common deposit protection, and a single bank resolution mechanism covering all banks in the Euroarea. 
The latest evolution of EMU since the inception of the financial crisis that has affected the Eurozone was recently analyzed through the lenses of integration theory, showing that the debate is still vibrant and controversial. As a result, a new wave of integration studies has updated the existing literature. On the one hand, several scholars such as Puetter (2009), Moravcsik (2012, 2013), and Glencross (2013) reaffirmed the centrality of the European Council as a prominent player acting as a de facto "presidential" actor (Kunstein and Wessels 2013). Taking a more critical stance, Fabbrini (2013a, 2013b) observed that "the extremely complex system of economic governance set up for answering the euro crisis has been defined and implemented on the basis of the intergovernmental constitution of the EU [but] the intergovernmental approach faced a structural difficulty in solving basic dilemmas of collective action" Fabbrini (2013a:1008). Similarly, Kunstein and Wessels (2013) noted that the attempt to centralize EMU policy has been complemented by the uneven application of EU rules in some members, causing differentiated forms of integration. Concerning other state centric approaches, analyses where produced looking at the domestic responses to the financial crisis in the cases of Southern Europe (Pagoulatos and Quaglia 2013) and the Baltic States (Vilpišauskas and Kuokštis 2013). On the other hand, a parallel process of empowerment EU institutions in the decisional process with the Treaty of Lisbon (assessing a more decisive role to the European Parliament) and centralization of EMU at the expenses of domestic sovereignties has produced papers reviving the neo-functionalist approach (Niemann and Ioannou 2013; Spendzharova 2013).

Looking at the mixed paradigm, Nugent and Buonanno (2013) wrote a chapter on EMU interpreted as a case of "federal integration model" merging the economic federalist theory as suggested by Balassa (1961) and a political perspective. Their conclusion is that the 
centralization seen in EMU resembles a typical example of federal policy development. If compared to Nugent and Buonanno, my dissertation aims to expand their focus on EMU policy to the political and polity implications of EMU evolving towards federalism. Another study looks at EMU from a two-level game perspective. Jabko (2013) argues that the divided sovereignty of the EMU is a byproduct of the conflict in the Maastricht Treaty between domestic and supranational sovereignly. I claim that the problem identified by Jabko can be answered looking at the long term evolution of EMU federalization, since the Maastricht Treaty represented the apex point of the previous twenty years of monetary integration. As for the conflict between supranational and domestic actors, I argue that it has constituted the norm in systems pursuing federalization. Another recent analysis mixing intergovernmentalism and supranationalism was provided by Radaelli, Dunlop and Kamkhaji (2013) when assuming that the solutions adopted to tackle the crisis since 2010 used both approaches. Finally, Snaith (2011) identified several relevant indicators of multi-level statehood showing that that EMU architecture can be classified as multi-level governance.

At first sight, it might seem paradoxical to introduce a federalist approach especially these days, when the euro is going through its first and most severe crisis threatening its own existence, yet I believe that the solutions (some just proposed and still under discussion, others already adopted) to solve the euro crisis are prototypically federalist. It is not a case that attention towards federalism is on the rise again in media, academic, and political circles after years of relative obscurity. Several press reports and editorials calling for a revived vision towards the "United States of Europe" appeared in the press (Urdank 2012), legitimizing the plausibility of the federalist approach, especially when applied to EMU. A conference organized in March 2012 by the Centre for European Policy Studies (CEPS) 
hosted academics and policy-makers who discussed the euro and economic governance from a federalist standpoint.

Habermas (2013) is the only one to have made a specific theoretical reference to the current institutional reforms as an attempt to transform the system of European governance into one of "executive federalism". Writing from a philosophical perspective on how political institutions can be extended beyond the level of nation-states, for Habermas this drive towards federalism is a mistake, because the post-national EU should evolve toward a cosmopolitan community. Translated to IR terminology, Habermas seems to take a constructivist stance, similarly to theorists of Europeanization which saw the EU as a regime with its own "exceptional" nature, and therefore in need of having specific theories to explain it.

In line with the overall evolution of EMU, the period since 2008 also offered interesting innovations from policy, polity, and political perspectives, all of which can be analyzed using my conceptualization of federalism (see table 9). From a policy standpoint, my hypothesis is that all the adopted supranational solutions are prototypically federalist. In this regard, Balassa (1961) identified a stage-based integration model whose path, logic and goal resembles a form of Economic Federalism. The first step is the creation of a free trade area made possible by the removal of internal tariffs, followed by a customs union (common external tariff), common market (free flow of capital, labor and services), economic union (harmonization of social, economic and sectorial policies), monetary and fiscal union (single currency and harmonized tax code), and political union (a federal state with an internal and external security apparatus). 


\begin{tabular}{|c|c|c|}
\hline $\begin{array}{c}\text { EMU } \\
\text { Attributes }\end{array}$ & $\begin{array}{l}\text { Supranational } \\
\text { and Domestic } \\
\quad \text { Levels }\end{array}$ & $\begin{array}{l}\text { Tackling the Ongoing EMU Crisis } \\
\text { (2008 up to date) }\end{array}$ \\
\hline \multirow{2}{*}{ Polity } & $\mathbf{E U}$ & $\begin{array}{l}\text { ECB in charge of monetary policy, in charge of administering loans, de facto } \\
\text { lender of last resort, and supervise European banks; European Parliament is a } \\
\text { co-legislator; Court of Justice as enforcer of the Fiscal Compact. }\end{array}$ \\
\hline & Members & $\begin{array}{l}\text { The Council and the Ecofin Council have peer-review powers; informal } \\
\text { Eurogroup has planning functions; domestic polities to be held accountable for } \\
\text { macroeconomic performance; grand coalition cabinets led by former EU } \\
\text { technocrats. }\end{array}$ \\
\hline \multirow{2}{*}{ Policy } & $\mathbf{E U}$ & $\begin{array}{l}\text { Rescue funds (ESM); the "six-pack" and the Treaty on Stability, Coordination } \\
\text { and Governance (TSCG) targeting stringent enhancement of macroeconomic, } \\
\text { budgetary, and fiscal surveillance; the purchase of government bonds } \\
\text { refinancing sovereign debts; the Euro Plus Pact; the banking union. }\end{array}$ \\
\hline & Members & Must fulfill more stringent macroeconomic, budgetary and fiscal criteria. \\
\hline \multirow{2}{*}{ Politics } & $\mathbf{E U}$ & $\begin{array}{l}\text { The Commission acted as a political entrepreneur for integration, role of the } \\
\text { president of the Commission enhanced, EBC played a political role. }\end{array}$ \\
\hline & Members & $\begin{array}{l}\text { The Council pushed for more integration; members politically committed to } \\
\text { policy reforms, austerity measures, spending cuts, tax increases, pay cuts, and } \\
\text { debt restructuring. }\end{array}$ \\
\hline \multicolumn{2}{|c|}{$\begin{array}{l}\text { Federalism Applied } \\
\text { to EMU Integration }\end{array}$} & Federalist solutions to achieve full economic union \\
\hline
\end{tabular}

Tab. 9 - Explaining EMU using a federalist structure since 2008

From the policy perspective, also, there is a certain affinity between the concept of economic federalism and "Optimum Currency Area" (OCA) defined as a region that shares a single currency to maximize economic efficiency. Mundell (1961) delineated four requirements 
denoting an OCA. The first one is capital mobility and openness among economies across the region, which is a requirement that the EU fulfills since the creation of the single market. The second one is labor mobility, which is technically possible for EU citizens but traditionally was rarely put into practice, given language barriers and cultural proclivity to find a job "close to home". However, in times of crisis, intra-EU mobility represents the solution for many searching for a job (see Galgóczi, Leschke and Watt 2012). The third one is the ability to mutualize the risk through mechanisms (such as fiscal transfers or bail-outs) aimed at redistributing funds to troubled countries of the region affected by asymmetric shocks. The lack of such devices at the EU level had negative repercussions on the functioning of the euro, but a permanent mechanism of mutual help and the reinforcement of EU fiscal governance framework has been debated and approved only after the inception of the 2008 crisis. Finally, countries sharing the common currency should have similar business cycles and seemingly economies in order to optimize monetary policy, which by definition must fit all economies. This is not the case of the EU, where huge differences exist across its 28 members, and most likely will remain in the future. In sum, while Europe scores well on the first measure since 1992, it is making adjustments on other two, getting closer to an OCA and, concomitantly, to an economic federation.

Looking at the European Stability Mechanism, the case-by-case approach in rescuing individual countries has been replaced by a permanent collective mechanism backed by all Eurozone countries and charged with disbursing loans for economies in difficulty. The way this safety net has been developed to contain the spread of the crisis affecting the survivability of the euro has features typical of a federal system for two reasons. The first one is that the permanent rescue mechanism represents a solidarity solution to mutualize the risk among constituents units (i.e. troubled Eurozone members). And secondly, the permanent ESM "turned the monetary 
union into a de facto debt union" ("Europe's Single Debt Zone" 2010: A17). The ultimate step toward a "de jure debt union" would be the issuance of Eurobond (or Stability Bonds, E-bonds) by a pan-European agency tentatively named European Debt Agency (EDA), backed collectively by all eurozone countries. This solution aimed at sharing members' indebtedness through the issuance of common euro debt was proposed but rejected in 2010, mainly because Germany opposed it, fearing that it would become a paymaster to cover other members' profligacy (Forelle and Walker 2010).

The "six-pack" reforms empower the European Commission (and eventually the ECB) to enact a more stringent enhancement of macroeconomic, budgetary, and fiscal surveillance through a gradual mechanism comprised of warnings, recommendations and automatic sanctions. The preventive and sanctioning arms at the disposal of the Commission were aimed at balancing "too much sovereignty and too little federalism" (Lannoo 2011:8) pre-crisis situation in policy monitoring, with members calling for sovereignty and power-politics when rules had to be respected, as if EMU was an intergovernmental construction. In 2005, for instance, the Council lifted the criteria of the SGP under the pressure of France and Germany which had excessive deficits at that time, showing a resurgence of intergovernmentalism (Vila Maior 2007). However, when the systemic crisis erupted, members and the Council reversed this attitude, showing propensity ambitiously to allocate more powers to the $\mathrm{EU}$ in the exercise of supervising the implementation of EMU policy at the domestic level.

The reinforcement of EU fiscal governance framework functional to the attempt at establishing a fiscal compact is another federalist milestone. As suggested by Musgrave (1959) and Oates (1972), Fiscal Federalism lays out a framework for the assignment of proper fiscal instruments at the various levels of government, in line with the functions they are 
constitutionally authorized to carry out. Since the central government should have the responsibility for macroeconomic control of the federal economy - together with monetary policy and control over exchange-rates of the federal currency - it derives that the central government should be entitled to a certain degree of fiscal prerogatives to be shared with constituent units.

The Euro Plus Pact, based on voluntarism to advance members' integration in a specific policy area, seems to be moved by two main purposes, which can be seen in the direction of targeting federalism. First, the plan was proposed by the French and German governments to facilitate economic convergence for countries who want (and need) eventually to adopt the euro in the future, to avoid the chaos occurring in Greece and to facilitate a smooth transition towards the common currency. The other interpretation is that the pact is linking the permanent EMS rescue mechanism not only for eurozone members, but also for eurozone candidates. From this perspective, this pact was requested by Germany as the price for being the main financial contributor of the ESM ("Pact for the Euro, What's in a name?" 2011).

The unprecedented purchase by the ECB in secondary markets of government bonds refinancing sovereign debts, means that the ECB had de facto acted as lender of last resort, providing financial support (or Emergency Liquidity Assistance) to sovereign debts of troubled Eurozone members and systemically important banks with problems of insolvency (Buiter and Rahbari 2012). Due to the impossibility to enact a treaty revision in the short run, the ECB's purchase of governments' bonds in secondary markets (and not directly from issuers) it is a subterfuge to circumvent Article 123 of the Treaty on the Functioning of the European Union (TFEU) that prohibits direct funding of the euro area debts by the ECB. As a matter of fact, the ECB has undertaken the same prerogative of any sovereign bank, as seen in other major world 
economies, not necessarily federalist systems (e.g. the Federal Reserve in the US), but also confederal systems (e.g. the Swiss National Bank), and centralized countries (e.g. the Bank of England and the Bank of Japan). The only difference among these models is whether the central bank is independent or not from political pressures, but the functions remain the same.

The first step towards a European banking union introducing a single rule book, common deposit protection, and a single bank resolution mechanism covering all banks in the Euroarea (and possibly involving non-euro members) has been already defined as a federal model by Carmassi, Di Noia and Micossi (2012). For them, the transfer of supervisory responsibilities and administrative powers in the banking sector to the ECB denotes a necessarily federal organization in a regulatory sense, at the crossroads of EMU and competition policy. Some other scholars have already highlighted that the EU is a type of regulatory federal organization that dictates the actions of its members in several policy areas (Sbragia 1992; Castles 1998; Cowles et al. 2001).

Nevertheless, Keleman (2004) noted that, similarly to other federal systems, in the EU most of policy decision is done by the EU Commission, while members are principally responsible for policy implementation. As such, the federalist framework requires a strict enforcement at the domestic level of the policies dictated by the EU. It means that in a federal framework, a policy to be successful needs a domestic counterpart which is equally important to the supranational one, ideally representing two sides of the same coin. It is true that, by definition, a country following EMU rules is a healthy country.

In the decade following the introduction of the euro, however, the violation of policy obligations became the norm, not only for the "usual suspects" but also for big economies such as France and Germany, as already reported above. Also, Italy, Greece, Spain, and Ireland 
extensively violated EMU since they were unable to avoid fiscal indiscipline, poor governance, protracted political instability, chronic lack of reforms needed to fulfill EU obligations, excessive public debt, and stagnant economies. The misconduct of these members created a grey area which grew bigger and bigger to the point of threatening the survivability of the euro. This is why since 2009 the EU has centralized the non-monetary aspects of EMU.

The lesson (hopefully) learned from the crisis is that economic governance needed to be tightened at the EU level and strictly implemented at the domestic level. Since the beginning of the crisis, in order to be recipient of the EU assistance channels, a Eurozone member has to commit itself to fundamental policy reforms, such as austerity measures, spending cuts, tax increases, pay cuts, and debt restructuring. This is not an easy task, given the spread of social unrest and the previous history of elusiveness, but due to the above mentioned reforms, an effective EU oversight on domestic economic governance should put into practice a fully-fledged EMU federalist system in the future.

Policy commitment is crucial for non-eurozone members as well, for various reasons. Firstly, they are ultimately expected to enter the Euroarea, which means they need to have sound public finances. Even if currently they are outside the euro, they are still very much affected by EMU since their currencies are either pegged to the euro, or fluctuate along with the euro (Schadler 2005). And finally, countries formally outside the Eurozone were to some extent affected by the financial crisis as countries inside the Eurozone.

From a polity perspective, more powers, authority and sovereignty were granted to EU institutions after the enactment of the reforms. Without a doubt, the European Central Bank, which already sat at the heart of EMU in executing monetary policy, is the most empowered institution since (i) it is in charge of administering loans to eurozone countries and banks 
experiencing financial difficulties, (ii) for the first time, it purchased governments bonds refinancing EU members' sovereign debts, and (iii) it is designed to supervise European banks. The Commission, representing the position of the EU, initiates legislation based on the Council of Ministers decisions. In addition, the Commission has been granted with more monitoring and sanctioning powers, if compared to the pre-crisis situation. Two European institutions, the European Parliament and the Court of Justice of the European Union, previously irrelevant to the management of economic governance, have been brought into the EMU. Since the Lisbon Treaty, the European Parliament is a co-legislator with the Council in the area of economic governance. Moreover, under the legal basis of TSCG, the Court of Justice of the European Union has taken on new powers as enforcer of the Fiscal Compact section of the TSCG by enacting penalties on non-compliant countries.

Looking at the other side of the polity structure, an intergovernmental body such as the Council of Ministers is entitled to designate broad policy-making targets to the Commission. The Council of Ministers also acts as legislator once a bill is introduced. The Ecofin Council was given the power of peer reviewing members' fulfillment of fiscal and macroeconomic obligations to prevent dangerous rules' infringements. This power equals the collective central enforcement mechanism enacted at the EU level by the Commission and the CJEU. I argue that this is a case of vertical federalism displaying a proper balance of power between the supranational and domestic levels.

From a domestic polity perspective, as already noticed above, members are empowered to enact supranational legislation within their domestic jurisdictions and have to ratify treaties in order to make them executable. In the domestic arenas, governments are responsible for executing proper fiscal and macroeconomic policies, take under control public debts and deficits, 
promote adequate reforms in line with EU obligations, achieve political stability and keep their economies competitive. This has been far from being achieved in the past, but federalism requires domestic polities to be held accountable, especially after a further shift of sovereignty towards the central government has taken place.

Political instability following the economic downturn has produced, in several troubled countries, grand coalition cabinets led by former EU technocrats. This is an aspect showing that EU politics and polity have become more prominent in domestic environments. In Portugal, early elections in 2011 where won by the Social Democratic Party led by Pedro Passos Coelho who was able to form a right-wing majority through a coalition. In Coelho's cabinet, the former director-general for research at the European Central Bank, Vitor Gaspar, served as Minister of Finance. In Greece, the resignation of Prime Minister George Papandreou in 2011 amidst political turmoil and social unrest paved the way for a government of national unity led by the technocrat Lucas Papademos, former Vice President of the European Central Bank. After the resignation of the centre-right Berlusconi executive in November 2011 Italy featured the technocratic government of Mario Monti, a former European Commissioner for Competition. It was a caretaker government in charge of driving Italy to the end of the legislature. Monti kept the budget deficit within the EU parameters in both 2012 and 2013, kept at bay speculators, and yields on Italian bond returned under control.

Politically, it must be noted that the general orientation of the Council of Ministers (via the usual horizontal federalism method), the Commission (acting as a political entrepreneur), and the European Central Bank has been that to redefine the rules pushing for more integration, i.e. seeking for federalist solutions. The main political objective of these solutions was to avoid the exclusion of troubled countries from the common currency, an option that would have produced 
a shock in the system with unimaginable consequences. The other option to be avoided at any cost was the creation of two different euro currencies (one for strong economies and one for smaller or troubled economies), an occurrence that would have deepened differentiated integration.

As always, the Commission acting as a political broker pushed for collective solutions to avoid the collapse of the euro. For instance, the EFSM has been defined as the "European Commission fund" (Walker 2010). The Commission was a crucial political driving force behind the establishment of federalist solutions, initiating secondary legislation on all of them under the auspices of the Council of Ministers. A possible exception of this scheme is the Banking Union, which looks like a byproduct of the Commission and the ECB. During the management of the crisis, the Commission understood the political necessity to share the risks and to create collective procedures covering all eventualities, especially in bad times (European Commission 2011b).

As well, the European Central Bank played an increasing political role, rather unusual by previous standards. In this regard, the President of the European Central Bank, Mario Draghi (2012) declared "the euro is irreversible. Within our mandate, the ECB is ready to do whatever it takes to preserve the euro. And believe me, it will be enough". Furthermore, in September 2012 the European Commission (2012) has published a proposal for a European banking union backed by the vice president of the European Central Bank Vítor Constâncio (2013).

Pressures on EMU caused by the international financial crisis have been shaping intergovernmental negotiations towards some crucial issues. The Council is entitled to designate broad policy-making targets to the Commission, which in emergency situations such as during the Eurozone crisis were directed towards the achievement of more integration towards a fully- 
fledged European Union, and not a renationalization of decision making (Barber 2010c), as it could have been expected. Rather quickly by previous standards, the decisions taken by the 17 euro members and the $28 \mathrm{EU}$ members clearly moved in a federalist direction.

\subsection{Conclusion}

Table 10 synthetizes my federalist structure in its entirety, previously broken down in four sections, merging empirical facts and my theoretical approach. My hypothesis is that the incremental writing of the rules of the game from the 1950s to 1998 (before the achievement of EMU) represented a form of horizontal federalism targeting the federalization of economic and monetary affairs. This phase has been facilitated by several federalist supporters in Europe, as well as by the intervention of the United States in European affairs after WWII in both real and inspirational terms, given that the US Federal Reserve system constituted a model to develop a European common currency. Early pioneering and "utopian" discussions concerning the idea of a common currency took place in the 1950s and the 1960s, in a polity dominated by domestic sovereignty that made the European Economic Community (EEC) appears to be a loose and unambitious international organization. In fact, the governments of the six members had mere consultations in macroeconomic policy and largely ignored the few monetary provisions they had already agreed upon. In such a context indisputably controlled by domestic politics, however, a customs union, the European Payments Union (EPU) and the European Monetary Agreement (EMA) became effective in the 1960s, showing some progress made by domestic governments towards the federalization of economic and monetary affairs. A customs union consisting of the elimination of tariff barriers was achieved at the end of the 1960s. 


\begin{tabular}{|c|c|c|c|}
\hline \multirow{2}{*}{$\begin{array}{c}\text { EMU } \\
\text { Attributes }\end{array}$} & \multirow{2}{*}{$\begin{array}{l}\text { Supranational } \\
\text { and Domestic } \\
\text { Levels }\end{array}$} & \multicolumn{2}{|c|}{ EMU - Historic Evolution } \\
\hline & & $\begin{array}{l}\text { Onset of Economic Integration } \\
(1950 \mathrm{~s}-1968)\end{array}$ & $\begin{array}{c}\text { Towards a Single Currency } \\
(1969-1998)\end{array}$ \\
\hline \multirow[t]{2}{*}{ Polity } & $\mathbf{E C C} / \mathbf{E C} / \mathbf{E U}$ & $\begin{array}{l}\text { Treaty of Rome, creation of the High } \\
\text { Authority/Commission; five economic- } \\
\text { related Committees and the } \\
\text { Assembly/Parliament, mainly with } \\
\text { advisory and technocratic functions on } \\
\text { domestic macroeconomic and monetary } \\
\text { policies. }\end{array}$ & $\begin{array}{l}\text { In the 1970s some authority moved in ECC } \\
\text { institutions and advisory/technocratic functions } \\
\text { enhanced; QMV extended; in } 1979 \text { first direct } \\
\text { election of the European Parliament which in } \\
\text { the 1980s acquired a legislative role; in the } \\
1990 \text { s the Commission increased his } \\
\text { monitoring powers; in } 1999 \text { the European } \\
\text { Central Bank established. }\end{array}$ \\
\hline & Members & $\begin{array}{l}\text { Council of Ministers leading the EEC } \\
\text { decisional process; governments' } \\
\text { sovereignty on macroeconomics and } \\
\text { monetary policies. }\end{array}$ & $\begin{array}{l}\text { Creation of the European Council setting } \\
\text { policy targets and macro-directions in EMU; } \\
\text { creation of the EcoFin, the main decision- } \\
\text { making body of EMU }\end{array}$ \\
\hline \multirow{2}{*}{ Policy } & $\mathbf{E C C} / \mathbf{E C} / \mathbf{E U}$ & $\begin{array}{l}\text { European Economic } \text { Community, } \\
\text { Customs union, European }\end{array}$ & $\begin{array}{l}\text { The Barre Report, the Werner Report, the } \\
\text { Snake in a Tunnel, European Monetary } \\
\text { System, the Single European Act, the Delors } \\
\text { Report and the Maastricht Treaty, the Single } \\
\text { Market; EMU. }\end{array}$ \\
\hline & Members & $\begin{array}{l}\text { Removed trade } \\
\text { committed but } \\
\text { mactrictions; formally } \\
\text { coordination. }\end{array}$ & $\begin{array}{l}\text { Still elusive in the 1970s, enacted } \\
\text { macroeconomic coordination in the 1980s, } \\
\text { fulfilled convergence criteria in the 1990s } \\
\text { elusive on SGP requirements after joining the } \\
\text { euro. }\end{array}$ \\
\hline \multirow{2}{*}{ Politics } & ECC/EC/EU & $\begin{array}{l}\text { The High Authority/Commission } \\
\text { interpreted extensively the Treaty of } \\
\text { Rome, pushed for more macroeconomic } \\
\text { coordination, and proposed program } \\
\text { towards common market and monetary } \\
\text { union. }\end{array}$ & $\begin{array}{l}\text { The Commission acted as a political } \\
\text { entrepreneur for integration, role of the } \\
\text { president of the Commission enhanced. }\end{array}$ \\
\hline & Members & $\begin{array}{l}\text { Narrow interpretation of the Treaty of } \\
\text { Rome, diluted coordination into } \\
\text { consultation, reluctant to pool } \\
\text { sovereignty but gradually granted } \\
\text { concessions to the EEC in economic } \\
\text { realm. }\end{array}$ & $\begin{array}{l}\text { End of Gaullist era, politicization of monetary } \\
\text { issues, German-French axis, politically } \\
\text { accepted redistribution of sovereignty in the } \\
1970 \text { s, targeting macroeconomic coordination } \\
\text { in the } 1980 \text { s and convergence in the } 1990 \text { s. }\end{array}$ \\
\hline \multicolumn{2}{|c|}{$\begin{array}{l}\text { Federalism Applied } \\
\text { to EMU Integration }\end{array}$} & Federalization of economic affairs & $\begin{array}{l}\text { Federalization of monetary issues (1970s) and } \\
\text { economic affairs (1980s) }\end{array}$ \\
\hline
\end{tabular}

Tab. 10 - Explaining EMU using a federalist structure 


\begin{tabular}{|c|c|c|c|}
\hline \multirow{2}{*}{$\begin{array}{c}\text { EMU } \\
\text { Attributes }\end{array}$} & \multirow{2}{*}{$\begin{array}{l}\text { Supranational } \\
\text { and Domestic } \\
\text { Levels }\end{array}$} & \multicolumn{2}{|c|}{ EMU - Historic Evolution } \\
\hline & & Monetary Union since 1999 & $\begin{array}{l}\text { Tackling the Ongoing EMU Crisis } \\
\text { (2008 up to date) }\end{array}$ \\
\hline \multirow{2}{*}{ Polity } & $\mathbf{E C} / \mathbf{E U}$ & $\begin{array}{l}\text { EMU regulated through the "Community } \\
\text { Method" and "Cooperation Procedure"; } \\
\text { ECB in charge of delivering Monetary } \\
\text { policy; Commission have more powers } \\
\text { after the Lisbon Treaty; EMU as EU } \\
\text { "exclusive competence" (Lisbon Treaty); } \\
\text { ECBS reform requires Council } \\
\text { unanimity. }\end{array}$ & $\begin{array}{l}\text { ECB in charge of monetary policy, in charge of } \\
\text { administering loans, de facto lender of last } \\
\text { resort, and supervise European banks; } \\
\text { European Parliament is a co-legislator; Court } \\
\text { of Justice as enforcer of the Fiscal Compact. }\end{array}$ \\
\hline & Members & $\begin{array}{l}\text { Role of the European Parliament } \\
\text { minimized; EcoFin; informal Eurogroup; } \\
\text { the Governing Board of ECB represents } \\
\text { domestic governments; European } \\
\text { Council appoints ECB President and } \\
\text { Executive Board; creation of the } \\
\text { President of the European Council } \\
\text { (Liston Treaty). }\end{array}$ & $\begin{array}{l}\text { The Council and the Ecofin Council have peer- } \\
\text { review powers; informal Eurogroup has } \\
\text { planning functions; domestic polities to be held } \\
\text { accountable for macroeconomic performance; } \\
\text { grand coalition cabinets led by former EU } \\
\text { technocrats. }\end{array}$ \\
\hline \multirow[t]{2}{*}{ Policy } & $\mathbf{E C} / \mathbf{E U}$ & Monetary policy delivered by the EU. & $\begin{array}{l}\text { Rescue funds (ESM); the "six-pack" and the } \\
\text { Treaty on Stability, Coordination and } \\
\text { Governance (TSCG) targeting stringent } \\
\text { enhancement of macroeconomic, budgetary, } \\
\text { and fiscal surveillance; the purchase of } \\
\text { government bonds refinancing sovereign debts; } \\
\text { the Euro Plus Pact; the banking union. }\end{array}$ \\
\hline & Members & $\begin{array}{l}\text { Council did not impose sanctions on } \\
\text { SGP infringers; Council relaxed SGP } \\
\text { rules. }\end{array}$ & $\begin{array}{l}\text { Must fulfill more stringent macroeconomic, } \\
\text { budgetary and fiscal criteria. }\end{array}$ \\
\hline \multirow{2}{*}{ Politics } & $\mathbf{E C} / \mathbf{E U}$ & $\begin{array}{l}\text { Commission could not enforce SGP } \\
\text { sanctioning mechanism. }\end{array}$ & $\begin{array}{l}\text { The Commission acted as a political } \\
\text { entrepreneur for integration, role of the } \\
\text { president of the Commission enhanced, EBC } \\
\text { played a political role. }\end{array}$ \\
\hline & Members & $\begin{array}{lccc}\text { Germany and } & \text { France } & \text { obtained } \\
\text { forgiveness for } & \text { SGP } & \text { infringers; } \\
\text { euroskeptic new members } & \text { politically } \\
\text { delayed their entrance into the Eurozone. }\end{array}$ & $\begin{array}{l}\text { The Council pushed for more integration; } \\
\text { members politically committed to policy } \\
\text { reforms, austerity measures, spending cuts, tax } \\
\text { increases, pay cuts, and debt restructuring. }\end{array}$ \\
\hline \multicolumn{2}{|c|}{$\begin{array}{l}\text { Federalism Applied } \\
\text { to EMU Integration }\end{array}$} & Monetary federalism in action & $\begin{array}{l}\text { Federalist solutions to achieve full economic } \\
\text { union }\end{array}$ \\
\hline
\end{tabular}

Tab. 10 (continued) - Explaining EMU using a federalist structure 
A certain degree of monetary cooperation was provided by the EPU (1950-1958), a system that allowed countries with a trade deficit to transfer their liabilities to the EPU, which worked as a credit line which had to be ultimately settled in US dollars and gold. Essentially, the EPU provided a sort of multilateral umbrella to prevent market distortions, promote intraEuropean trade, and cope with the structural inconvertibility of currencies with the only exception of the US dollar. The EPU worked until 1958, when it was replaced by the EMA, a multilateral settlement which restored the external convertibility of members' currencies in the framework of the Bretton Woods system.

Such progress became more tangible in the 1970s from any standpoint. In policy terms, material steps were taken towards monetary unification after the full achievement of a customs union. Monetary unification was a theme that gained momentum after the collapse of the Bretton Woods Agreements. As such, the Werner Report unsuccessfully targeted a monetary union in 1980 but represented a fundamental source of inspiration for the later evolution of EMU. The "Snake in the Tunnel" was a technical solution adopted since 1972 by EEC members aimed at keeping the flotation of European currencies against each other under control. More precisely, a narrow band $( \pm 2.25 \%)$ to reduce the magnitude of intra-currency fluctuations was set for currencies to move relative to their central rate against the US dollar. This provided a "tunnel" in which European currencies to trade.

And finally the European Monetary System (EMS) in 1979 represented the prerequisite to move forward and seek an economic and monetary union. The EMS and its centerpiece, the Exchange Rate Mechanism (ERM), was as an arrangement set to stabilize European currencies and European economies after the collapse of Bretton Woods in 1971, which was based on the stable US dollar as an anchor currency in the international monetary system. This integrationist 
trajectory finally culminated with the Maastricht Treaty in 1992, laying down the three steps to achieve EMU in 1999. Politically, in this period the European Commission as an independent political entrepreneur pushed for the process of European integration, being able to compete with the traditionally more powerful European Council and members' governments. Also, the various EEC Committees dealing with monetary and economic affairs played a prominent role, advising politicians from a technocratic perspective. As a result, the polity changed too. Domestic sovereignty started to shift with some authority moved to the European institutions, the Single Market was deemed to have been completed in 1992 and the monetary union was en route to be finally achieved in 1999. Concerning this period, I believe that federalism can explain (i) the rising power of EEC/EU polity vis-à-vis domestic governments, (ii) the competing political pressures coming from both national governments and European institutions, and (iii) the progressive federalization of economic and monetary policies.

The third step represented the real game changer, defined by the EMU in action for the financial markets since 1999 and the real circulation of the euro coins and bills since 2002. The most striking evidence of a federalist evolution has been the complete shift of monetary sovereignty toward the EU that complemented the already existing Single Market. Translated in legal terms (Article 3 of TFEU), the EU has an "exclusive competence" in executing monetary policy for the member states whose currency is the euro. In this regard, monetary policy is not only an EU affair, but its execution is highly centralized at the ECB level, a specialized agency empowered to execute the monetary policy supposedly independent of political pressures.

In political terms, the informal Eurogroup meetings and the Economic and Financial Affairs Council (ECOFIN) representing the interests of the increasing number of Eurozone members (from 11 in 1999 to 17 in 2010) counterbalanced the power granted to the EU in 
managing the monetary policy. In fact, at any given time, the European Council has had the power to change the rules of the games, keeping a fundamental prerogative in balancing the power of EU institutions who are supposed to "think European" in their defense of supranational interests. This polity equalizing supranational and domestic institutions reflects the division of competences (and the consequent feedback loop) between two levels of government, and is typically seen in federal systems.

The fourth phase of EMU evolution dealt with the rampant economic and financial turmoil that has hit the eurozone hard since 2009. It represented an extraordinary opportunity to readdress the structural problems of EMU. Hence, not surprisingly, since 2010 the European Council has debated several solutions. Among these proposals aimed at enforcing EMU, consensus emerged on several options. My hypothesis is that these measures are prototypical federalist policies. As such, they promoted a federalist evolution of the EU economic governance, from a polity, policy and political perspective. From a policy standpoint, the first measure involved the tightening of domestic fiscal policies functional to the attempt of establishing a Fiscal Compact.

From a polity perspective, the European Central Bank for the first time purchased governments' bonds refinancing EU members' sovereign debts, acting as a de facto lender of last resort, like the Federal Reserve in the US. Moreover, the role of EU institutions has been enhanced in monitoring members' fulfillment of fiscal and macroeconomic obligations and in preventing dangerous rule infringements.

The main political objective of these solutions was to avoid the exclusion of Greece and other troubled countries from the common currency, an option that would have produced a shock in the system with unimaginable consequences. The other option to be avoided at any cost was 
the creation of two different euro currencies (one for strong economies and one for smaller or troubled economies), an occurrence that would have deepened differentiated integration and worked against a federalist approach. Politically, it must be noted that the general orientation of both the European Council (via horizontal federalism) and the Commission (acting as a political entrepreneur) has been to redefine the rules in a federalist direction. In this institutional framework, the European Central Bank played an increasingly political role, rather unusual by previous standards. 


\section{Conclusion}

The aim of this dissertation was to introduce a research design testing the federalist approach as a theoretical paradigm in which EMU takes place. I analyzed EMU as an example of policy that evolved through political entrepreneurship and polity reconfiguration. My argument is that federalism intended as a mixed theory provides a better explanation of the overall EMU process. This is because everything in EMU can be explained as a matter of balance between the actors involved in EMU. On the one side, as noted by Tsoukalis (1970:170) "it would be erroneous to base a strategy for economic and political integration mainly on the supranational institution", as neo-functionalists had claimed. In fact, domestic actors were (and still are) pivotal in progressing EMU. As such, I rejected the two alternative hypotheses presupposing that state-centric or supranational approaches are superior to mixed ones in explaining EMU.

My definition of federalism as a structure where domestic and supranational impulses dialectically engage is aimed to fix some theoretical inaccuracies. It includes the role of the EU (unlike state-centric approaches), it takes into account the role of domestic factors (unlike neofunctionalism), and it presupposes a dependency path among policy areas reliant on both domestic and supranational factors (unlike neo-functionalism, which only takes into account the latter). I argued that multi-level governance can be seen as a broader view of federalism. I finally challenged the Europeanization constructivist stance, according to which the EU is a supranational body unlike anything seen before in history; hence it needs its own theories to be explained.

From the theoretical perspective, I considered the degree to which EMU could be conceived as a case of federalism. To this aim, I examined the existing federalist literature to 
identify and extrapolate its most relevant concepts, generate some hypotheses and expectations, and thereafter determine whether the overall evolution of EMU could be reasonably classified as "federalist". Following my hypothesis, the various concepts elaborated from federalist theory are able to give a synoptic picture of EMU, highlighting the dynamic and constitutive development of EMU. In sum, I believe that applying federalism to EMU encompasses other contending approaches in one theoretical focus, providing a parsimonious, structural, multilayered and dialectic explanation. It is parsimonious because a single theory can explain the overall evolution of EMU. It is structural because it conceives federalism as a framework. It is multilayered because takes into account both domestic and supranational actors. It is dialectic because it explains the tensions between the domestic and supranational actors. The dialectic attribute applies also to the oscillation between the writing of the rules (mainly by the European Council and the EcoFin), policy execution by the European Commission and the ECB, policy implementation by EU members, and back to the rewriting of the rules when needed.

Considering federalism as an institutional architecture and a form of statehood implies considering it as an empirical fact and a real structure in which EMU takes place. This aspect is inherently linked with the "how" EMU could happen. I believe that federalism gives a proper answer to analyze how EMU has been politically developed, how policies have been implemented, and how the polity has changed over the decades. Federalism is the mechanism through which EMU could happen and operates. In line with process tracing assumptions, I assumed that EMU developed in a federalist direction, since the issues of timing, sequencing, incrementalism, fluctuation between inertia and impulse toward integration, experimentation, interaction effects, and the relevance of key events were particularly manifest. 
I believe that from the very beginning, horizontal federalism has been targeting centralization as an outcome. In such way, horizontal federalism has been the process, whilst vertical federalism has been its outcome. Horizontal federalism occurred when the Council of Ministers (EcoFin) and the European Council negotiated and decided the rules of the games with minimal involvement of the ECC/EC/EU institutions. In both economic and monetary realms, this process led to the emergence of a central authority such as the Commission, the European Parliament and the European Central Bank still encapsulated in a two-layered federal structure. I assume that horizontal federalism approximates the concept of bottom-up Europeanization, while there is a difference between horizontal federalism and intergovernmentalism: the former is targeting federalization, while the latter is not.

I argue that "horizontal federalism" is something more than pure intergovernmentalism, since the outcome of the constituents units in setting the rules of the game is further integration. In the case of the EMU, the EU members decided about a full delegation of monetary policy at the EU level. As for the economic union, the process is still on the making and is still open ended, but the recent economic downturn worked to strengthen European institutions vis-à-vis EU members. The original theorization of intergovernmentalism developed by Hoffman (1965) and politicians like De Gaulle was not supposed to predict further integration but a loose pooling of sovereignty at the EEC/EU level and domestic governments still in control of EMU polity, policy and politics. Liberal Intergovernmentalism defined by Moravcsik targeting centralization given certain conditions is a recent permutation of intergovernmentalism that is conceptually stretching its definition of intergovernmentalism to the point of losing its original meaning. An example of pure intergovernmentalism is the lack of sanctioning for SGP infringers in 20032005 and the subsequent relaxation of the SGP pact in 2005 that empowered negligent domestic 
governments, undermined integration and caused major problems with the inception of the economic downturn in 2008. Another example of intergovernmentalism can be identified in the EU foreign policy. Although it has recently seen a formal evolution with the establishment since 1999 of the "High Representative of the Union for Foreign Affairs and Security Policy", practically still today the various domestic foreign policies predominate over the EU one.

The result of horizontal federalism has been the inevitable and progressive loss of sovereignty of the constituent units in an increasing number of economic and monetary areas, similarly to the neo-functional theorization of policy spillover. However, it does not mean that the EU members totally lost the control of the process, because the European Council is entitled of setting the macro targets of EMU and, as such, change the EMU rules; the European Council and the EcoFin are legislators in the policymaking process of EMU; and the Governing Council of the ECB is an arena where central bankers can defend the position of their respective countries and push for a formulation of monetary policy accordingly.

In this regard, vertical federalism denotes the allocation of power and the division of competences between the "mandating" central government and the "mandated" constituent units. In sum, vertical federalism explains the role of the actors in sharing policy attributions. In such a framework, the role of EEC/EU institutions should not be dismissed. A close look at the original documents shows a constant call of the EEC/EU institutions for the need of coordination among members and policy harmonization. At the beginning this occurred only in the economic field, later this call was extended to monetary issues, and in the last twenty years on budgetary and fiscal issues. In this regard, it is interesting to note that the patterns of collaboration among actors changed over time, since sometimes the Commission and its presidents (i.e. Roy Jenkins in late 
1970s and Jacques Delors in late 1980s) took the lead "preceding" the Council in indicating the future direction of integration.

In presenting my approach I decided to expunge the term "confederation" to avoid confusion. Confederation has been variously used to analyze the EEC especially at its earlier stages and sometimes as an equivalent of horizontal federalism or intergovernmentalism. However, there is not agreement on the boundary between "confederation" and "federation" because the international system lacks of stable confederations. Therefore "federalization" is a key term that I applied to EMU. I believe that "federalization" is more appropriate since it denotes a shifting power over time towards the central EU government getting more authority but with the decentralized level (the EU members) still balancing it in various ways.

Another problem is that not all confederations necessarily develop into a federation. For example the Commonwealth of Independent States (CSI) formed after the collapse of the Soviet Union comprises Russia and several independent countries that used to be former Soviet Republics. The CSI started as a loose confederation that has decayed over the years, mainly because former Soviet politicians that were still controlling the politics of their respective countries after the collapse of the Soviet Union progressively lost the control of them. Now these countries are run by a new generation of leaders without links with the Soviet past and, as such, not interested in enforcing the CSI.

Federalization in EMU did not happen linearly but fluctuated between economic and monetary integration. Economic integration took place in the 1950s and 1960s and culminated with the customs union. It was followed by a push for monetary integration in the 1970s, leading to the establishment of the European Monetary System. In the 1980s a new wave of economic integration was finalized with the achievement of the Single Market in 
1992. The following decade was focused on establishing a monetary union, achieved in 1999 for the financial markets and in 2002 with the circulation of the euro. The first ten years after the introduction of the euro has represented mixed results featuring federalism on monetary issues but a step back in economic integration, given the relaxation of SGP rules. However, the current wave of integration in macroeconomic issues started in 2009 targeting a fullyfledged economic union is the result of that retreat and of the crisis that has affected the Eurozone since the 2008 .

In federalization terms, the single market has been a target of the EEC/EU since the Treaty of Rome in 1957, while the achievement of a monetary union has been mentioned for the first time at the Hague Conference in 1969. It took 35 years to achieve a single market and three decades to achieve monetary union. Since 2002 nobody challenges the evidence that the EU is a monetary union, since a single currency, a single monetary authority, and a single monetary policy across the Euroarea have been put into effect. The progress was being made possible by adopting a progressive sequencing from the European Monetary Agreement, to the Snake in a Tunnel, the European Monetary System, the Single European Act, and the Maastricht Treaty.

One of the pillars of an economic union, the idea to promote financial solidarity and mutual assistance among ECC/EU members, was the first monetary provision put into practice in the 1950s with the European Payments Union. Later, it became a recurring theme on various occasions, with the establishment of a more complex European Monetary Cooperation Fund in the 1970s and the permanent European Stability Mechanism in 2012. The latter can be said to have prevented the collapse of the euro by providing financial help to Eurozone members experiencing deep economic difficulties. 
Economic integration paralleled the achievement of a common currency. It was initiated in the 1950s with the common market for coal and steel, followed by the achievement of the customs union at the end of the 1960s, the realization of the single market in 1992 and the economic union "technically" inaugurated in 1999. However, if an economic union is defined as a single market featuring common competition, structural and regional policies, and macroeconomic policy coordination, including binding rules for budgetary policies and fiscal and banking unions, then today the EU is not a full economic union. The "economic leftovers" being addressed since 2009 represented the weakest components of EMU, i.e. budgetary, fiscal, and banking policies, still predominantly driven by domestic politics. This is a necessary step to complete the economic union, still going on today, whose outcome is still open-ended.

As well, the coordination of macroeconomic issues showed a fluctuating route. From a macroeconomic perspective, the progressive shift from mutual information, mere consultation, active coordination, fair cooperation, policy harmonization necessary to establish a single market and the subsequent convergence to an economic union has been a thorny route. Up to the end of the 1970s members were formally committed but elusive on fulfilling the provisions coming with EEC membership. This attitude changed in the 1980s, when for the first time they achieved a certain degree of macroeconomic convergence and remained engaged in fulfilling the convergence criteria to join the euro. However, after the inception of the euro, they became more elusive on respecting the Stability and Growth Pact, since several members in one way or in another infringed its rules, the SGP pact was relaxed and infringers were forgiven, showing a return to pure intergovernmentalism. When the 2008 the global turmoil hit Eurozone members, the Council of Ministers decided to establish more stringent criteria and a more rigorous fulfillment of EU obligations by its member-states. 
I also believe that more countries from Central and Eastern Europe will join the euro after the financial and economic turbulence comes to an end. I am aware of the limitations and perils in providing predictions based on contemporary events whose outcome is still open-ended. However, I believe that the current negotiations show a federalist stance. Since the inception of the crisis, the debate over the survivability of the euro fluctuated between two opposite trends: on the one hand, actors seeking for more integration towards a fully-fledged European Union; on the other hand, an escape from the EU towards a partial renationalization of decision making. It seems that the latter option has been avoided at any cost, preferring the federalist one. Since in these days (May 2014) the European economies are recovering, it seems relatively easy to claim that more integration has been the solution to tackle the economic downturn, but I formulated this hypothesis in 2011, when the collapse of the monetary union together with serious risks for the survivability of the EU was a possibility.

Why has EMU progressed despite extremely diversified domestic interests, the initial formal but not substantial commitment of EU members towards the EMU project, the setbacks and stagnation in the integration process, the ideological resistance to give up sovereignty to the $\mathrm{EU}$, and the repeated crises that periodically have been affecting the integration process? The reason is that in order to tackle the trend of globalization of economics, in the long run members perceived it to be more necessary for their economic interests to centralize the execution of monetary policy at the EU level and to create a single market. From this perspective, federalism as a form of statehood in economic and monetary affairs has represented a precise choice. As such, EEC/EC/EU and domestic actors have been always seeking supranational solutions, in line with the systemic nature of the challenge. When a systemic crisis threatened in various ways domestic economies, the proposed solution from the Council of Ministers and the Commission 
was to promote further integration. The first integrationist wave took place with the achievement of the customs union to avoid the conditions leading to the brutality of World War II. The second trend occurred in 1979 with the launch of the European Monetary System as an arrangement to stabilize European currencies after the collapse of Bretton Woods in 1971. The attainment of the Single Market in 1992 can be seen as a direct response to the rising competitiveness of the Japanese economy in the 1980s. The achievement of a monetary union was a direct consequence of the end of the Cold War that caused fears in Europe towards a too powerful Germany after its unification. Finally, I believe that the current attempt to seek a fiscal and banking union, together with the enhancement of macroeconomic and budgetary surveillance and the rescue funds mutualizing the risks of a sovereign default, represents an integrationist reaction to tackle the rampant economic and financial turmoil that hit the eurozone since 2008.

Following Wiener and Diez (2004:241) categorization along the functions of a theory (explanatory/understanding, analytical/descriptive, and critical/normative) and taking into account areas of applicability (polity, policy and politics), I argue that federalism applied to EU economic governance represents a legitimate theoretical paradigm. This does not mean that the EU can be deterministically seen as a full-fledged federation in any given policy area. In order to do so, there needs to be more direct comparison with institutional processes for other categories of policies, and frequencies of the use of different institutional venues should be compared. My intention was to show that federalism has the power to explain the overall complexity of the EMU project from its beginning to current troubles.

A related question is whether EMU is as a policy template for other EU policies. Is it EMU a model for integration to be applied in other policies? I believe that more studies are necessary to answer these questions. This is due to the fact that, as noted by Studlar (2010), 
federal systems have different authority patterns for policies. As such, this is a reason according to which it is difficult to generalize about this topic. The reason for progressive centralization in EMU could have depended on the specific (economic and monetary) policy under consideration, which at least after WWII has been subject to progressive globalization and hence elicited a supranational response. Other fields like environmental and immigration policies have escaped the boundaries of nation-states and represent global challenges, thus could denote a similar pattern as that occurred in the economic globalization. It is not a case that EMU, environmental and immigration policies in the EU are couched in a vertical type of federalism, implying some hierarchy and patterns of positive integration. Other areas, like foreign policy, seem to be still dominated by domestic impulses, even though studies analyzing the EU as a global power are flourishing.

As for planned dissertation extensions, a future project focusing on the European Union is a comparative analysis of the other five policies in which the EU currently has exclusive competence. In particular, these competences are as follow: 1) customs union, 2) the establishing of the competition rules necessary for the functioning of the internal market, 3) monetary policy for the member states whose currency is the euro, 4) the conservation of marine biological resources under the common fisheries policy, 5) common commercial policy. This research is intended to find whether these policies, intended to be solely decided by the EU, share common features or have distinctive differences in terms of policy setting (formulation, implementation, evaluation). The overall goal is to provide normative prescriptions on other areas such as foreign and fiscal policies, should they become subjected to a more critical role from the EU in future, as many commentators expect. 
Secondly, assuming that any major systemic economic, monetary, and financial crisis across seven decades since WWII has constituted a turning point in advancing further integration, it means that I included a third level - the international one - in this research design, together with domestic and supranational levels. In this sense, the international order triggered the need for integration, while the domestic and supranational levels made it possible. Another extension of the research design would be constituted by the inclusion of transnational actors such as the International Monetary Fund (IMF), which together with the European Central Bank and European Commission, have been recently known as "the troika" in charge of administering loans to the troubled economies.

Thirdly, several theories have been recently developed to explain EMU integration. These are "policy modes" (Wallace et al. 2005), "new governance modes" (Tömmel and Verdun 2009), "fusion theory" (Miles, forthcoming), and cosmopolitanism (Habermas 2012). These innovative explanations could be tested vis-à-vis mainstream theories I have compared in this dissertation, including federalism. Fourthly, a comparison involving the patterns of federalization and the features of vertical and horizontal federalism in monetary issues between the EU and other federations (like Canada, the US, Switzerland, and Australia), would be appropriate.

Later research might include configuring an intra-regional comparison with the tentative project of an Asian single currency, which so far only exists in the minds of economists and officials within international organizations. However, a possible scheme based on a "basket" or weighted average of currencies used in the 10 ASEAN member countries plus South Korea, China and Japan, has been framed by the Asian Development Bank. Growing literature on this topic suggests that domestic outputs of East Asian countries are strongly influenced by countryspecific shocks, deriving that these countries are structurally different from each other and thus 
likely to be subject to asymmetric shocks. Given these assumptions and my initial findings on the EU Monetary Union, my research yields the need for future comparative research is whether a common currency in East Asia would be more costly and difficult to sustain than in the EU case. 


\section{Bibliography}

A contagious Irish disease? (2010). The Economist, November 27.

Alderman, Liz (2010). "Worries About Italy and Belgium in EuroZone”, The New York Times, December 1.

Allam, Miriam S. and Achim Goerres (2008). "Adopting the Euro in Post-Communist Countries: An Analysis of the Attitudes toward the Single Currency", MPIfG Discussion Paper 08/1, Cologne: Max Plank Institute for the Study of Societies.

Aminzade, Ronald (1993). "Class Analysis, Politics, and French Labor History", in Lenard Berlanstein (ed.), Rethinking Labor History, Urbana and Chicago: University of Illinois Press: 90-113.

Andenæs, Mads and John Anthony Usher (2003). The Treaty of Nice and Beyond: Enlargement and Constitutional Reform, Portland OR: Hart.

Andrews David (2002). "The European Commission as an Agent for Monetary Integration", The European Union Center of California Working Paper 02-3.

Apel, Emmanuel (2003). Central Banking Systems Compared: the ECB, the Pre-Euro Bundesbank and the Federal Reserve System, London: Routledge.

Arestis, Philip, and Malcolm Sawyer (2011). "The Design Faults of the Economic and Monetary Union”, Journal of Contemporary European Studies, 19 (1): 21-32.

Arnold, Ivo J.M. (2001). "The Regional Effects of Monetary Policy in Europe", Journal of Economic Integration, 16(3): 399-420.

Aron, Raymond (1964). “Old Nations, new Europe”, Daedalus, 93 (1): 43-66.

Atkins, Ralph (2006). "Euro notes cash in to overtake dollar”, Financial Times, December 27.

Auer, Andreas (2005). "The constitutional scheme of federalism", Journal of European Public Policy, 12(3): 419-431.

Balassa, Bela (1961). The Theory of Economic Integration, Homewood IL: Richard Irwin ed.

Banducci, Susan, Jeffrey Karp, and Peter Loedel (2003). "The euro, economic interests and multi-level governance: Examining support for the common currency", European Journal of Political Research 42: 685-703. 
Barber, Tony (2010a). "Dinner on the edge of the abyss", Financial Times, October 11.

Barber, Tony (2010b). “Tall ambition, flawed foundations”, Financial Times, October 12.

Barber, Tony (2010c). "Bound towards a tense future", Financial Times, October 13.

Barber, Tony (2010d). "Merkel's Treaty tweak threatens EU credibility", Financial Times, October 28.

Barnes, Ian, and Pamela M. Barnes (1995). The Enlarged European Union, Harlow: Longman.

Beattle, Alan (2010). "Tough talk in Berlin scares investors over future rescues", Financial Times, December 1.

Begg, Iain (2008). "Economic Governance in an Enlarged Euro Area", European Economic Papers 311.

Beloff, Max (1974). "The Political Crisis of the European Nation-State", in Ionescu G. (ed.), Between Sovereignty and Integration, New York-Toronto: John Wiley \& Sons.

Bendnar, Jenna, John Ferejonh and Garrett Geoffrey (1997). "The Politics of European Federalism", in Dieter Schmiedtchen and Robert Cooter (eds). Constitutional Law and Economics of the European Union, Cheltenham: Edward Elgar.

Boesler, Matthew (2013). "There Are Only Two Real Threats to The US Dollar's Status as the International Reserve Currency", Business Insider, November 11 http://www.businessinsider.com/dollar-as-international-reserve-currency-2013-11 (accesses March 24, 2014).

Bordo, Michael David (1993). "The Bretton Woods International Monetary System: A Historical Overview", in Michael David Bordo and Eichengreen Barry (eds.), A Retrospective on the Bretton Woods System: Lessons for International Monetary Reform, Chicago: University of Chicago Press: 3-108.

Börzel, Tanja (2002). "Pace-Setting, Foot-Dragging, and Fence-Setting: Member States Responses to Europeanization”, Journal of Common Market Studies, 40(2): 193-214.

Börzel, Tanja (2006). The disparity of European integration: revisiting neofunctionalism in honour of Ernst B. Haas, New York: Routledge.

Börzel, Tanja and Madeleine O. Hosli (2003). "Brussels between Bern and Berlin: Comparative Federalism Meets the European Union”, Governance, 16(2): 179-202, 
Börzel, Tanja and Risse Thomas (2003). "Conceptualizing the Domestic Impact of Europe", in Kewin Featherstone and Claudio Radaelli (eds.), The Politics of Europeanization, Oxford: Oxford University Press: 57-82.

Börzel, Tanja and Thomas Risse (2000). "Who is Afraid of a European Federation? How to Constitutionalise a Multi-Level Governance System", Jean Monnet Working Paper No. $7 / 00$.

Bowie, Robert R. (1962). "The Project of Federating Europe", Arthur W. MacMahon (ed.), Federalism Mature and Emergent, New York: Russell \& Russell: 493-509.

Bradley, Michael and Mitu Gulati (2011). "Collective Action Clauses for the Eurozone: An Empirical Analysis", unpublished paper.

Braga De Macedo, Jorge and Barry Eichengreen (2001). "The European Payments Union: History and Implications for the Evolution of the International Financial Architecture", OECD Development Centre, Paris. URL: http://www.jbmacedo.com/oecd/triffin.html (access February 2012).

Brown, Douglas (2005). "Who's Afraid of Asymmetrical Federalism? A Summary Discussion”, Special Series on Asymmetric Federalism, Institute of Intergovernmental Relations, Kingston, Ontario: Queens University.

Brzinski, Joanne B. (1999). "Federalism and Compounded Representation: Key Concepts and Project Overview", Publius, 29 (1): 1-16.

Buiter Willem H. and Ebrahim Rahbari (2012). "The ECB as Lender of Last Resort for Sovereigns in the Euro Area", Discussion Paper No. 8974, London: Centre for Economic Policy Research.

Bulmer Simon and Claudio Radaelli (2004). “The Europeanization of National Policy”, Queen's Papers on Europeanization, 1/2004.

Bulmer, Simon (1998). "New institutionalism and the governance of the Single European Market", Journal of European Public Policy 5 (3): 365-386.

Buonanno Laurie and Neill Nugent (2013). Policies and Policy Processes of the European Union, Basingstoke: Palgrave Macmillan.

Burgess, Michael (2000). Federalism and European Union: The Building of Europe, 1950-2000, London: Routledge. 
Burgess, Michael (2006). "Federalism and Federation" in Cini, Michelle (ed.), European Union Politics, Oxford: Oxford University Press: 69-84.

Burgess, Michael (2006). Comparative Federalism, Theory and Practice, New York: Routledge.

Burgess, Michael and Alain-G. Gagnon (eds.) (1993). Comparative Federalism and Federation, Toronto: University of Toronto Press.

Büthe, Tim (2002). "Taking Temporality Seriously: Modeling History and the Use of Narratives as Evidence", American Political Science Review 96 (3): 481-493.

Cameron, David R. (1995). "Transnational relations and the development of European economic and monetary Union" in Risse-Kappen, Thomas (ed.) Bringing Transnational Relations Back In. Non-State Actors, Domestic Structures and International Institutions, Cambridge: Cambridge University Press.

Cappelletti, Mauro, Monica Seccombe and Joseph H.H. Weiler (eds.) (1986). Integration Through Law: Europe and the American Federal Experience, Berlin/New York: De Gruyter.

Carmassi Jacopo, Carmine Di Noia and Stefano Micossi (2012). "Banking Union: a federal model for the European Union with prompt corrective action", CEPS Policy Brief No. 282, CEPS: Brussels.

Castles, Francis G. (1998). Comparative Public Policy. Northampton, MA: Edward Edgar.

Christopher Sims (1999). "The Precarious Fiscal Foundations of EMU”, The Economist, 147 (4): 415-436.

Cienski, Jan, Chris Bryant (2010). "Exports to Germany help relieve crisis", Financial Times, November $30^{\text {th }}$.

Cini, Michelle and Nieves Pérez-Solórzano Borragán (2010). European Union Politics, Oxford University Press: Oxford.

Cobham, David and George Zis (eds.) (1999). From EMS to EMU: 1979 to 1999 and Beyond, London: Macmillan.

Coffey, Peter (2000). The Euro: an essential guide, London: Continuum Books.

Collier, David (2010). "Process Tracing and Causal Inference" in Brady Henry E. and David Collier (eds.), Rethinking Social Inquiry, Lanham, MD: Rowman \& Littlefield. 
Collier, David (2011). “Understanding Process Tracing”, Political Science and Politics, October: 823-830.

Commission of the EEC (1962). "Memorandum of the Commission on the action programme of the Community for the second stage" Brussels: Publishing Services of the European Communities.

Commission of the EEC (1969). "Commission memorandum to the Council on the co-ordination of economic policies and monetary co-operation within the Community", EEC Bulletin, n. 3.

Commission of the EEC (1985). "Completing the Internal Market: White Paper from the Commission to the European Council".

Committee for the Study of Economic and Monetary Union (1989). "Report on economic and monetary union in the European Community" (the Delors Report).

Committee of Governors of the Central Banks of the European Communities and European Monetary Co-operation fund (1985). "Texts concerning the European Monetary System", Luxembourg: s.n.

Congress of Europe (1948). "Resolutions", London-Paris: International Committee of the Movements for European Unity.

Constâncio, Vítor (2013). "Towards the Banking Union", speech given at the 2nd FIN-FSA Conference on EU Regulation and Supervision "Banking and Supervision under Transformation" Helsinki, February 12. European Central Bank website at http://www.ecb.europa.eu/press/key/date/2013/html/sp130212.en.html (accessed March 4, 2013).

Coombes, David (1970). Politics and Bureaucracy in the European Community, London: George Allen \& Unwin/PEP.

Cooper, Richard N. (1968). The Economics of Interdependence: Economic Policy in the Atlantic Community, New York: McGraw-Hill.

Cooper, Richard N. (1972). "Euro-dollars, reserve dollars and asymmetries in the international monetary system", in Journal of International Economics, 2 (4): 325-344.

Council and Commission (1970). "Report to the Council and the Commission on the realization by stages of economic and monetary union in the Community", Luxembourg http://ec.europa.eu/economy_finance/emu_history/documentation/chapter5/19701008en7 2realisationbystage.pdf (accessed July 2, 2013). 
Crawford, Malcolm (1996). One Money for Europe: The Economics and Politics of EMU, New York: St. Martin Press.

Crowley, Patrick M. (2001). "The Institutional Implications of EMU”, Journal of Common Market Studies, 39 (3): 385-404.

Crowley, Patrick M. (2006). “Is there a Logical Integration Sequence After EMU?”, Journal of Economic Integration, 21(1): 1-20.

Dandashly, Assem and Amy Verdun (2009a). A Road with Multiple Lanes: The Journeys of the Czech Republic, Poland and Slovenia towards Euro Adoption", paper presented at the Eleventh Biennial International EUSA Conference, Los Angeles, California, April 23-25, 2009.

Dandashly, Assem and Amy Verdun (2009b). "The Domestic Politics of Euro Adoption in the Czech Republic, Hungary and Poland", paper prepared for presentation at the Conference The Evolution of Integration in Europe, 20 Years after the Fall of the Berlin Wall, Viessmann Academy, Germany, October 12-14, 2009.

De Grauwe, Paul (2005). Economics of monetary union, Oxford: Oxford University Press.

de Lattre, André (1999). Servir Aux Finances, Paris: comité pour l'Historie Économique et Financière de la France.

Deroose Servaas, Dermot Hodson and Joost Kuhlmann (2004). "Economic Governance in the EU: Lessons from the First Five Years of EMU", Paper presented at the UACES conference, Birmingham, September 2004.

Deutsch, Karl (1974). "Between Sovereignty and Integration: Conclusion", in Ghita Ionescu (ed). Between Sovereignty and Integration, New York-Toronto: John Wiley \& Sons.

Diebolt, William (1962). "The Relevance of Federalism to Western European Economic Integration", in Arthur W. MacMahon (ed.), Federalism Mature and Emergent, New York: Russell \& Russell: 433-458.

Dinan, Desmond (2005). "Ever Closer Union”, Rienner: Boulder, p. 77-79.

Dinan, Desmond (2007). "Fifty Years of European Integration: A Remarkable Achievement", Fordham International Law Journal, 31 (7): 1117-1142.

Dinmore, Guy (2010). "Italian coalition's woes fuel fears of contagion”, Financial Times, November 30. 
Dosenrode, Søren (ed.) (2007). Approaching the European Federation?, Burlington, VT: Ashgate.

Draghi, Mario (2012). "Verbatim of the remarks at the Global Investment Conference in London", July 26. European Central Bank website at http://www.ecb.int/press/key/date/2012/html/sp120726.en.html (accessed March 15, 2013).

Dyson Kenneth (2002b). "The Euro-Zone in a Political and Historical Perspective", in Søren Dosenrode (ed.), Political Aspects of the economic and Monetary Union, Aldershot: Ashgate: 17-40.

Dyson, Kenneth (1994). Elusive Union, the process of Economic and Monetary Union in Europe, Longman, London and New York.

Dyson, Kenneth (2000a). "EMU as Europeanization: Convergence, Diversity and Contingency", Journal of Common Market Studies, 38(4): 645-666.

Dyson, Kenneth (2000b). The Politics of the Euro-Zone, Oxford: Oxford University Press.

Dyson, Kenneth (2002a). "EMU as Europeanization: Convergence, Diversity, and Contingency", in Amy Verdun (ed). The Euro: European Integration Theory and Economic and Monetary Union, Lanham MD: Rowman \& Littlefield: 91-108.

Dyson, Kenneth (2002c). European States and the Euro: Europeanization, Variation and Convergence, Oxford: Oxford Press University.

Dyson, Kenneth (2007a). Enlarging the Euro Area: External Empowerment and Domestic Transformation in East Central Europe, Oxford: Oxford University Press.

Dyson, Kenneth (2007b). "Euro Area entry in East-Central Europe: Paradoxical Europeanisation and Clustered convergence", West European Politics, 30(3): 417-442.

Dyson, Kenneth (2008). The Euro at Ten: Convergence, Europeanization, and State Power, Oxford University Press: Oxford.

Dyson, Kenneth and Kevin Featherstone (1996). "Italy and EMU as a "Vincolo Esterno": Empowering the technocrats, Transforming the State", South European Society and Politics 1(2): 272-99.

Dyson, Kenneth and Kevin Featherstone (1999). The Road to Maastricht: Negotiating Economic and Monetary Union, Oxford: Oxford University Press. 
Dyson, Kenneth and Martin Marcussen (2010). "Transverse Integration in European Economic Governance: Between Unitary and Differentiated Integration", Journal of European Integration, 32 (1): 17-39.

Dobson, Hugo et. al. (2001). Japan's International Relations: Politics, Economics and Security, London: Routledge.

Duina, Francesco and Paulette Kurzer (2004). "Smoke in Your Eyes: The Struggle Over Tobacco Control in the European Union", Journal of European Public Policy 11(1): 57-77.

Elazar, J. Daniel (1987). Exploring Federalism, Tuscaloosa, AL: University of Alabama Press.

Elster, Jon, Claus Offe and Ulrich K. Preuss (1998). Institutional Design in Post-Communist Societies: Rebuilding the Ship at Sea, Cambridge: Cambridge University press.

Enrich, David, and Charles Forelle (2010). "Irish Grasp at EU, IMF Lifeline", The Wall Street Journal, November 19.

Europe's Single Debt Zone (2010). Wall Street Journal, November 30.

European Central Bank (2010). "The ECB's Response to the Financial Crisis", ECB Monthly Bulletin, October, European Central Bank Publications: Frankfurt.

European Central Bank (2011). "The European Stability Mechanism", ECB Monthly Bulletin, July 2011, European Central Bank Publications: Frankfurt.

European Central Bank (2012a). "A Fiscal Compact for a Stronger Economic and Monetary Union", ECB Monthly Bulletin May 2012, European Central Bank Publications: Frankfurt.

European Central Bank (2012b). "Technical features of Outright Monetary Transactions" http://www.ecb.int/press/pr/date/2012/html/pr120906_1.en.html (accessed April 25, 2013).

European Central Bank (2014a). "Statistical Data Warehouse", http://sdw.ecb.europa.eu/home.do?chart=t1.5 (accessed March 19, 2014).

European Central Bank (2014b). "Table 2: Euro banknotes and coins statistics”, February 2014, https://stats.ecb.europa.eu/stats/download/bkn_notes_val/bkn_notes_val/bkn_notes_val.p df (accessed April 9, 2014).

European Commission (2011a). "Proposal for a Regulation of the European Parliament and of the Council on the Strengthening of Economic and Budgetary Surveillance of Member 
States Experiencing or Threatened with Serious Difficulties with Respect to their Financial Stability in The Euro Area”, Brussels, COM (2011) 819 final.

European Commission (2011b). "EU Economic governance "Six-Pack" enters into force", Commission Press Release, 12 December. http://europa.eu/rapid/pressReleasesAction.do?reference=MEMO/11/898 (accessed April 12, 2013).

European Commission (2011c). "Economic governance: Commission proposes two new Regulations to further strengthen budgetary surveillance in the euro area", http://europa.eu/rapid/pressReleasesAction.do?reference=MEMO/11/822 (accessed May 20, 2012).

European Commission (2012a). "Economic and Financial Affairs", http://ec.europa.eu/economy_finance/focuson/crisis/q_and_a_2_en.htm (accessed May $\left.8^{\text {th }}, 2012\right)$.

European Commission (2012b). "Balance of Payments Assistance", http://ec.europa.eu/economy_finance/eu_borrower/balance_of_payments/index_en.htm (accessed May $8^{\text {th }}, 2012$ ).

European Commission (2012c). "The Greek Loan Facility", http://ec.europa.eu/economy_finance/eu_borrower/greek_loan_facility/index_en.htm (accessed May $8^{\text {th }}, 2012$ ).

European Commission (2012d). "Stability and Growth Pact", http://ec.europa.eu/economy_finance/economic_governance/sgp/index_en.htm (accessed May 19, 2012).

European Commission (2012e). “A Roadmap towards a Banking Union”, Brussels.

European Commission (2012f). "Commission proposals for a single supervisory mechanism", http://ec.europa.eu/internal_market/finances/banking-union/index_en.htm (accessed March 17, 2013).

European Commission (2013a). "Links to other currencies", http://ec.europa.eu/economy_finance/euro/world/other_currencies/index_en.htm (accessed March 18, 2014).

European Commission (2013b). "What is ERM II?", http://ec.europa.eu/economy finance/euro/adoption/erm2/index_en.htm (accessed May 1, 2014). 
European Council (1978). "Resolution of the European Council of 5 December 1978 on the establishment of the European Monetary System (EMS) and related matters".

European Council (2011a). "Conclusions of the European Council”, 24/25 March 2011.

European Council (2013). ""Fiscal compact" entered into force on 1 January 2013", http://www.european-council.europa.eu/home-page/highlights/fiscal-compact-entersinto-force-on-1-january-2013?lang=en (accessed April 25, 2013).

European Financial Stabilisation Mechanism (2012). official website, http://ec.europa.eu/economy_finance/eu_borrower/efsm/index_en.htm (accessed May $7^{\text {th }}$, 2012).

European Financial Stability Mechanism (2013). "Ireland's exit", http://www.efsf.europa.eu/about/operations/ireland/index.htm (accessed Feb 20th, 2014).

European Stabilisation Actions "Homepage", http://ec.europa.eu/economy_finance/eu_borrower/european_stabilisation_actions/index_ en.htm (accessed May $7^{\text {th }}, 2012$ ).

European Union (2010). "Division of competences within the European Union", http://europa.eu/legislation_summaries/institutional_affairs/treaties/lisbon_treaty/ai0020_ en.htm (accessed February 24, 2014).

European Union (2011). "Community and intergovernmental methods", http://europa.eu/legislation_summaries/glossary/community_intergovernmental_methods _en.htm (accessed April 2, 2014).

European Union (2012). "The Institutions of the Union", http://europa.eu/scadplus/constitution/europeancouncil_en.htm (accessed April 17, 2014).

European Union (2013). "Economic and Financial Committee", http://europa.eu/efc/index_en.htm (accessed April 13, 2014).

Eurostat (2012). "Real GDP growth rate", http://epp.eurostat.ec.europa.eu/tgm/table.do?tab=table\&init=1\&plugin=1\&language=en $\underline{\text { \&pcode }=\text { tsieb020 }}\left(\right.$ accessed May $\left.4^{\text {th }}, 2012\right)$.

Eurostat (2014). "News Release Euro Indicators: Flash estimate for the fourth quarter of 2013", 23/2014, February 14. http://epp.eurostat.ec.europa.eu/cache/ITY_PUBLIC/2-14022014AP/EN/2-14022014-AP-EN.PDF (accessed March 23, 2014). 
Evans-Pritchard, Ambrose (2012). "Greek debt accord hostage to political passions", The Telegraph, Feb 21.

Fabbrini, S. (2008). "The Constitutionalization of a Compound Democracy: Comparing the European Union with the American Experience", conWEB webpapers on Constitutionalism and Governance Beyond the State, 3.

Fabbrini, Sergio (2002). "The Puzzle of the Compound Republic. The EU, US and Implications of Federalization", EUI-RSCAS Working Paper No. 2002/27, European University Institute, Florence.

Fabbrini, Sergio (2013a). "Intergovernmentalism and Its Limits. Assessing the European Union's Answer to the Euro Crisis”, Comparative Political Studies, 46 (9): 1003-1029.

Fabbrini, Sergio (2013b). "The Outcomes of Intergovernmentalism: The Euro Crisis and the Transformation of the European Union", in Bruno de Witte, Adrienne Heritier and Alexander H. Trechsel (eds.), The Euro Crisis and the State of European Democracy, Florence, European University Institute, Robert Schuman Centre for Advanced Studies, The European Union Democracy Observatory E-book: 101-28, www.eudo.eu.

Fabbrini, Sergio (ed.) (2005). Democracy and Federalism in the European Union and the United States: Exploring post-national Governance, Routledge, London/New York.

Falkner, Gerda et. Al (2005). Complying with Europe: EU Harmonisation and Soft Law in the Member States, Cambridge: Cambridge University Press.

Falleti, Tulia (2006). "Theory-Guided Process-Tracing: Something Old, Something New", Newsletter of the Organized Section in Comparative Politics of the APSA, 17 (1): 9-14.

Featherstone, Kevin (1999). "The Political Dynamics of the Economic and Monetary Union", in Laura Cram et al. (eds.), Developments in the European Union, New York: St. Martin Press.

Federal Reserve Bank (2014). "Money Stock Measures Statistical Release", April 3, http://www.federalreserve.gov/Releases/h6/current/default.htm (accessed April 13, 2014).

Feldstein, Martin (2012). "The failure of the euro", Foreign Affairs, January/February.

Forelle, Charles and Marcus Walker (2010). "Germany Stalls Bid to Expand EU Rescue Funds", The Wall Street Journal, December 7. 
Forsyth, Murray (1981). Unions of States: The Theory and Practice of Confederation, Leicester: Leicester University Press.

Fratianni, Michele and Jürgen von Hagen (1992). The European Monetary System and European Monetary Union, Boulder, CO: Westview Press.

Friedrich, Carl J. (1962). "Federal Constitutional Theory and Emergent Proposals", in Arthur W. MacMahon (ed.), Federalism Mature and Emergent, New York: Russell \& Russell: 510:534.

Galgóczi, Béla, Janine Leschke, and Andrew Watt (eds.) (2012). EU Labour Migration in Troubled Times, Burlington VT: Asghate.

George Alexander L. and Andrew Bennett (2005). Case Studies and Theory Development in the Social Sciences. Cambridge, MA and London, England: MIT Press.

George Alexander L. and Timothy J. McKeown (1985). "Case Studies and Theories of Organizational Decision Making", Advances in Information Processing in Organizations 2: $21-58$.

George, Alexander L. (1979). "Case studies and theory development", in Paul Lauren (ed.), Diplomacy: New approaches in theory, history, and policy, New York: Free Press: 43-68.

George, Alexander L. and Richard Smoke (1974). Deterrence in American foreign policy, New York: Columbia University Press.

Glencross, Andrew (2013). "The EU Response to the Eurozone Crisis: Democratic Contestation and the New Fault Lines in European Integration", Europa-Kolleg Hamburg, Institute for European Integration, Discussion Paper No 3/13, http://www.europa-kolleg-hamburg.de.

Goff, Sharlene and Patrick Jenkins (2010). "Ireland remains on a tightrope", Financial Times, November 30 .

Gray, Virginia (1973). "Innovation in the States: A Diffusion Study" American Political Science Review, 67: 1174-85.

Gray, Virginia (1994). "Competition, Emulation, Policy Innovation”, in Lawrence C. Dodd and Calvin Jillson (eds.), New Perspectives on American Politics, Washington: CQ Press: 230-48.

Green Cowles, Maria James Caporaso, and Risse Thomas (eds.) (2001). Transforming Europe: Europeanization and Domestic Change, Ithaca and London: Cornell University Press. 
Green Cowles, Maria, James Caporaso and Risse Thomas (2001). "Europeanization and Domestic Change: Introduction”, in Maria Green Cowles, James Caporaso, and Thomas Risse (eds.) Transforming Europe, Cornell: Cornell University Press: 1-20.

Grodzins, Morton (1966). The American System: A New View of Government in the United States, Chicago: Rand McNally.

Grodzins, Morton and Elazar, Daniel (1984). The American system: A new view of Government in the United States, New Brunswick NJ: Transaction Books.

Gros, Daniel and Cinzia Alcidi (2011). "Adjustment Difficulties and Debt Overhangs in the Eurozone Periphery", LLEE Working Document 92, Centre for European Policy Studies (CEPS).

Gros, Daniel, and Niels Thygesen (1999). European Monetary Integration, London: Longman.

Gruber, Lloyd (2000). Ruling the World: Power Politics and the Rise of Supranational Institutions, London: Longman.

Haas, Ernst (1958). The Uniting of Europe: Political, Social and Economic Forces 1950-1957, London: Stevens.

Haas, Ernst (1970). "The Study of Regional Integration: Reflections on the Joy and Anguish of Pretheorizing", International Organizations 24: 607-644.

Haas, Ernst (1971). "The Study of Regional Integration: Reflections on the joy and the anguish of Pretheorizing", in Leon N. Lindberg and Scheingold Stuart A. (eds.). Regional Integration Theories and Research, Harvard: Harvard University Press.

Haas, Peter M. (1992) "Introduction: epistemic communities and international policy coordination”, International Organization, 46(1): 1-35.

Habermas, Jürgen (2012). The Crisis of the European Union: A Response, Cambridge: Polity Books.

Haidar, Jamal Ibrahim (2012). "Sovereign Credit Risk in the Eurozone", World Economics, 13(1): 123-136.

Hall, Ben, Quentin Peel, and Joshua Chaffin (2010). "France and Germany Agree to Mechanism for Future Crises", Financial Times, November 28.

Hall, Peter A. (2003). "Aligning Ontology and Methodology in Comparative Politics." in James Mahoney and Dietrich Rueschemeyer (eds.), Comparative Historical Analysis in the Social Sciences, New York: Cambridge:373-404. 
Hannon, Paul (2007). "Euro Fatigue Takes Hold”, Wall Street Journal, August 7.

Hendrix, Gisela and Annette Morgan (2001). The Franco-German axis in European integration, Northampton: Edward Elgar.

Héritier, Adrienne and Christopher Knill (2001). "Differential Responses to European Policies: A Comparison", in Adrienne Héritier et al. (eds). Differential Europe: The European Union Impact on National Policymaking: New Opportunities and Restrictions for Policymaking in the Member States, Lanham MD: Rowman \& Littlefield: 257-294.

Hitchcock William I. (2010). "The Marshall Plan and the creation of the West" in Melvyn P. Leffler and Odd Arne Westad (eds.), The Cambridge History of the Cold War, Cambridge: Cambridge University Press.

Hix, Simon (2005). The Political System of the European Union, New York: Palgrave Macmillan.

Hix, Simon and Høyland, Bjorn (2011). The Political System of the European Union, Houndmills and New York: Palgrave Macmillan.

Hix, Simon, and Gérard Roland (2007). "Why the Franco-German Plan would Institutionalise 'Cohabitation' for Europe", Foreign Policy Centre, http://fpc.org.uk/articles/201 (accessed March 18, 2014).

Hodson, Dermot (2011). Governing the Euro Area in Good Times and Bad, Oxford: Oxford University Press.

Hoffmann, Stanley (1965). "The European Process at Atlantic Cross Purposes", Journal of Common Market Studies, vol. 3, 85-101.

Hoffmann, Stanley (1995). The European Sisyphus: Essays on Europe 1964 - 1994, Oxford: Oxford University Press.

Hogan, Michael J. (1987). The Marshall Plan. America, Britain and the Reconstruction of Western Europe, 1947-1952, Cambridge: Cambridge University Press.

Holzinger, Katharina and Christopher Knill (2000). “A Constitution for the European Federation: A Steady Development of Existing Achievements", Harvard Jean Monnet Working Paper, 7/00.

Hooghe, Liesbet and Gary Marks (2001). Multi-level Governance and European Integration, Lanham, MD: Rowman and Littlefield. 
Hooghe, Liesbet and Gary Marks (2003). "Unraveling the Central State, but how? Types of Multi-Level Governance”, American Political Science Review, 97: 233-43.

Hosli, Madeleine (2000). "The Creation of the European Economic and Monetary Union (EMU): Intergovernmental negotiations and two-level games", Journal of European Public Policy, 7(5): 744-66.

Howarth, David (2002) “The French State in the Euro-Zone: 'Modernization' and Legitimizing Dirigisme" in Kenneth Dyson (ed.), European States and Euro: Europeanization, Variation, and Convergence, Oxford: Oxford University Press: 145-172.

Hueglin, Thomas O. (1995). "New Wine in Old Bottles? Federalism and Nation States in Twenty-First Century: A Conceptual Overview", in Sylvia Ostry et al. (eds.), Rethinking Federalism: Citizens, Market, and Governments in a Changing World, Vancouver: UBC Press: 203-23.

Hueglin, Thomas O. (2000). "From Constitutional to Treaty Federalism: A Comparative Perspective", Publius, 30:137-53.

Hueglin, Thomas O. and Alan Fenna (2006). Comparative Federalism: a Systematic Inquiry, Toronto: Broadview Press.

Huelshoff, Michael G. (1994). "Domestic Politics and Dynamic Issue Linkages - A Reformulation of Integration Theory”, International Studies Quarterly, 38 (2): 255-279.

Ionescu, Ghita (1974). "Between Sovereignty and Integration: an Introduction", in Ghita Ionescu (ed). Between Sovereignty and Integration, New York-Toronto: John Wiley \& Sons: 724.

Jabko, Nicolas (2006). "The Politics of Central Banking in the United States and the European Union", in Anand Menon and Martin A. Schain (eds.), Comparative Federalism: The European Union and the United States in Comparative Perspective, Oxford: Oxford University Press: 275-291.

Jabko, Nicolas (2013). "The Divided Sovereignty of the Eurozone", in Philipp Genschel and Markus Jachtenfuchs (eds.), Beyond the Regulatory Polity? The European Integration of Core State Powers, Oxford: Oxford University Press:124-142.

Jenkins, Patrick (2010). "Bail-out document runs dry on tackling liquidity issue", Financial Times, November 30.

Johnson, Harry G. (1973). "The Exchange Rate Question for a United Europe: Internal Flexibility and External Rigidity versus External Flexibility and Internal Rigidity", in 
Alexander K. Swoboda (ed.), Europe and the Evolution of the International Monetary System, Genève: Institut Universitaire de Hautes Etudes Internationales:81-91.

Johnson, Juliet (2008). "The remains of conditionality: the faltering enlargement of the euro zone”, Journal of European Public Policy, 15 (6): 826-41.

Jones, Erik (2002). The Politics of Economic and Monetary Union: Integration and Idiosyncrasy, Boulder: Rowman \& Littlefield.

Juncker, Jean-Claude Juncker, and Giulio Tremonti (2010). "E-bonds would end the crisis", Financial Times, December 5.

Kaelberer, Matthias (2004). "The Euro and European Identity: Symbols, Power and the Politics of European Monetary Union”, Review of International Studies, 30:161-178.

Kaltenthaler, Karl (2006). Policymaking in the European Central Bank, Lanham, MD: Rowman and Littlefield.

Kelemen, R. Daniel (2004). The Rules of Federalism, Institutions and Regulatory Politics in the EU and Beyond, Harvard University Press: Harvard.

Kenen, P. (1995). Economic and Monetary Union in Europe, Cambridge: Cambridge University Press.

Keohane, R. O. (1989). International Institutions and State Power: Essays on International Relations Theory, Boulder, CO: Westview.

King, Preston (1982). Federalism and Federation, London and Canberra: Croom Helm.

Kingdon, John W. (1984). Agendas, alternatives and public policies, Boston: Little, Brown \& Co.

Kölliker, Alkuin (2006). Flexibility and European Unification, the Logic of Differentiated Integration, Lanham: Rowman and Littlefield.

Kostadinova, Petia (2009). "The Puzzle of Single Currency (Non) Adoption in the New Member States", paper presented at APSA 2009 Toronto Meeting.

Kreppel, Amie (2002). The European Parliament and Supranational Party System: a study in institutional development, Cambridge: Cambridge University Press.

Krugman, Paul (2012). “Europe's Economic Suicide”, New York Times, April 15, 2012. 
Kruse, D.C. (1980). Monetary integration in Western Europe: EMU, EMS and Beyond, London and Boston: Butterworks.

Kudrna, Zdenek (2012). "Cross-Border Resolution of Failed Banks in the European Union after the Crisis: Business as Usual”, Journal of Common Market Studies, 50 (2): 283-299.

Kühnhardt, Ludger (2009). "The Fall of the Berlin Wall and European Integration", http://www.kas.de/upload/Publikationen/Panorama/2009/1/kuehnhardt.pdf $\quad$ (accessed May 1, 2014).

Künhhardt, Ludger (2013). Crises in European integration: challenge and response, 1945-2005, New York/Oxford: Berghahn Books.

Kunstein, Tobias and Wolfgang Wessels (2013). "The New Governance of the Economic and Monetary Union: Adapted Institutions and Innovative Instruments", IAI Working Papers 13(2).

Inglehart, Ronald (1971), "Public Opinion and European Integration", in Lindberg, Leon N., Scheingold, Stuart A. (eds.), Regional Integration: Theory and Research, Cambridge: Harvard University Press: 160-191.

La Politique Monétaire dans le cadre du Marché Commun (1962). ECB Archives.

Ladrech, Robert (1994). "Europeanization of Domestic Policies and Institutions: The Case of France", in Journal of Common Market Studies, 32 (1): 69-88.

Lannoo, Karel (2011). "EU Federalism in Crisis”, CEPS Policy Brief 259, CEPS: Brussels.

Leibfried Stephan, and Paul Pierson (1995). European Social Policy: Between Fragmentation and Integration, Washington, DC: The Brookings Institution.

Leonardi, Robert and Raffaella Nanetti (2007). "Thinking about Federal Systems in the 21st Century in Light of the European Experience with "Operational" Federalism", in Michael A. Pagano and Robert Leonardi (eds.), The Dynamics of Federalism in National and Supranational Political Systems, New York: Palgrave Macmillan: 288-304.

Lieberman, Sima (1992). The Long Road to a European Monetary Union, London: University of America Press.

Lindberg, Leon N. (1963). The Political Dynamics of European Integration, Stanford, CA: Princeton University Press.

Lindberg, Leon N. and Scheingold, S. (1971). Regional Integration: Theory and Research, Cambridge, MA: Harvard University Press. 
Loedel, Peter H. (1995). "The Franco-German monetary partnership and the future of European Monetary Union", paper presented at the European Union Studies Association Conference, May 11-14, Charleston, South Carolina.

Loedel, Peter H. (2002). "Multilevel Governance and the Independence of the European Central Bank", in Amy Verdun (ed). The Euro: European Integration Theory and Economic and Monetary Union, Lanham MD: Rowman \& Littlefield: 125-144.

Louis, Jean-Victor (1990). "From EMS to monetary union", Luxembourg: Office for Official Publications of the European Communities.

Ludlow Peter (1982). The making of the European Monetary System: a case study of the politics of the European Community, London-Boston: Butterworth.

Luxemburgensis (1974). "The Emergence of a European Sovereignty", in Ghita Ionescu (ed.), Between Sovereignty and Integration, New York-Toronto: John Wiley \& Sons: 118-134.

MacMahon Arthur W. (1962). Federalism Mature and Emergent, New York: Russell \& Russell.

Maes Ivo (2006). "The Ascent of the European Commission as an Actor in the Monetary Integration Process in the 1960s", Scottish Journal of Political Economy, 53 (2): 222-241.

Maes Ivo (2007). Half a Century of European Financial Integration. From the Rome Treaty to the 21st Century. Brussels: Mercatorfonds.

Majone, Giandomenico (1996). Regulating Europe, London and New York: Routledge.

Majone, Giandomenico (1998). "Europe's 'Democratic Deficit': The Question of Standards", European Law Journal, 4 (1): 5-28.

Majone, Giandomenico (2004). Dilemmas of European Integration. The Ambiguities and Pitfalls of Integration by Stealth, Oxford University Press: Oxford.

Making eurozone safe from failure (2010). Financial Times, October 12.

Marks, Gary (1993). "Structural Policy and Multilevel Governance in the EC", in Alan Cafruny and Glenda Rosenthal (eds.), The State of the European Community, New York: Lynne Rienner, 391-410.

Masson, Paul R. et al. (1997) EMU and the International Monetary System, Washington.

Maurer, Andreas (2013). "From EMU to DEMU: The Democratic Legitimacy of the EU and the European Parliament", IAI Working Papers 13-11. 
McKay, David (1999), Federalism and European Union, Oxford: Oxford University Press.

McKay, David (2001), Designing Europe: Comparative Lessons from the Federal Experience, Oxford: Oxford University Press.

McNamara, Kathleen R. (1998). The Currency of Ideas: Monetary Politics in Europe, Ithaca: Cornell University Press.

McNamara, Kathleen R. (2003). "Towards a Federal Europe? The Euro and Institutional Change in Historical Perspective", in Tania Börzel and Rachel A. Cichowski (eds.), The State of the European Union, Vol. 6, Oxford: Oxford University Press: 253-269.

McNamara, Kathleen R. and Sophie Meunier (2002). 'Between National Sovereignty and International Power: The External Voice of the Euro'. International Affairs, 78 (4): 84968.

Meade, James (1955). Trade and Welfare, Oxford: Oxford University Press.

Menon, Anand, Schain, Martin (eds.) (2006). Comparative Federalism: The European Union and the United States in Comparative Perspective, Oxford University Press, Oxford.

Miles, Lee (forthcoming). Economic and Monetary Union and Euro-Outsiders: the Fusion Perspective, New York: Routledge.

Minder Raphael, Nicholas Kulish, and Paul Geitner (2012). "Spain to Accept Rescue From Europe for its Ailing Banks", New York Times, June 9.

Monetary Committee of the Commission of the European Community (1994). "Compendium of Community Monetary Texts", Office for Official Publications of the European Communities, Luxembourg.

Monetary Committee of the European Communities (1979). "Compendium of Community Monetary Texts", Office for Official Publications of the European Communities, Luxembourg.

Monetary Committee of the European Communities (1989). "Compendium of Community Monetary Texts", Office for Official Publications of the European Communities, Luxembourg.

Moravcsik, Andrew (1998). The Choice for Europe: Social Purpose and State Power from Messina to Maastricht, London: UCL press.

Moravcsik, Andrew (2012). "Europe After the Crisis. How to Sustain a Common Currency", Foreign Affairs, 91 (3): 53-68. 
Moravcsik, Andrew (2013). Lecture by Andrew Moravcsik at 13th Biennial Conference of the European Union Studies Association in Baltimore, May 9, 2013.

Morison, Samuel Eliot and Henry Steele Commager (1962). The Growth of the American Republic, Oxford: Oxford University Press.

Mulhearn Chris, and Howard R. Vane, (2008). The Euro: Its Origins, Development and Prospects, Edward Elgar.

Müller-Peters, Anke (1998). "The significance of national pride and national identity to the attitude toward the single European currency: a Europe-wide comparison", Journal of Economic Psychology, 19 (6): 701-719.

Mundell, R. A. (1961). "A Theory of Optimum Currency Areas", American Economic Review, 51 (4): 657-665.

Mundell, Robert A. and Armand Clesse (2000). The Euro as a Stabilizer in the International Economic System, Dordrecht: Springer.

Musgrave, Richard M. (1959). The Theory of Public Finance, New York: McGraw-Hill.

National Commission on the Causes of the Financial and Economic Crisis in the United States (2010). “The Financial Crisis, Inquiry Report”, U.S. Government Printing Office.

Nicolaidis, Kalypso (2006). "Paradise Lost? The new European Constitution in the Shadow of Federalism", in Halberstam, Daniel and Miguel Maduro (eds.), The Constitutional Challenge in Europe and America: People, Power, and Politics, Cambridge University Press: Cambridge.

Nicolaidis, Kalypso and Robert Howse (2001). The Federal Vision: Legitimacy and Levels of Governance in the United States and the European Union, Oxford: Oxford University Press:

Niemann, Arne (2006). Explaining Decisions in the European Union, Cambridge: Cambridge University Press.

Niemann, Arne and Demosthenes Ioannou (2013). "European economic integration in times of crisis: the case of neofuncionalism", paper presented at the 13th Biennial Conference of the European Union Studies Association in Baltimore, May 9-11, 2013.

Nixon, Simon (2010). "Cutting the Cord Between Euro Banks and Sovereigns", The Wall Street Journal, December 7. 
Nye, Joseph (1970). "Comparing Common Markets: A Revised Neo-Functionalist Model", International Organization, 24: 796-835.

O estado a que o Estado chegou (2011). Diário de Notícias, March 2.

O’Neall Michael (1996). The Politics of European Integration, New York: Routledge.

Oakley, David and Richard Milne (2010). "Eurozone Bail-out plan fails to lift bond market", Financial Times, Novembre 30.

Oates, Wallace E. (1972). Fiscal Federalism, New York: Harcourt Brace.

Obinger, Herbert, Stephan Leibfried and Francis G. Castles (2005). Federalism and the Welfare State. New World and European Experiences, Cambridge: Cambridge University Press.

Official Journal of European Communities (1964). April 22.

Ohmae, Kenichi (1990). The Borderless World, London: Collins.

Ohmae, Kenichi (1995). The End of the Nation State, Glencoe: Free Press.

Ostrom, Vincent (1987). "The Political Theory of a Compound Republic. Designing the American Experiment”, Lincoln: University of Nebraska Press.

Pact for the Euro, What's in a name? (2011). The Economist, March 25.

Padoa-Schioppa, Tommaso (1990). Financial and Monetary Integration in Europe: 1990, 1992 and Beyond, New York and London: Group of Thirty.

Padoa-Schioppa, Tommaso (2000). The Road to Monetary Union in Europe, Oxford: Oxford University Press.

Pagano, Michael A. and Robert Leonardi (eds.) (2007). The Dynamics of Federalism in National and Supranational Political Systems, New York: Palgrave Macmillan.

Pagoulatos, George and Lucia Quaglia (2013). "Domestic coalitions and the sovereign debt crisis in Southern Europe", paper presented at the 13th Biennial Conference of the European Union Studies Association in Baltimore, May 9-11, 2013.

Perez, Santiago, Brian Blackstone and Stephen Fidler (2010). "Spain, Italy Seek Action", The Wall Street Journal, December 2.

Persson, Torsten and Guido Tabellini (1996). "Federal Fiscal Constitutions: Risk Sharing and Redistribution”. Journal of Political Economy, 104 (5): 979-1009. 
Piattoni, Simona (2010). The Theory of Multi-Level Governance: Conceptual, Empirical, and Normative Challenges, Oxford University Press: Oxford.

Pignal, Stanley (2010). "Brussels highlights growth chasm”, Financial Times, November 30.

Pinder, John (1991). European Community: The Building of a Union, Oxford, Oxford University Press.

Pinder, John (1998). The Building of the European Union, Oxford, Oxford University Press.

Poland and the Euro, Augustinian Delay (2012). The Economist, August 18.

Pollack, Mark (1997). "Delegation, Agency and Agenda Setting in the European Community," International Organizations, 51: 99-134.

Pollack, Mark (2005). “Theorizing EU-Policy Making”, in Wallace, William, Helen Wallace and Mark Pollack (eds.), Policy-making in the European Union, Oxford: Oxford University Press: $13-48$.

Pond, Elizabeth (1999). "The Rebirth of Europe", in Elizabeth Pond (ed.), Present at the Second Creation: European Monetary Union, Washington, D.C: Brookings Press: 77-104.

Puchala, Donald J. (1971). "Of Blind Men, Elephants and International Integration", Journal of Common Market Studies, 10 (3): 267-284.

Puetter, Uwe (2012). "Europe's Deliberative Intergovernmentalism. The Role of the Council and European Council in EU Economic Governance", Journal of European Public Policy, 19 (2): 161-78.

Quiggin, John (2010). "Why austerity and 'zombie' ideas are bound to fail”, Financial Times, November 30 .

Radaelli, Claudio (2003). "The Europeanization of Public Policy", in Kevin Featherstone and Claudio Radaelli (eds.), The Politics of Europeanization, Oxford: Oxford University Press:27-46.

Radaelli, Claudio, Claire Dunlop and Jonathan Kamkhaji (2013). "Why the EU Does Not Learn: Cases from the Eurozone Crisis", paper presented at the 13th Biennial Conference of the European Union Studies Association in Baltimore, May 9-11, 2013.

Rhodes, Carolyn and Sonia Mazey (eds.) (1995). Building a European Polity?, Boulder CO: Lynne Rienner. 
Riker, William H. (1975). "Federalism", in Fred I. Greenstein and Nelson W. Polsby (eds.) Handbook of Political Science, 5: Governmental Institutions and Processes, Reading MA: Addison-Wesley: 93-172.

Risse, Thomas, Maria Green Cowles, and James Caporaso (2000). "Europeanization and Domestic Change: Introduction", in Maria Green Cowles, James Caporaso, and Thomas Risse (eds.) Transforming Europe, Cornell: Cornell University Press: 1-20.

Risse-Kappen, Thomas (1996). "Exploring the Nature of The Beast: International Relations Theory and Comparative Policy Analysis Meet the European Union", Journal of Common Market Studies, 34(1): 54-81.

Rosamond, Ben (2000). Theories of European Integration, New York, St. Martin Press.

Rose, Andrew K. (1999). "One Money, One Market: Estimating the Effect of Common Currencies on Trade", National Bureau of Economic Research, Working Paper 7432 December: Chicago.

Rosenstiel, Francis (1963). "Reflections on The Notion of 'Supranationality", Journal of Common Market Studies, 2, (2): 127-139.

Rosenthal, Glenda G. (1975). The men Behind the Decisions: Cases in European Policy-Making, Lexington, Mass., Toronto and London, Lexington Books.

Ruback, Timothy J. (2010) “'Let Me Tell the Story Straight On’: Middlemarch, Process-Tracing Methods and the Politics of Narrative", The British Journal of Politics \& International Relations, 12 (4): 477-497.

Sandholtz, Wayne and Alec Stone Sweet (1998). European integration and supranational governance, Oxford: Oxford University Press.

Savage, James D. (2007). Making the EMU: The Politics of Budgetary Surveillance and The Enforcement of Maastricht, Oxford: Oxford University Press.

Savage, James D. and Amy Verdun (2007). "Reforming Europe's stability and growth pact: Lessons from the American experience in macrobudgeting", Review of International Political Economy, 14 (5), 842-867.

Sbragia, Alberta (1992). "Thinking about the European Future: The uses of Comparison", in Alberta Sbragia (ed.), Euro-politics: Institutions and Policymaking in the New European Community, Washington, DC: The Brookings Institution: 257-291.

Schadler, Susan (ed.) (2005). Euro Adoption in Central and Eastern Europe: Opportunities and Challenges, Washington DC: International Monetary Fund. 
Scharpf, Fritz W. (1988). "The Joint-Decision Trap: Lessons from German Federalism and European Integration", Public Administration, 66(3): 239-78.

Schmitter, Philippe C. (1969). "Three Neo-functional Hypotheses about International Integration”, International Organization, 55: 47-80.

Schuknecht, Ludger et al. (2011). "The Stability and Growth Pact: Crisis and Reform", European Central Bank, Occasional Paper Series, 129.

Sheridan, Jerome (1996). "The Déjà Vu of EMU: Considerations for Europe from Nineteen Century America", Journal of Economic Issues, 30 (4): 1143-61.

Shiskin, John. (1974). "The Changing Business Cycle". New York Times, December 1.

Siaroff, Alan (2005). Comparing Political Regimes: A Thematic Introduction to Comparative Politics. Toronto: Broadview Press.

Sloman, John (2004). Economics. New York: Penguin Books.

Snaith, Holly (2011). "Building a new (constructivist) institutionalist conception of Multi-Level Governance within European monetary policy", paper presented at CEPSA conference: University of Vienna, October 27-29.

Spendzharova, Aneta (2013). "When 'Good Enough' Does Not Suffice: European Financial Regulation between Incrementalism and Radical Reform", paper presented at the 13th Biennial Conference of the European Union Studies Association in Baltimore, May 9-11, 2013.

Spinelli, A., Rossi, E. (1944 [1988]). The Ventotene Manifesto, The Altiero Spinelli Institute for Federal Studies, Pavia.

Spiro, Herbert J. (1974). "Interdependence: a Third Option between Sovereignty and Supranational Integration" in Ghita Ionescu (ed). "Between Sovereignty and Integration", New York-Toronto: John Wiley \& Sons: 143-164.

Statement of the Heads of State or Government of the Euro Area (2010). May 7.

Stein, Michael, and Lisa Turkewitsch (2009). "The relevance of the concept of multi-level governance for a comparative analysis of Canadian and American intergovernmental relations", in Henrik Enderlien, Sonja Walti, and Michael Zürn (eds.), Handbook on multi-level governance, London: Edward Elgar:184-200.

Stepan, Alfred (1999). "Federalism and Democracy: Beyond the U.S. Model", the Journal of Democracy, 10 (4): 19-34. 
Studlar, Donley T. (2010). "What Explains the Paradox of Tobacco Control under Federalism in the United States and Canada: Comparative Federalism versus Multi-level Governance", Publius 40: 389-411.

Studlar, Donley T., Kyle Christensen and Arnita Sitasari (2011). "Tobacco control in the EU-15: the role of member states and the European Union", Journal of European Public Policy, 18 (5): 728-745.

Swedish Parliament (2009). "EU Information", December 4. http://www.euupplysningen.se/Amnesomraden/EMU/Sverige-och-EMU (accessed February 13, 2014).

Szabo, Stephen (1992). The Diplomacy of German Unification, New York: St. Martin's Press.

Szász, André (1999). The Road to European Monetary Union, Basingstoke: Palgrave Macmillan.

Talani, Leila S. (2009). The future of EMU, Palgrave Macmillan, Basingstoke: Palgrave Macmillan.

Taylor, Paul (1975). "The Politics of the European Communities: The Confederal Phase". World Politics, xxvii (3): 336-60.

The euro crisis grounded (2010). The Economist, October 30.

The euro crisis spreading from Ireland to Iberia (2010). The Economist, November 27.

The Real Euro Danger (2010). Wall Street Journal, November 17.

Tietmeyer, Hans (1997). "Der Euro: ein entnationalisiertes Geld”, Auszuge aus Pressartikeln, December 12.

Tietmeyer Hans (1999). The Social Market Economy and Monetary Stability, London: Economica.

Tinbergen, Jan (1954). Centralization and Decentralization in Economic Policy, Amsterdam: North Holland.

Tömmel, Ingeborg and Amy Verdun (2009). Innovative Governance in the European Union: The Politics of Multilevel Policymaking, Boulder: Lynne Rienner.

Torres, Francisco, Amy Verdun, and Hubert Zimmermann (2006). EMU rules: the political and economic consequences of European monetary integration, Nomos: Baden-Baden.

Tranholm-Mikkelsen, J. (1991). "Neo-functionalism: Obstinate or Obsolete? A Reappraisal in the Light of the New Dynamism of the EC", Millennium, 20: 1-22. 
Treaty establishing the European Community (1957).

Treaty establishing the European Union (1992).

Trechsel, Alexander H. (2005). "How to federalize the European Union... and why bother", Journal of European Public Policy, 12(3): 401-418.

Triffin Robert (1958). «La monnaie et le Marché Commun - Politiques nationales et intégration régionale », Cahiers de l'Institut de Sciences Economiques Appliquées, No 74, December 1958, p. 1-17.

Trochim, William (2005). Research Methods: The Concise Knowledge Base, Cincinnati: Atomic Dog Publishers.

Tsoukalis, Loukas (1977). The Politics and Economics of European Monetary Integration, London: George Allen \& Unwin.

Tsoukalis, Loukas. (2003). What Kind of Europe, Oxford: Oxford University Press.

Ungerer, Horst (1997). A concise history of European Monetary integration: from EPU to EMU, Westport, CT: Quorum books.

Urdank, Albion M. (2012). "United States of Europe is on track”, Financial Times, July 16.

van Esch, F.A.W.J. (2002). "Why States Want EMU: Developing a Theory on National Preferences", in Amy Verdun (ed). The Euro: European Integration Theory and Economic and Monetary Union, Lanham MD: Rowman \& Littlefield: 125-144

Van Oudenaren, John (2005). Uniting Europe. Lanham, MD: Rowman and Littlefield.

Van Tichelen, John (1981). "Souvenirs de la Négociation du Traité de Rome", Studia Diplomatica, 34 (1-4).

van Ypersele, Jacques and Kœune, J.C. (1985). The European Monetary System, Cambridge: Woodhead-Faulkner.

Verdun, Amy (1998). "The Role of the Delors Committee in the Creation of EMU: An Epistemic Community?”, European University Institute, Working Paper RSC, 98/44.

Verdun, Amy (2002). "The Euro: European Integration Theory and Economic and Monetary Union" in Amy Verdun (ed). The Euro: European Integration Theory and Economic and Monetary Union, Lanham MD: Rowman \& Littlefield: 17-28. 
Verdun, Amy (2010). "Economic and Monetary Union", in Michelle Cini and Solórzano Borragán (eds). European Union Politics, New York:Oxford University Press: 324-339.

Verdun, Amy (2012). "The Euro Has a Future” in Zimmermann Hubert and Andreas Dür (eds.), Key Controversies in European Integration, Houndmills, Basingstoke: Palgrave Macmillan: 113-120.

Vila Maior, Paulo (2007). “A Theoretical Approach of Economic and Monetary Union: Does Practice Vindicate Liberal Intergovernmentalism?", Paper presented at the UACES Conference, September 3-5, Portsmouth UK.

Vilpišauskas, Ramūnas and Vytautas Kuokštis (2013). "National responses to the financial and economic crisis: how relevant is the experience of the Baltic States to the Southern EU members?", paper presented at the 13th Biennial Conference of the European Union Studies Association in Baltimore, May 9-11, 2013.

Viner, Jacob (1950). The Customs Union Issue, New York: Carnegie Endowment for International Peace.

von Hagen, Jürgen (2013). "Through Crises to EMU: Perspectives for Fiscal Union and Political Union”, in Ludger Künhhardt (ed.), Crises in European integration: challenge and response, 1945-2005, Berghahn Books: New York/Oxford: 61-77.

von Hagen, Jürgen and Christopher J. Waller (2000). Regional aspects of monetary policy in Europe, Boston: Kluwer Academic.

Wallace William, Helen Wallace and Mark Pollack (2005). Policy-Making in the European Union, Oxford: Oxford University Press.

Waltz, Kenneth (1979). Theory of International Politics, New York: McGraw Hill.

Warleigh, Alex (1998). "Better the Devil You Know? Synthetic and Confederal Understandings of European Unification”, West European Politics, 21(3).

Watts, Ronald L. (1998). "Federalism, Federal Political Systems, and Federation", Annual Review of Political Science, 1: 117-37.

Watts, Ronald L. (1999). "The Theoretical and Practical Implications of Asymmetrical Federalism”, in Robert Agranoff (ed.), Accommodating Diversity: Asymmetry in Federal States, Baden-Baden: Nomos Verlagsgesellschaft: 24-42.

Weidmann, Jens (2012). "Monetary policy is no panacea for Europe's ills", Financial Times, July 5. 
Weiler, Joseph (1999). The Constitution of Europe: Do the Emperor has New Clothes?, New York: Cambridge University Press.

Weingast, Barry (1995). "The Economic role of Political Institutions: Market Preserving Federalism and Economic Development”, Journal of Law, Economics and Organization, 11: $1-31$.

Wendt, Alex (1999). Social Theory of International Politics, Cambridge: Cambridge University Press.

Wessels, Wolfang (1997). "An Ever Closer Fusion? A Dynamic Macropolitical View on Integration Processes”, Journal of Common Market Studies, 35(2): 267-99.

Wheatcroft, Patience (2010). "Europe's Bad Boys Must Get Clubbable", The Wall Street Journal, October 19.

Wiener, Antje, Thomas Diez (2004). European Integration Theory, Oxford: Oxford University Press.

Wolf, Dieter (2002). "Neofunctionalism and Intergovernmentalism Amalgamated: The Case of EMU”, in Verdun (ed). The Euro: European Integration Theory and Economic and Monetary Union, Lanham MD: Rowman \& Littlefield: 29-50.

Zelikow, Philip, and Condoleezza Rice (1995). Germany United and Europe Transformed: A Study in Statecraft, Cambridge: Harvard University Press.

Zimmerman, Joseph F. (2011). Horizontal Federalism, SUNY Press: Albany, NY. 


\section{Appendix}

List of people interviewed and the year of the interview.

Dr. Federiga Bindi - Chair in European Political Integration, University of Rome Tor Vergata (2011).

Dr. Astrid B. Boening - Associate Director of European Union Center, Department of International Studies, University of Miami (2009).

Dr. Laurie Buonanno - Professor, Political Science Department, State University of New York at Buffalo (2013).

Dr. Patrick Crowley - Professor of economics at Texas A\&M University in Corpus Christi (2010).

Dr. Michelle Chang - Professor in European Politics, College of Europe (2013)

Dr. Kenneth Dyson - Research Professor, School of European Studies, Cardiff University (2011).

Dr. Richard W. Fisher - President of the Federal Reserve Bank of Dallas (2010)

Dr. Vitor Gaspar - Director-general for research at the European Central Bank (2010).

Dr. Gabriel Glöcker - Deputy Head of EU Institutions and For a Division, European Central Bank (2013).

Dr. Erik Jones - Professor of European Studies, John Hopkins University (2011).

Dr. Robert Leonardi - Professor in the Government Department, London School of Economics (2010).

Dr. David Mayes - Professor of Finance in the Business School, University of Auckland (2010).

Dr. Arne Niemann - Professor of International Politics, Johannes Gutenberg Universitat Mainz (2013).

Dr. Lucia Quaglia - Professor at the Department of Politics, University of York (2013).

Dr. Claudio M. Radaelli - Professor of Political Science, University of Exeter (2013).

Dr. Miguel Otero-Iglesias - Visiting Research Fellow at the Centre for International Studies, London School of Economics and Political Science (2013). 
Dr. Taavi Rõivas - Chairman of the Finance Committee in Estonia (2010).

Dr. Bernhard Schloh - Professor emeritus, Vrije Universiteit Brussel (2012).

Dr. Aneta Spendzharova - Assistant Professor, Department of Political Science, Maastricht University (2012).

Dr. Amy Verdun - Professor of Political Science, University of Victoria (2011).

Dr. Ramunas Vilpisauskas - Director of the Institute of International Relations and Political Science, Vilnius University (2011).

Dr. Phil Wilkin - Bibliographer of the Archive of European Integration, University of Pittsburgh (2010).

Dr. Carol S. Weissert - Professor in the Department of Political Science, Florida State University (2009). 